\title{
Sieglinde Holzheid
}

\section{Die Nominalkomposita in der lliasübersetzung von N. I. Gnedič}

Verlag Otto Sagner München · Berlin · Washington D.C.

Digitalisiert im Rahmen der Kooperation mit dem DFG-Projekt „Digi20“

der Bayerischen Staatsbibliothek, München. OCR-Bearbeitung und Erstellung des eBooks durch den Verlag Otto Sagner:

http://verlag.kubon-sagner.de

( $)$ bei Verlag Otto Sagner. Eine Verwertung oder Weitergabe der Texte und Abbildungen, insbesondere durch Vervielfältigung, ist ohne vorherige schriftliche Genehmigung des Verlages unzulässig. 


\section{S L A VIST IS C HE BEITRA E}

Unter Mitwirkung von M. Braun, Göttingen $\cdot †$ P. Diels, München $\cdot J$. Holthusen, Bochum - E. Koschmieder, München - W. Lettenbauer, Freiburg/Br. J. Matl, Graz F. W. Neumann, Mainz - K.-H. Pollok, Regensburg - L. Sadnik-Aitzetmüller, Saarbrüdken $\cdot$ J. Schütz, Erlangen

HERAUSGEGEBEN VON A. SCHMAUS, MUNCHEN

Technische Redaktion: P. Rehder, München

Band 19 
SIEGLINDE HOLZHEID

\section{DIE NOMINALKOMPOSITA IN DER ILIASÜBERSETZUNG VON N. I. GNEDIČ}

VERLAG OTTO SAGNER - MÜNCHEN 1969

$P(63) 3651$ 


\section{Bayerische}

Staatsbiblio' ak

Minchen

Copyright by Verlag Otto Sagner, München 1969

Abteilung der $\mathrm{Fa}$. Kubon \& Sagner, München

Druck: Fa. W. u. I. M. Salzer

8 München 2. Schleißheimer Straße 20 
ME I N E R M U T T E R 
Hol

13 for

toje 1. 10 ond 30 s

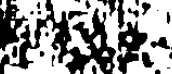

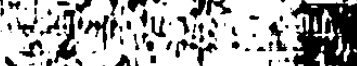

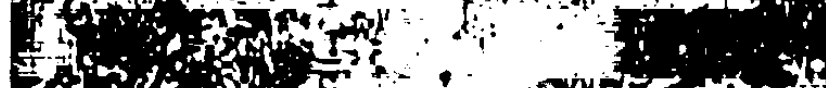

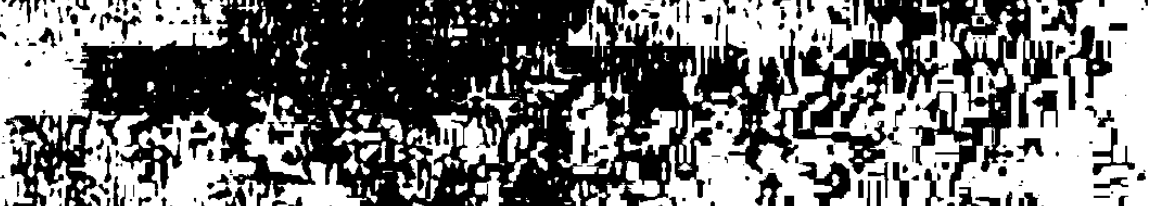

sing (n) fol

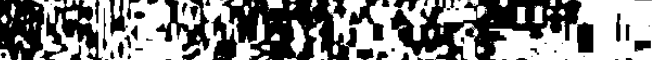
Af 10.10

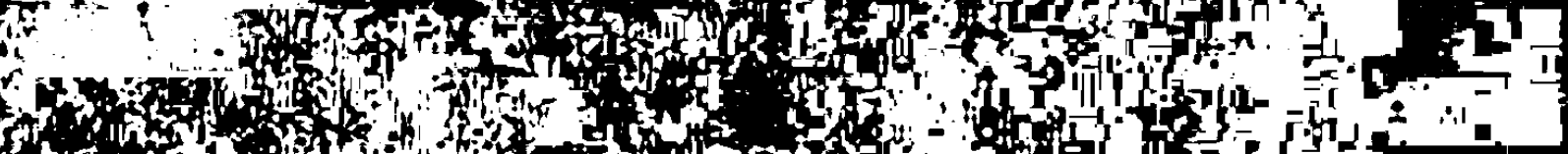

$\therefore$ ar

(4)

(1) If ats

ition

(5)

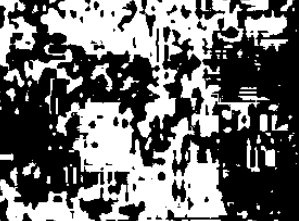

and

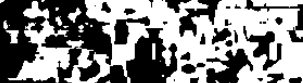

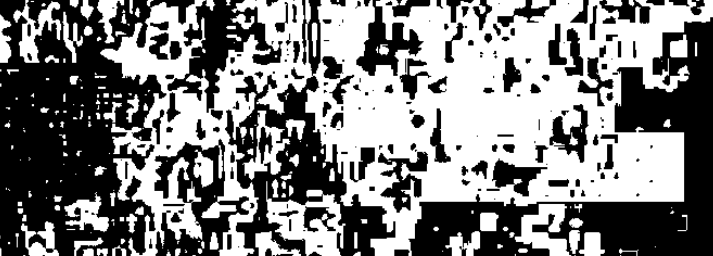

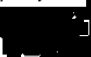

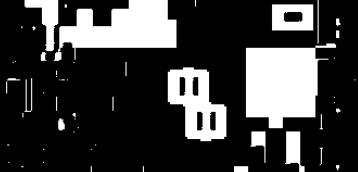

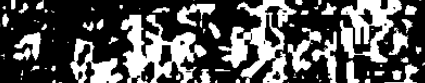
1. (1)

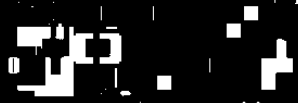

我

\section{Wh in}

$\Rightarrow$ ita

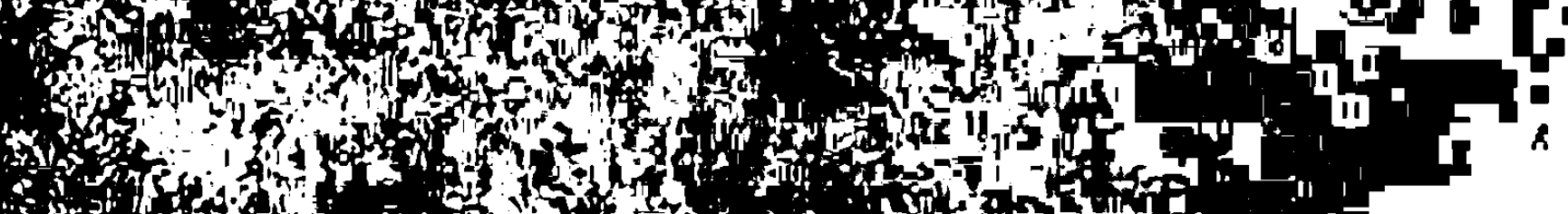

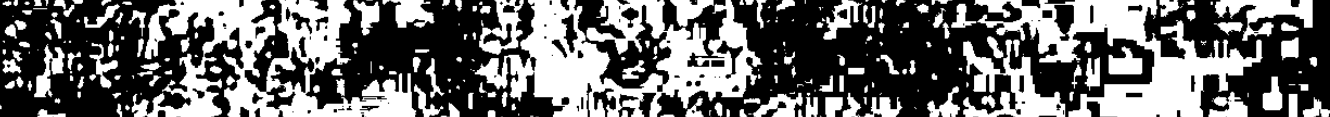

ofpt (1) 4 10.

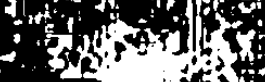
8

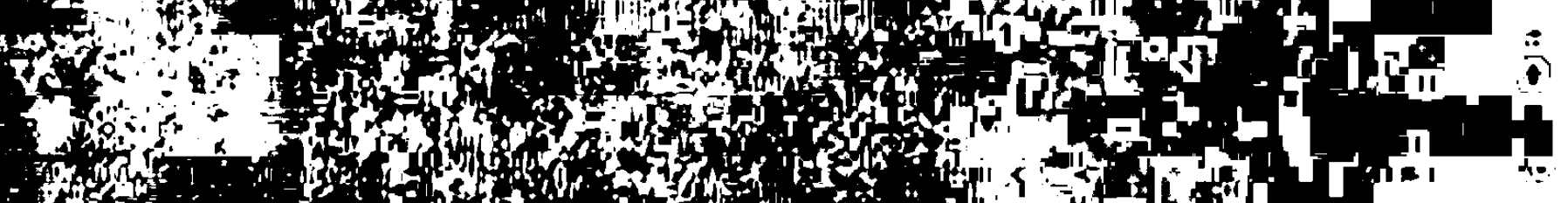
ninging sing

H.

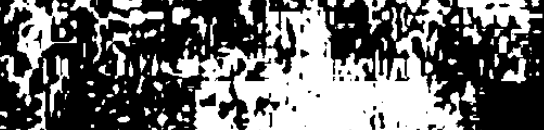

$$
\text { if }
$$

f

$$
\begin{aligned}
& \text { tol }
\end{aligned}
$$

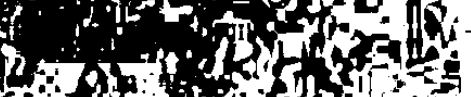

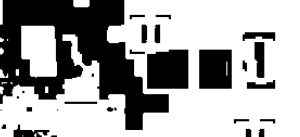

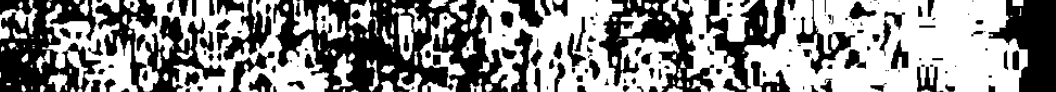
(1) Nitis: 
Verzeichnis der benutzten Quelien und Literatur, sowie der Abkürzungen

Einleitung

A. Material

Die von Gnedit gebrauchten Nominalkomposita in alphabetischer Reihenfolge mit den entsprechenden Ausdrücken bei Homer

B. Auswertung des Materials

I. Gnedid Neigung zum Variieren

62

II. Einteilung der Nominalkomposita in

1. Nominalkomposita, die vor Gnedil belegt sind

2. Neubildungen von Gnedid

a) als Lehnübersetzungen

b) als Neubildungen ohne Vorbild im Original

77

c) als Varianten zu älteren Komposita

79

3. Fragliche Urheberschaft bei einigen Komposita

81

4. EinfluB von $\mathrm{VOB}$

83

III. Art der Komposition

85

IV. Einfluß des Kirchenslaviscinen 88

v. Schlubwort

90 


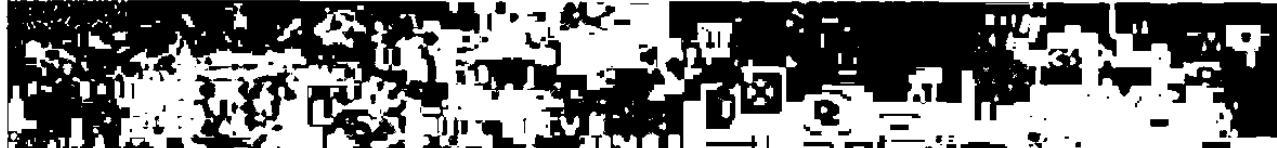

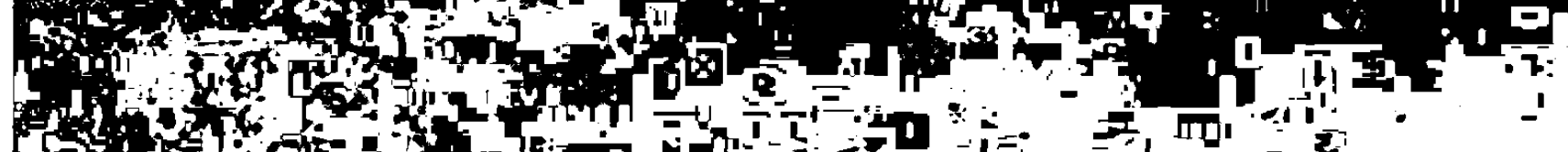

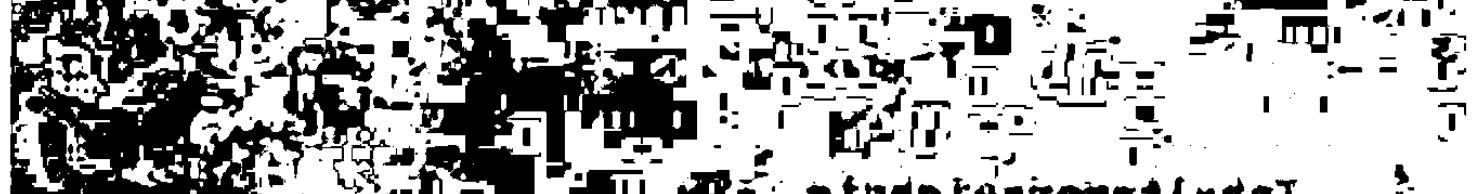

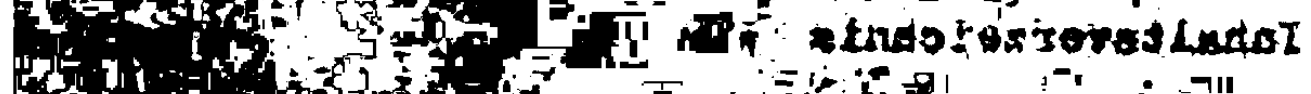

Lox

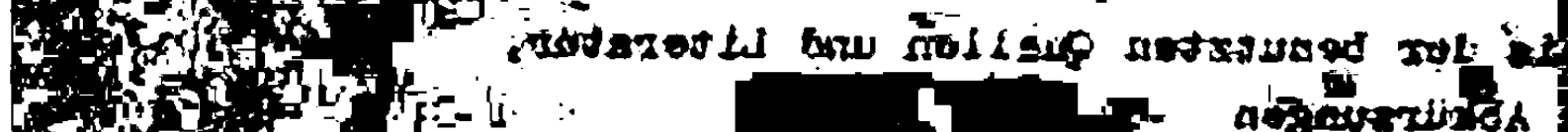

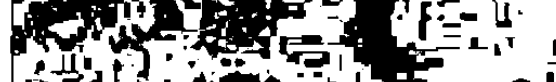

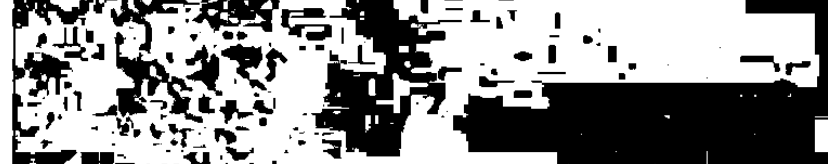

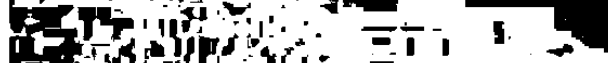

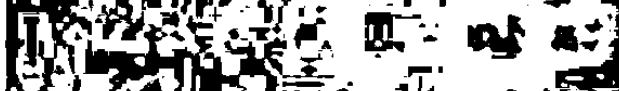

(1)

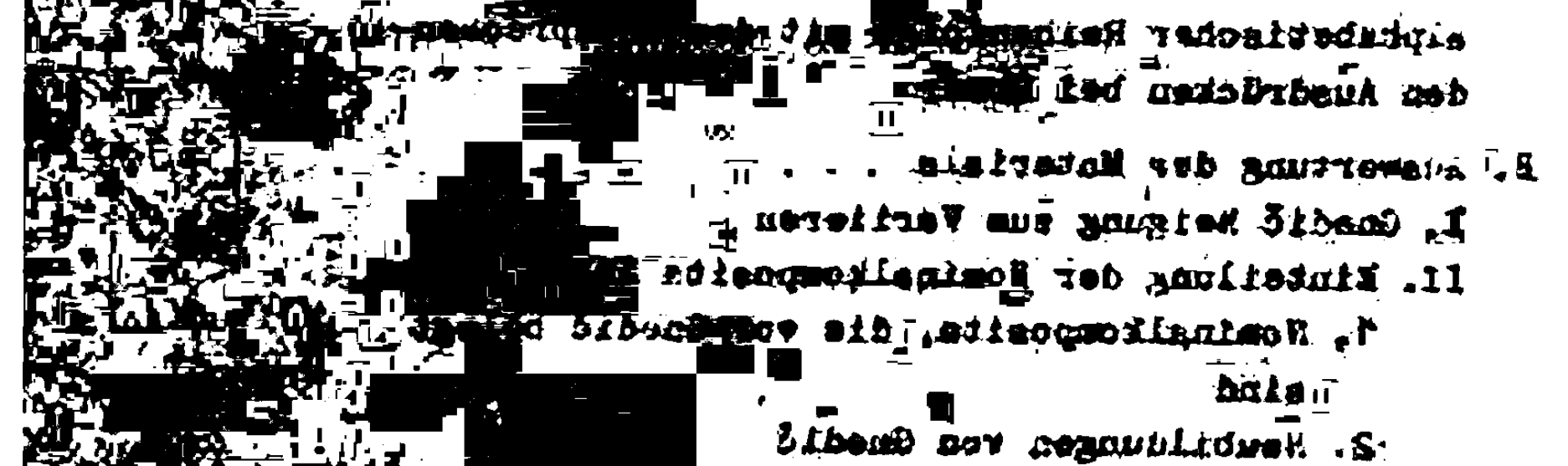

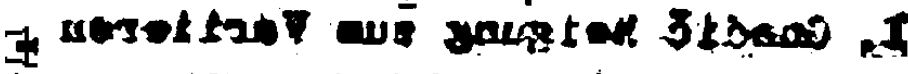

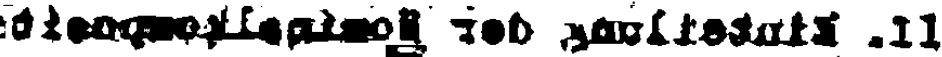

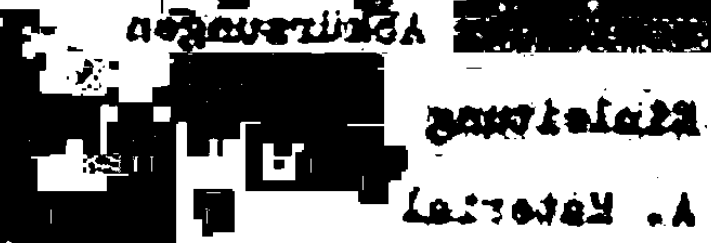

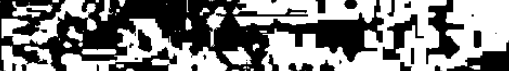

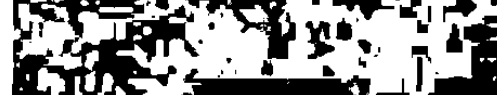

ats

11

Q

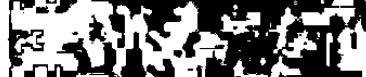

ond

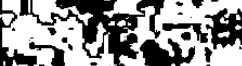

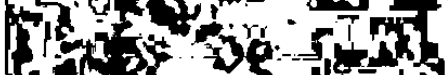

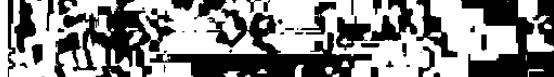

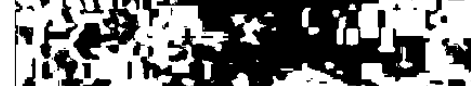

(f)

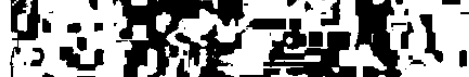

$\therefore$.

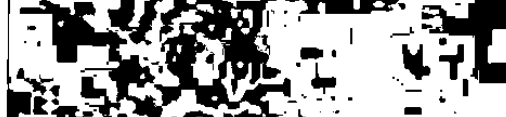

tots

pit

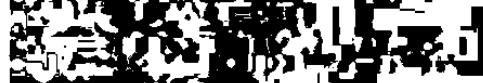

fint
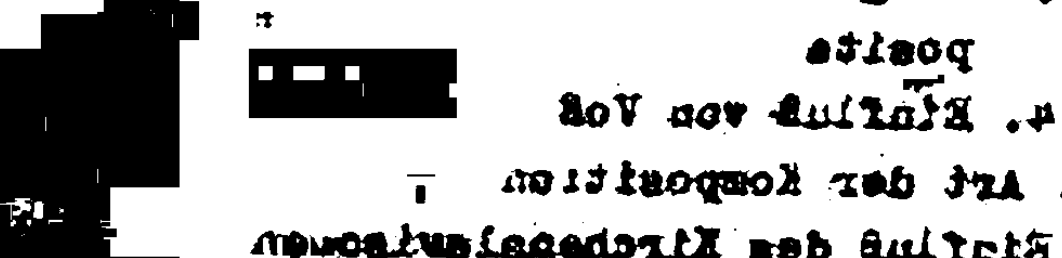

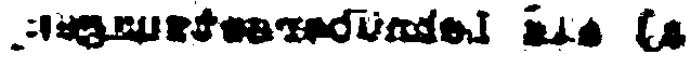

of ando incosolloweh als (o

- traxis

A.

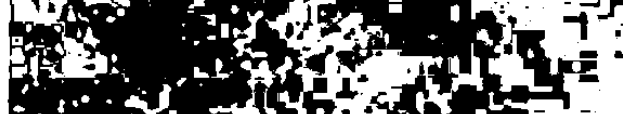

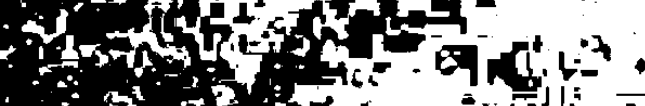

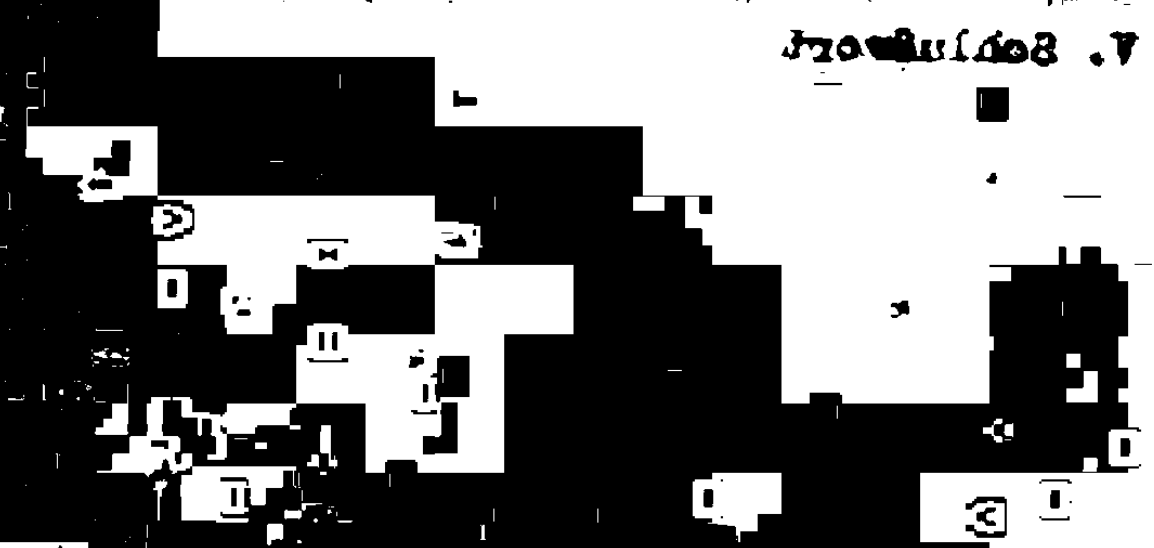

- sostbagaod ato the . III

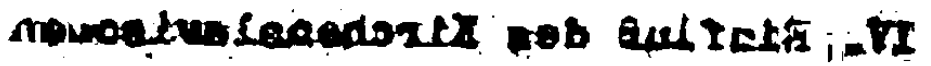
int

in 2

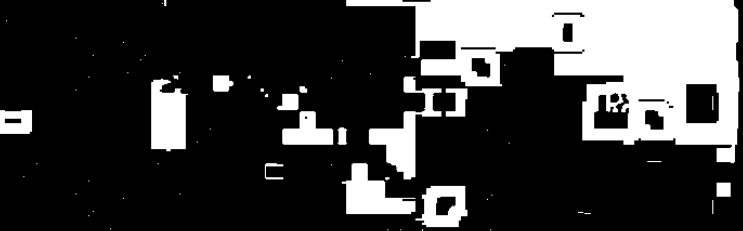


Verzeichnis der benutzten quellen und Literatur, sowie der Abkürzungen

Afanas'ev, A.N.:

Narodny ja russkija legendy, Moskau 1914

K.Danilov $=$ Danilov, Kir\$a:

Drevnija rossijskija stichotvorenija, Moskau 1818

Benseler, G.E. :

Griechisch-deutsches Schulwörterbuch, Leipzig 1896

Chapman, George:

Homer's Iliad and Odyssey, Lond on 1892

Deržavin, G.R.:

Stichotvorenija, Biblioteka poeta, Moskau-Ieningrad 1963

Dickenmann = Dickenmann, E.:

Untersuchungen über die Nominalkomposition im Russischen, I, Leipzig 1934

Fénelon:

Les Aventures de Télémaque, Paris 1930

Gnedil, N.I.:

Stichotvorenija, Biblioteka poeta, Leningrad 1956

Gnedið, N.I.:

Iliada, Ausgabe Academia, Moskau-Ieningrad 1935

Golovackij = Golovackij, I.:

Narodnyja pesni Galickoj i Ugorskoj Rusi, Moskau 1878

Grammatika russkogo jazyka (AN SSSR),

Tom I: Fonetika i morfologija, Moskau 1953

Beym $M=$ Heym (Gejm), I. :

Novyj rossijsko-francuzsko-nemeckij slovar', Moskau 1802

Heym R = Heym (Gejm), I. :

Polnjj Rossijsko-nemeckij slovar' po bol'šomu slovarju Rossijskoj Akademii sotinjonnj, Riga 1801

Heym $S=$ Heym (Gejm), I.:

Polnyj Rossijsko-francuzsko-nemeckij slovar', Sanktpeterburg 1826 
Hilferding $=$ Hilferding (Gil'ferding), $A_{0}:$

Onežskija Byliny, Sbornik otdel.russkago jazyka i slovesnosti Imp.Akademii Nauk, Bd.59-61, Sanktpeterburg 1894-1900 Hölterhof (Geltergof) s.u.Ross.Cell.

Homerici Ilias,

ed. Guilelmus Dindorf, Leipzig 1939

Hüttl-Worth = Hüttl-Worth, G.:

Die Bereicherung des russiscnen ilortschatzes im XVIII.Jahrhundert, Wien 1956

Jagić, V.:

Die slavischen Composita in ihrem sprachgeschichtlichen Auftreten, ASP XX, 519 ff, XXI $28 \mathrm{ff}$.

Jegunov = Jegunov, A.N.:

Gomer $v$ russkich perevodach XVIII-XIX vekov, Al SSSR, lioskauLeningrad 1964

Kaegi, A.:

Autenrieths Scrulwörterbuch $z u$ den Homerischen Gedichten, Leipzig-Berlin 1904

Kukulevið, A..:

Iliada $v$ perevode il.I.Gnedið̌, uXonyje zapiski Leningradskogo gosudarstvennogo universiteta $\mathrm{Nr} .33$, serija filologiðeskich nauk, vyp.2, Leningrad 1930

Leskien, A.:

Grammatik der altbulgarischen (altkirchenslavischen) Sprache, Heidelberg 1919

Lettenbauer, H.:

Russische Literaturgeschichte, :iesbaden 1958

Bienge :

Enzyklopädisches Wörterbuch der griechiscnen und deutschen Sprache, Teil I, Griechisch-deutsch, Berlin-Schöneberg 1951 Miklosich $=$ Miklosich, F.:

Lexicon palaeoslovenico-graeco-latinum, Wien 1862-1865

Nordstet $=$

Rossijskij s nemeckim i francuzskim perevodami slovar' soð̌i- 
njonny j... Ivanom Nordstet om, Sanktpeterburg 1780-1782

Pawlowsky, I.:

Russisch-Deutsches Wörterbuch, Riga 1900

Polik. = Polikarpov, F.:

Leksikon trejazy đajj, sirex' Retenij slavenskich, jellinogređeskich $i$ latinskich sokroviłče, Moskau 1704

Ross.Cell. = Rossijskoj Cellarius

ili etimologiCeskoj rossijskoj leksikon kupno s pribavlenijem inostrannych $v$ rossijskom jazyke $v$ upotreblenije prinjatych slov...izd.M. Franciskom Geltergofom, Moskau 1771

Rybnikov $=$

Pesni sobrannyja P.iN.Rybnikovym, izd.2-e pod red.A.J.Gruzinskago, Moskau 1909-1910

Slov.Ak.Nauk =

Slovar' sovremennogo russkogo liternaturnogo jazyka, AN SSSR, A-T, Moskau 1950-1963

Slovar' Akademii Rossijskoj,

Sanktpeterburg 1789-1794

Slov.Ak.Ross. =

Slovar' Akademii Rossijskoj, po azbuǩnomu porjadku raspoloZennyj, Sanktpeterburg 1806-1822

Sobolevskij $=$

Velikorusskija narodnya pesni, izd.prof.A.I.Sobolevskim, Sanktpeterburg 1895-1902

Sokolor = Sokolov:

Obłtij cerkovno-slavjano-rossijskoj slovar', Sanktpeterburg 1834

Srez. = Sreznevskij, I.I.:

Materialy dlja slovarja drevnerusskogo jazjka po pis'mennym pamjatnikam, Sanktpeterburg 1893

Tichanov, P.:

Nikolaj Ivanovil Gnedil, Neskol'ko dannych dlja jego biografii po neizdannym istolnikam, izd.vtorogo otdelenija Imperatorskoj Akademii Nauk, Sanktpeterburg 1884 
Tolstoj, I.I.:

Gnedid kak perevodXik Iliady, $v$ knige Iliada, izd.Academia, Moskau-Ieningrad 1935

Tschižewskij (Čyževßkgj), D.:

Literarische Lesefrüchte VIII Nr.69 ( $\mathrm{Zu}$ den Komposita in der Sprache Trediakovakijs), ZSP XVII S.114 ff.

Vasmer, M.:

Russisches etymologisches Wörterbuch, Heidelberg 1953

Vejsmannov s.u.WeiBmann

Vinogradov, V.V.:

Russkij jazyk, Moskau-Leningrad 1947

Vondrák W.:

Vergleichende Slavische Grammatik, Göttingen 1924

VOB, J.H.:

Homers Ilias, Text der ersten Ausgabe, Neudruck Leipzig 1938

WeiBmann = Vejsmannov:

Nemecko-latinskij i russkij leksikon kupno s pervymi nacaiami russkago jazyka, sanktpe terburg 1731

NB = Nominalkompositum 
Zur Beachtung:

GnediC wird nach der Ausgabe "N.I.GnediC, Stichotvorenija, Biblioteka poeta, Leningrad 1956" zitiert.

Die deutsche Bedeutung wird nur ausnahmsweise angegeben.

Wenn nicht längere Stellen zu zitieren sind, werden die Wörter meist im Nominativ ange führt.

Aus technischen Gründen wurde die Schreibung der kirchenslavischen und altrussischen Wörter im allgemeinen der modernen Orthographie angepaßt.

Obwobl das Wörterbuch von Sokolov "Obకtij cerkovno-slavjanorossijskoj slovar' erst 1834 erschienen ist, wurde es als Beleg für Nominalkomposita, die schon vor Gnedil gebräuchlich waren, herangezogen, da die Wörterbücher hinter dem tatsächlichen Sprachgebrauch normalerweise um einige Jahre zurück sind.

Protz wiederholter Bemühungen ist es nicht gelungen, einige Werke, die für die Bearbeitung des Themas von Interesse gewesen wären, über die Pernleihe zu beschaffen. 


\section{Einleitung}

Nikolaj Ivanovil Gneail (1784 - 1833) wurde, einer Kosakenfamilie entstammend, in Poltava geboren. Im Alter von neun Jahren kam er dort auf die Schule, die slovenskaja seminarija. Schon früh zeigte er besonderes Talent für alte Sprachen, schrieb Verse und spielte gern Theater. Später ermöglichte ihm ein Gönner den Ubertritt in das nach dem Muster der polnischen Jesuitenschulen aufgebaute Kollegium von Char'kov, das er 1800 absolvierte. Dann begab er sich nach Moskau, wo er zunächst in die Blagorodnyj Universitetskij pansion eintrat, bevor er an der Universitet studierte. Bedeutungsvoll wurden für ihn die Vorlesungen von Professor P. A.Sochackij über griechische und römische Literatur, die in inm ernstes Interesse an der antiken Dichtung weckten. Seine Neigung zum Theater pflegte er weiter, indem er an Auffürungen mitwirkte, z.B.spielte er in Schillers Fiesco, den er auch übersetzte, den Verrina.

Da Gnedil mittellos war, gab er 1802 das Studium auf und suchte sich eine Stelle. Er begab sich nach Petersburg, wo er sich als Schreiber im Kultusministerium kümmerlich durchschlug. Seine Freizeit widmete er der Literatur, betütigte sich auch als tbersetzer. Die tbertragung von Schillers Fiesco brachte ihm Runm ein. Er versuchte sich, allerdings ohne Erfolg, im Roman, schrieb eine Menge Gedichte, wirkte als Theaterkritiker und übersetzüe weiterhin für das Theater, u.a. Shakespeares Hamlet und King Lear und Voltaires Tancrède. 1) Bleibenden Ruhm trugen Gnedil nicht seine Gedichte ein, sondern seine Iliasübersetzung, an der er von 1807 an arbeitete und die 1829 im Druck erschien. 1809 wurde er der materiellen Sorgen überhoben, da er eine stelle als Bibliothekar und eine Dienstwohnung bei der Offentlichen Bibliothek in Petersburg erhielt, an der auch $\mathrm{Krylov}$ wirkte. Dort hatte er alte Hand-

1.Vgl.P.Tichanov, Nikolaj Ivanovid Gnedid, Neskol'ko dannjch dlja jego biografii, Sanktpeterburg 1884, s.1 ff; I.N.Medvedeva, Einleitung zu Gnedid stichotvorenija, Biblioteka poeta, Leningrad 1956, S.5 ff. 
schriften und Bücher durchzusehen. Man darf wohl annebmen, daB er dabei manche Anregung für die sprachliche Gestaltung seiner Iliasübersetzung empfing.

Von groBer Bedeutung wurde für ibn der Verkehr mit seinem Vorgesetzten Olenin, der neben der Offentlichen Bibliothek auch die Akademie der Künste leitete. Dieser war ein vorzüglicher Kenner der Antike. Inm verdankte Gnedid für seine Ubersetzung wichtige sachliche Erklärungen und Hinweise. 1) Auf Gnedid Schaffen waren ferner von EinfluB einerseits seine Beziehungen zur Beseda ljubitelej russkogo slova, deren bedeutendste Vertreter Siłkov, Deržavin und Krylov waren. ${ }^{2}{ }^{2}$ Sie standen bekanntlich im Gegensatz zu den in der Gesellschaft Arzamas zusammengeschlossenen Karamzinisten. Siłkov und seine Anhänger lehnten es ab, die russiscne sprache nach auslïndischen Vorbildern zu formen.

Andererseits ist aber auch Gnedic Freundschaft mit Batjuskov von Bedeutung, mit dem er in lebhaftem Gedankenaustausch über Probleme der Dichtkunst stand und Fragen der Ubersetzung Homers diskutierte. 3)

Ursprünglich wollte Gnedix mit seiner Iliasübersetzung die Ubertragung der ersten sechs Gesänge von Kostrov weiterführen, die sich großer Beliebtheit erfreute. Er fing daher mit dem 7. Gesang an. Kostrovs Ubersetzung war in Alexandrinern abgefaßt. Auch Gnedic bediente sich zunächst, der allgemeinen damaligen Mode folgend, des Alexandriners, gab aber dieses Wetrum 1811 auf, da es ihm für die tbersetzung von Hexametern nicht geeignet erschien. ther seinen EntschluB schrieb er 1813 in "Xtenija v Besede ljubitelej russkogo slova": "Давно чувствур невыгоды стиха александрииского для перевода древних позтов...ясно видимке из того уке, что 17 слогов зкзаметра вместить в 12 aлександрийского стиха нет возмохности, не лиша его или хивописншх зпитетов, или силь, или вообще ха-

1.Vgl.A.Kukulevic, Iliada v perevode N.I.Gnediða, Ieningrad 1939, S.32 ff; Medvedeva a.a.O.S.20 ff; A.N.Jegunov, Gomer $v$ russkich perevodach XVIII-XIX vekov, Moskau-Leningrad 1964, S.189 ff.

2.Vgl.Kukulevid a.a.0.S.45 ff; hiedvedeva a.a.0.S.17 ff; Jegunov $S .164$ ff.

3.VgI.Medvedeva a.a.0.S.13 ff; Jegunov S.169 ff. 
рактерв древнен поззии, чвсто разрушаемого маленшим изменением оборота, необходимкм для рифмы. Таким образом, нет возмохности в переводе стихами александринскими удовлетворить хеланир просвещенных читателей...знакомых с язиком древних и дорого денящих священные красоты древнеи поззии." 1) Lit der Wahl des Hexameters steht Gnedic in Einklang mit den Theorien Radił̌evs. Ferner setzte sich u.a. Unterrichtsminister S.S.Uvarov, ein groBer Kenner und Iiebhaber der antiken Poesie, nachdrücklich für den Hexameter ein. 2)

Jedem, der Homer liest, fallen die vielen Nominalkomposita

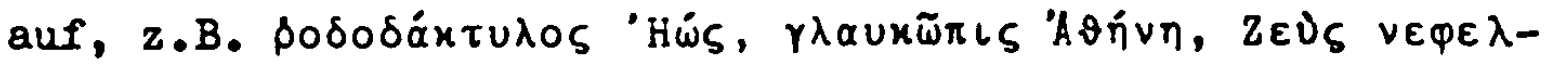
$\eta \gamma \varepsilon \rho \varepsilon \tau_{\zeta}$. GnediC hat diese zusammengesetzten Epitheta häufig durch NK übersetzt.

Zur Geschichte der sog. dvuchsostavayje epitety sei nur kurz an folgendes erinnert: Die Forschung hat nachgewiesen, daB die baltoslavische Gruppe von Haus aus von der Komposition nur geringen Gebrauch macht. 3) Es gibt nur wenige NK, die gemeinslavisch sind, z.B. господь, медведь, человек. ${ }^{4)}$

Wir haben zwar schon in ältester Zeit eine Menge slavischer Fersonennamen wiе Преслав, Богдан, Всеволод, diese stimmen

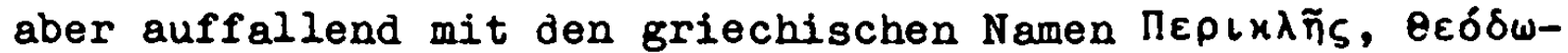
pos, Пoגuxpátns überein. Man kann nicht nachweisen, daB die slavischen Namen direkt aus dem Indogermanischen ererbt sind. Bei den ältesten altkirchenslavischen Ubersetzern zeigt sich eine gewisse Abneigung gegen Komposita, so wurde

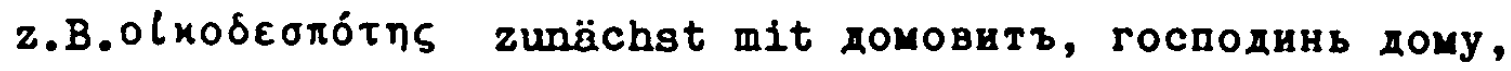

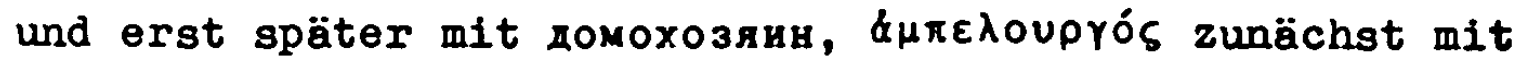

1.Zit.nach Medvedeva a.a.0.S.25.

2.Näheres zur Polemik über Fragen des Metrums vor allem bei Jegunov $\mathrm{S} .175 \mathrm{ff}$.

Anders wollte Kapnist das Problem gelöst wissen. Er schlug vor, entike Epen mit dem russischen Bylinenvers zu übersetzen. Er selbst übertrug einige Verse der Ilias auf diese Weise, aber sein Experiment hatte wenlg Erfolg, vgl.Tichanov a.a.0.S.12, Medvedeva a.a.0.S.25, Jegunov S.177.

3. Vgl.vor allem E.Dickenmann, Untersuchungen über die Nominalkomposition im Russischen, I, Leipzig 1934, S.14ff.

4.Vgl.V.Jagic, Die slavischen Composita in ihrem sprachgeschichtlichen Auftreten, ASP Bd.20, 5.535 ff. 
Simplex винарь, erst später mit виноградьникъ, Һшолоцєіv mit хивити, erst später mit хивотворити übersetzt. Doch setzten sich die Komposita in der tbersetzungsliteratur immer mebr durch, man denke nur an die vielen Bildungen mit блaro-, die griech.عú- wiedergeben, z.B. благословить, благодать, благообразнын.

Bemerkenswert ist, daB scnon in der altkirchenslavisc:een tbersetzung der Evangelien und des Psalters einige griechische Simplicia durch NK wiedergegeben sind. 1)

In der altrussischen weltlichen Literatur sind die NK zunächst ebenfalls recht selten. 2) Im Igorlied kommen z.B. abgesehen von Eigennamen nur vor: богородица, песнотворец, иноходец, тресветлый, златоверхй, златокованныи, многовои, полдень, полночь. Aber auch im Russischen breitete sich die Komposition rasch aus, und zwar wurden sowohl in der gehobenen Sprache als auch in der Volksdichtung die zusammengesetzten Adjektiva weit produktiver als die Substantiva. In den Bylinen finden sich vorwiegend epitheta ornantia, die stïndig wiederkehren, z.в. белокаменныи, белодубовыи, чернобархатный, чернобровыи, кособрюхй, златорогй, стольнекиевскии U.v.а. Großer Beliebtheit erfreuen sich in der Volksdichtung daneben die Asyndeta, z.В. ножище-кинжалище, сила-рать, пука-рыба, птица-сокол, красота-лепота, (ехали) поры-времечка и.а. Hie Tschižewskij in seinem Aufsatz "Zu den Komposita in der Sprache Trediakovskijs", ZSP XVII S.114 ff, ausführt, waren die NK besonders im 15.Jahrh.sehr beliebt, vor allem bei Pachomij Logofet und Jepifanij Premudryj, die viele Neubildungen schufen, z.В. многомутныи, горопленның, волкохищный. Tschizewskij weist ferner nach, daß sich die Komposita dann in der Barockdichtung gröBter Beliebtheit erfreuten. Namentlich Sime on Polockijs Vecerja dušmaja ist eine Fundgrube für Hortschöpfungen, z.В. огнеоблачныи, кораблеломительныи, хладнотвердый.

Auch Deržavin machte, zum Teil unter dem Einfluß der deut-

1.Vgl.Jagic a.a.0.S.537 ff.

2.Derselbe, ASP Bd.21, S. 28 ff. 
schen Literatur, reichlich von der Komposition Gebrauch. Er bildete zahlreiche neue Zusammensetzungen, z.В, густокудрявыи, далекозвонкии, чернопенныи, широкошумный. 1)

Zuvor hatte Trediakovskij in seiner the rsetzung von Fenelons Télémaque eine Reihe neuer Komposita geschaffen. Das ist umso bemerkenswerter, als er im französischen Original dafür keine Vorbilder fand. Die NK waren offenbar so beliebt, daß er im Gegensatz zum französischen Text nicht nur viele schon gebräuchliche Zusammensetzungen verwendete, sondern auch neue bildete, z.В. пенороднни, дукометныи, густоветвенныи, щедродушие.

Wenn schon Trediakovskij ohne Vorbild im französischen Originaltext sich so reichlich des Stilmittels der Nominalkomposita bedient, dann ist es nicht verwunderlich, daß sich bei Gnedið in seiner Iliasübersetzung Zusammensetzungen in Hülle und Fülle finden.

1.Vgl.Kukulevit a.a.0.S.10 ff; Jegunov S.167. 


\section{A. Material}

Die von Gnedid gebrauchten Nominalkomposita in alphabetischer Reihenfolge mit den entsprechenden Ausdrücken bei Homer

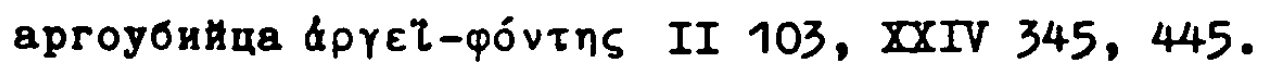

багряногнедн (конь) фогиц६ XXIII 454.

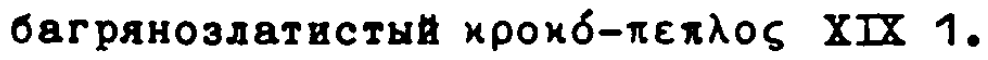

бегоборед: обнчная мзда то ногам бегоборцев ӓ $\tau \varepsilon$ поббіv

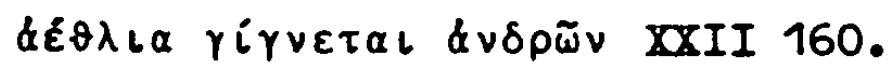

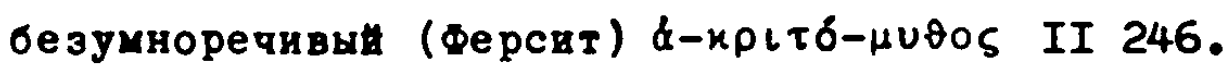

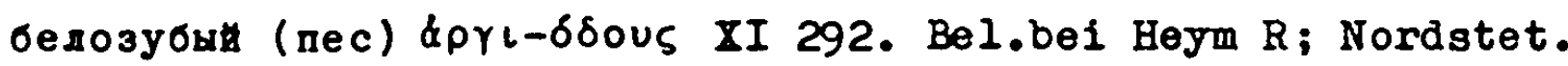

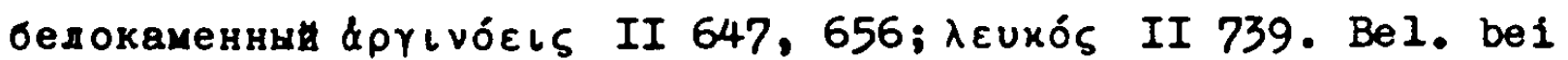

Kirşa Danilov, S.38, 41, 49 u.a.; Hilferding S.19, 22, 23,

43 u.v.a.; Sobolevskij I Nr.2,S.9, Nr.19,S.43 u.a. белокдыкий (вепрь) \&рүь-о́бочs IX 539, XXIII 32.

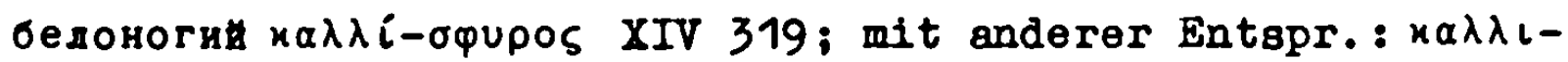
rápnos XI 224. Bel.bei Nordstet; Heym R.

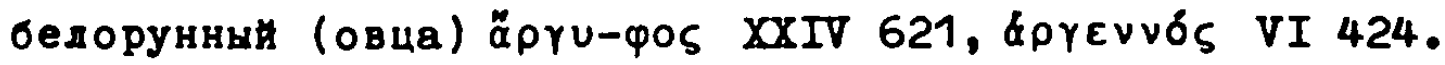
беспояснодоспешны "gürtellos gerüstet", "mit Rüstung ohne

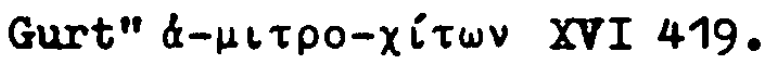

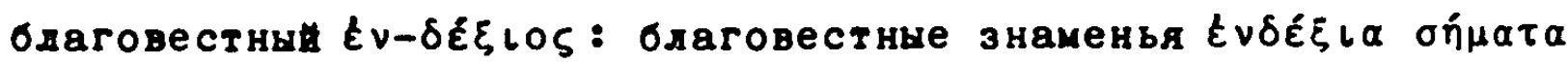

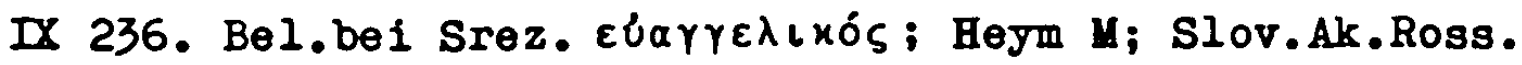
1806.

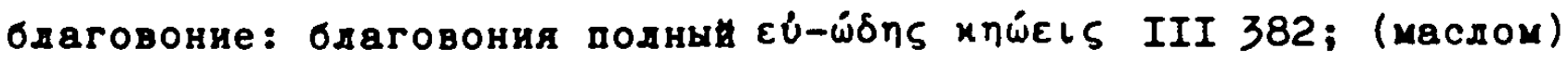

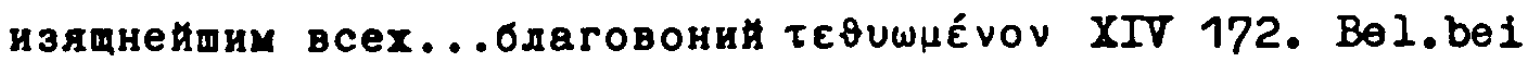

Srez. u. Polik. $\varepsilon b \omega \delta i \alpha$; Heym R,M; Slov.Ak.Ross.1806.

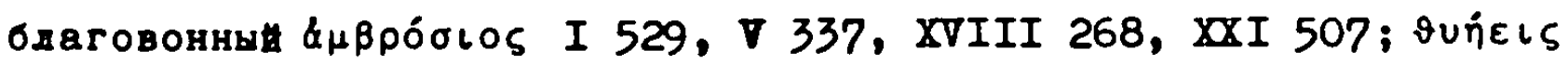

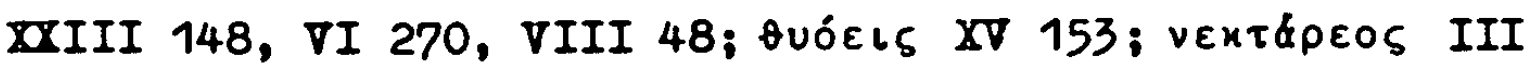

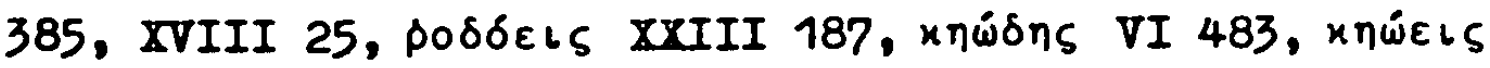
VI 288; благовоннын тук хиі́о I 66; в бдаговонные хертвы sinngemäB eingefügt XXIV 34. Bel.bei Srez. Eúwons; Polik.

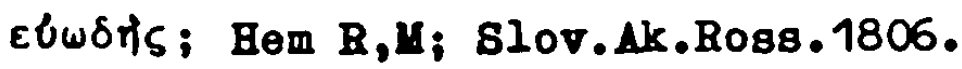

бдагодарность xápls IV 95, D 316, XIV 235, XVII 147; sinngemäB übersetzt VI 527, XIV 267, XXIII 873. Bel.bei WeiBmann; Beym R,M; Slov.Ak.Ross.1806. благодарнын $\pi \rho \delta-\varphi p \omega \nu$ XIII 647. Bel.bei Srez. U.Polik.: $\varepsilon$ bxá- 


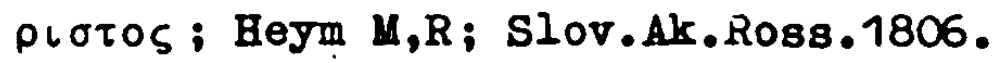

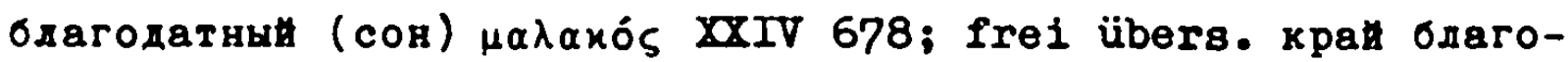

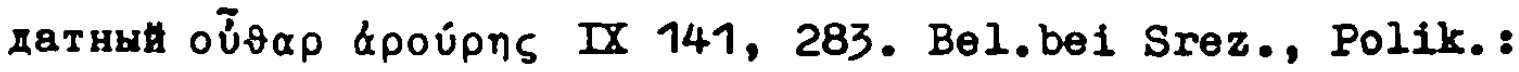
$x \varepsilon \chi \alpha \rho \iota \tau \omega \mu \varepsilon ́ v 05 ;$ Ross.Cell.; Heym M,R.

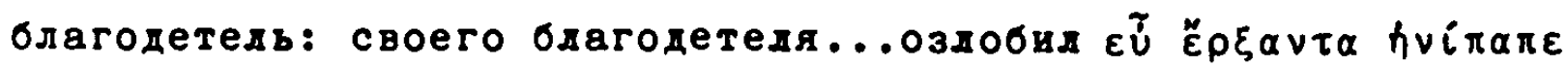

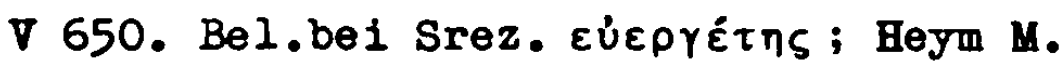

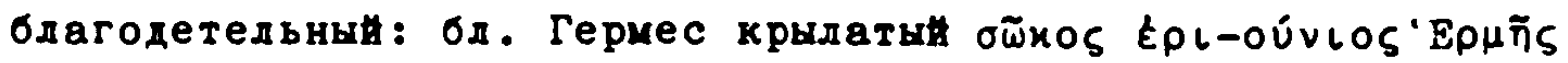

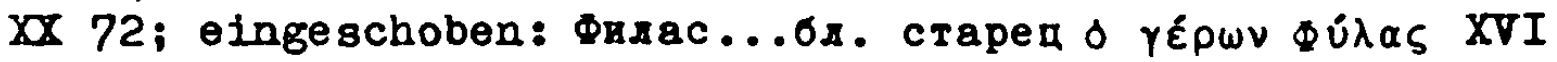

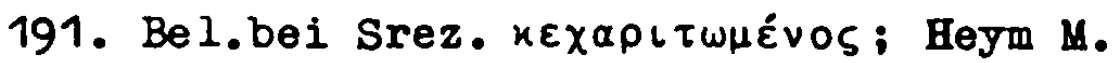
благодемщи: sinngemäв eingef. XVIII 293. Bel. bei Srez. блa-

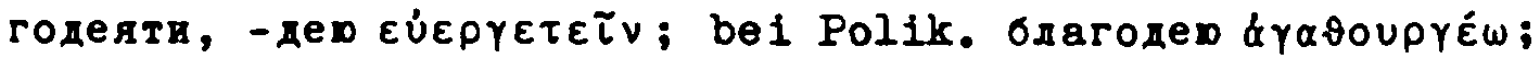
bei Nordstet благодеять, -дер, bei Heym благодев. бдагодумны $\mu \varepsilon \gamma \alpha \dot{a}-\vartheta \cup \mu о 5$ II 53. благодушнын $\mu \varepsilon ү \alpha \dot{\alpha}-\theta$ но XIII 400, 598, XVI 286, XXIII 168;

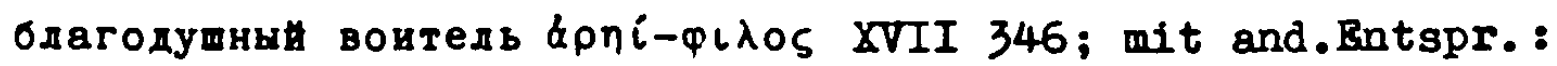

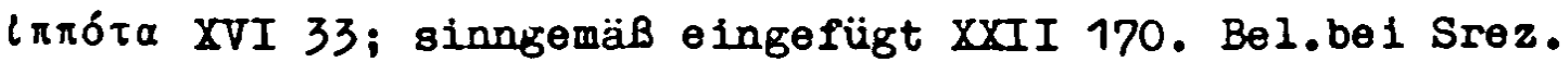

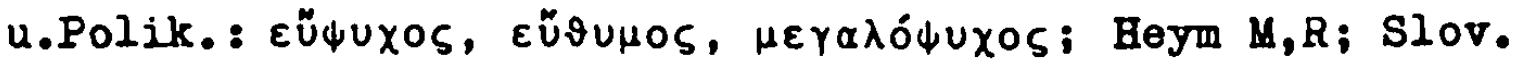
Ak. Ross.1806.

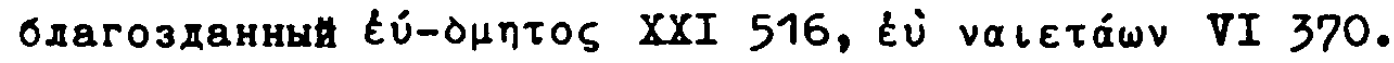

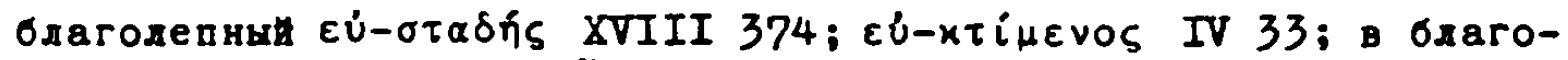

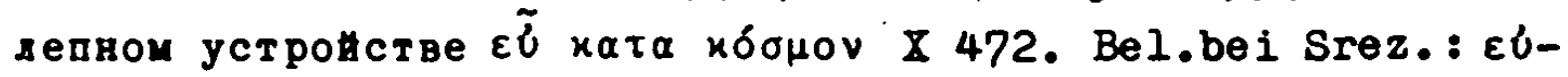

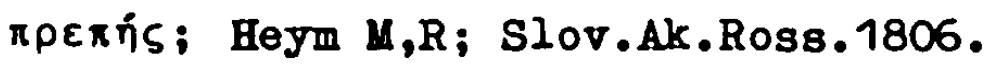

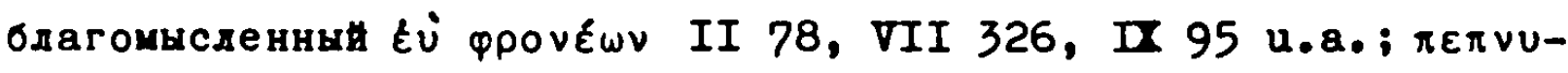

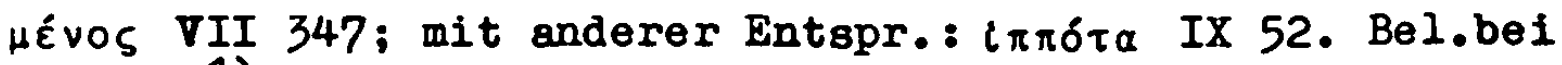
Sokolor ${ }^{1)}$.

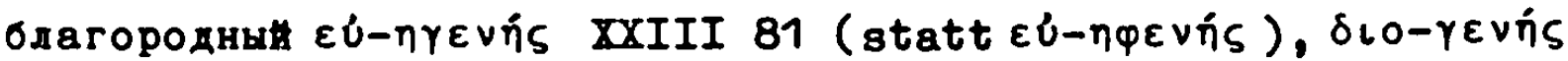

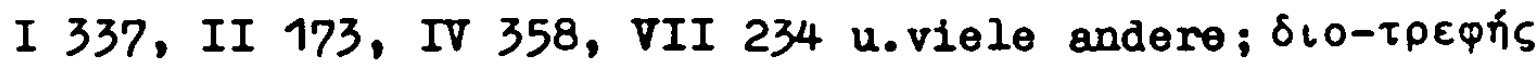

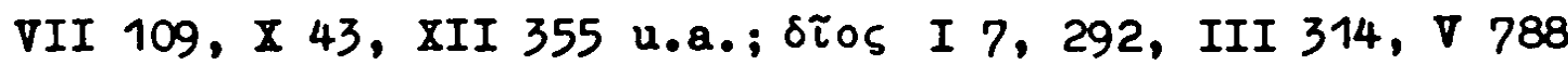

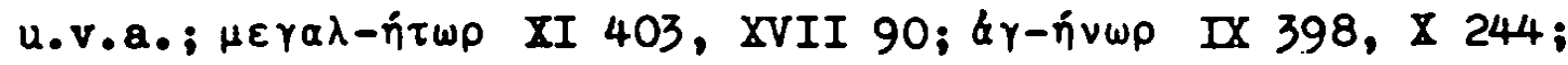

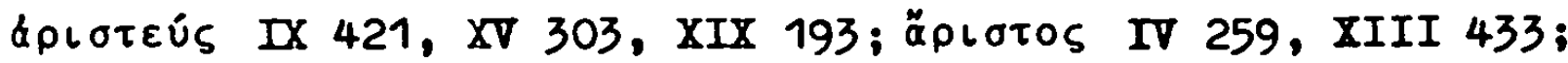
im Griech. verbal: хто на борях бдагороден душон бऽ $\delta \dot{\varepsilon} x^{\prime}$

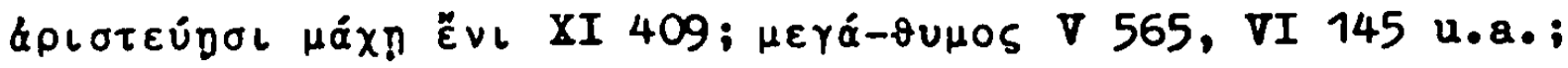

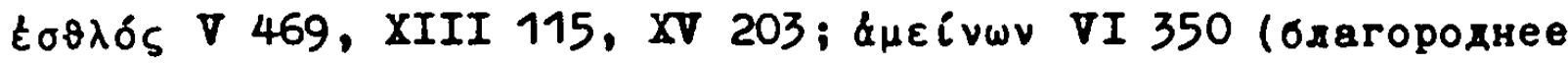

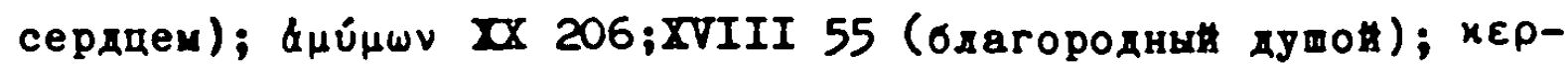

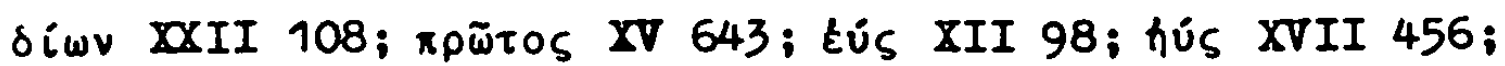

1.Slov.Ak.Ross.1806 u. Heym zitieren бraromыслиe u. osaroмысдящй. 
xUठ์́̉

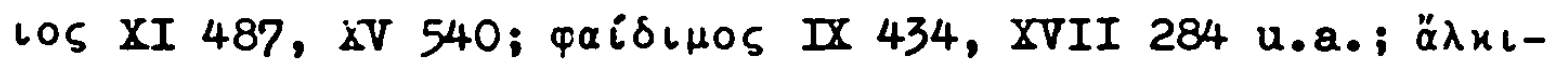

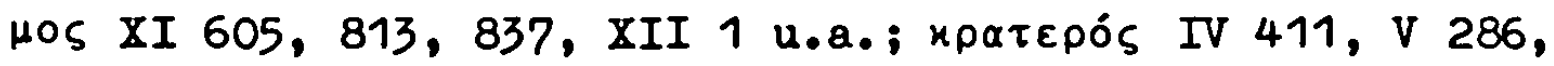

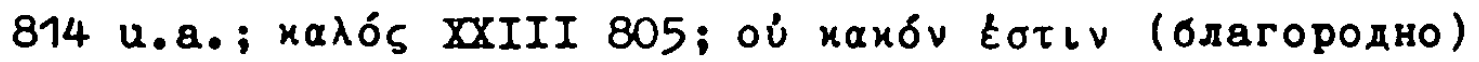
XVIII 128; фi

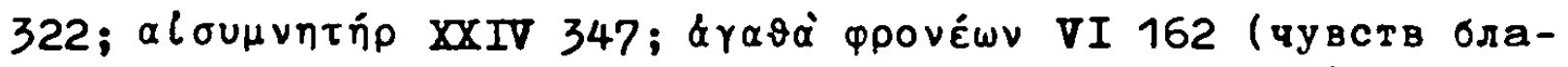
городных исполненнын); красота бл., краса бл. \&үлаї $V$ VI 510,

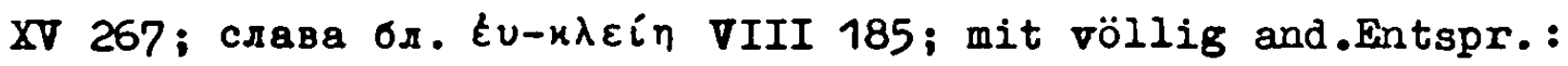

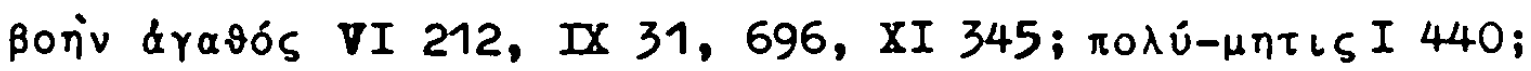

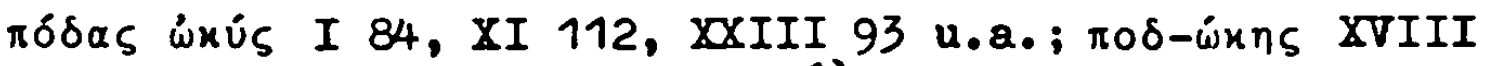

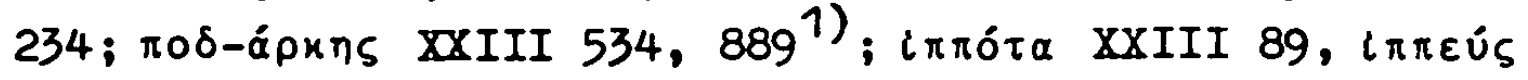

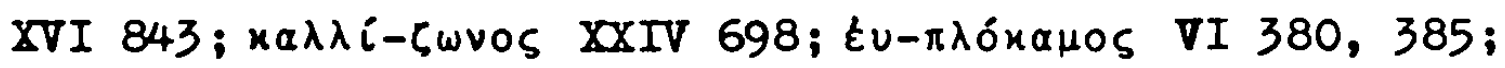
ohne Entspr. sinngemä В eingefügt steht благороднын XXIII 276, III 146, 211, IV 360, 367, V 180, VI 270, 287 u.v.a.

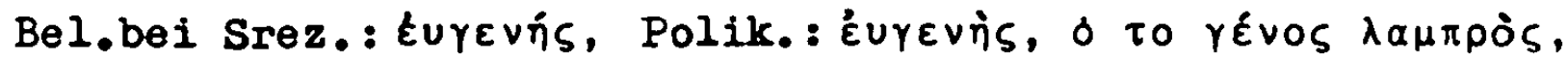

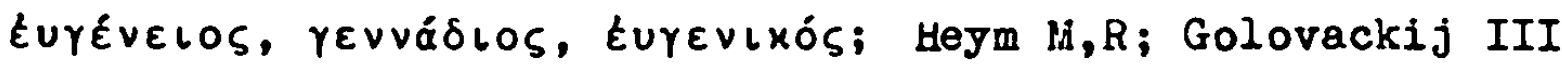
Teil 1, S.259. небдагороднын $\delta \eta \lambda \eta \dot{\mu} \omega \nu$ XXIV 33. Bel.bei WeiBmann.

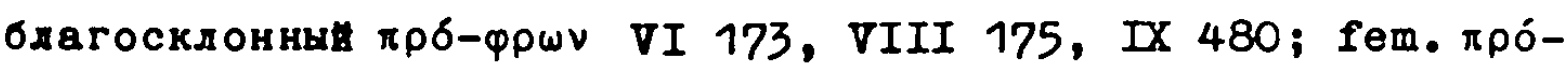

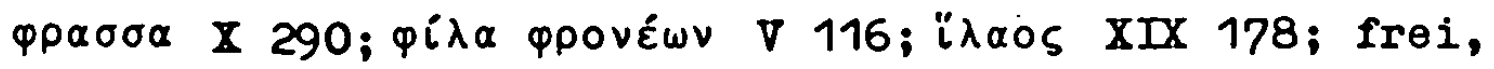
aber sinngemäB übers.z.В. Х 280: благосклоннор будь мне

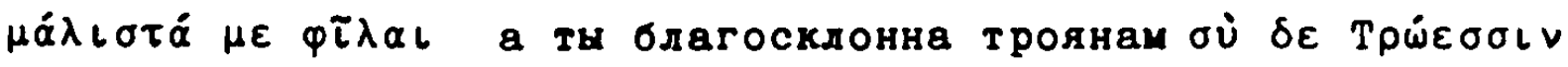
\&prifelS XIV 192. Bel.bei Heym M,R; Slov.Ak.Ross. 1806.

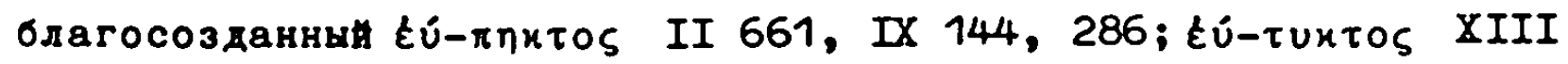
240.

благотворнын (Сон) $\mu \varepsilon \lambda i-\varphi \rho \omega \nu$ II 34; $\mu \alpha \lambda \alpha x \delta \varsigma \varsigma$ X 2. Bel.bei Heym $M, R$; Slov.Ak.Ross.1806.

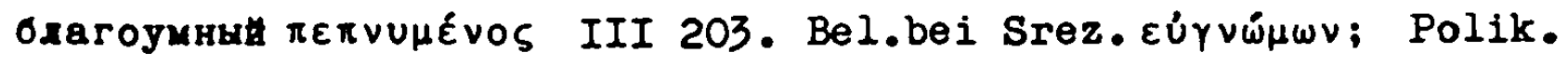

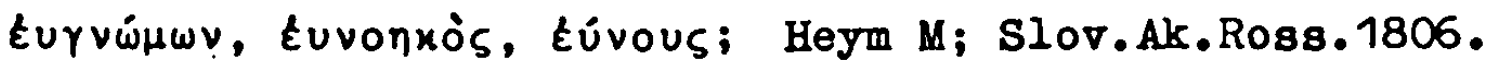
благочестивн: sinngemäв elngefügt: Нестора, благочестивого

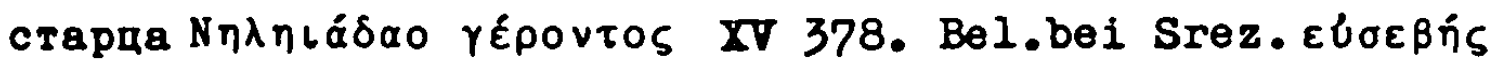

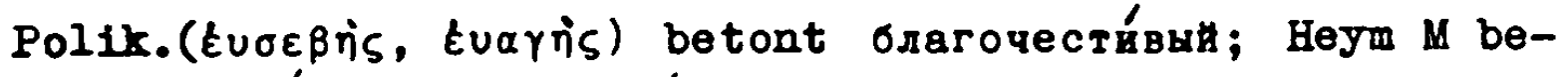
tont-qести́вы, Неут В -че́стивы. Sokolov, Hilferding 844 , 845, 1154, 1243 u. Sobolevgkij I Nr.182, 184 betonen - чести́вы.

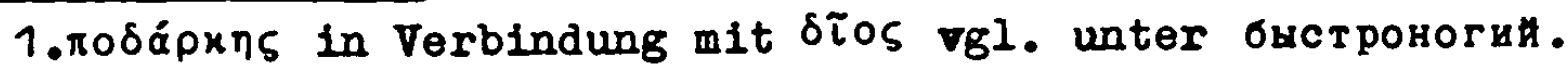


блистательногладки $є \dot{-}-\xi \varepsilon б \tau о \varsigma$ XIII 613.

блистательнооки $\gamma \lambda \alpha \cup x-\tilde{\omega} \pi\llcorner\varsigma$ XXIV 26.

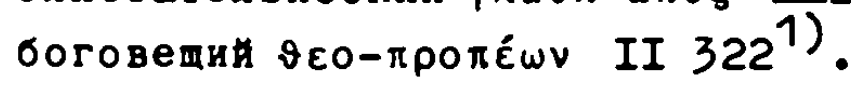

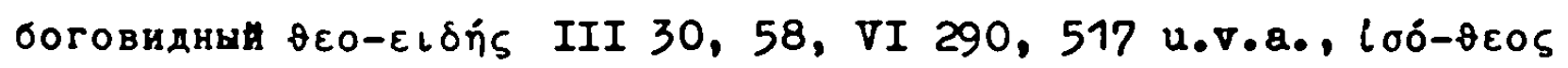

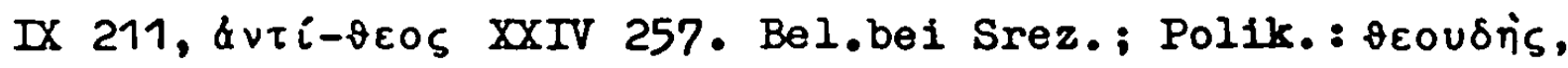

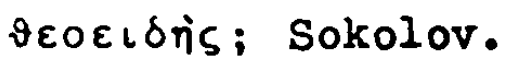

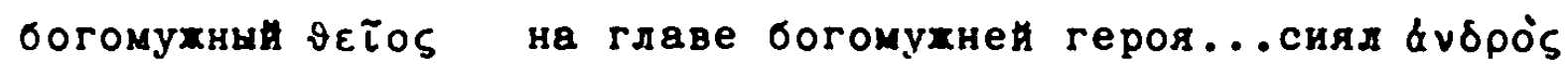

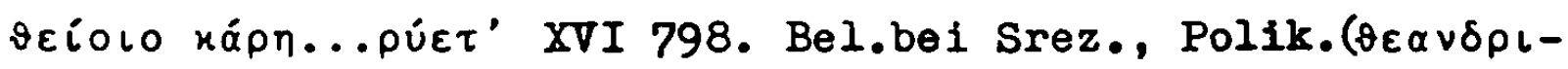

xòs) u. Sokolov, allerdings mit hartem Suffix: богомухны.

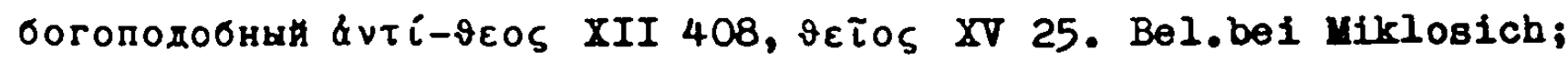

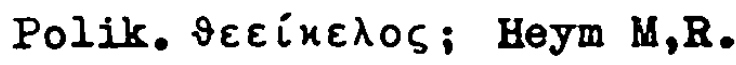

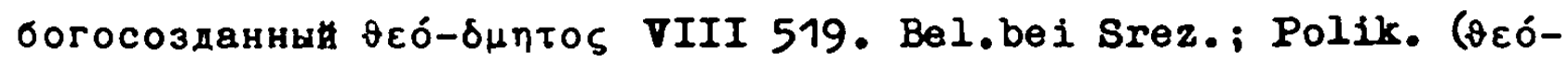

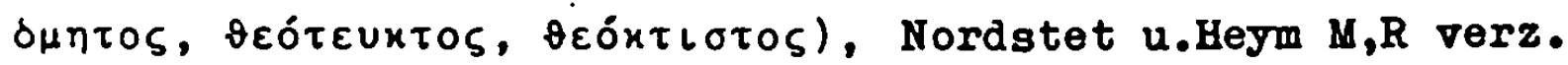

богозданнни.

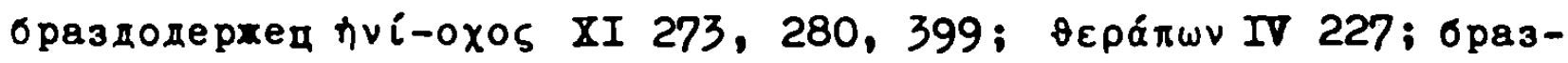

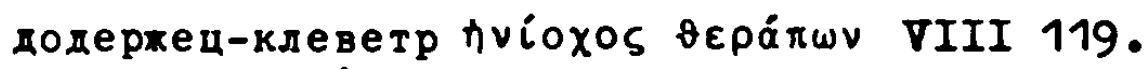

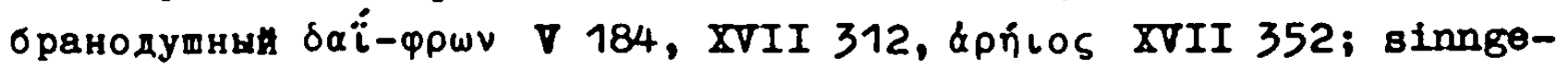

mäß eingefügt II 745 .

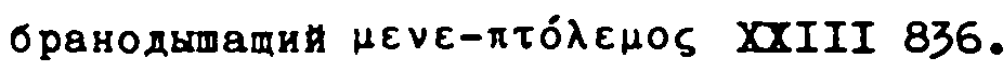

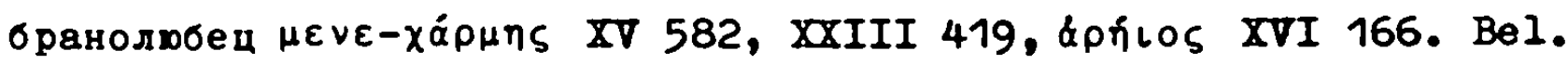

bei Miklosich.

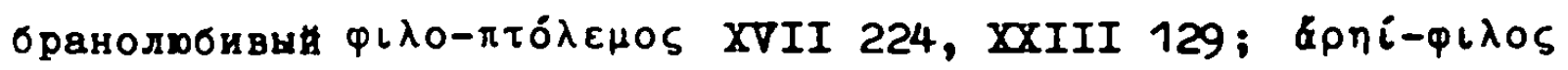

XVII 319. 336, $\mu \varepsilon v \varepsilon-\chi \alpha ́ \rho \mu \eta s$ IX 529. Mit anderer Entspr.:

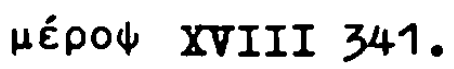

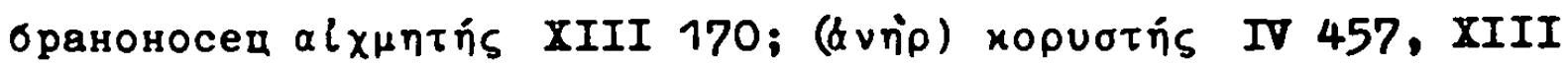

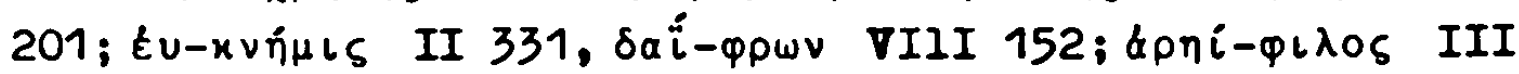
523; mit anderer Entspr.: $\mu \dot{\eta} \sigma \tau \omega \rho$ XVI 759, $\mu \varepsilon \gamma \alpha \lambda-\dot{\eta} \tau \omega \rho$ VIII

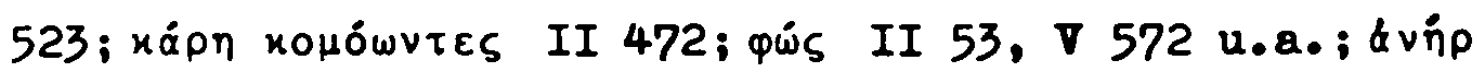
I 260, $\nabla 37$ и.а.; frei übers.: два браноносда стояди $\delta u^{\prime}$

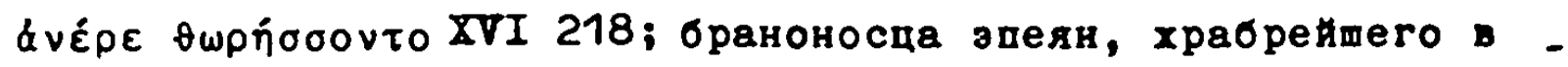

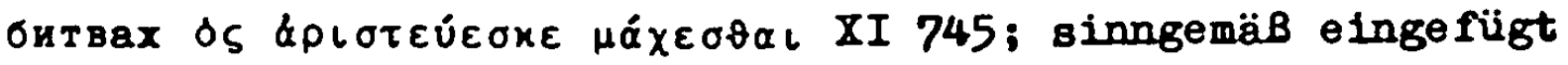
I 196, IV 374 u.a.

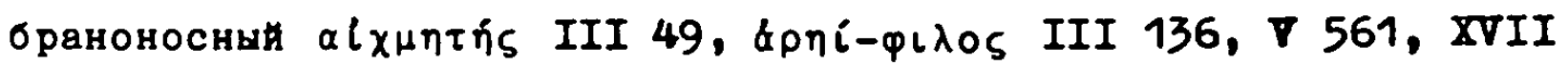

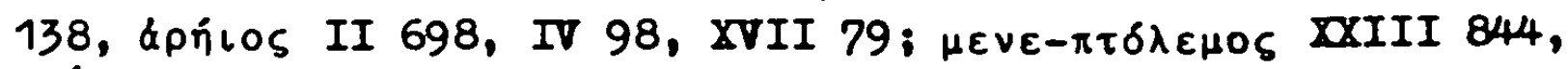

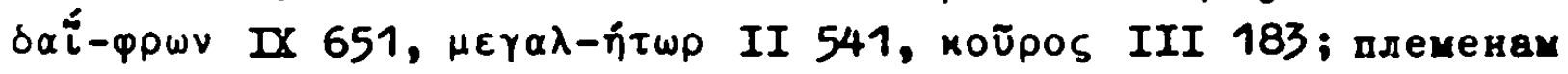

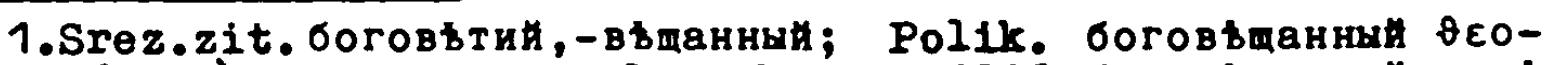

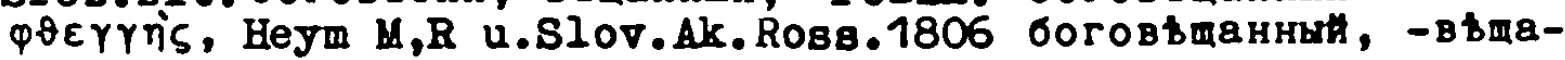
тель. 


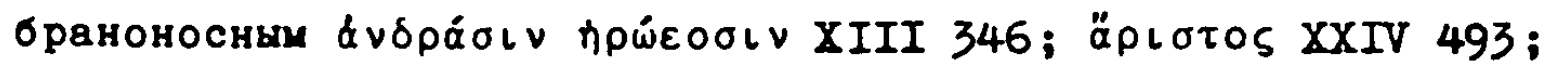
obne genaue Entspr.eingefügt II 572, X 288 u.a. Bel.in Slov. Ak.Ross.1806; Heym S; Sokolov. бронеблещущин фаiбцнољ(immer als Beiwort Hektors) VI 494, XV 65, XVIII 175.

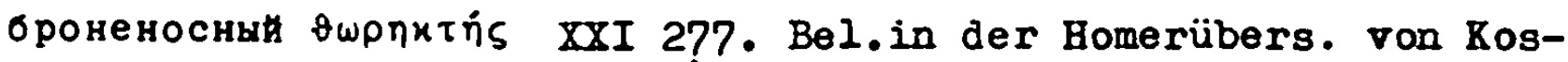
trov, vgl. Jegunor $\mathrm{S.95}{ }^{1)}$.

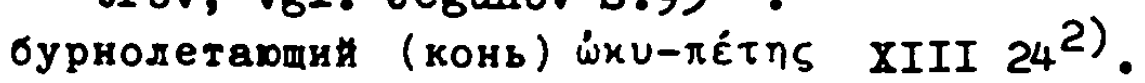

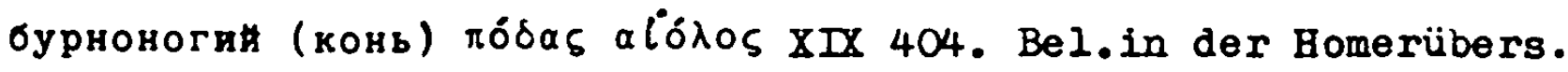

von Jekimov, vgl. Jegunov S.59.

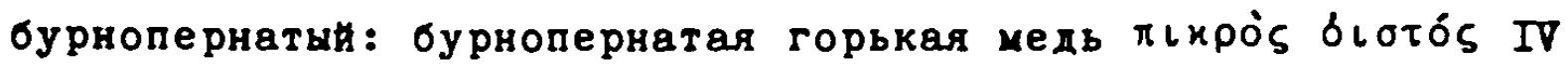
134.

бурнотечны \&ُá-pрооs II 845. быстроборнын тахن́s XIV 442. быстроводнни: поток быстроводнын, глубокопучинны це́үаऽ пота-

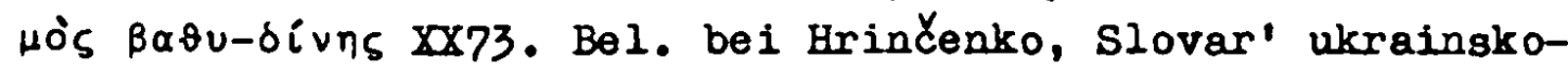
gо jazyka, Kiev 1907-09 alsоистроводнни. быстрокатнн $\ell \dot{U}-\tau$ тохо丂 XXIV 190;бнстрокатные воды роаi $\nabla 774$.

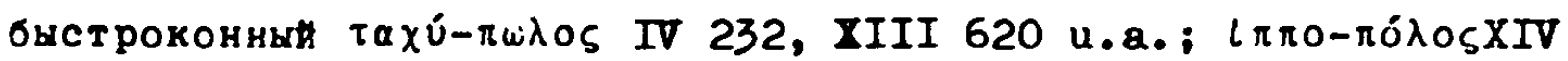

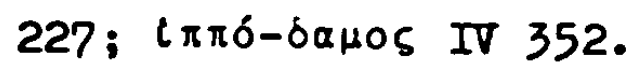

быстрокрылын: ястреб, ловед быстрокрылы ірп६

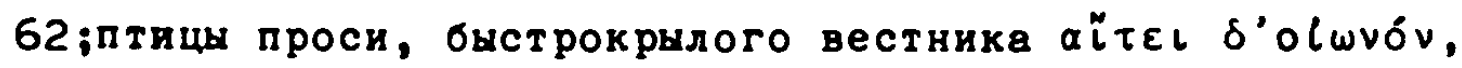

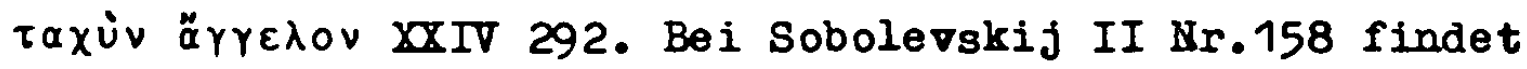
sich бшстрокрыленькин.

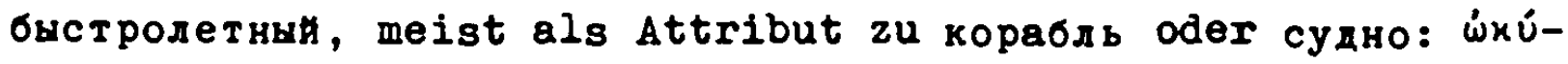

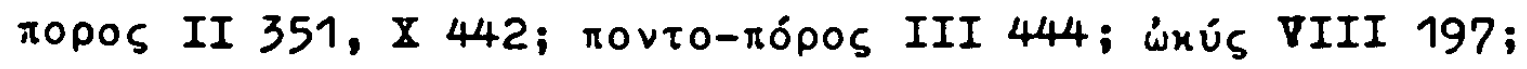
Өoós I 12, X 306 u.a.; Eión I 306; mit anderer Entspr.:

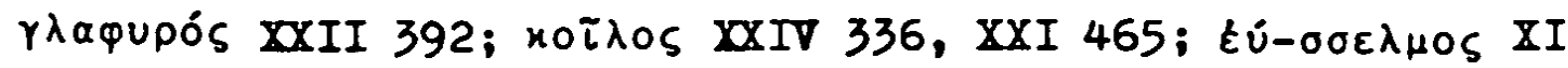

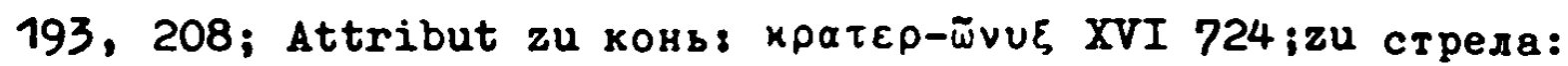
$\lambda \alpha \iota \downarrow \varepsilon \rho \delta \varsigma$ XXI 278; sinngemäB eingefügt VIII 392. Bel.in Trediakovskijs Tilemachida ${ }^{3)}$ und im russ.Närchen ${ }^{4)}$.

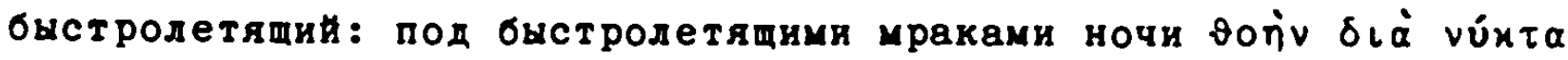

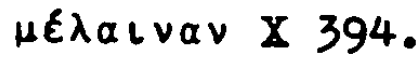

1.Beym $S$ verz. броненосед in der Bed."Gürteltier".

2. Im gleichen Zusammenhang ist VIII 42 бурно летахин getrennt geschrieben.

3.Vgl. Tschi2ewskij, 2fsLPb Bd.XVII S.114ff.

4.VGl.Afanas'ex, Narodnjja russkija skazki, Moskau 1914, zit.von Dickenmann S, 194 . 


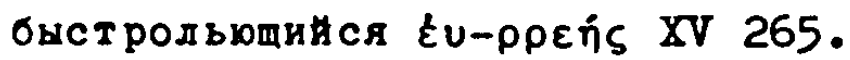

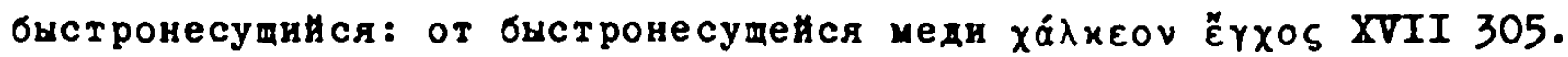
быстроногин: auf Tiere bezogen $\mu \tilde{\omega} \nu \cup \xi$ VIII 139, 432, IX 127

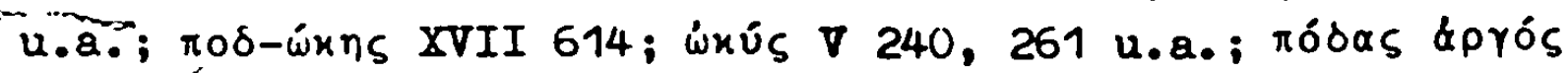
XVIII 578, taxús XI 113, XVIII 584; auf Personen bezogen,

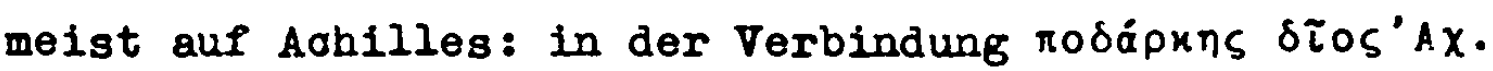
I 121, II 688, XI 599 u.v.a.; verstärkt durch pncтareds I

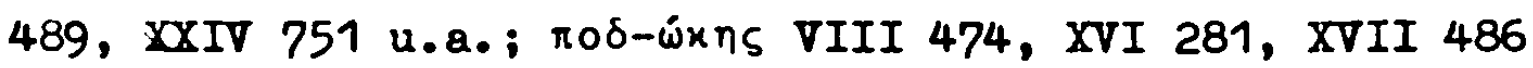

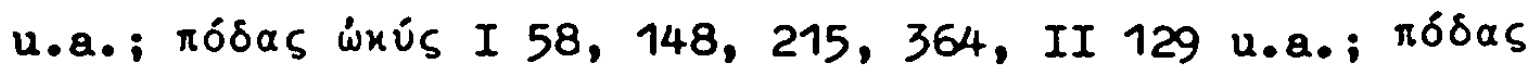

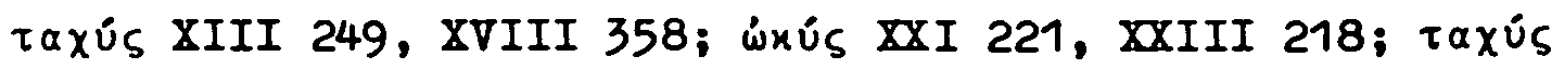
II 527, XIII 66 u.a.; $\delta$ Ios VI 414, XVIII 228, 305 u.a.;

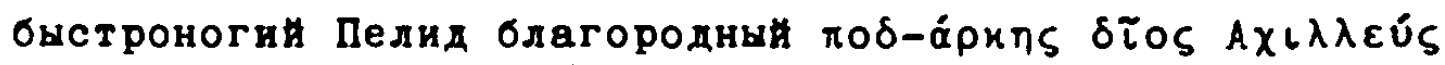
XXIV 668; frei, aber sinngemäв übers.:избегал быстроногия,

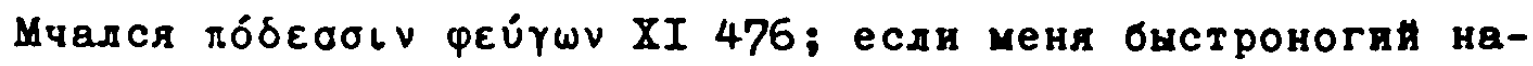

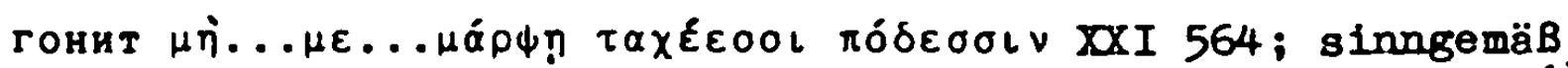
eingefügt I 223, VII 113, XIV 50 u.a. Bel.im russ.Märchen ${ }^{1}$ ? bei Deržavin, Осень во время освды Очакова und in Дарьдевица.

бьстрооки $\varepsilon \lambda i x-\omega \psi$ I 389, III 190, 234 u.a.

быстропврнын: sinngemäв eingefügt:как оред быстропарнны ш̆ك $\tau$ ' aletós XVII 674. Bel.in derpuторикa des Bosma Grek ${ }^{2)}$; bei Deržavin, Лeтo.

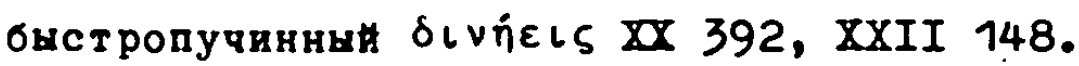

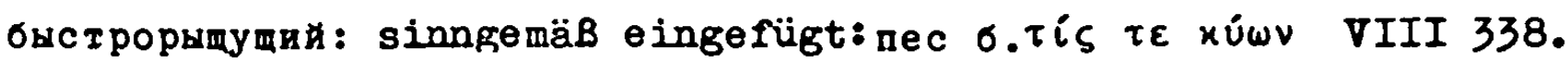

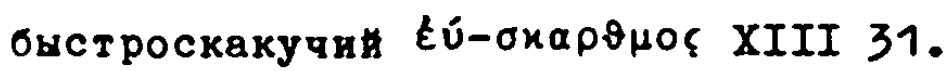

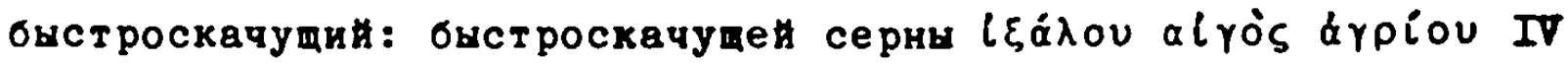

105; sinngemäB eingefügt XII 120.

быстротечнн бᄂ

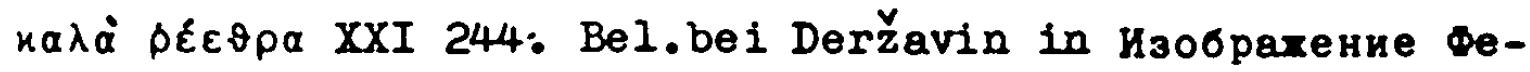
лиды und in Памятник; in Slov.Ak.Ross.1806; in der Homerübers.von Kostrov, vgl.Jegunov S.95.

вездесущин: ohne genaue Entspr.: Вы...бохества, вездесуди

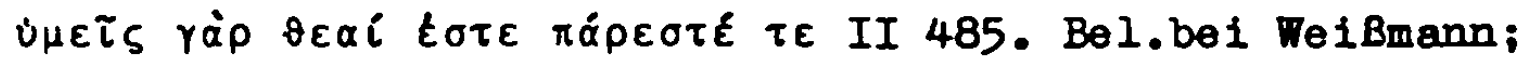
Slov.Ak.Ross.1806; Heym S.

1.Vgl.Afanas'ev, Narodnyja russkija skazki, Moskau 1914, zit.von Dickenmann S, 194 .

2.Vgl.Hüttl-Horth S.17. 


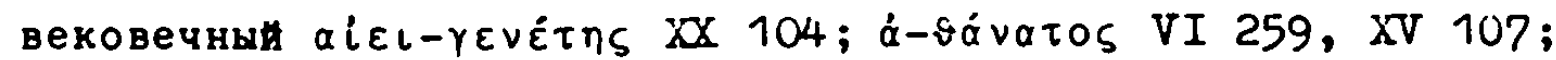

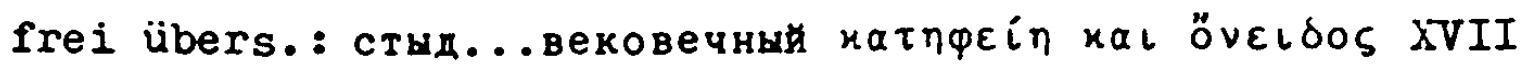
556. Bel.bei Srez.; Slov.Ak.ross.1806; in der Volksdichtung: K.Danilov S.420, Hilferding S.837, 916, Sobolevskij I Nr.499, IV iir.267 u.a.

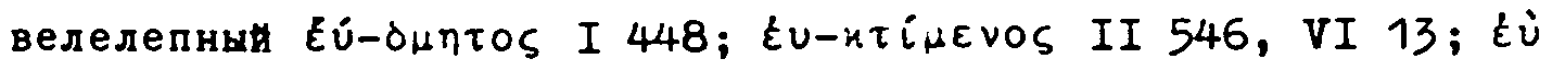

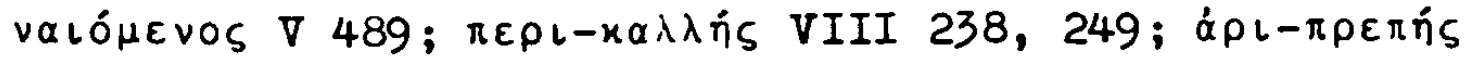
XV 308; всего покрывающй, бурный свон щит велелепнын, весь

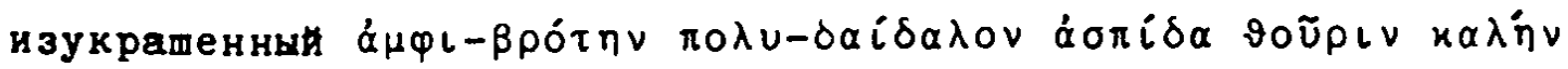

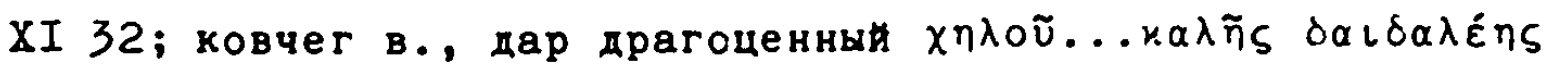

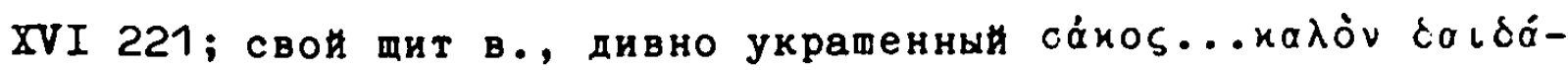

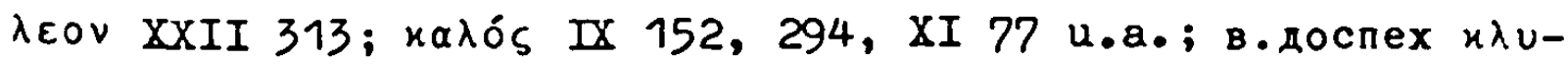
$\tau \dot{\alpha} \tau \varepsilon \dot{u} x \varepsilon \alpha$ XVII 70, XIX 11. Bel.bei Srez, und Polik. $\mu \varepsilon \gamma \alpha \lambda o ́-$ $\pi \rho \varepsilon \pi \dot{s}$; heym M,R; Slov.Ak.Ross.1806.

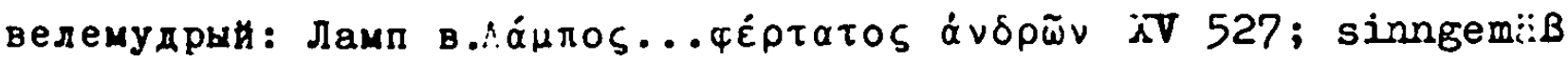

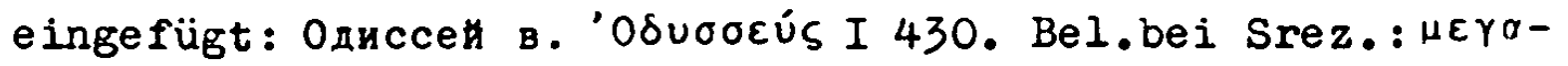
$\lambda \delta$ ¿owv; Heym li,s; Slov.Ak.ross.1806.

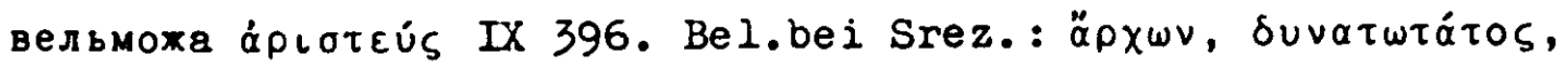

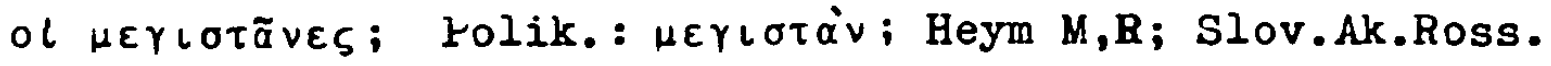
1806.

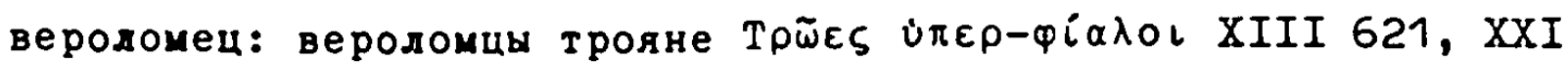
459; auf Ares bezogen $\alpha \lambda \lambda \lambda \sigma-\pi \circ o ́ s-\alpha \lambda \lambda \circ \varsigma \mathrm{V}$ 831. Bel.bei Nordstet; Heym M,R; Slov.Ak.Ross.1806.

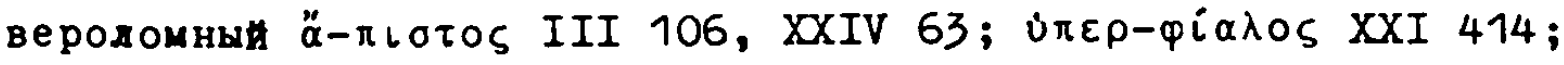
веролокно илєр ӧрица IV 271; нарушив клятвы святье мы веро-

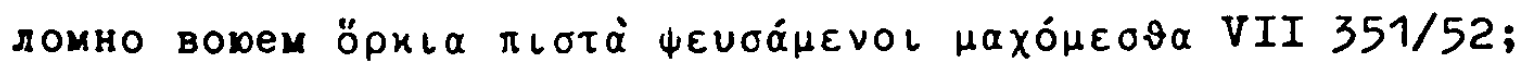
frei übers. XIX 265; XXI 457; sinngemäß eingefügt III 301 , $\nabla$ 834, XI 279. Bel.bei Nordstet; Ross.Cell.; Heym M,R; Slov.Ak.Ross.1806; Sobolevskij VI Nr.267.

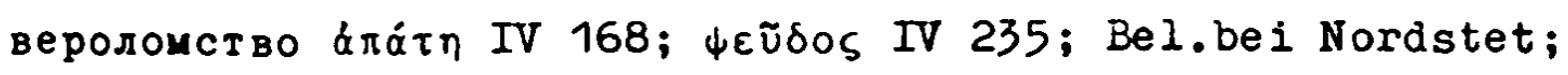

Ross.Cell.; Heym M,R; Slov.A.k.Ross.1806.

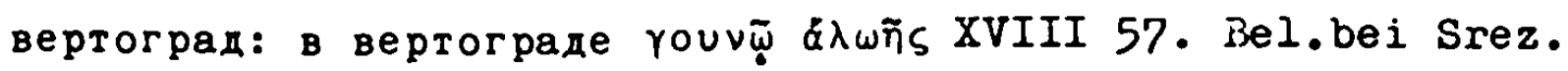
ип̃ ветроногин: immer in der Verbindung ветроногая вестница Зевса

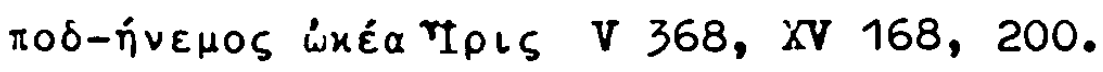

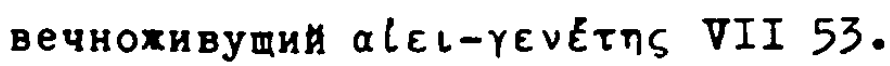

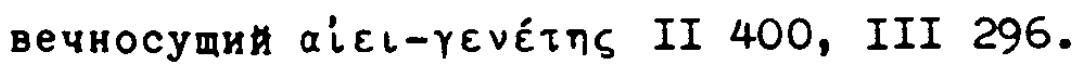




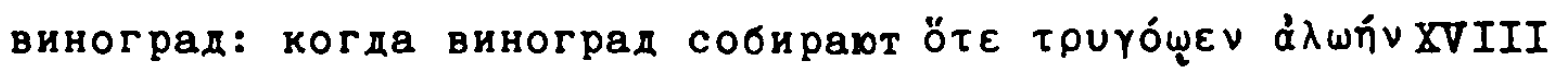

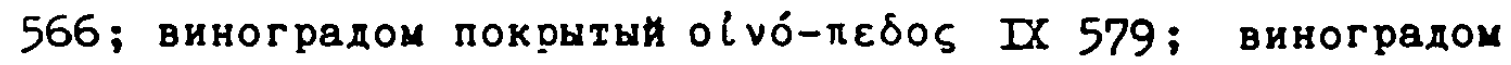

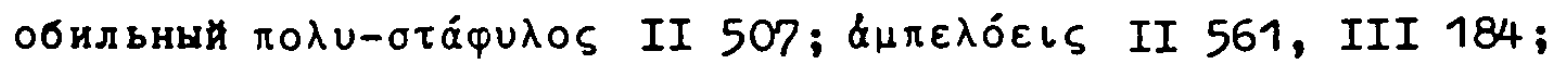
лучшей землей, виноград и пшеницу обильно плодящей $\varepsilon \dot{\mu \varepsilon \vee о ऽ ~}$

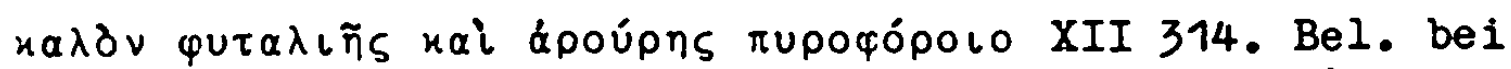

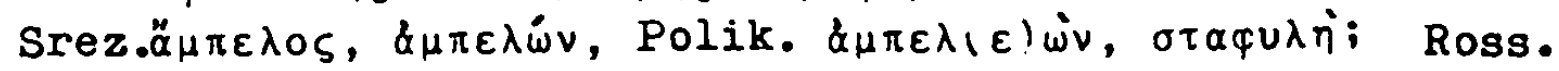
Cell.usiv.

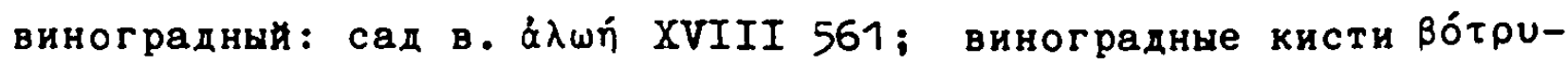
ES XVIII 562.

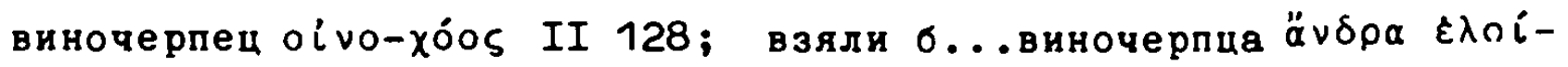

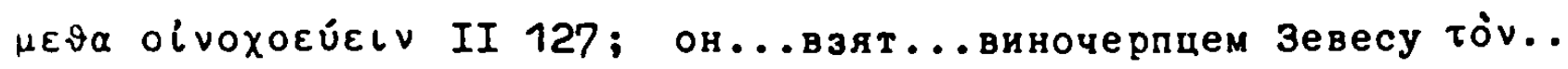

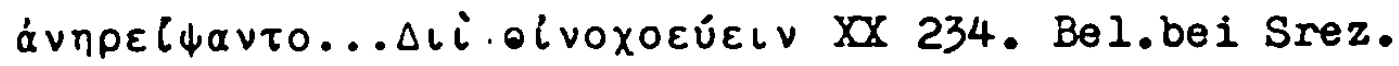
olvoxóos. Slov.Ak.Ross.1806 = чашник. Dagegen führt Heym M,S виночерпеи in der Bed."Weinglas,-becher" auf, wäbrend bei ihm für "Mundschenk" виночерпчии steht. Bei Polik.entspricht olvoхо́о丂виночерпатель.

водовод "Wasserleiter", "Mann, der Wassergräben zieht" \& vìр

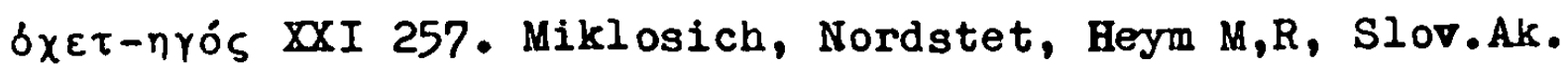
Ross.1806 geben die Bed. "Wasserleitung,-röhre, Kanal". водоем $\pi \lambda$ uvós XXII 153. Bel.bei Nordstet; Heym M,R; Slov.Ak.

Ross. 1806.

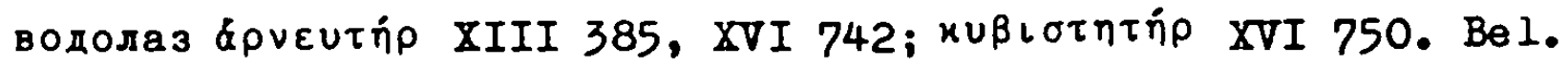
bei Ross.Cell.; Heym M,R; Slov.Ak.Ross.1806.

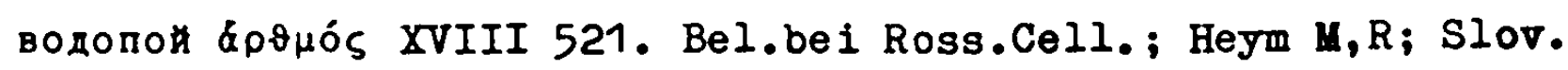
Ak.Ross. 1806.

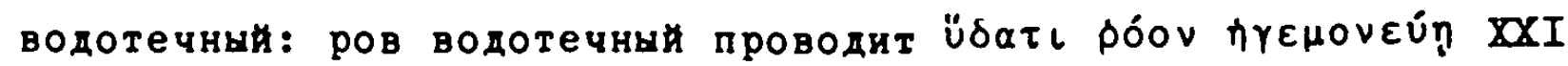
258. Bel.bei Heym M,S; Slov.Ak.Ross.1806.

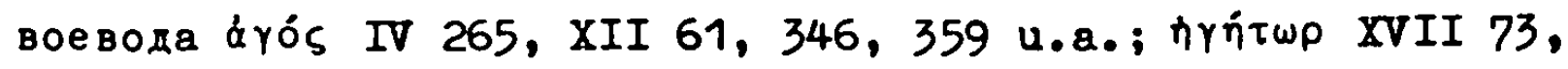

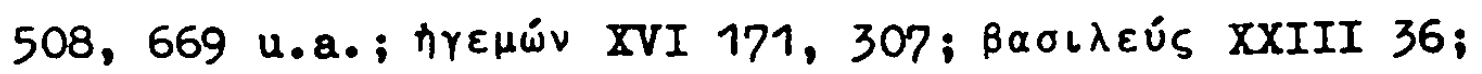

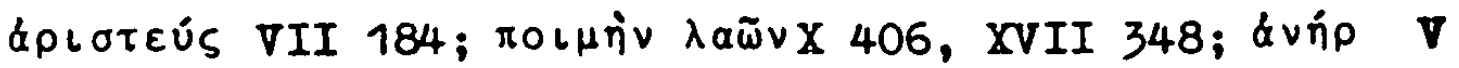

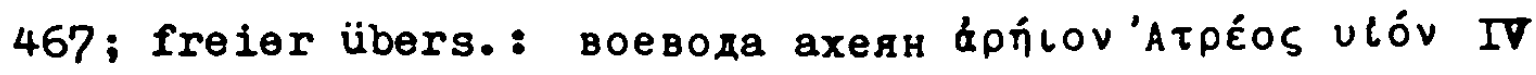

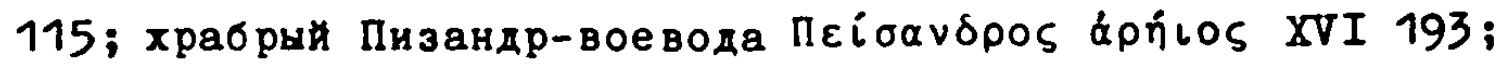

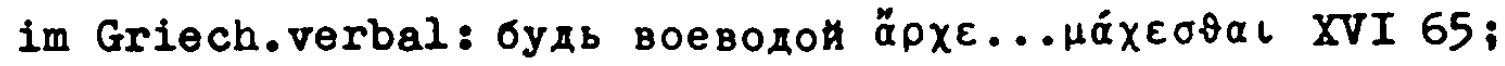

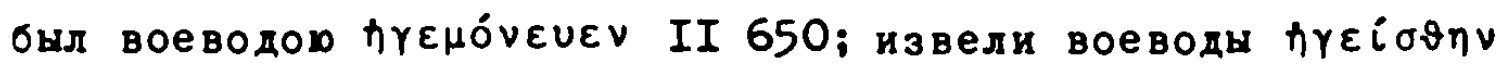
II 731; eingeschoben I 304, V 84, VI 77 u.v.a. Bel.bei

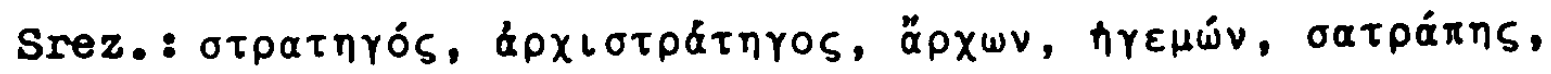

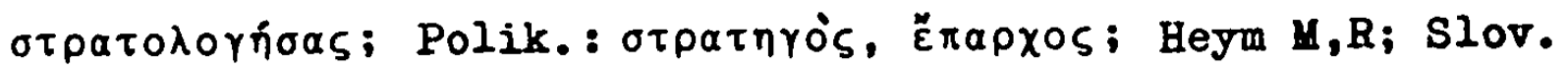
Ak.Ross.1806; in der Volksdichtung: Danilov S.276, Sobolev- 
skij V Nr.605, Hilferding S.241, 299 u.a.

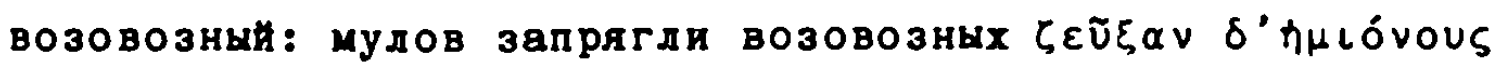

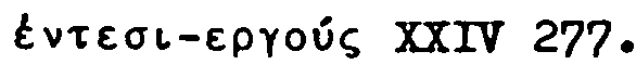

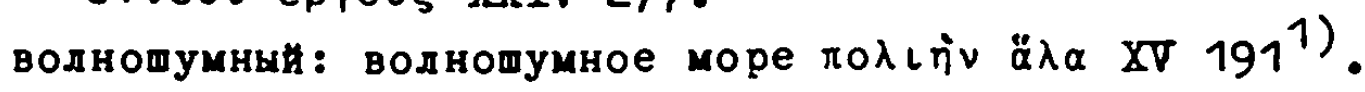

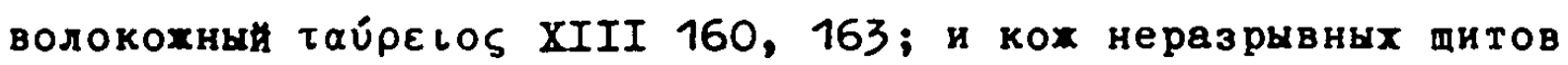
волокохных

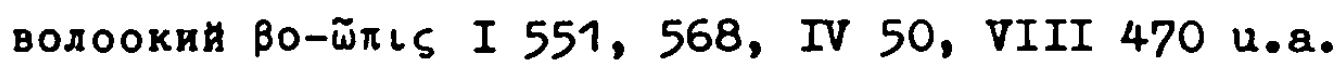

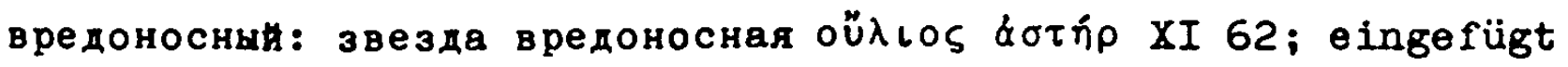

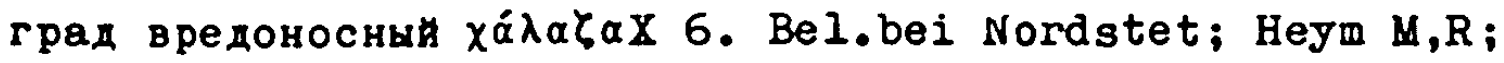
Slov.Ak.Ross. 1806.

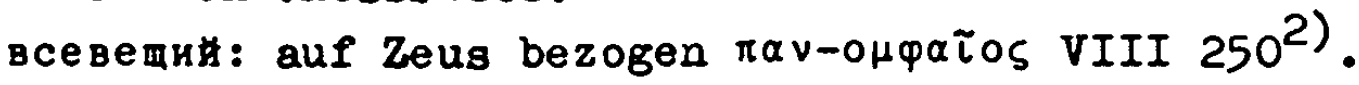

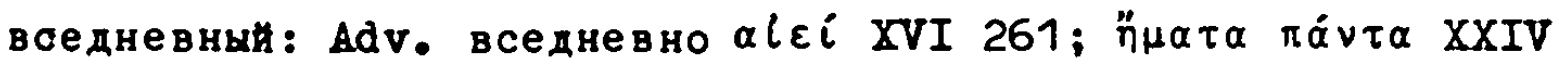
491; вседневная пища йıа XIII 104. Bel.bei Srez.; Poilk.:

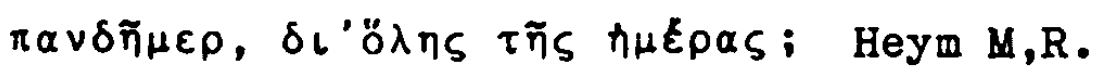

вседушнын: вседушно любила $\mu \alpha \dot{\lambda}\llcorner\sigma \tau \alpha \ldots \varphi \iota \lambda \varepsilon \varepsilon с к \varepsilon \nu$ III 388 . Bel.

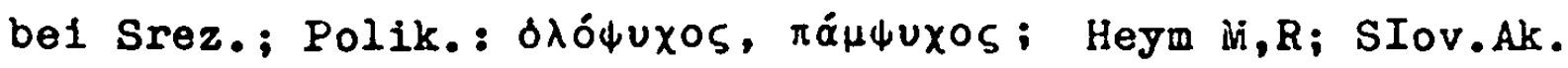
Ross.1806. всемогущи

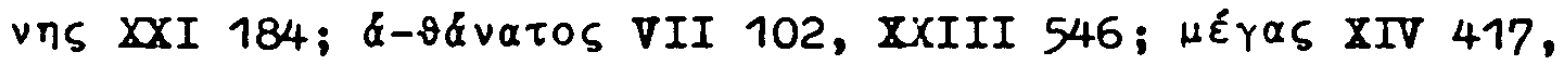

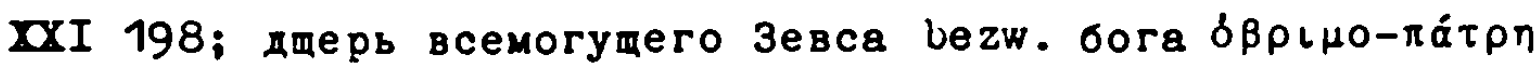
$\nabla$ 747, VIII 391; sinngemäB einge fügt nach бor oder Зевс I 394, IV 84, IX 445, 703 u.v.a. Bel.in Ross.Cell., Heym M,R, Slov.Ak.Ross.1806; i.d.Volksdichtung,Golovackij I 352. всемощнын

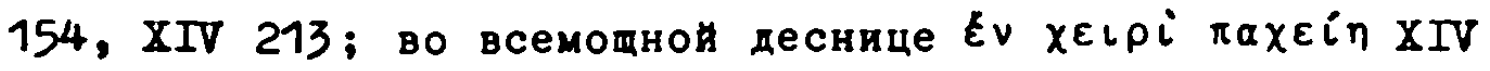
385; sinngemäB eingefügt: XIII 524, 793. Bel.bei Srez.; Polik.: $\pi \alpha v \sigma \vartheta \varepsilon v \dot{\eta} s, \pi \alpha v \alpha \lambda k \dot{r} s, \pi \alpha v \tau o \delta u ́ v \alpha \mu o s ;$ Slov.Ak.Ross. 1806; Heym S; Sokolov. всенароднын: ohne genaue Entspr.XXIII 408, XXIV 462. Bel.bei

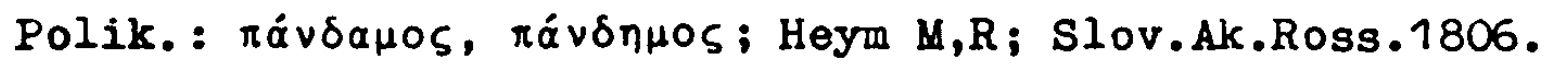

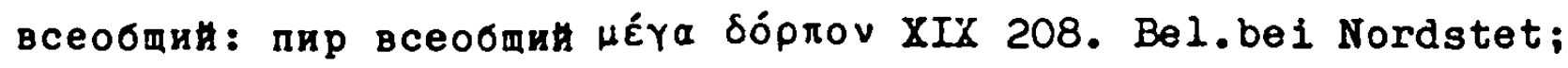

Heym $M, R$; Slov.Ak.Ross.1806.

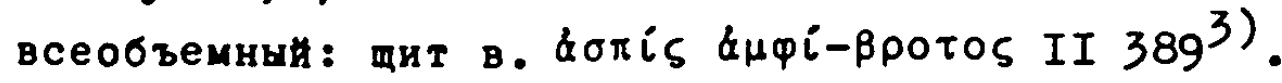

1.Jekinov prägt in seiner Homerübers. волнотумящее море, vgl. Jegunov S.59.

2.Srez.gibt всеведын, Weißmann всеведый u. -ведущий, Nordstet-ведущи, неуm $M, R$-ведец, Неуm $S$-ведущин.

3. Bei Karamzin ist belegt всеобъемлющй, vgl.Hüttl-Wortb. S.91. 
всеорухие: блестящая медь всеорухий ха́лиољ XXI 254. Bel.bei

Srez. U. Polik.: $\pi \alpha v o \pi \lambda i \alpha$; Heym M,R; Slov.Ak.Ross.1806.

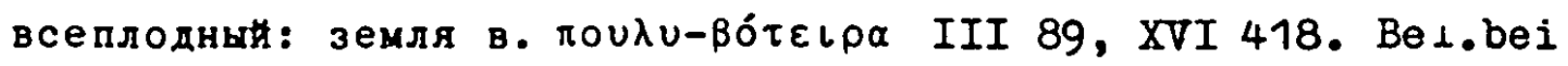

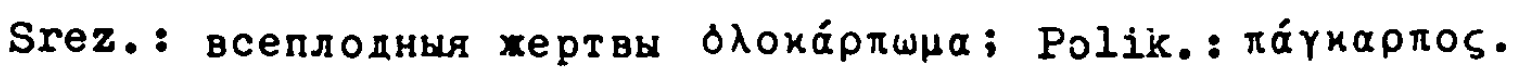

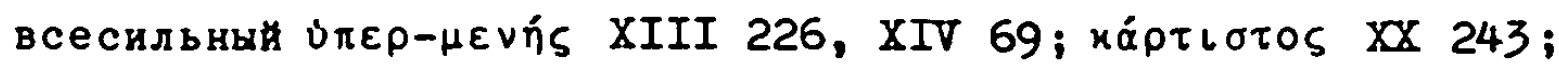

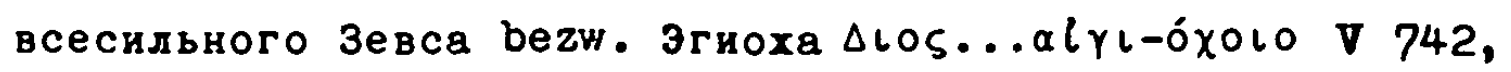

XIV 252; eingefügt XIII 243, XXIV 525. Bel.bei Srez.; Po-

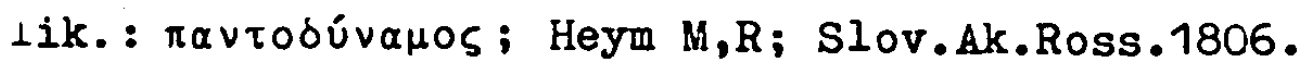
всеувлекающй (сеть) па́v-аүрољ V 487. всечасныи: всечасно $\alpha i \varepsilon i$ II 88, XVI 105. Bel.bei Polik.: к $\alpha \vartheta^{\prime}$

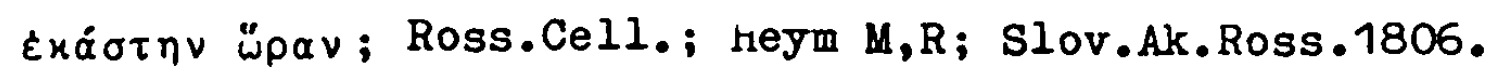

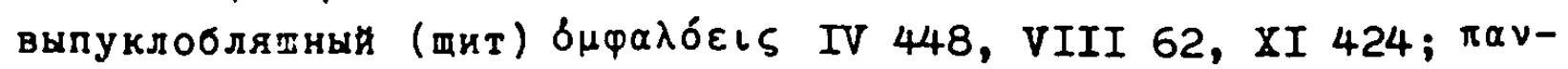

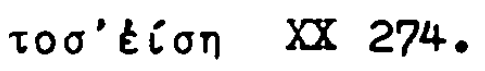

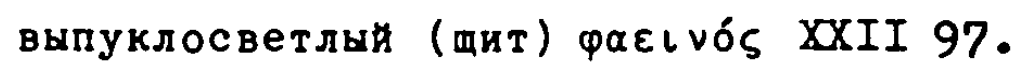

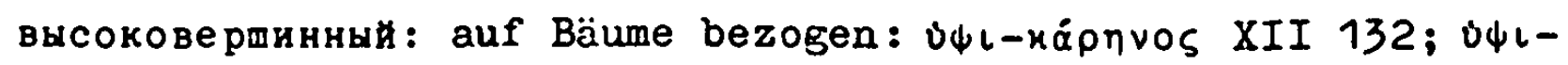

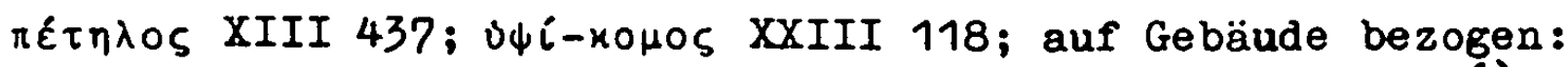

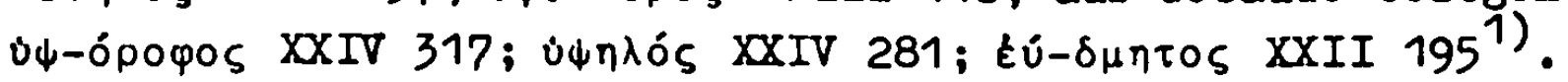
высоковздымавшйся высоковолосы (дуб) ט४i-ионо丂 XIV 398.

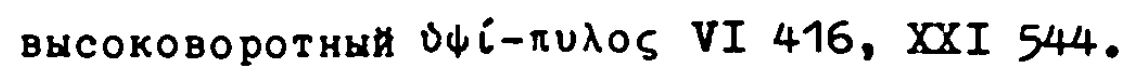

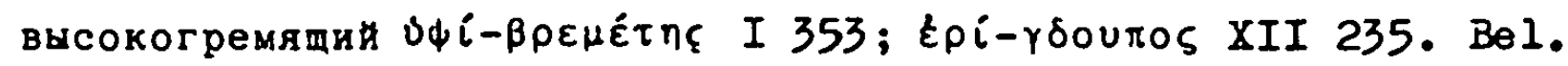

in der Homerübers.von Kondratovič, vgl.Jegunov 5.47 .

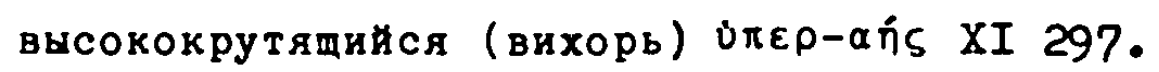

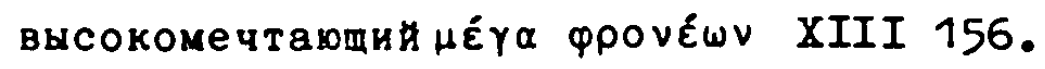

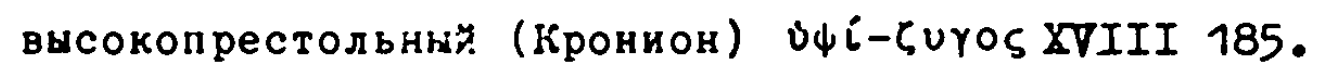

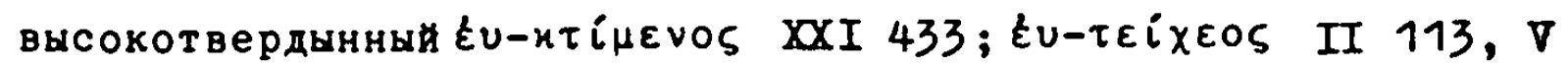

716 u.a.

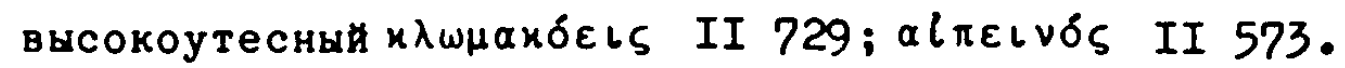

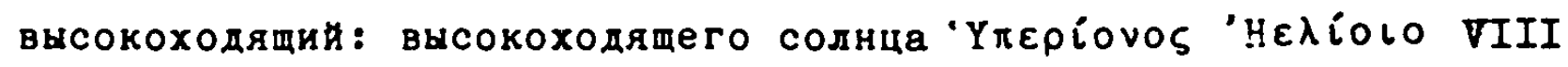
480.

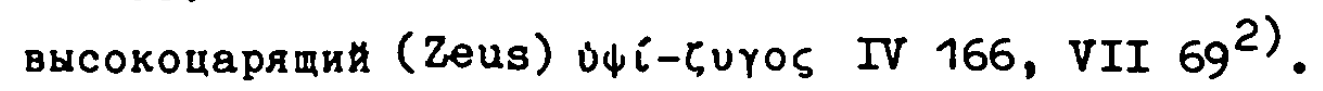
высокочубастый \&хро́-хоноS IV 533.

глубобраздный $\beta \alpha \vartheta \cup ́ s$ XVIII 547.

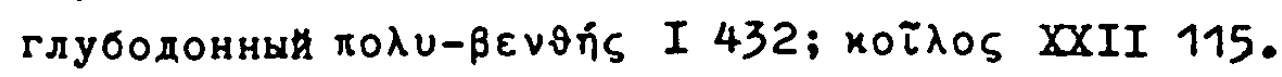

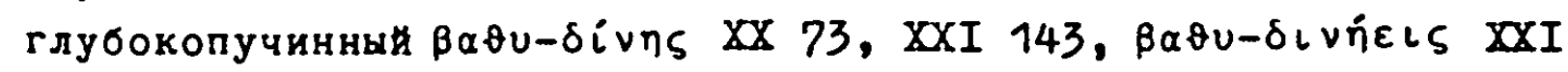

1.Srez., Miklosich und Hеуm M,R verz. високоверхин.

2.Heym $M, R, S$ und Sokolor verz. высокоцарству10 bezw.-царствовать. 


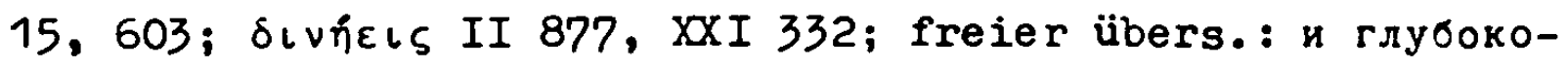

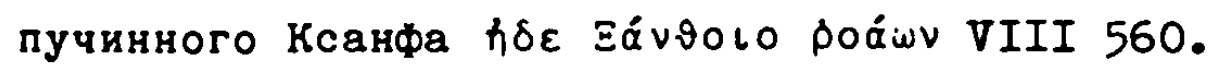
глубокотекущин $\beta \alpha \vartheta \dot{-} \rho \rho о \circ$ XXI 8.

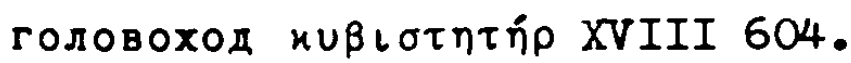

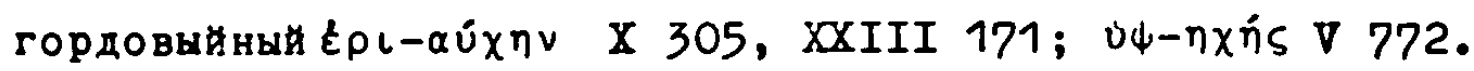

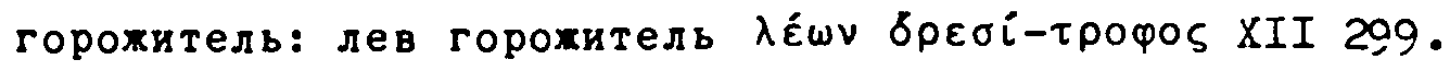

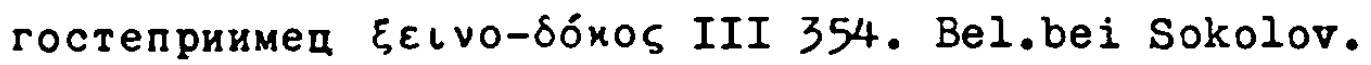

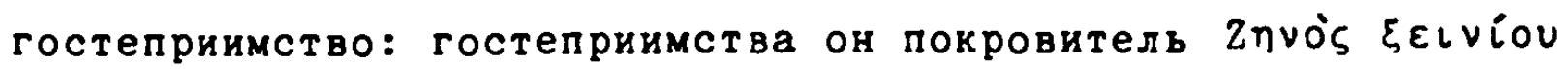
XIII 624/25. Bel.bei Nordstet; Heym M,R; Slov.Ak.Ross. 1806; Sokolov. градоборец ттолі-лорэо丂 II 278, 728, VIII 372 и.а.; Ахиллес

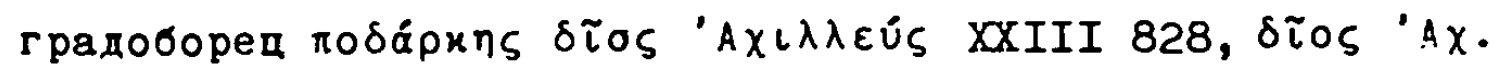
XXII 172, '่xús 'A. XIX 295, Пелид градоборец, сильнын Пе-

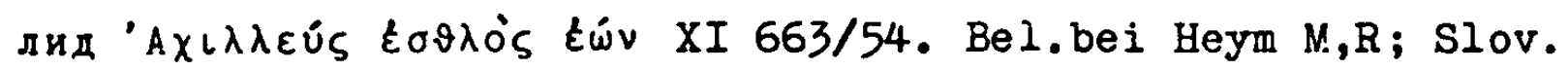
Ak. Ross.1806.

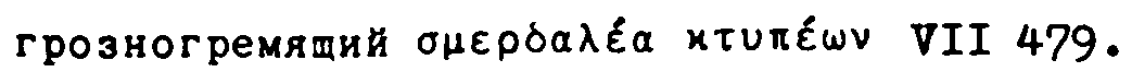

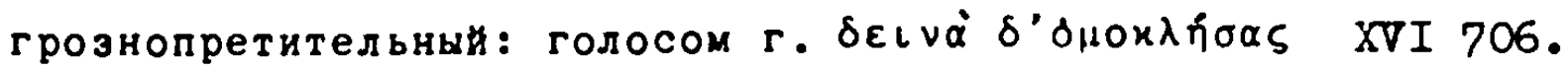
грозноутеснын $\pi \alpha \iota \pi \alpha \lambda \delta \varepsilon \iota \varsigma$ XXIV 78.

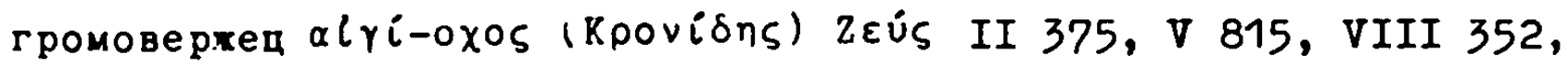

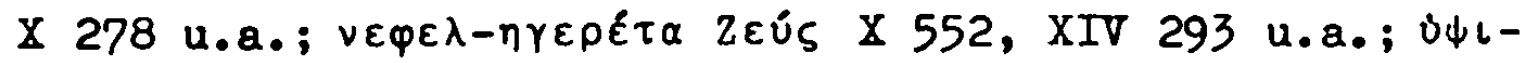

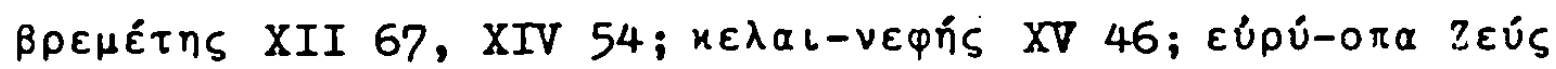
bezw. Kpovions XIV 265, XV 724, XXIV 98, 296; $\varepsilon \rho i-\gamma \delta o u \pi \circ s$

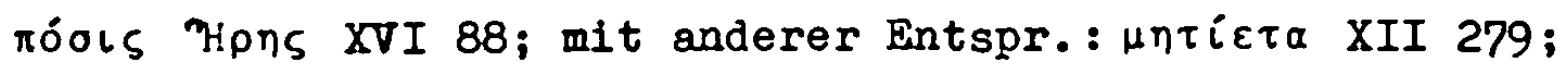

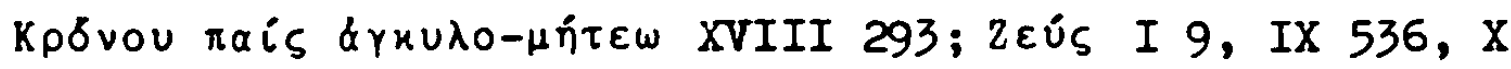

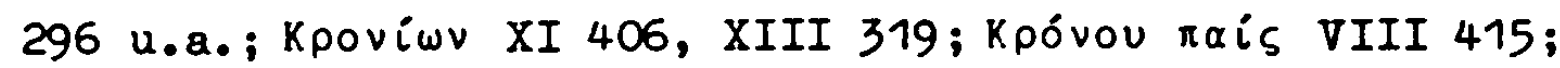

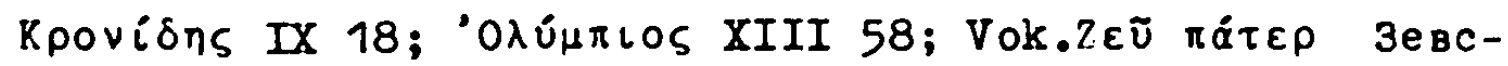

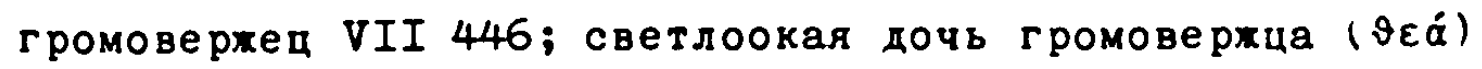

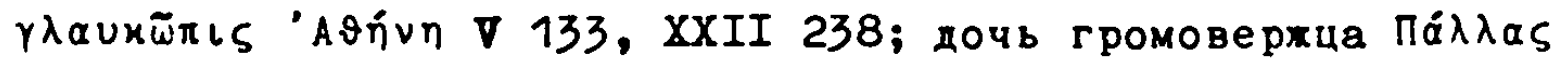

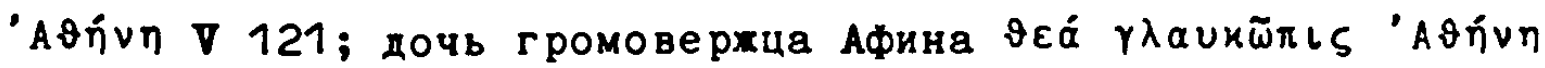
VIII 357; sinngemä $B$ eingeschoben I 423, VIII 144 u.v.a. Bel.bei Karamzin, Heym $M$.

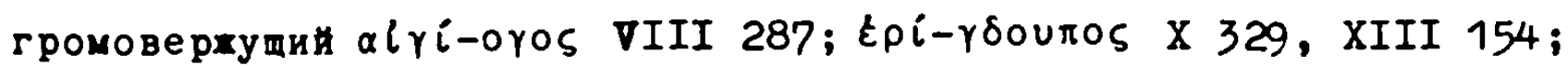

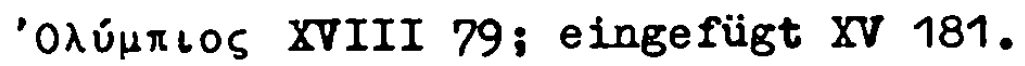

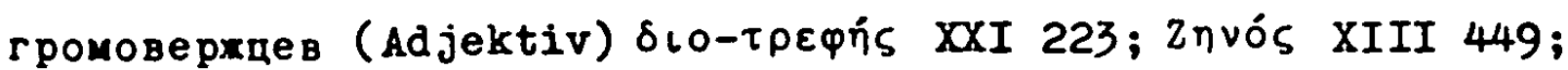

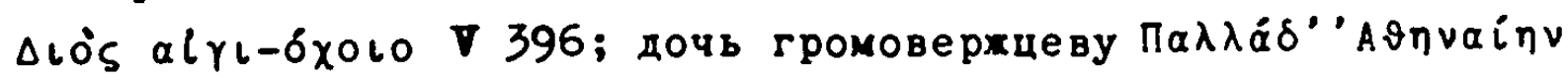
I 200.

громогласнын $\lambda$ เүús I 248, II 246; im Griech.verbal: громоглас-

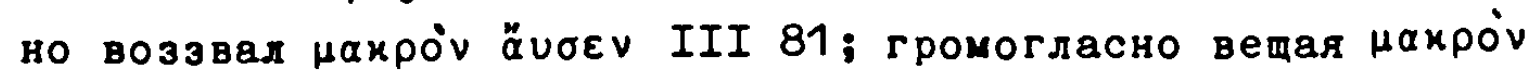




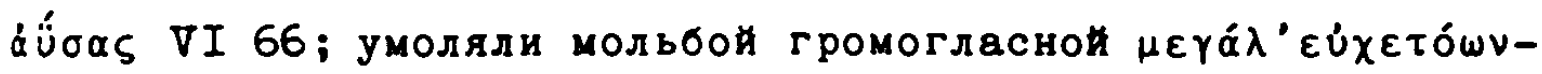
то ёкаотоS VIII 347; dafür XV 369: каждый...умолял громогласно. Bel.bei Srez.; Polik.: ßpovтофйvоs, Miklosich: ३povтóquvos; Ross.Cell.; Heym Ih,R; Slov. Ak.Ross. 1806.

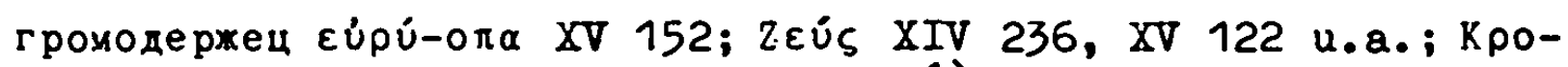
viwv XVII 269; eingefügt XIV 248 ${ }^{1)}$.

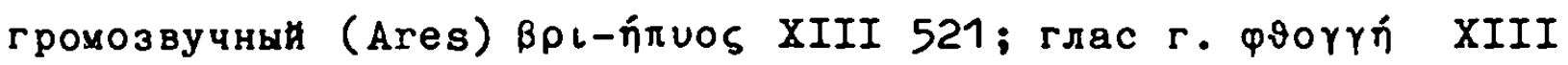
216; вопиял громозвучно накроу \&ن́баs XVI 268; крича громо-

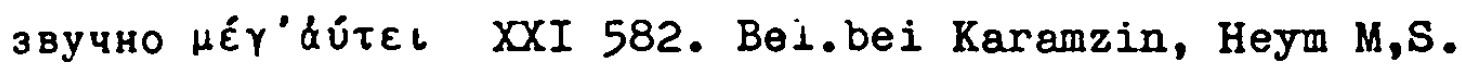
громомемущи: : г.зевс Kрovións Zeús VIII 141. BeL.in der Odysseeübers.von Jekimov, vgl.Jegunov S.70.

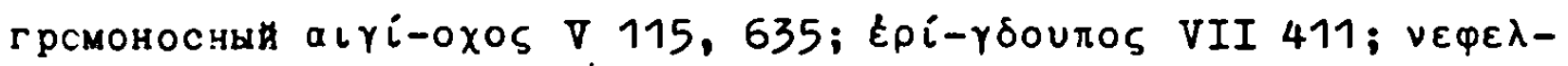

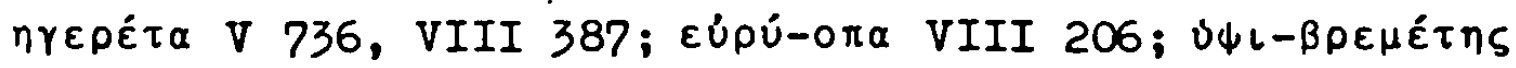

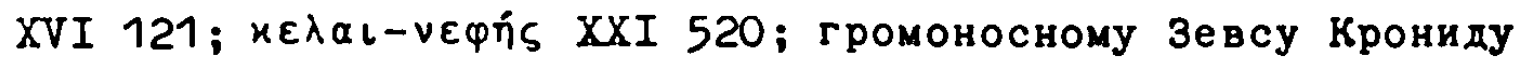

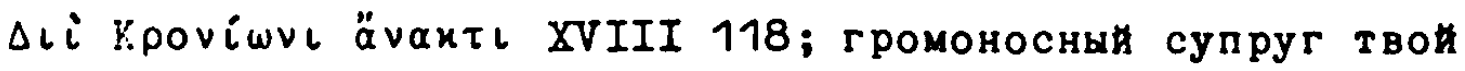

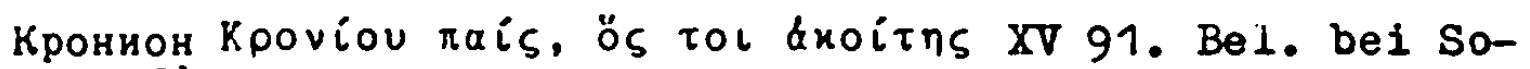
kolov ${ }^{2)}$.

густобрадын: лев $r$. $\lambda$ is tu-үévelos XV 275, XVII 109, XVIII

318. Bel.bei Srez.: $\delta a \sigma u-\pi \dot{\gamma} \omega v$.

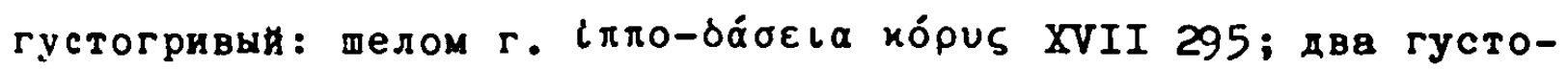

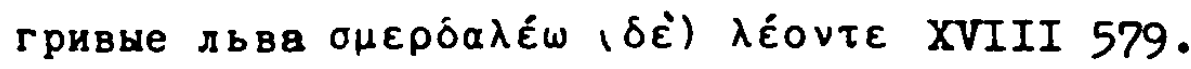

густокамншнын $\beta \alpha \vartheta \dot{v}-\sigma \chi 0 \iota$ ข०S IV 383.

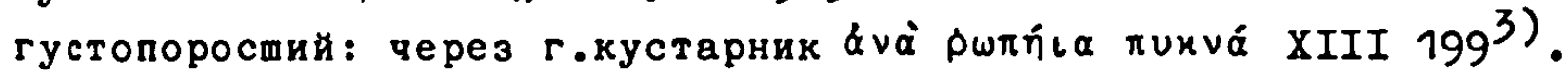

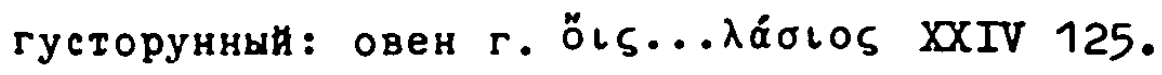

дазнобытнын: в давнобытное время потЕ XV 530.

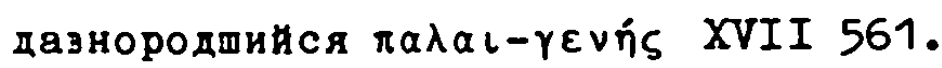

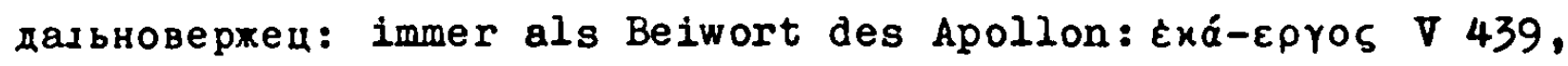

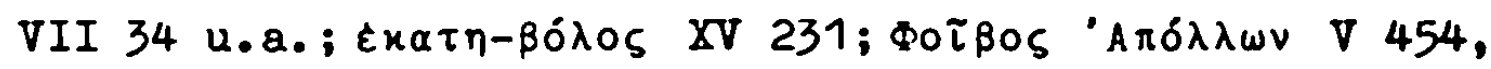

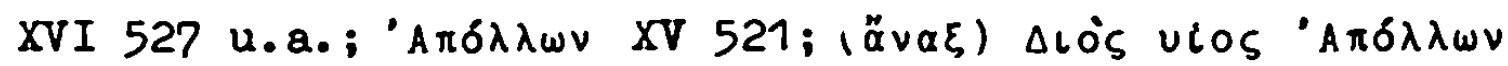

XVI 720, XX 82, 103.

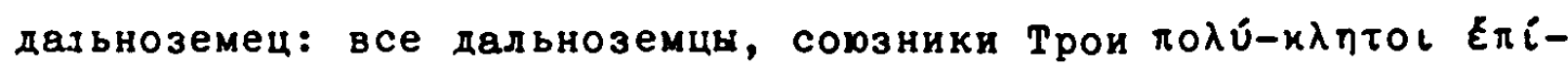
xoupol $X 420$.

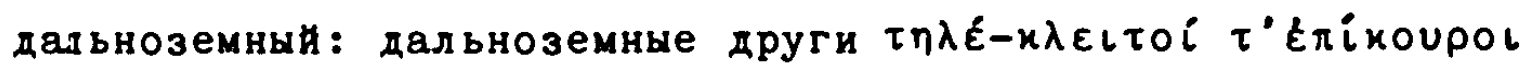

1.Bei Lomonosov ist belegt громодерхитель, vgl.HüttlWorth S.94, bei Kostrov rромодерхатедb, vgl.Jegmov S.96. 2.Kostrov prügt in seiner Homerübers. громоносящин, vgl. Jegunov S.95.

3. In Trediakovskijs Tilemachida findet sich густорослын, vgl.Hüttl-Worth S.95. 


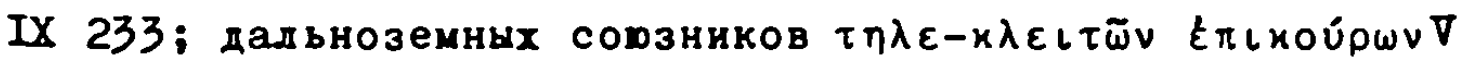
491; сорзников их дальноземных XI 564 .

дальнометкин: ни искусство, каким он, стрелец дальнометкин,

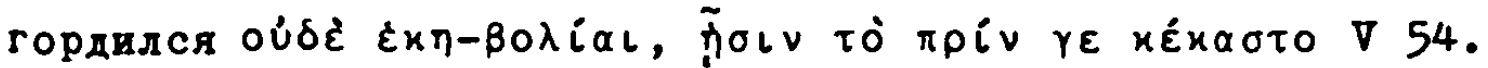

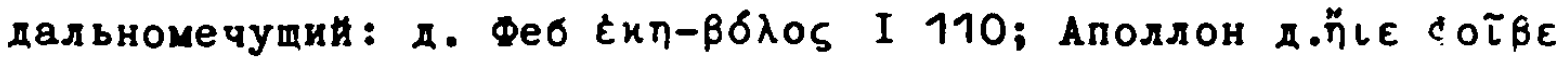

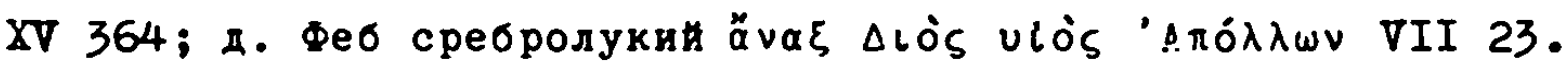

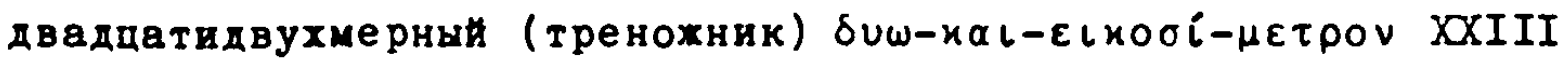
264.

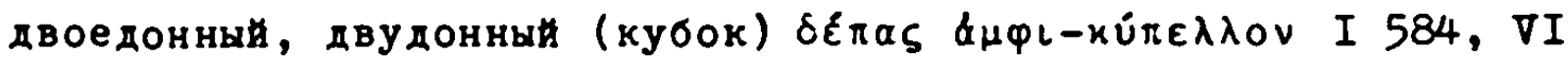

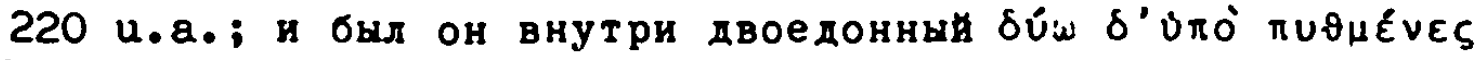
hoav XI 635. Bei Nordstet und Sokolov bel.двудоннын. двуконечны (пика) \&нфi-үuоs XIII 147. Bel.bei Heym M,R;

Slov.Ak.Ross.1809.

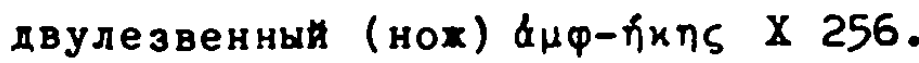

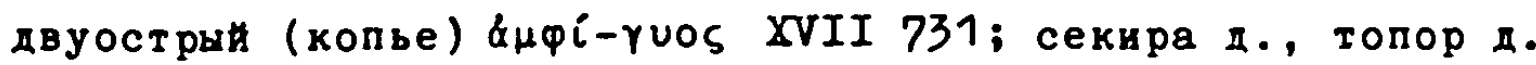

$\pi \varepsilon \lambda_{\varepsilon \times \cup S}$ XXIII 851, 882. двускладнын (покров) $\delta і-\pi \lambda \alpha \xi$ III 126.

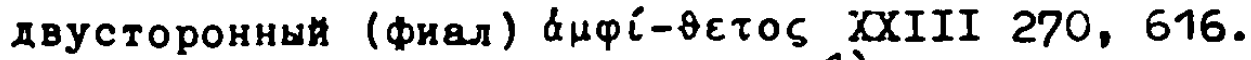

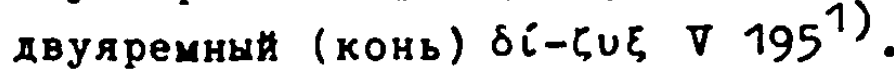

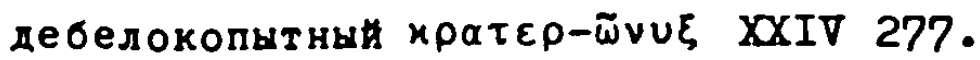

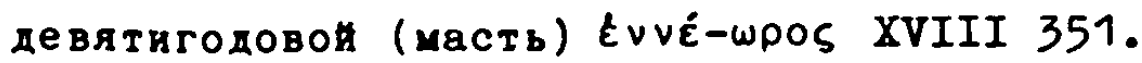

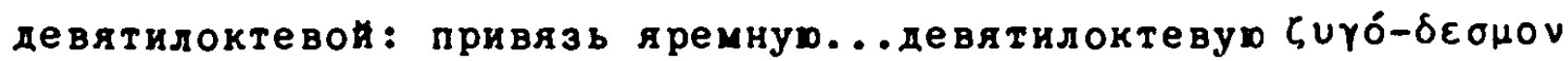

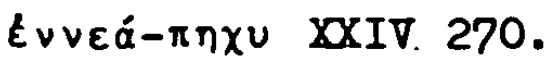
дерзхоотвахнын: ohne Entspr. im griech. Text, eingefügt als Beiwort zu Менетиев сын XVI 703. дерзосерды $\theta \rho \alpha \sigma u-x \alpha ́ \rho \delta\llcorner о \varsigma$ X 41. Bel.bei Miklosich: $\theta \rho \alpha \sigma u x \alpha ́ \rho-$

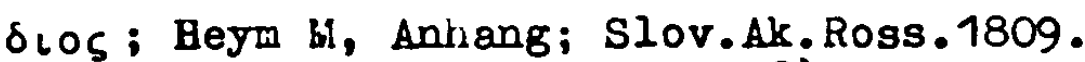

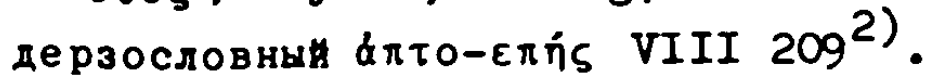

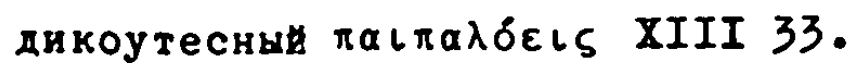

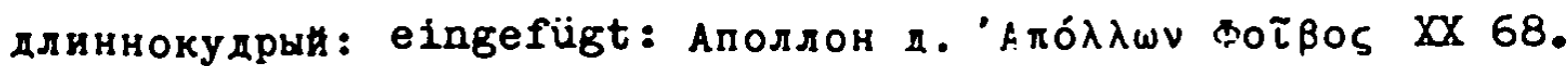

1.I.N.Hedvedeva schreibt a.a.0.S.31, двуяремны finde sich in den Drevnija rossijskija stichotvorenija von Kirła Danilov, 1804. In der 2. Auflage von 1818 konnte das Nort nicht gefunden werden. In dem der Verf. zur Verfügung stehenden Exemplar fehlen allerdin̈̈s die Seiten 313 320, doch enthalten gerade sie Dichtungen, die in der Ausgabe von 1804 noch nicht aufgenommen waren.

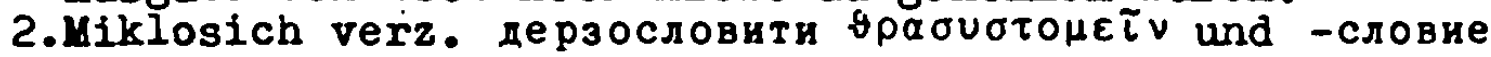
sermo audax. 
длиннфодежныи: Beiwort der Proerinnen $\varepsilon \lambda x \varepsilon \sigma i-\pi \varepsilon \pi \lambda \circ \varsigma$ VI 442, XXII 105.

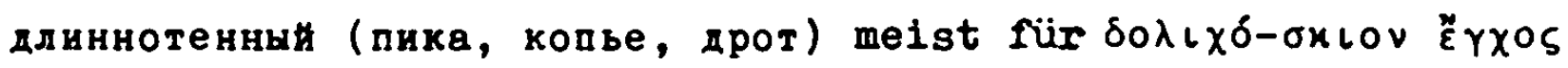

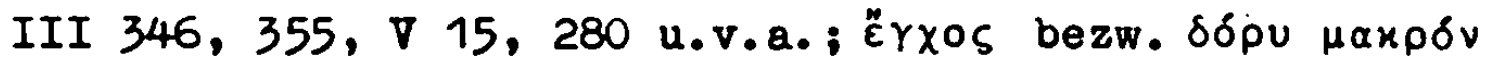

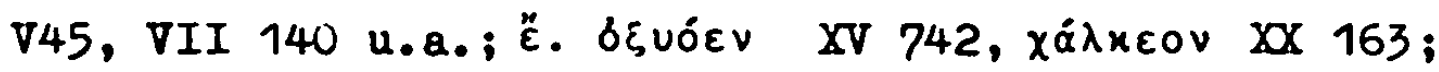
sinngemüB eingefügt XI 108.

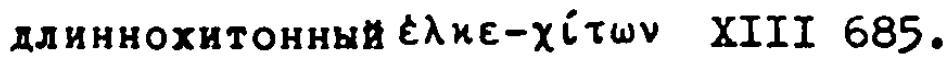

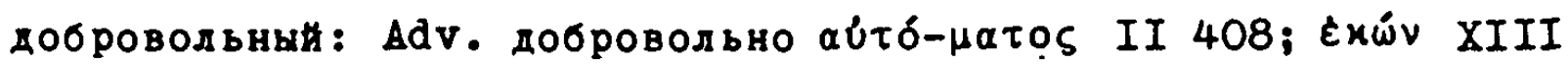

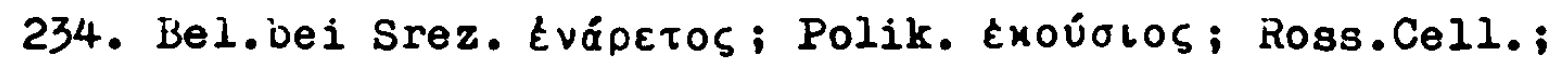
Heym $\mathrm{M}, \mathrm{K}$; Slov.AK.Ross.1809.

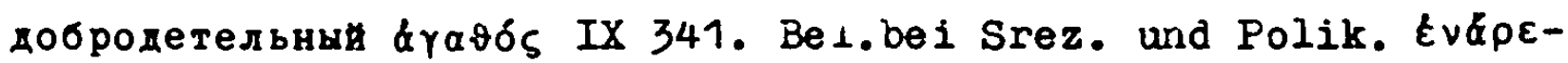

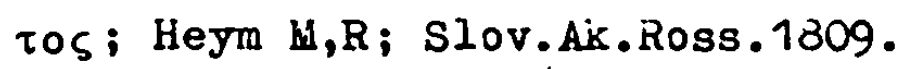

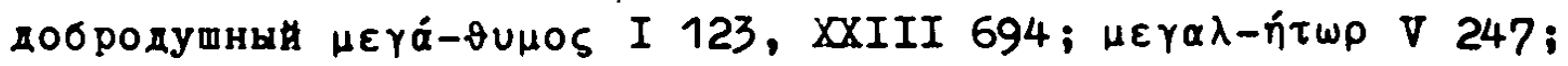

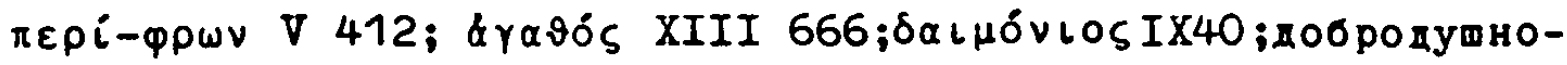

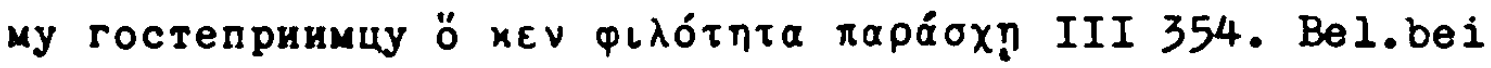

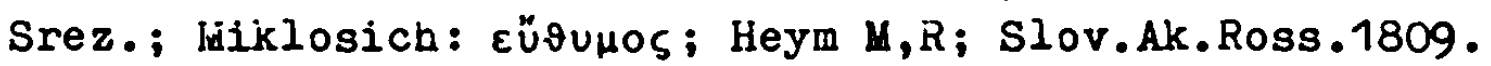

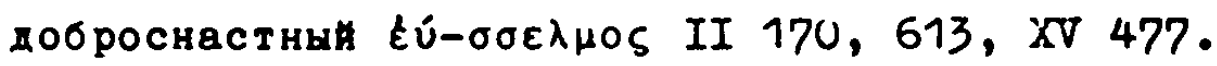

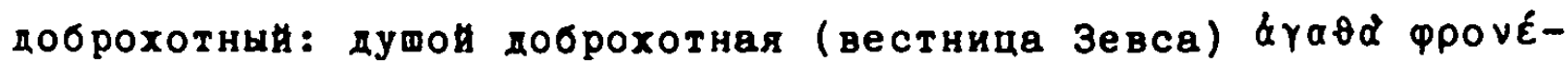

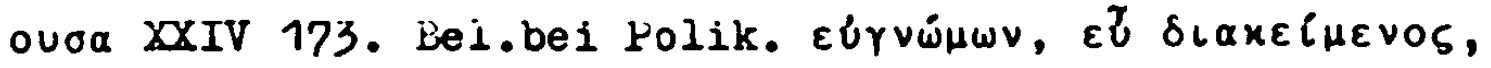

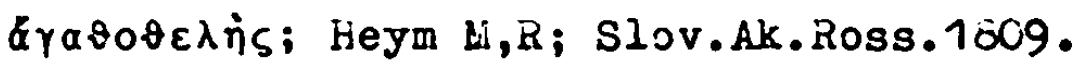

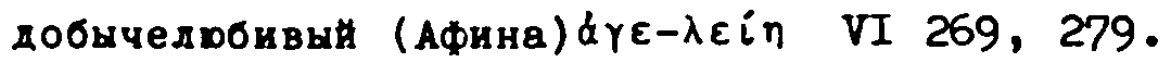

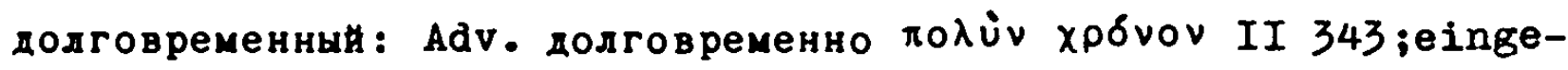

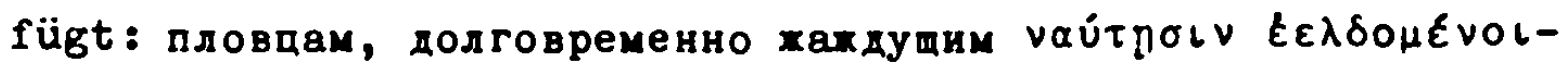
olv VII 4. Bel.bei Srez. uaxpós; Ross.Cell.; Nordstet;

Eeym Li, R; Slov.AK.Ross.1309.

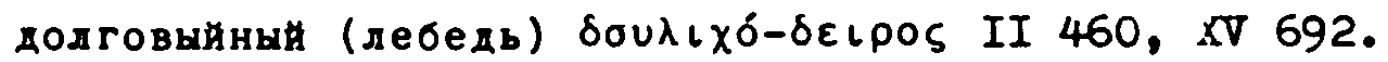

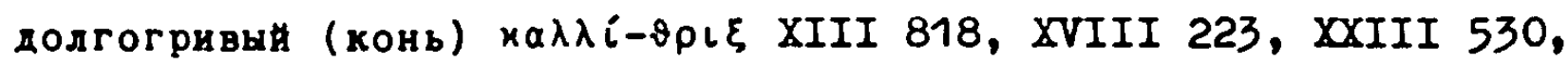
$\varepsilon \dot{u}-\vartheta \rho \iota \xi$ XXIII 13; mit anderer Entspr. $\dot{\omega} x u ́ s$ XVIII 244. Bel. bei Nordstet; Heym M; im Volkslied: Sobolevskij VII Nr.24. долгохалын: восемь...изомреннейих стрел долгохалых таии-

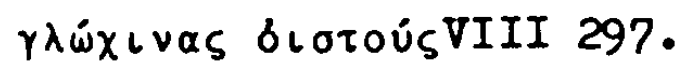

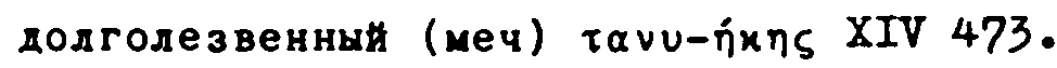

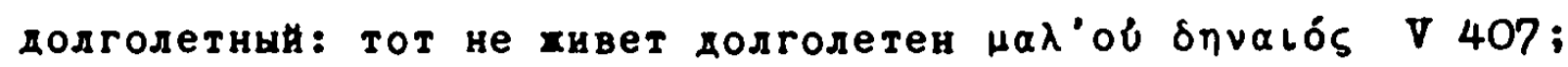

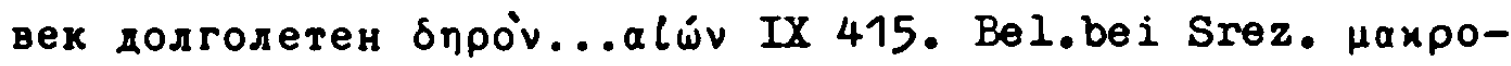

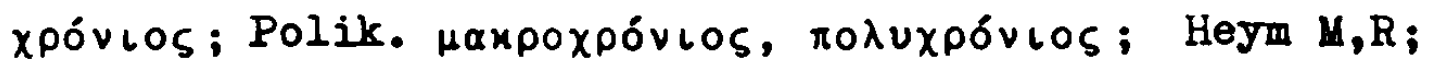
Slov.Ak.Ross. 1809 .

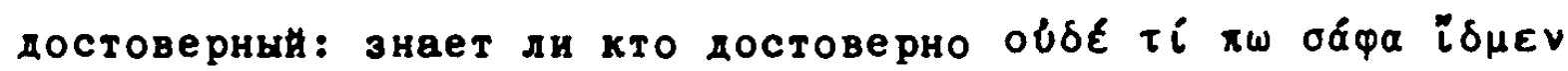

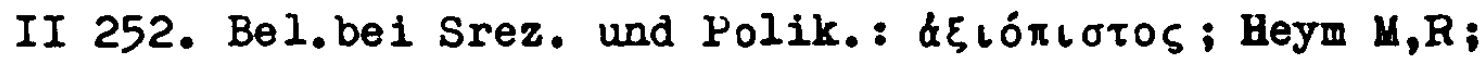


Slov.Ak.Rioss.10̈09.

досточуднын : eingefü̈t XX 267. Bel.bei Srez.; Polik.: $\alpha \xi\llcorner\alpha \dot{\alpha}-$

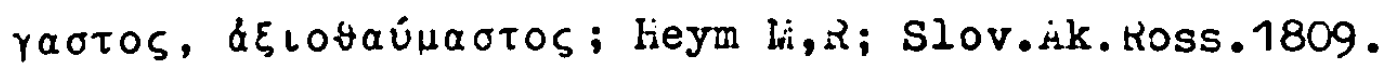

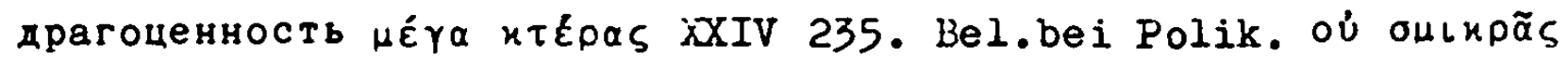

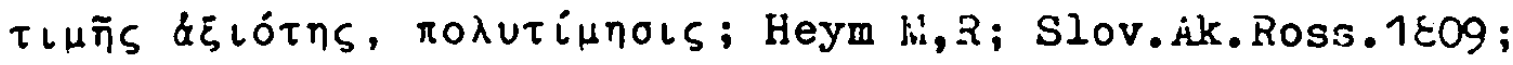

in der Volisdichtung: joboievskij I sir.148, 375 u.a.

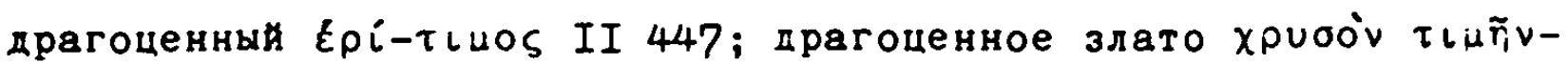

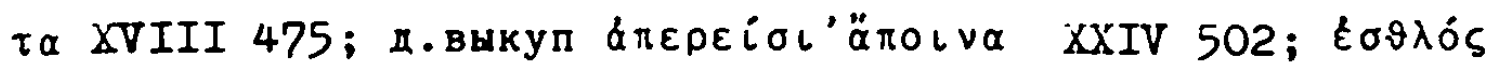

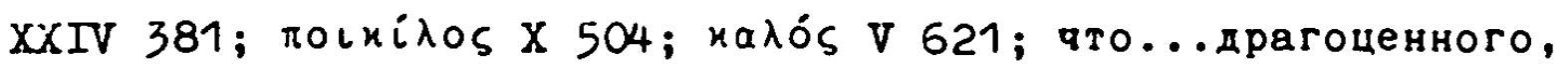

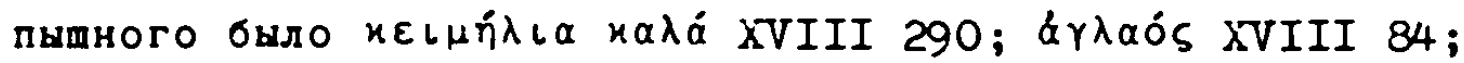

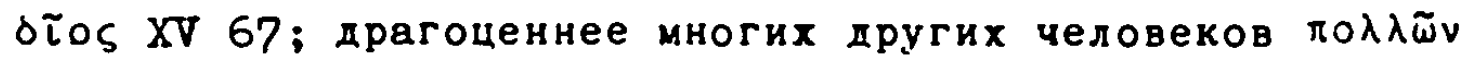

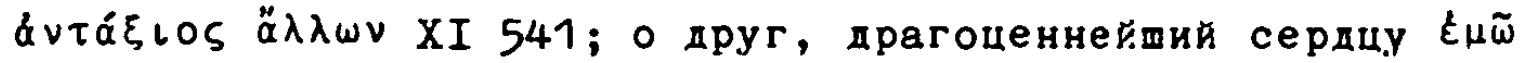

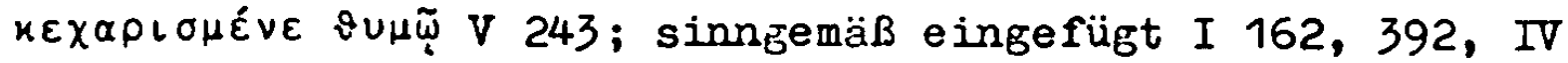

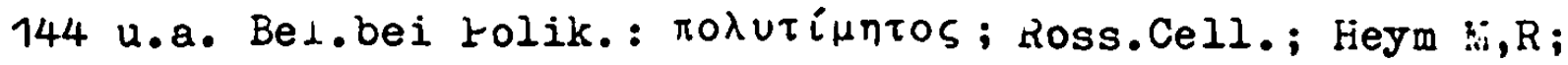
Slov.Ak.Ross.1809; in den Bylinei, Hilferding 61, 92.

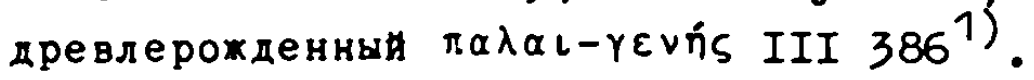

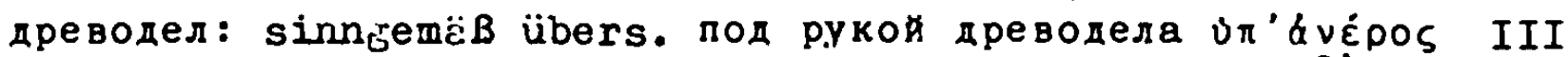

61. Вel.bei itordstet; rieym $\mathrm{H}, \mathrm{R}$ (neben древоделя) ${ }^{2)}$.

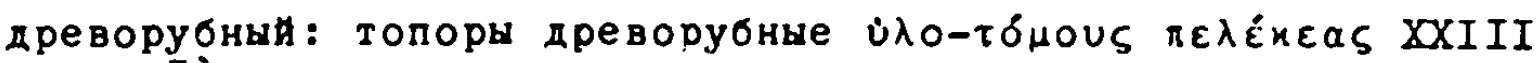
$144^{3)}$.

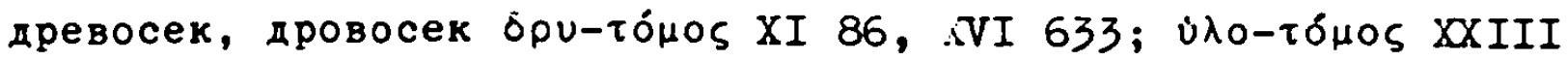

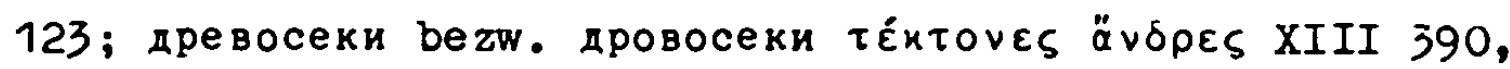
XVI 483. Древосек ist bel.in Slov.Ak.Ross.1809; Heym $S$; bei Sokolov; дровосек in koss.Cell.; Heißmann; reym $\mathrm{H}, \mathrm{R}, \mathrm{S}$; Slov.Ak.Ross.18094).

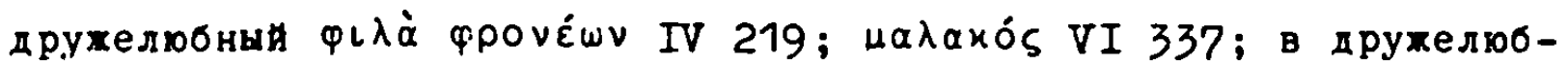

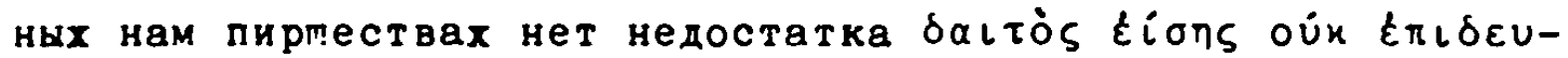

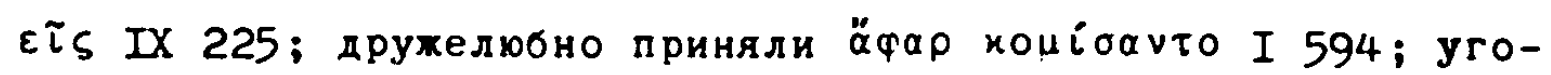

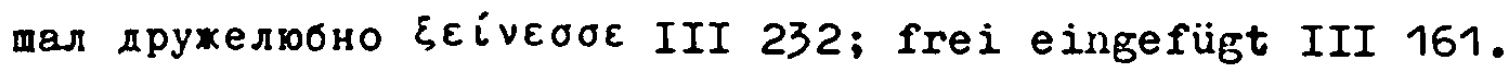
Bel.in Ross.Cell.; Heyin hi,R; Slov.Ak.Ross.1809. дуговерхин (судно) коршиіs XX 1 .

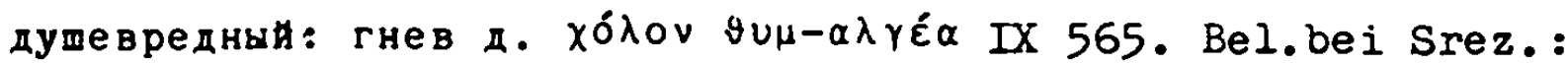
$\cup \times \circ \beta \lambda \alpha \beta \eta$ s; heym ii,R; Slov.Ak.Ross.1809.

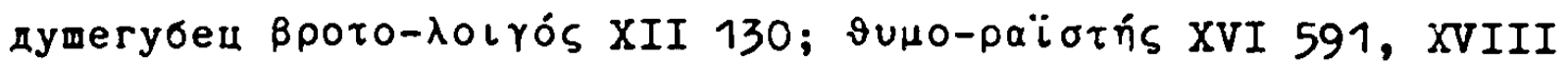

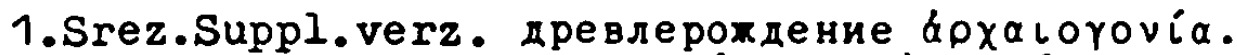

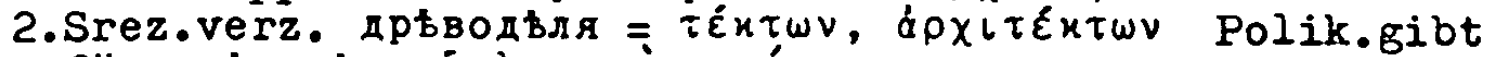

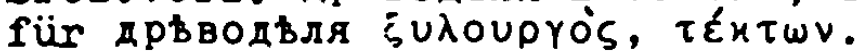

3. Bei hilferding, S.553, findet sich топоры дроворубнше.

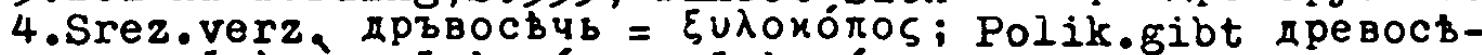

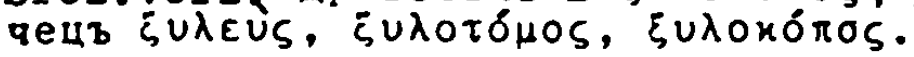


220; für $\chi \alpha$ á $\lambda x \varepsilon 05$ als Beiwort des Ares VII 146; sinngemäB

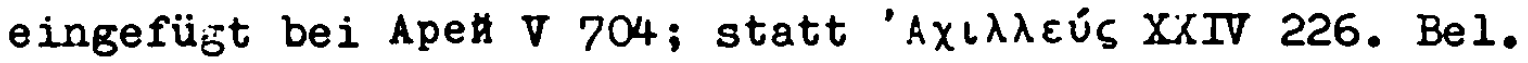
bei Srez.; Ross.Cell.; Heym H,R; Slov.Ak.Ross.1809. душегубның (смерть) จино-раїоти́s XVI 414, 580. Bel.bei Srez.;

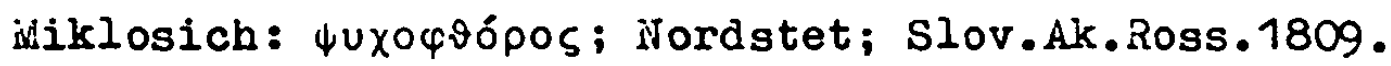

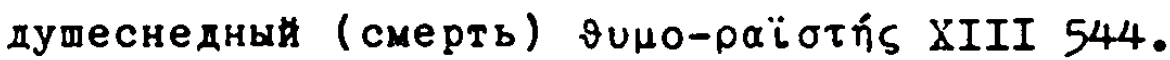

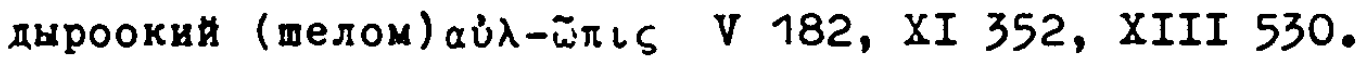

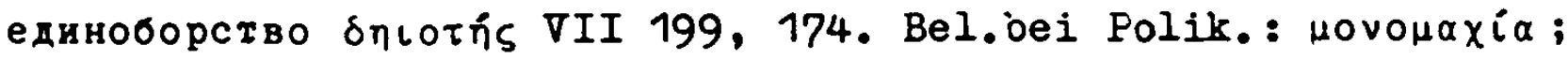

Nordstet; Heym $\mathrm{k}, \mathrm{R} ;$ SIov.Ak.Ross.1809.

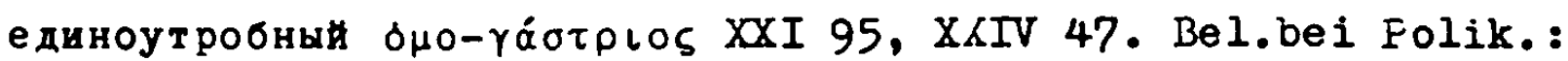

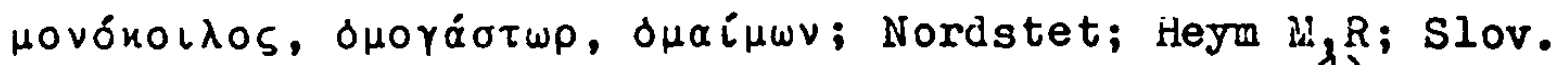
Ak. Rloss.1809; im russ. Märchen, Afanas'ev II $203^{(1)}$.

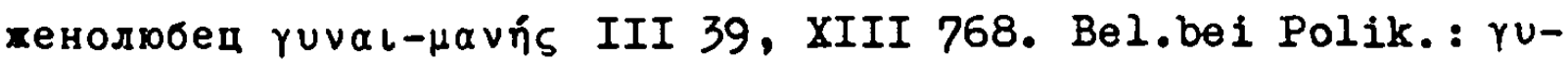

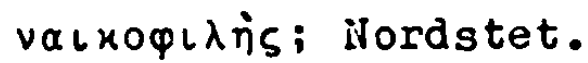

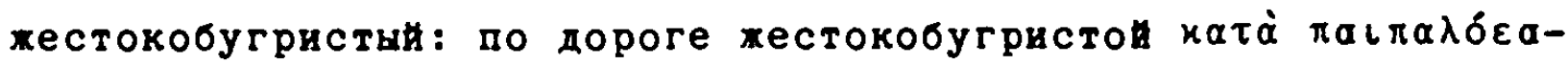

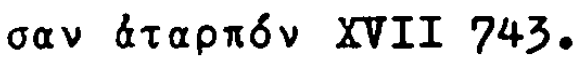

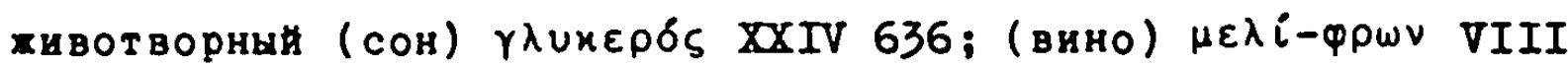

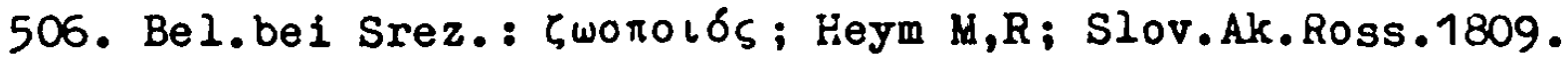

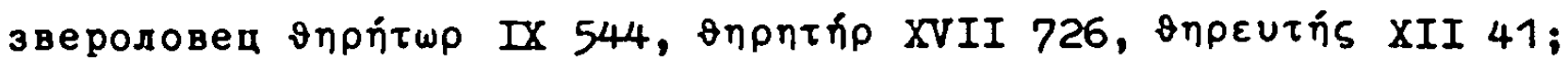

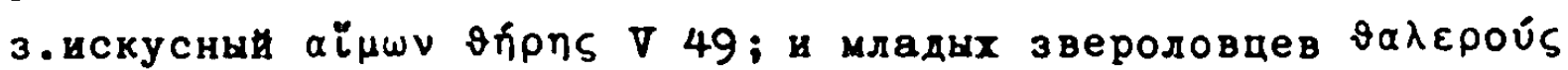

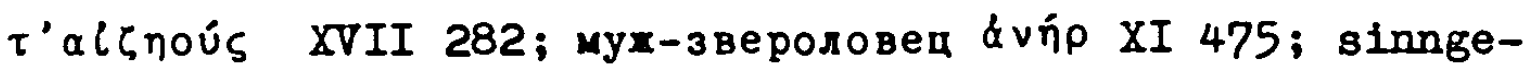
mӓß eingefügt XI 418. Bel.bei Nordstet (neben зверолов) ${ }^{2}$ ). звонкогласнй $\lambda \iota \gamma \dot{-\varphi \omega \nu о \varsigma ~ X I X ~} 350$.

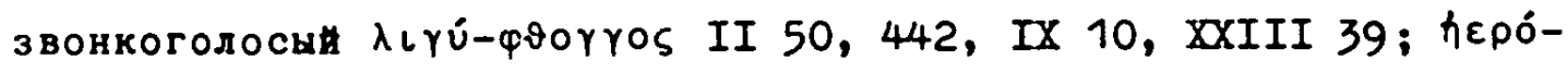
qwvos XVIII 505; $\lambda$ เrupós XIV 290. звонкорокочущи (лира)入ьүи́s XVIII 569.

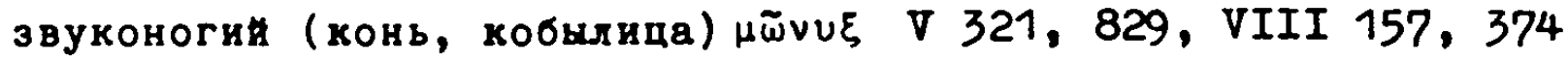

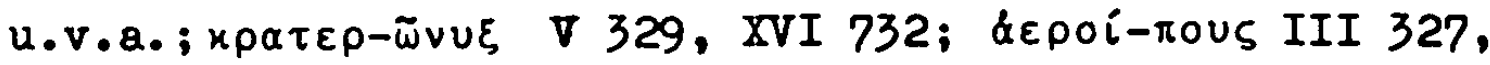
XXXIII 475.

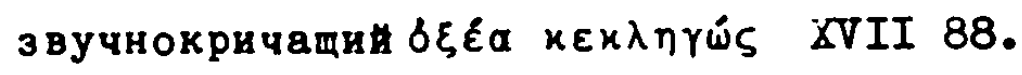

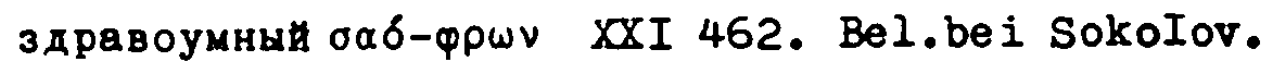
земледелед: sinngетӓß ӥbers. когда земледелед волов сопряхет

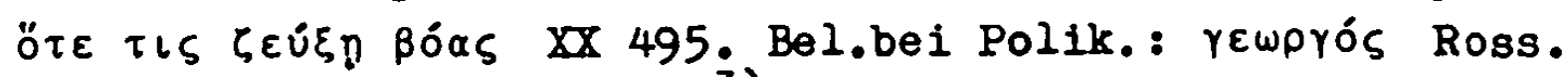
CeIl.; Nordstet; Heym $M_{2} s^{3}$.

1.Vgl.Dickenmann S.322.

2. Веуm $S$ und Sokolov verz. зверодов, Srez.Suppl. зверилоBeц xuvทrós.

3.Srez.verz. земледеля, -делатель. 


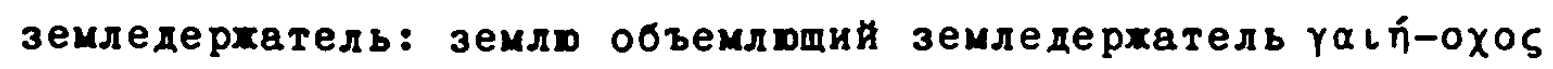
tvvooi-ralos IX 183.

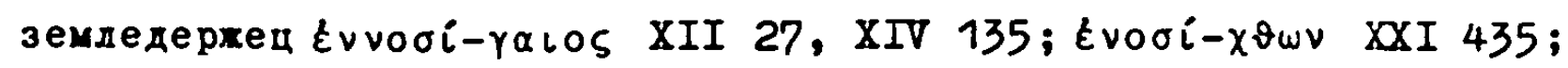

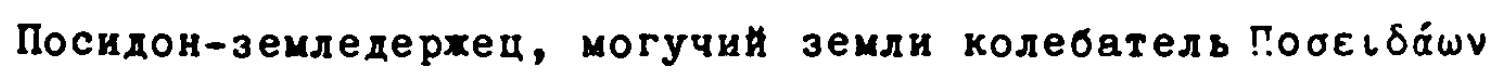

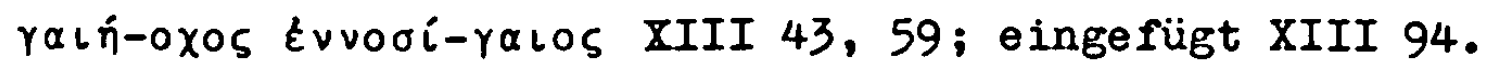
Bel.bei Srez.

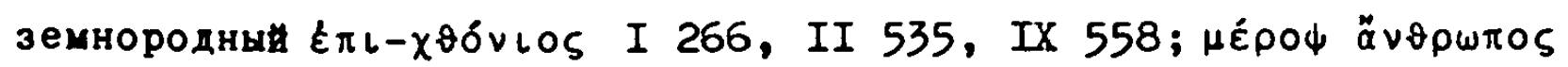

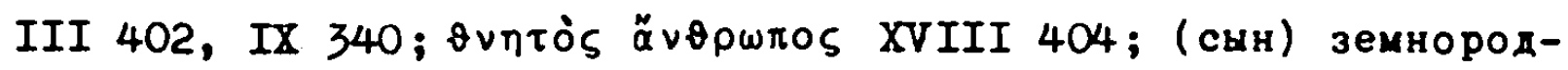

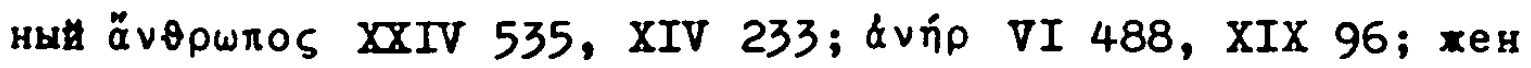

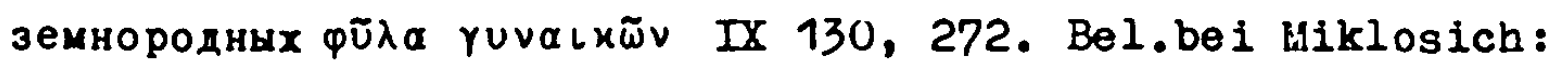
земльнородьнъ үпүєип́s; Srez.; Nordstet; Heym M,R; Slov.Ak. Ross.1809.

златоблещущи (кубок) хри́бєьоร XI 774. златобраздын (Artemis) хриб-ńvlos VI 205.

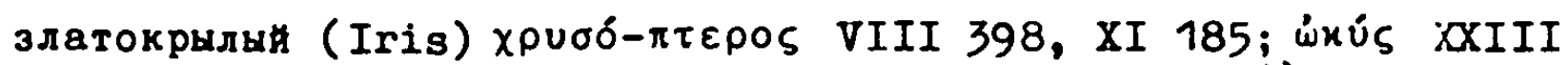

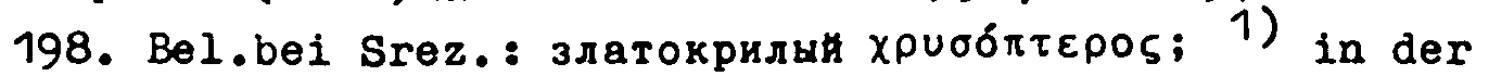

Volksdichtung: Sobolevskij VII Nr.504, -крыленькић IV Nr. 157; im Märchen: Afanas'ev II $55^{2)}$.

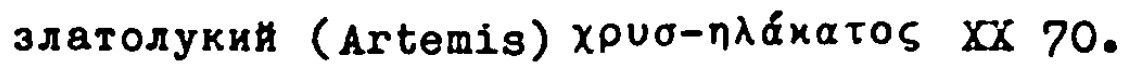
златомечны (Apollo) хриб-а́ороS XV 256.

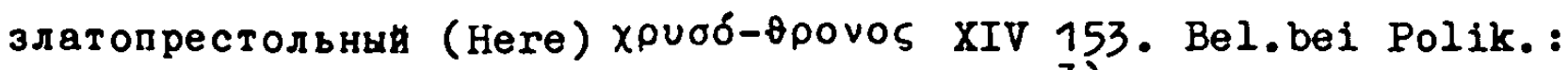

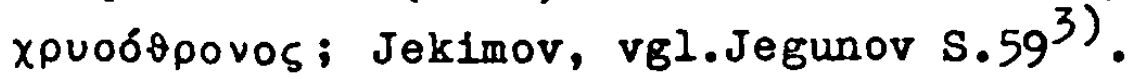

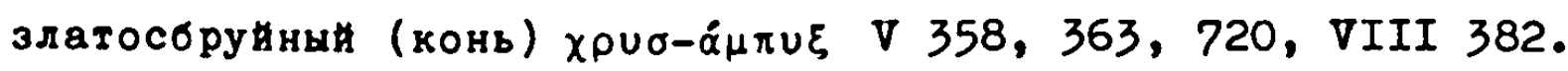

wordstet verz. златозбруннин.

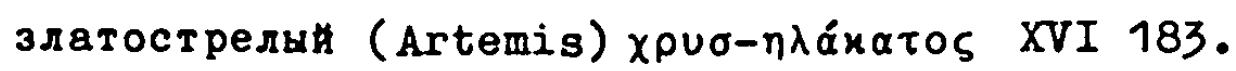

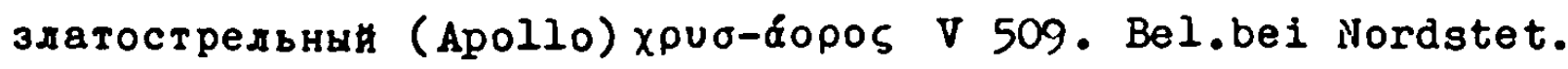

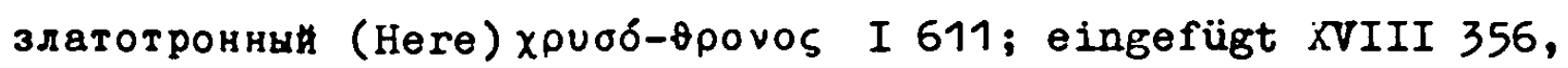

XX 114; mit anderer Entspr.: $\lambda \varepsilon u x-\omega ́ \lambda \varepsilon v 05$. I 195, 208. злачноцветущин: в злачноцветущих долинах тібєа поциंєvта XX 9.

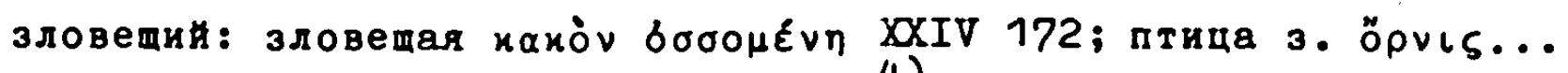
xaxós XXIV 219. Bel.bei Sokolov ${ }^{4)}$.

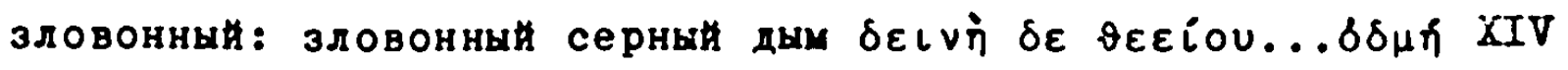

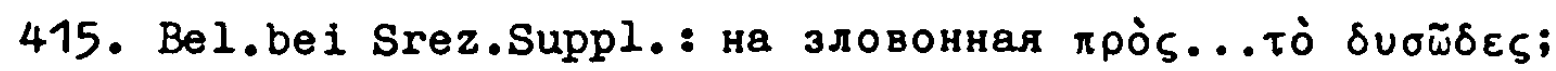
Nordstet; Heym M,R; Slov.Ak.Ross.1809.

1.Polik. und Nordstet verz. златокрилнын.

2.Vgl.Dickenmann S.230.

3.Kostrov prägt золотопрестольнни, vil.Jegunov S.95.

4.Nordstet verz. зловестник, зловестны, зловещание. 


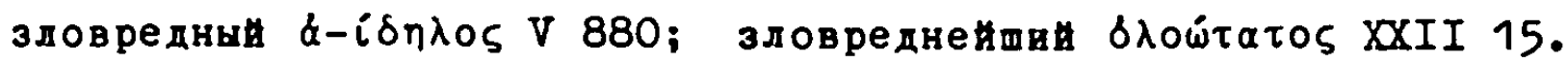

Bel.bei Nordstet; Heym H,R; Slov.Ak.Ross.1809.

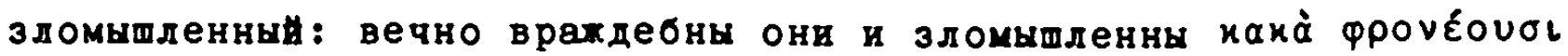

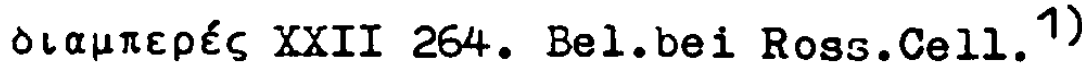

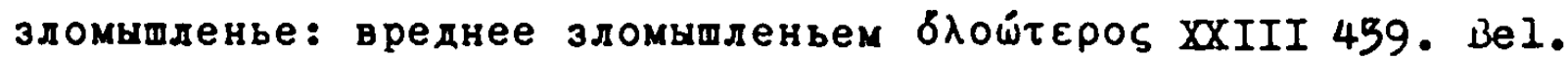
bei Polik.: зломышление како́vola.

злонамереннын: С злонамеренным в сердце коварством боло-фроvéovoa III 405. Bel.bei Heym Mi,R; Slov.Ak.Ross.1809. злополучие како́v XXIV 538, иака́ III 57; еingefügt: над моим

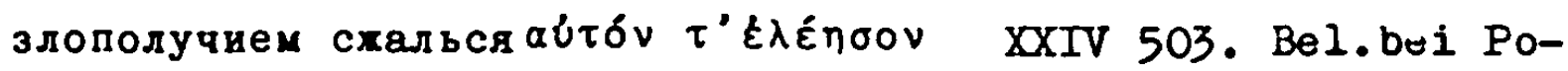

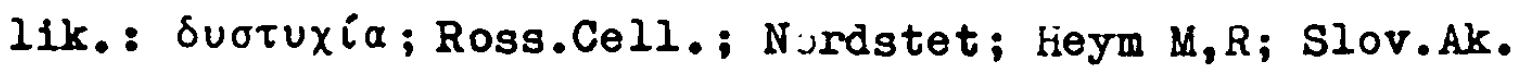
Ross. 1809 .

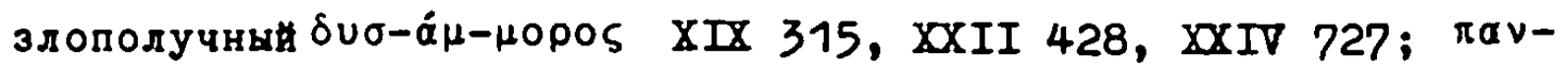

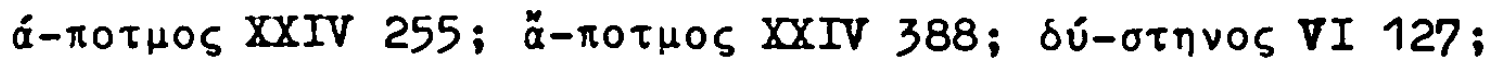

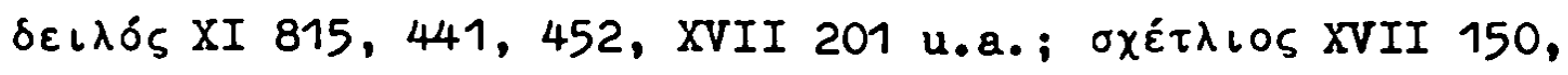

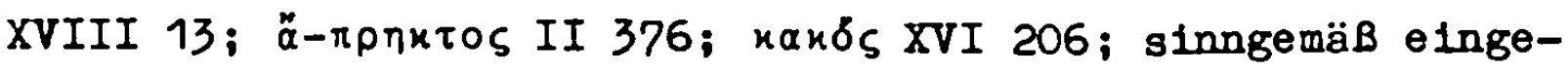

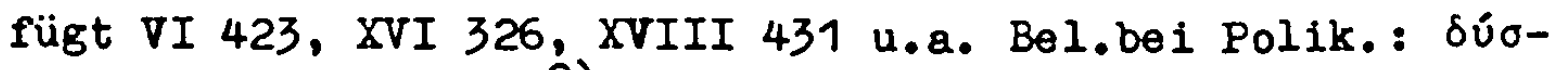

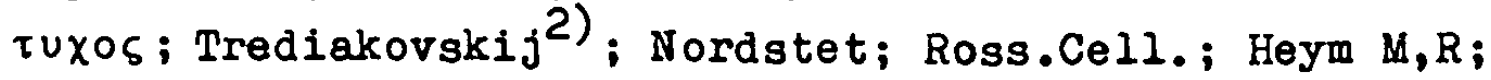
Slov.Ak.Ross. 1809.

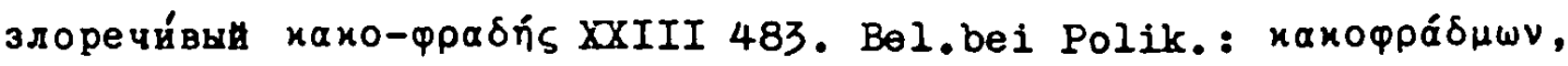

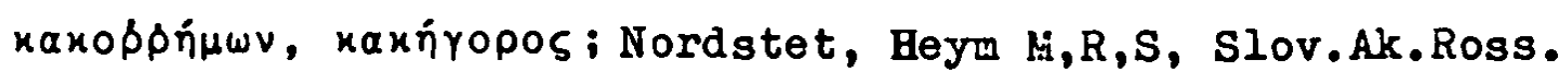
1809 geben sämtliche das iort in der Betonung злоречивын; Sokolov verz. Adj. злоре́чивын, aber Adverb злоречи́во.

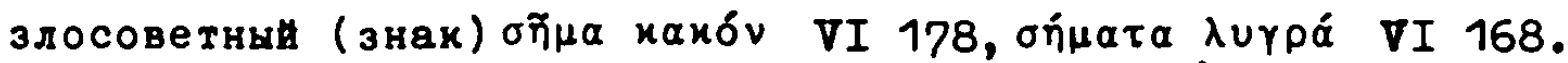

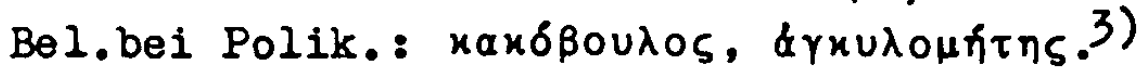

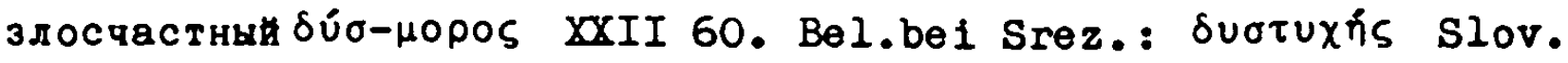
Ak.Ross.1809; Sokolov. Polik.verz. злочастнын иахо́ноцроS,

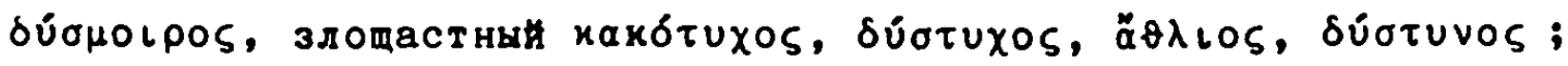
Heym $M, R$ scireibt злощастнын; Nordstet gibt злочастны, aber Adverb злочастно; in der Volkgdichtung findet sich злосчастнын bei Sobolevskij I Nr.297, II Nr.106 u.v.a., здочастнын bei K.Danilov S.209.

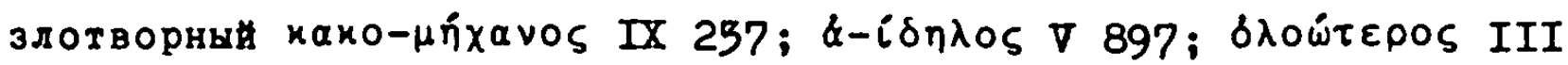

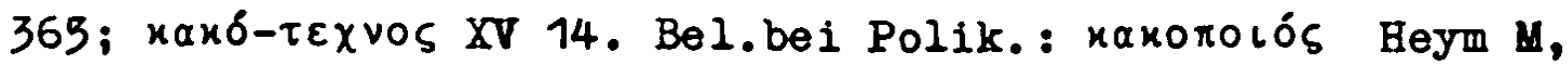

1.Srez.verz. зъломысльнын; Nordstet, Heym $M, R, S$, Sokolov verz. зломысленнын.

2. Vgl. TschiZewskij, ZslPh XVIII s.166.

3. Heym M,R,S und Slov.Ak.Ross.1809 verz.das Adjektiv nicht, aber злосоветие, -советнвк, -советовать. 
R; Slov.Ak.Ross.1809.

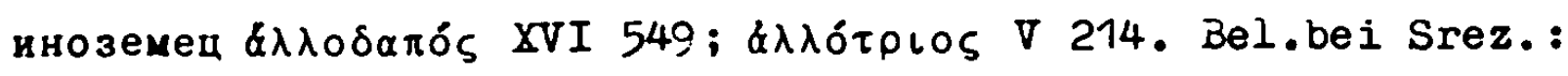

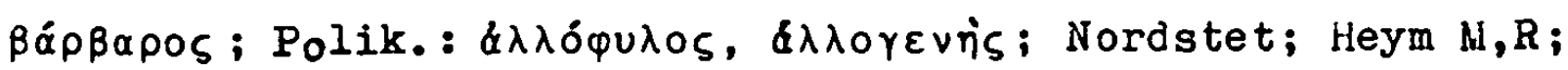
Slov. Ak.Ross. 1809 .

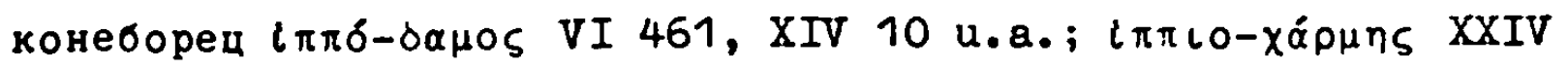

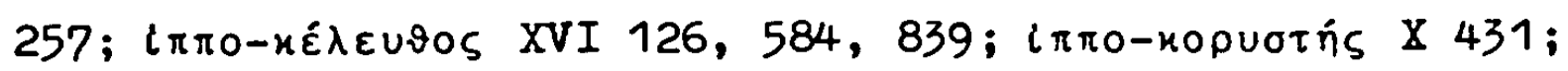
$i \pi \pi-\eta \lambda \dot{\alpha} \tau \alpha$ IV 387, VII 125, IX 581; $\pi \lambda \dot{\eta} \xi-\imath \pi \pi \circ \varsigma$ V 705; $i \pi \tau \delta \tau \alpha$

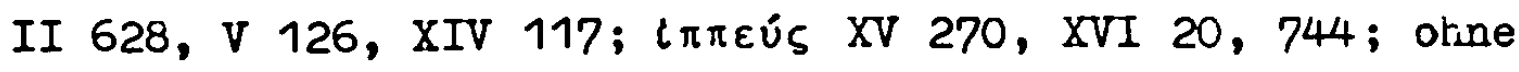

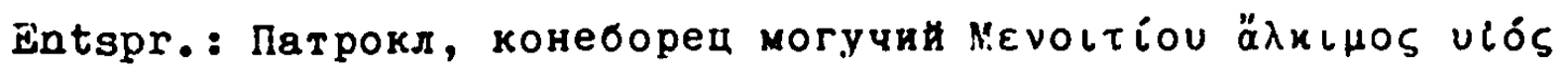
XVI 665.

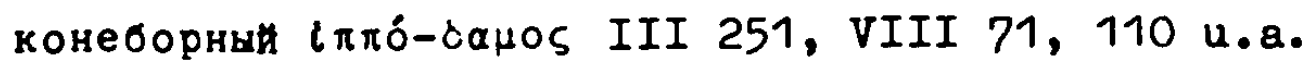
конеборственныи: einge fügt IX 220.

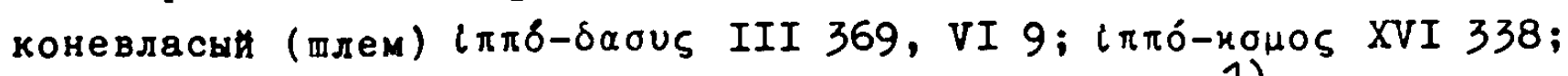
i $\pi \pi$-oup ᄂs XIX 382; eingefügt XI 351, XIII 577. 1)

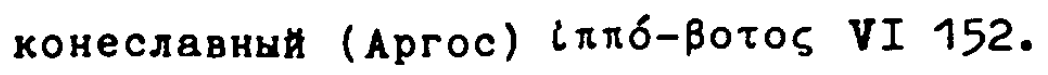
коннодоспешнын $(\pi \pi 0-к о р$ бот́丶 II 1 . копьеборец: oft verstärkt durch Adjektiva, z.В. могучии, ги-

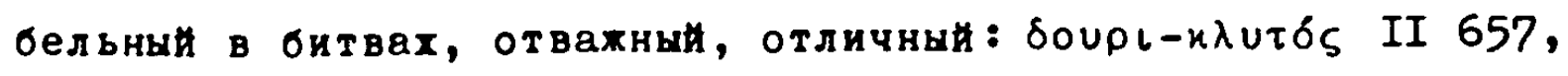

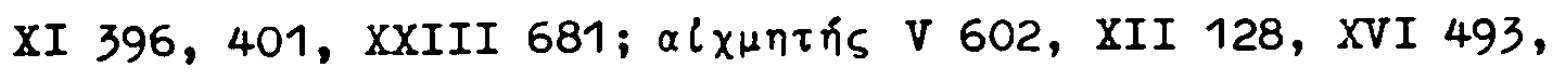

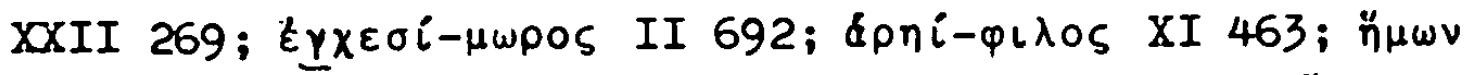
XXIII 886; freier übers.: копьеборец славнении हैүХЕц...

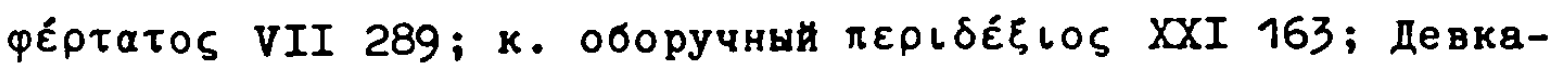

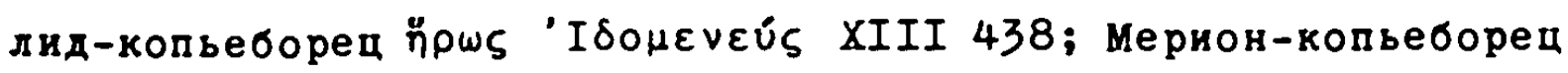

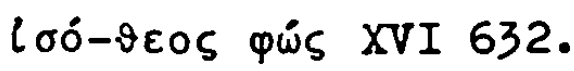

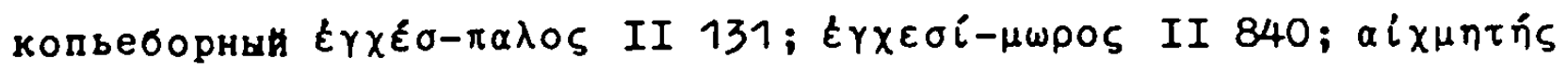
II 846 .

копьеборство: и ахенских мухе копьеборством всех превышал $и \varepsilon-$

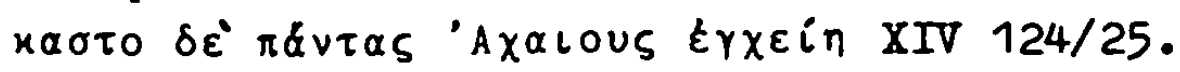

копьеметед: frei übers.: но копьеметец отличны мех гелленов

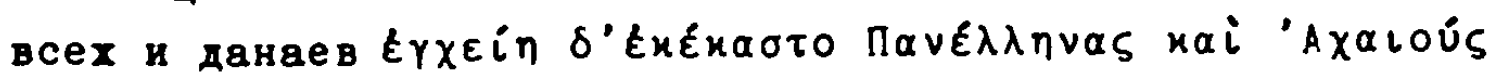
II 530 .

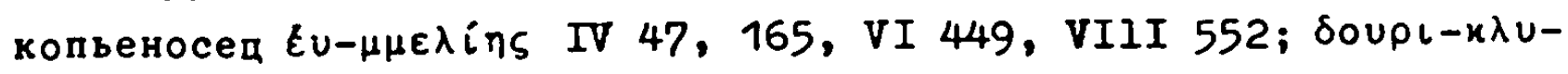

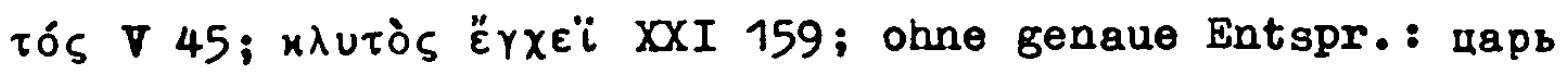

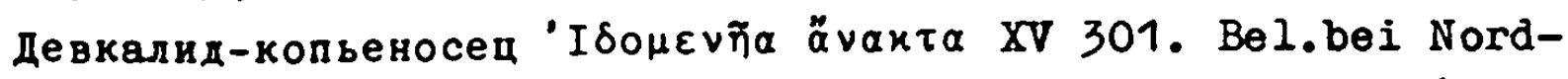

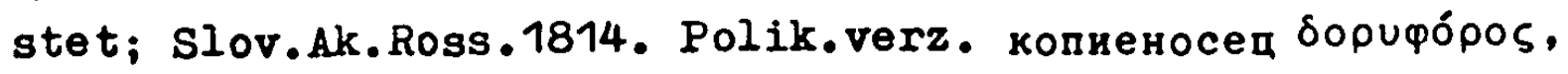

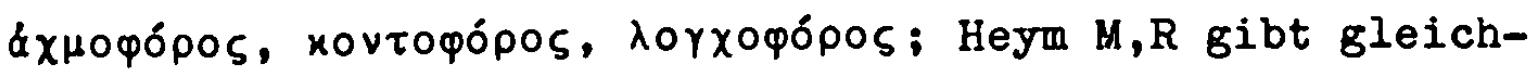

1.In der Homerübers.von Popov ist belegt коневласати, vgl.Jegunov S.198. 
fells копиеносец.

копьеноснын: ohne genaue Entspr.: герон Полипет копьеноснын

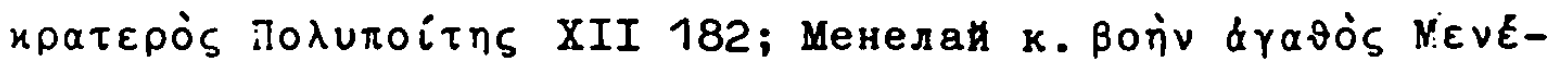
naos VI 37; eingefügt XXIII 293.

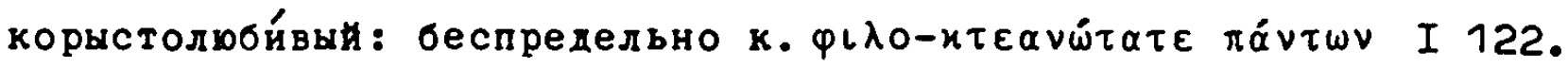
Bel.bei Ross.Cell.; Nordstet; Heym M; Slov.Ak.Ross.1814;

Неуm $\mathrm{R}$ verz.корыстоль́бивын̆.

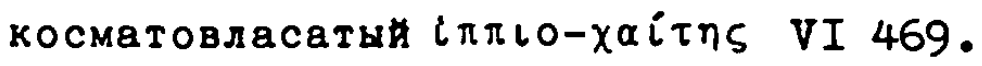
косогласы (Ферсит): Был косоглас, хромоног фодио̆

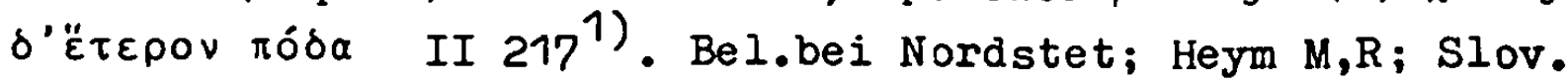
Ak.Ross. 1814 . красивоколесны $\varepsilon \dot{-}-\tau$ рохоऽ VIII 438 (man beachte die etymolo-

gische Figur в колеснице красивоколеснон!).

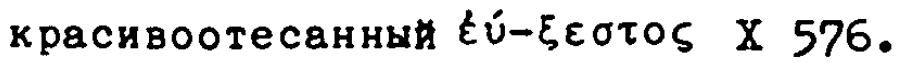
красивоплетены $\varepsilon \dot{U}-\pi \lambda \varepsilon к \tau о 5$ XXIII 335.

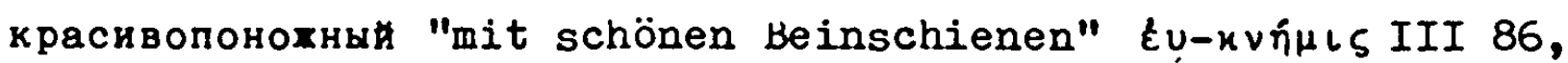

VII 311, XVII 370; $i \pi \pi \delta-\delta \alpha \mu 05$ III 242.

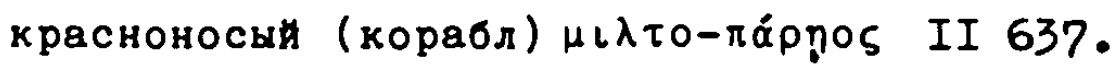
красноопоясаннын $\varepsilon \dot{u}-\zeta \omega \vee о 5$ I 429, IX $366 ; \beta \alpha \theta \dot{v}-\zeta \omega$; красноречие: frei übers.: если при нем в красноречии спорила

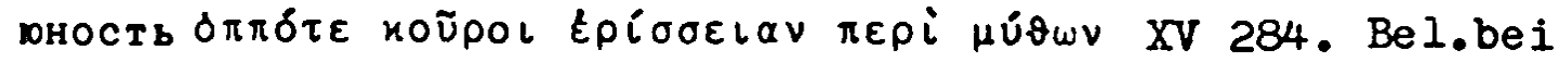

WeiBmann; Nordstet; Heym M,R; Slov.Ak.Ross.1814.

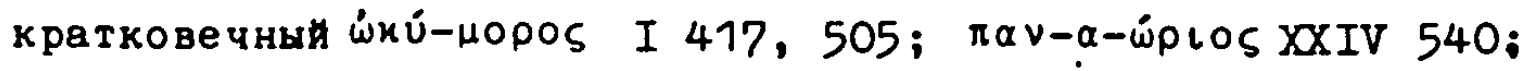

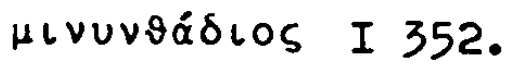

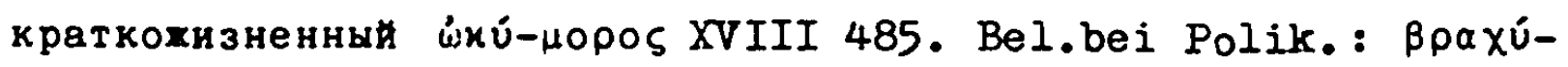

Blos; Heym M,R; Slov.Ak.Ross. 1814 .

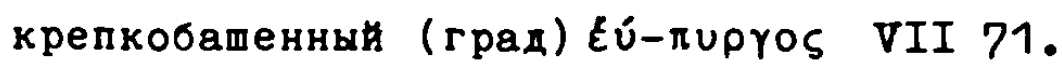
крепкоброннын Эшрпкті́s XII 317, XV 689.

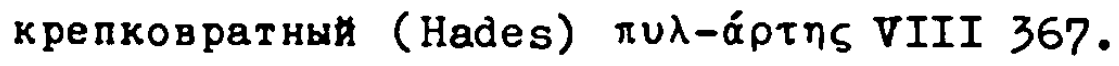

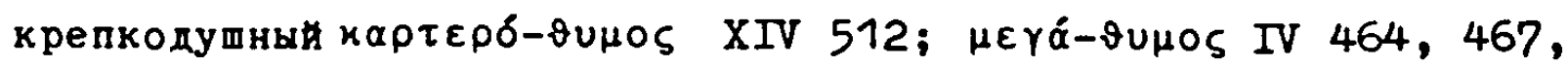

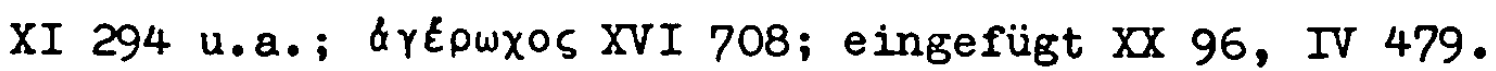

Bel.bei Srez.und Miklosich.

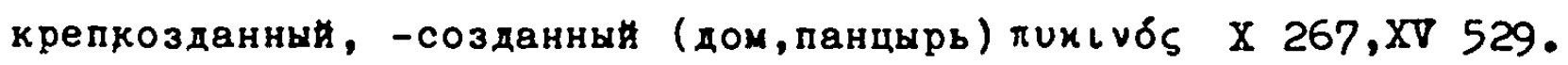

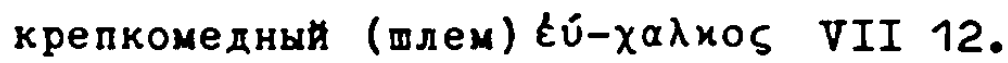
крепкоснастны (корабль) हиं-бовлнољ XVI 1. крепкосозданны s.u. крепкозданнын.

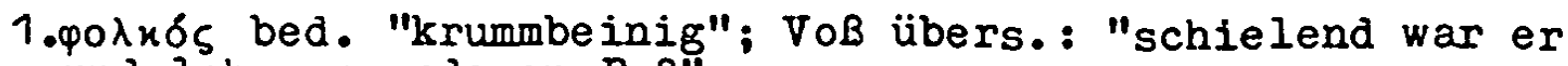
und lahm am anderen Fuß". 


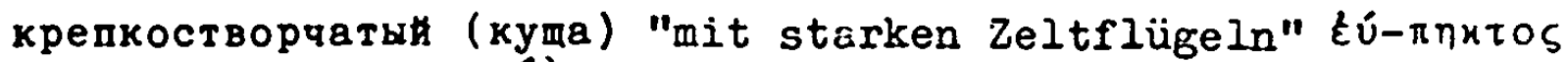
IX 663, XXIV 675 ${ }^{1)}$.

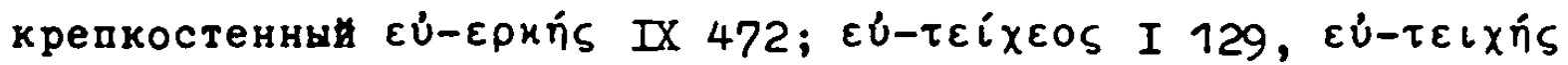

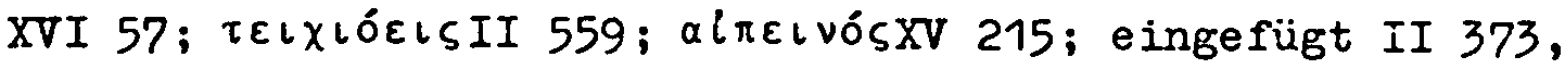
IV 239, 290, XXII 381.

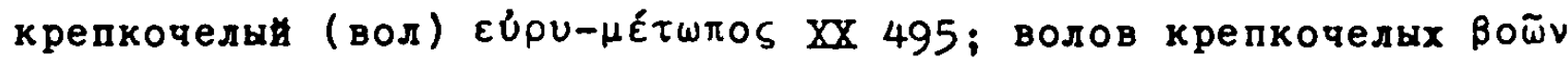

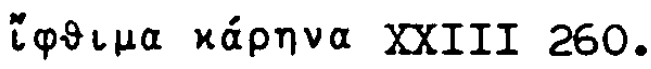

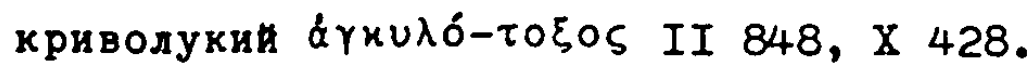

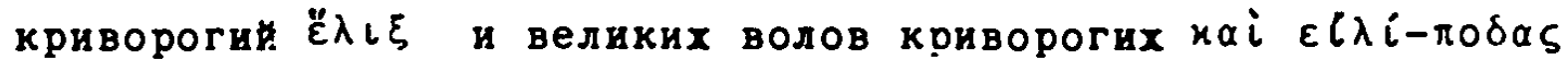

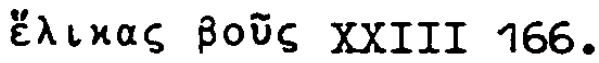

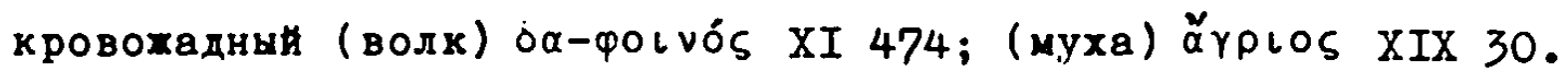

Bel.bei Heym M,R; Slov.Ak.Ross.1814.

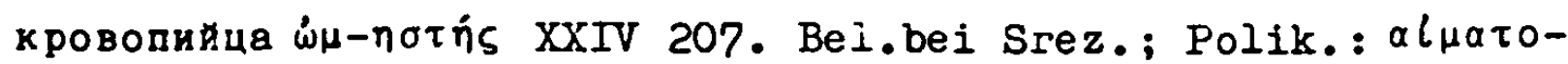
rótns Heym Li,R; Slov.Ak.Ross.1814.

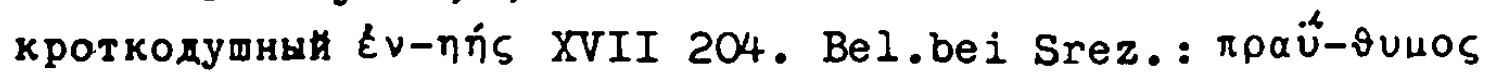

Heyin $M, R$; Slov.Ak.Ross.1814.

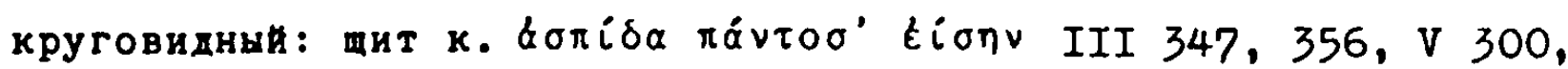

VII 250 u.v.a.; im Griech.verbal: и щитом заградил круго-

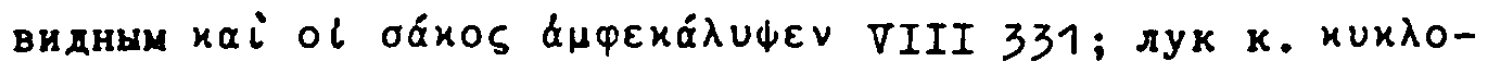

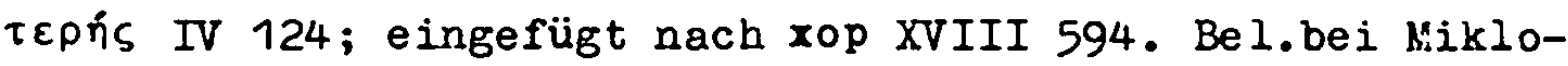
sich unà Sokolov.

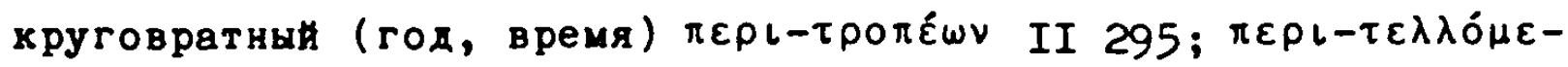
vos II 551, VIII 404, 418; eingefügt II 134, XXIV 765. кругозарны (стенв) $\pi \alpha \mu-ф \alpha \nu o ́ \omega \nu$ VIII 435.

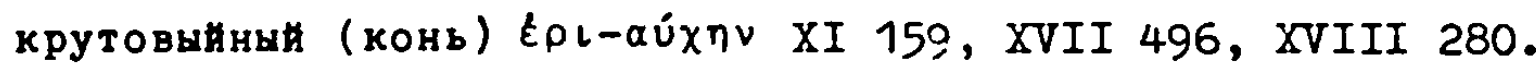
крутоносы (судно) коршVls II 392. круторогин ह̌ $\lambda\llcorner\xi$ XII 293, XV 633; $\varepsilon i \lambda i-\pi о \cup 5$ XV 548; (тяхелых)

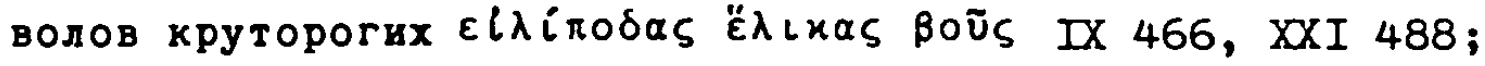
eingefügt V 556, VII 474. Bel.bei Sokolov; im Volkslied, Golovackij II 16, III Teil 2, 14.

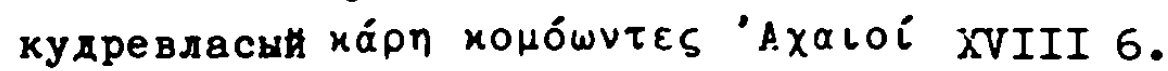

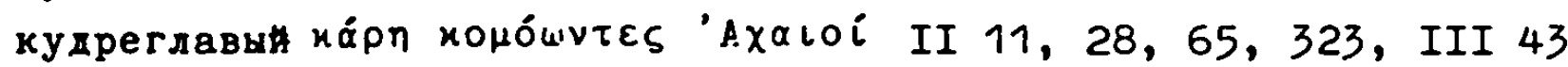

u.v.a.; eingefügt II 72 , VIII 414. легкодвихимын (щит) alódos VII 222 2 ).

1.I.W.liedvedeva schreibt a.a.0.S.31, крепкостворчатын finde sich in den Drevnija rossijskija stichotvorenija von K.Danilov, 1804. In der Ausgabe von 1818 konnte das Hort von der Verf.nicht gefunden werden. Vgl.Anm.zu двyяремнын.

2.Nordstet verz. легкодвихнын. 
легкоквтнын (воз) $\varepsilon \dot{u}-\tau$ рохоऽ XII 58, XXIV 266; mit anderer Entspr.: $\ell \dot{u}-\xi \varepsilon \sigma \tau 0 \varsigma$ XXIV 275. легкометнын: крылатых щитов легкометных $\lambda \alpha \iota \sigma \dot{\eta} \iota \alpha \ldots \pi \tau \varepsilon \rho o ́ \varepsilon v \tau \alpha$

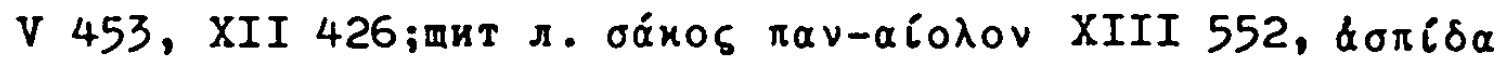

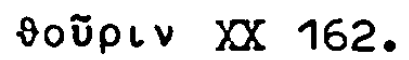

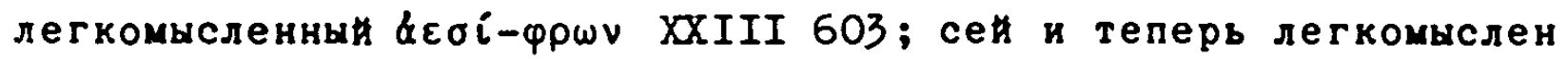

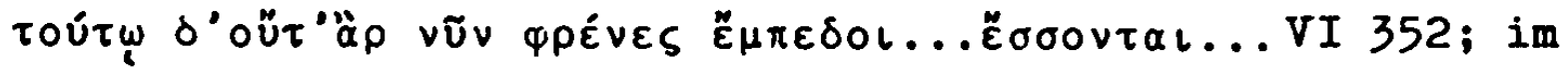
Griech.verbal: сердие люден̆ молодых легкомысленно, непо-

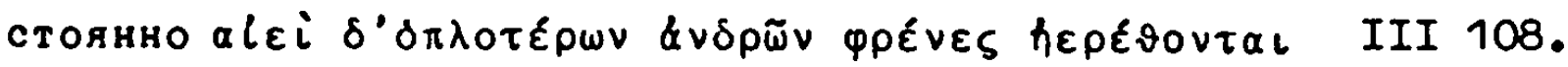
Bel.bei Weißmann; Ross.Cell.; Heym M,R; Slov.Ak.Ross.1814.

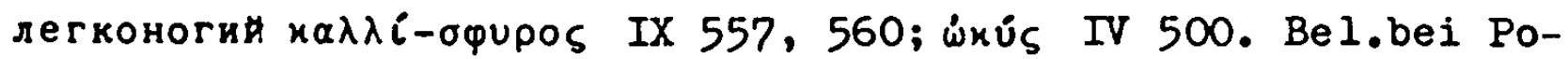

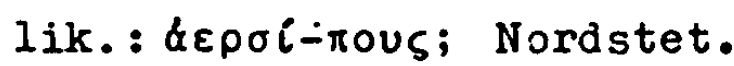

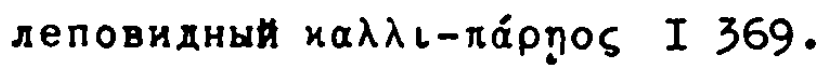
лепогривын $x \alpha \lambda \lambda i-\vartheta \rho\llcorner\xi$ XVII 624 . лепокормнын $\varepsilon \ddot{-}-\pi \rho u \mu \nu$ IV 248. лепокудрын tú-коноS I 36, III 329, IV 512 U.v.a.; $x \alpha \lambda \lambda_{\iota}-\pi \lambda \delta-$ канољ XIV 326, XX 207; sinngemїв eingefügt: лепокудрын Па-

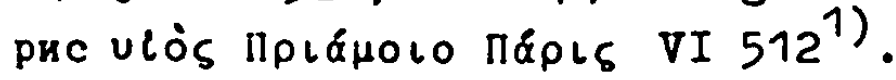
лепотронны $\varepsilon \dot{U}-\vartheta$ роvоऽ VIII 565.

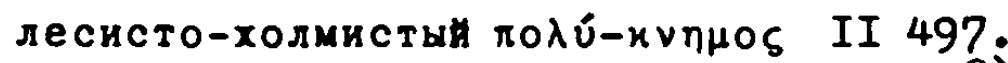

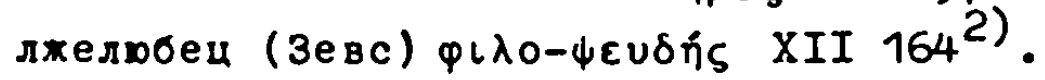

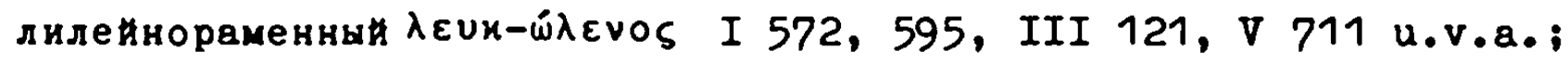

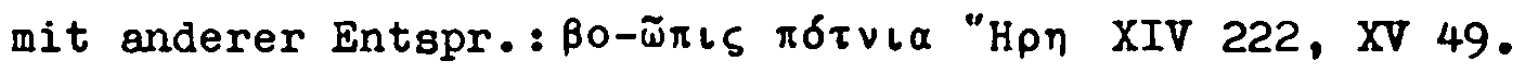

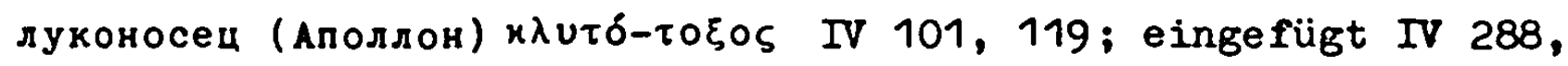
VII 81, XX 138.

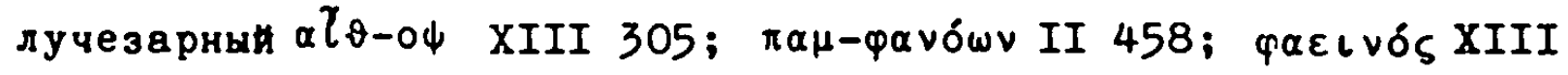

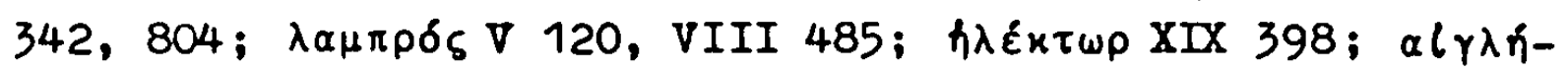

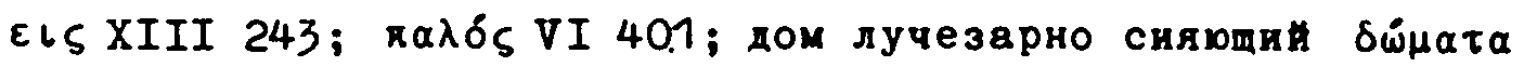

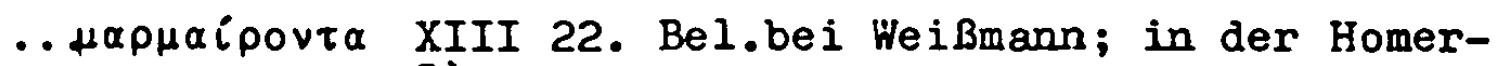
übers. Jekimovs ${ }^{3)}$; Nordstet; Heym M,R; Slov.Ak.Ross.1814.

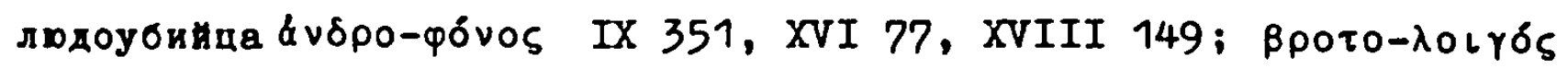
VIII 349.

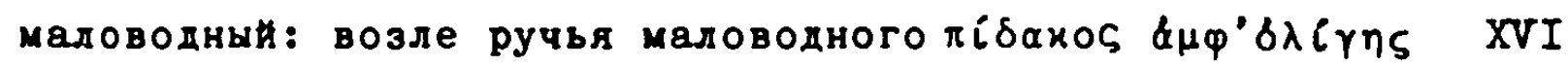

1.Nach Jegunov S.292, Anm.72, nicht von Gnedič geprägt; doch gibt Jegunov keine ältere Quglle für das Wort.

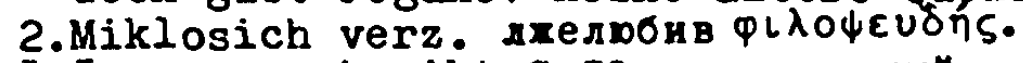

3.Jegunov schreibt S.59, лучезарны sei von Jekimor gepragt, die 1.Ausgabe des Wörterbuchs von Weißmann (1731) ist jedoch älter als die Iliasübers.von Jekimov (1776). 
825. Bel.bei Nordstet; Heym H,R; Slov.Ak.Ross.1814.

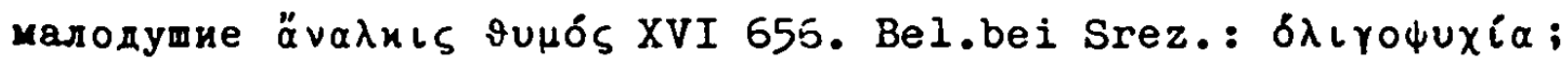

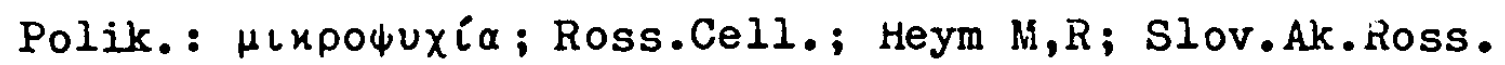
1814.

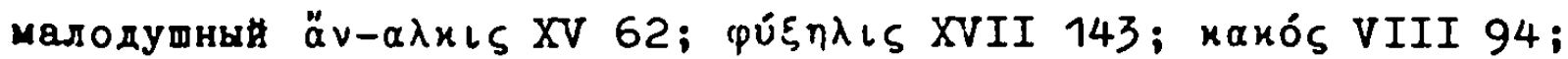

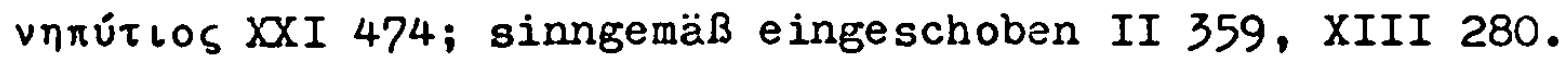
Bel.bei Srez.: $\delta \lambda \iota \gamma \delta ́ \psi \cup \chi \circ \varsigma$; Polik.: $\mu \iota x \rho \delta ́ \downarrow \cup \chi 0 \varsigma$; Ross.Cell.; Nordstet; Heym $M, R$; Slov.Ah.Ross.1814.

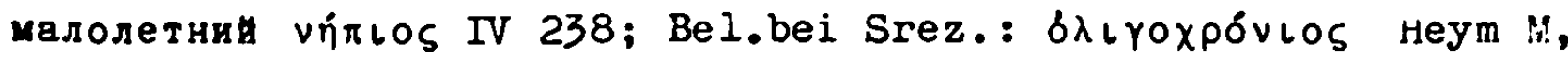
R; Slov.Ak.Ross.1814 mit harter indung; dagegen in der Volksdichtung bei Sobolevskij mit weicher ind., III Nr.566. малолюдныи: малолюдные лаи̃роц (В дни, как, уже малолюдные, в

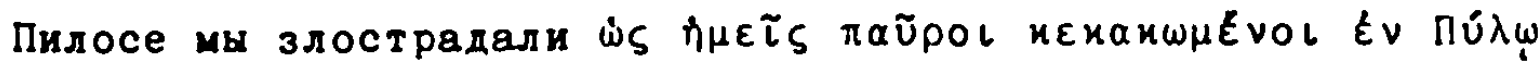
$\tilde{h}_{\mu \varepsilon v)}$ XI 688. Bel.bei Ross.Cell.; Heym H,R; Slov.Ak.Ross. 1814.

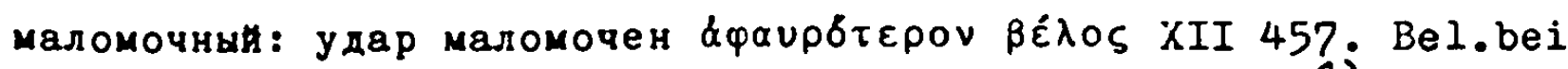

Nordstet; Heym ii,R; im Volkslied, Rybnikov I,444 ${ }^{1)}$.

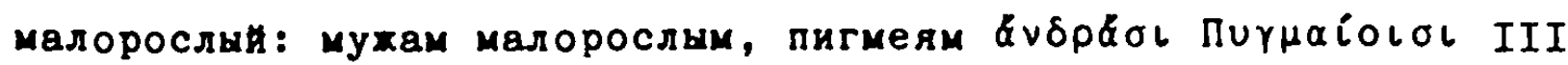

6. Bel.bei Nordstet; Heym M,R; Slov.Ak.Ross.1814.

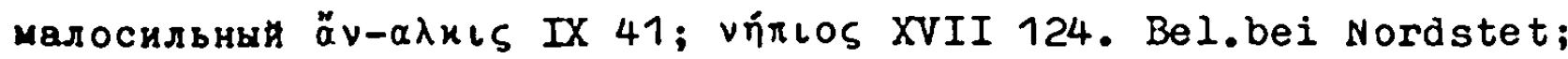
Heym M; Slov.Ak.Ross.1814. малосмысленнын

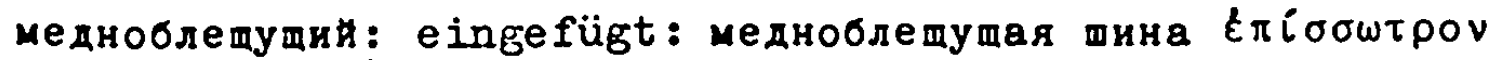
XXIII 5192).

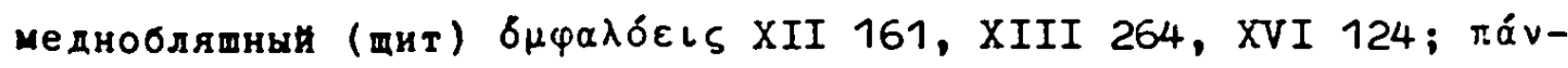

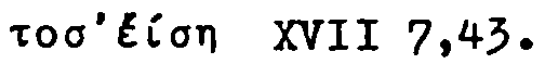

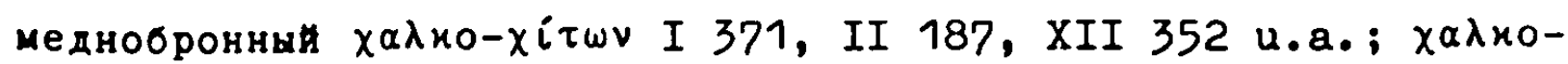

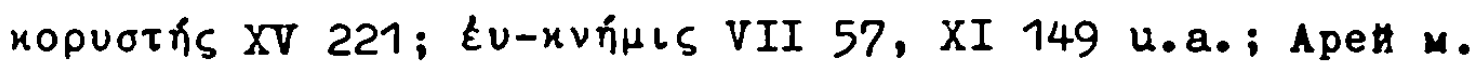

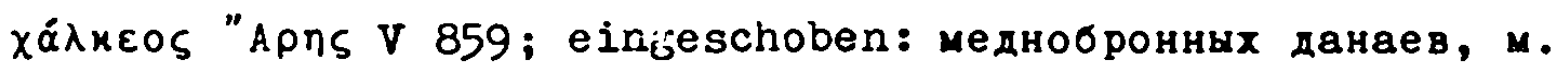

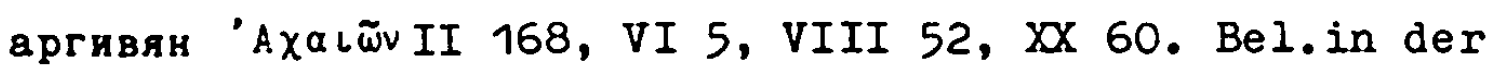
Homerübers. von Popov, vgl.Jegunov S.198.

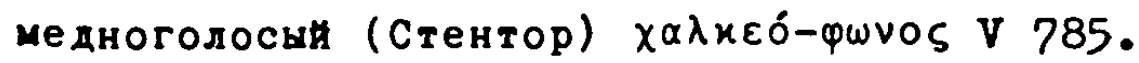

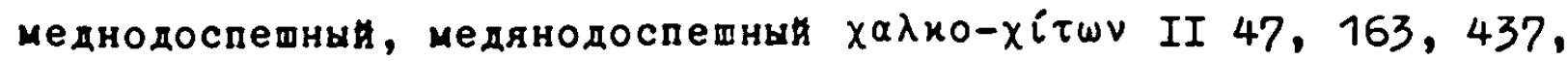
III 127, 131, 251 u.a.; $\chi \alpha \lambda$ xo-nopuotńs VI 398, V 699, XIII

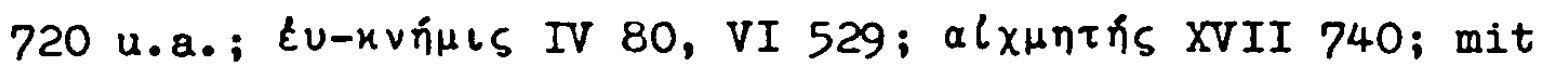

1.Vgl.Dickenmann S.247. - Srez.Suppl.verz. маломощьнын. 2. In der Homerübers.von Kondratovil ist belegt медноблистательнын, vgl.Jegunov 5.47 . 


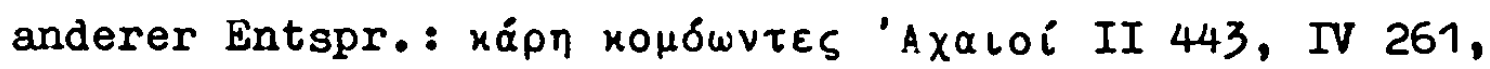
XIX 69; eingefügt II 760 .

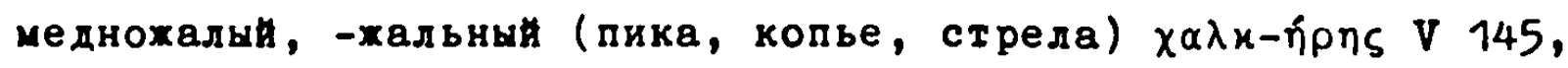

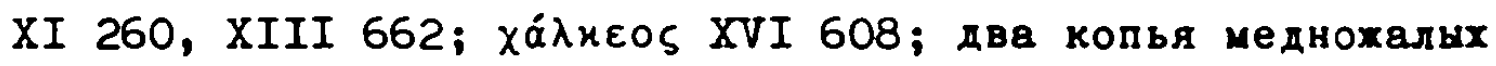

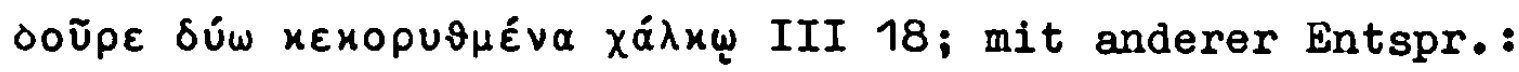
qaદıvós XIII 370; eingefügt XIV 373, XXI 165.

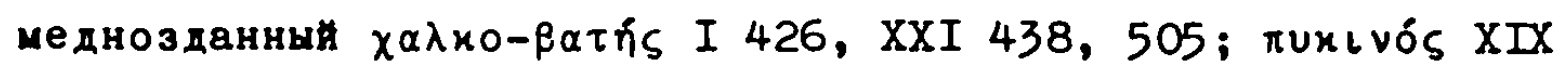

355.

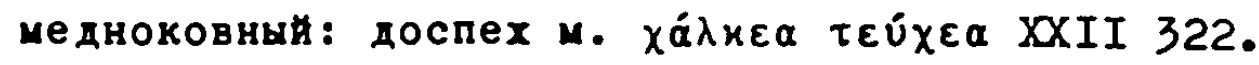

медноконечнын $\chi \alpha \lambda$ ко- $\gamma \lambda \dot{\omega} \chi\llcorner\nu$ XXII 225.

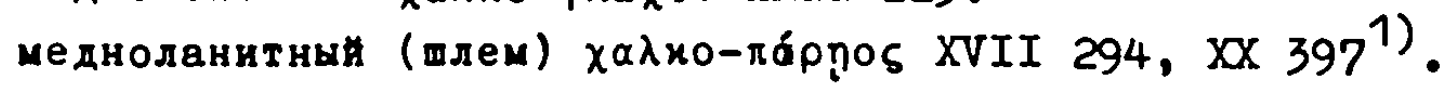

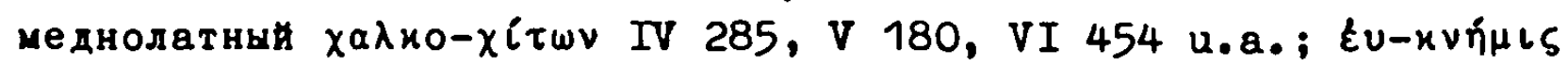

V 324, VII 430, XIII 51 u.a.; mit anderer Entspr.: nopu૭aíoגos XXII 471; eingefügt III 88, XI 706, XIII 367 u.a. медноногий (конь) халко́-почs VIII 41, XIII 23. медноогромны оhne genaue Entspr.: медноогромным мечом

$\mu \varepsilon \gamma \alpha \dot{\lambda} \omega \omega$ XX 459; ohne jede Entspr.: XVI 614.

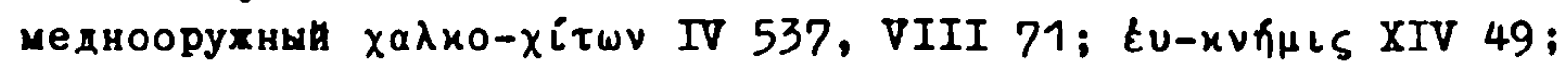

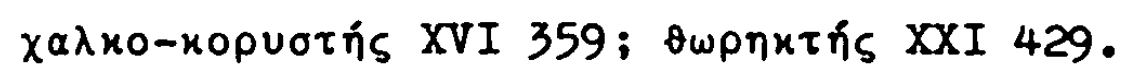

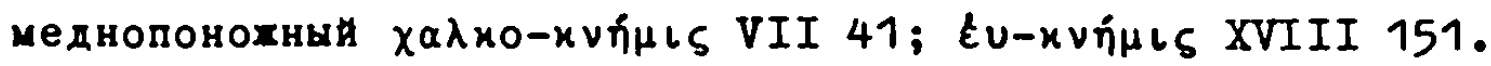
медностенны $\chi \alpha \lambda$ ко- $\beta \alpha \tau$ т́ XIV 173. меднотяхеди $\chi \alpha \lambda$ ио- $\beta \alpha \rho \hat{s}$ XI 96. меднощечнын (шелом) $\chi \alpha \lambda$ ио-па́рฤо๐ XII 183. медянодоспешнын s.u. меднодоспешнын.

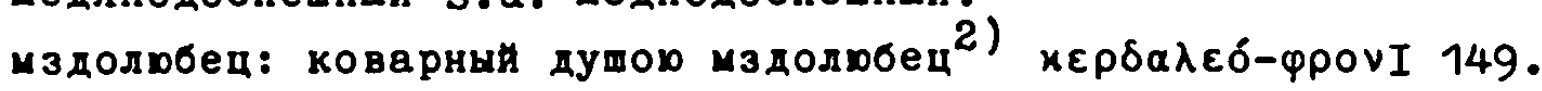

Bel.bei Nordstet; Heym $M, R$; Slov.Ak.Ross.1814.

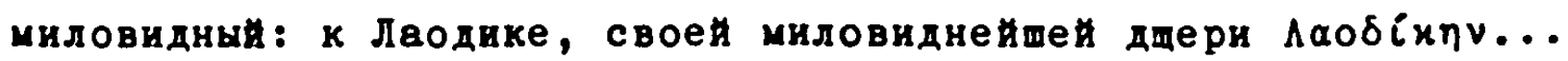

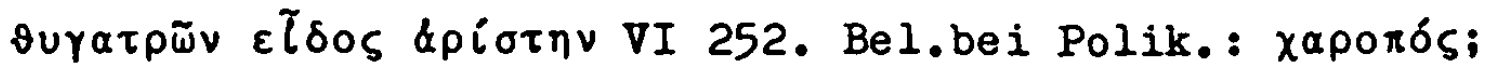
Ross.Cell.; Nordstet; Heym M,R; Slov.Ak.Ross.1814; im Volkslied, Sobolevskij IV Nr.204, -вндненькни III Nr.293.

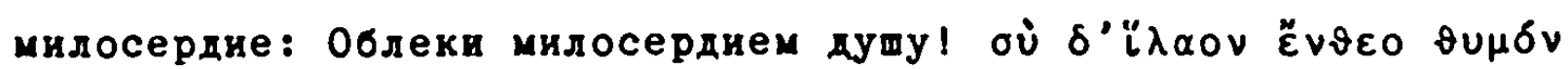

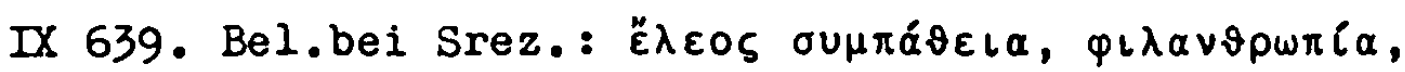

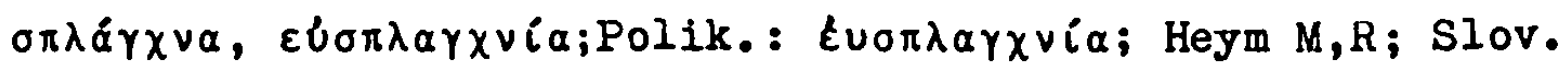
Ak. Ross. 1814 .

1. Auch von Martynov in seiner Homerübers.verwendet, vgl. Jegunov $\mathrm{S.325}$.

2.So in der Ausgabe von 1839. In der Ausgabe von 1829 steht мздонмед, vgl.Jegunov S.238. 


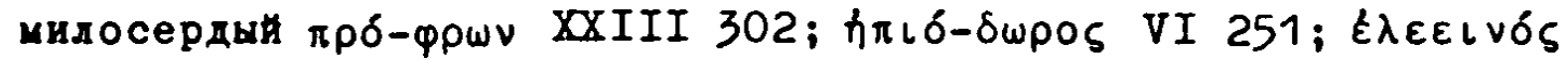
XXI 273; Дочь Эгиоха, усхышь! убыстри, милосердая, ноги!

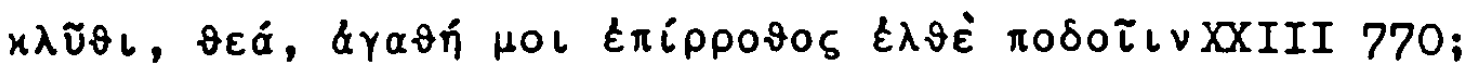

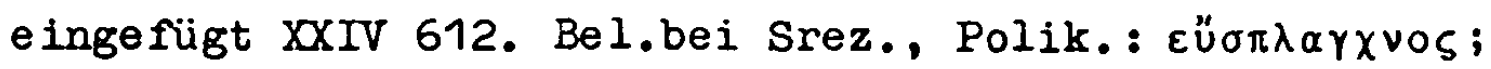
Nordstet (neben -cepднын), Heym M,R; Slov.Ak.Ross.1814.

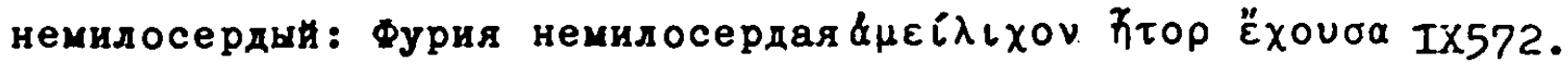
многобляшистын: sinngemӓB eingefügt: щит на плечо многобля-

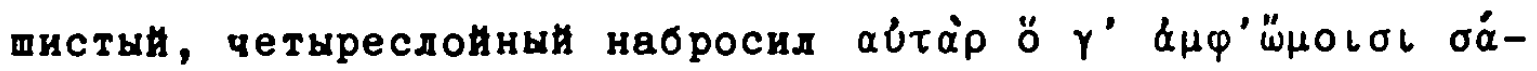

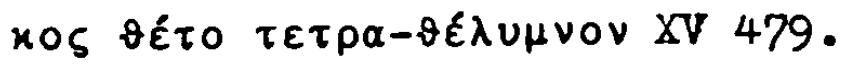

многобляшнын: sinngemäв eingefügt: шлем многобляшнын...креп-

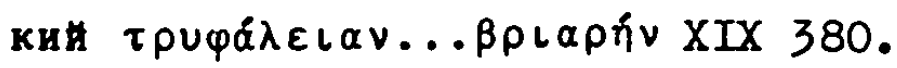

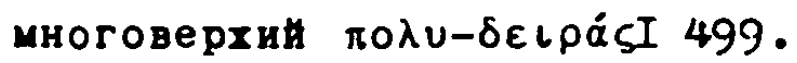

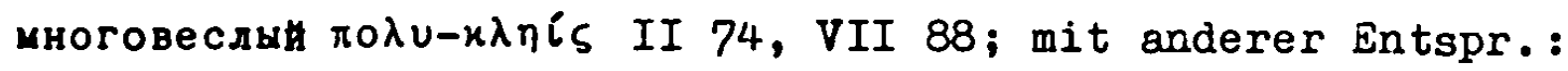

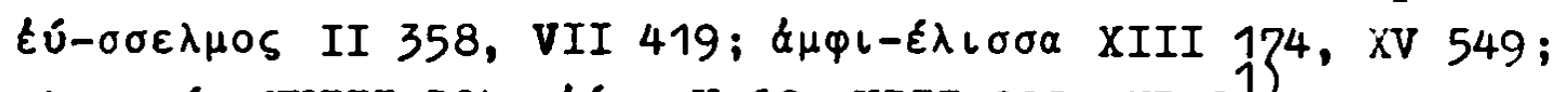

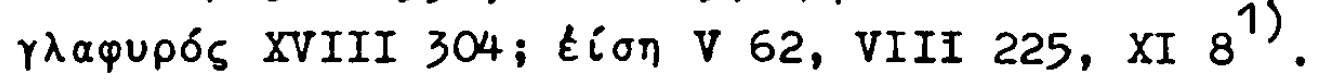
многовдастие поли-коцраvin II 204. многовдастны є anderer Bedeutung: на многовдастно ся обратившим Els xparias.

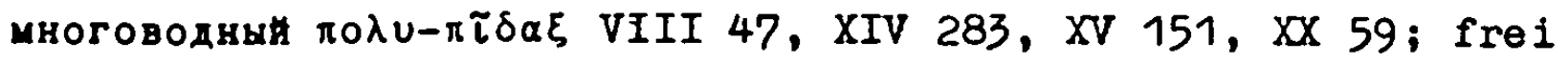
übers.: где искипает ручен многоводнын ӧэ'а̋ $\lambda\llcorner\varsigma$ \& $\alpha \beta \varepsilon \beta \rho \cup-$

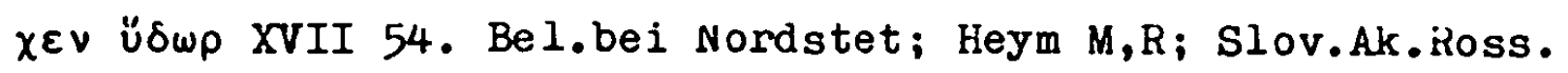
1814.

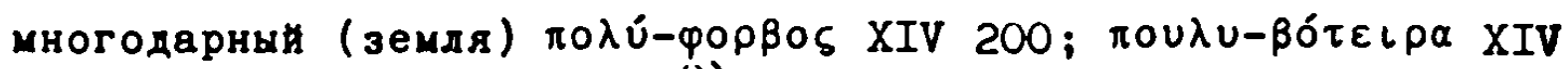
272. Bel.bei Miklosich ${ }^{2)}$.

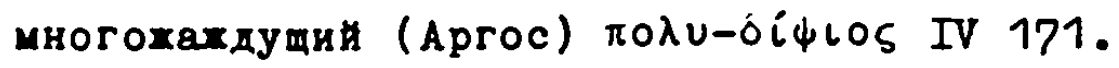

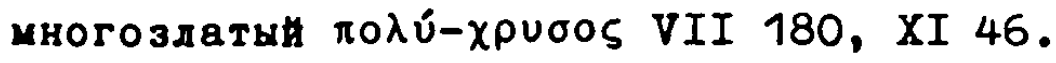

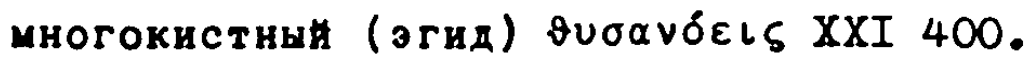

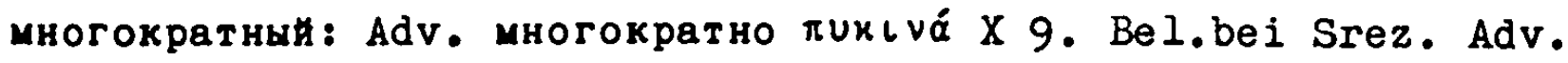

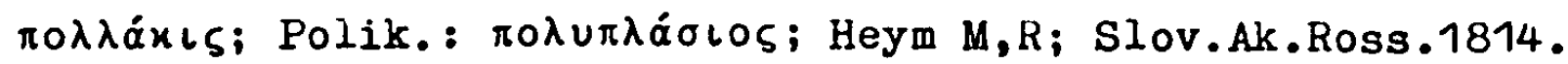

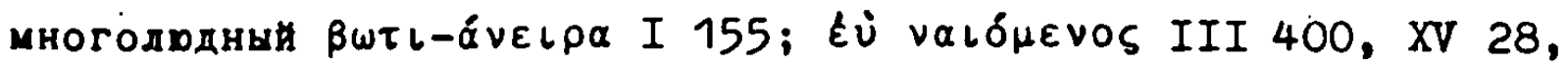

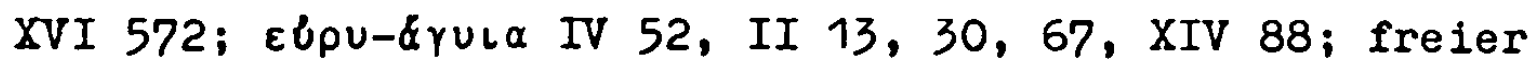

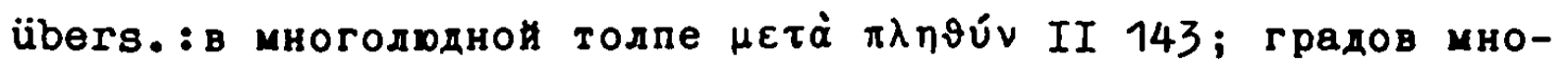

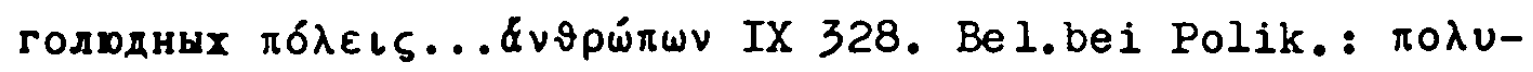

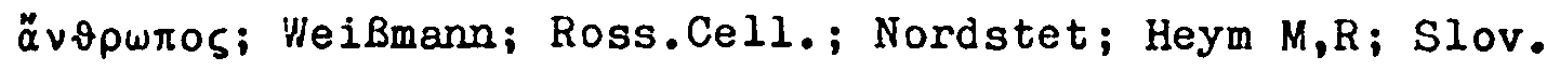

1.Kondratovid prägt in seiner Homerübers. многовеседьнын, vgl. Jegunov S.47.

2.Srez.verz. многодаровны = щедрын. 
Ak.Ross.1814.

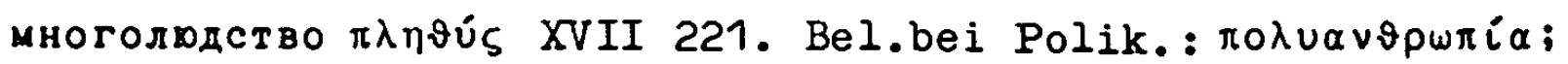
tross.Cell.; Heym M,R; Slov.Ak.Ross.1814.

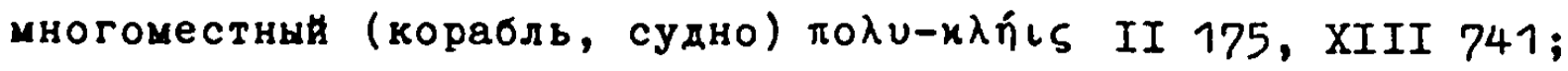
mit anderer Entspr.: noìos V 26, VII 389, VIII 98; हैú-

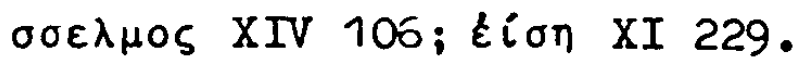

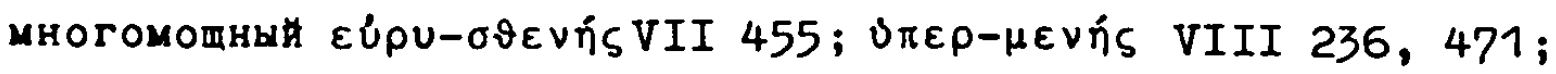

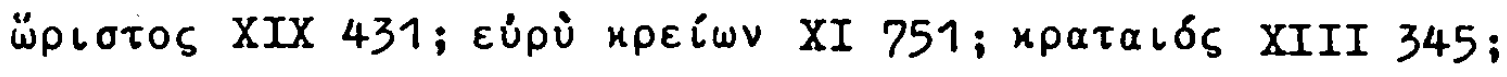
Kompar. многомотнее крєібошv XXI 190, 191; eingefügt V

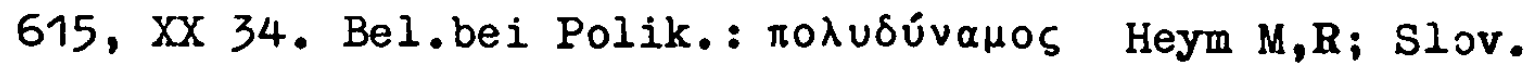
Ak.Ross.1814.

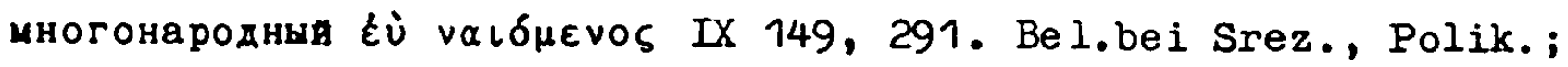
Weißmann; Heym R; Slov.Ak.Ross.1814.

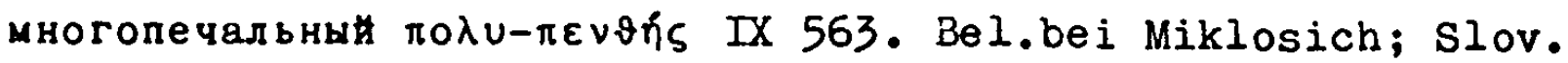
Ak.Ross.1814; Sokolov.

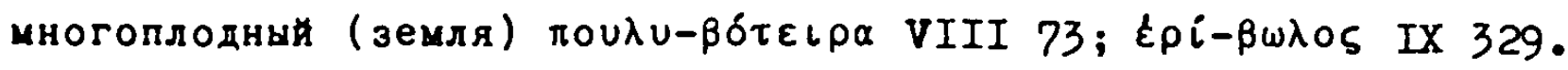

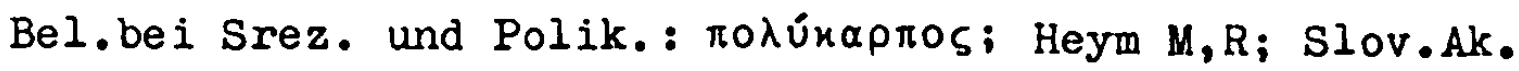
Ross.1814.

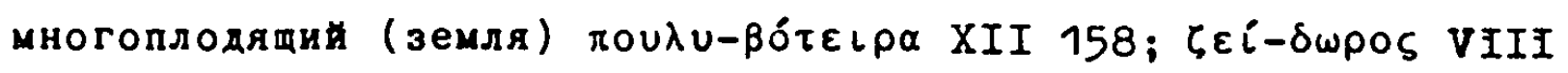
486.

многопочтенныи: mit anderer Entspr.: именем...матери много-

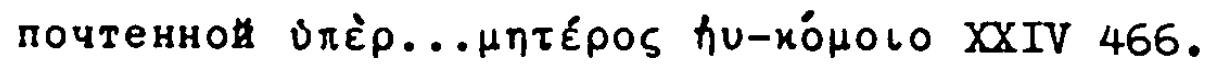

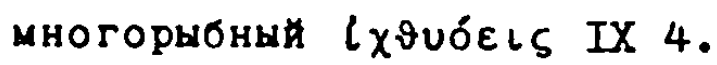
многославныи: Зевс многославный, велики $Z \varepsilon \tilde{~ и и ́ \varepsilon\llcorner б \tau \varepsilon \mu \varepsilon ́ ү \iota б \tau \varepsilon ~}$

III 298. Bel.bei Heym M,R; Slov.Ak.Ross.1814.

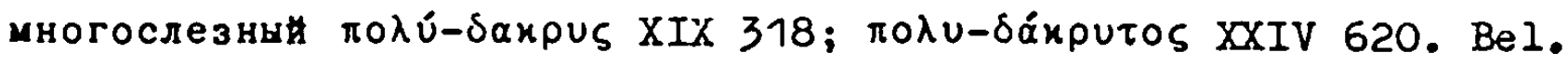
bei Miklosich = lacrimosus; Heym $\mathrm{M}, \mathrm{R}=$ von vielen Thränen begleitet, sehr beweint.

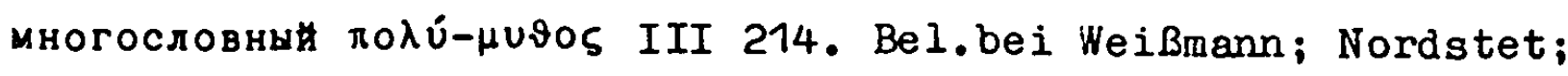

Heym $M, R$; Slov.Ak.Ross.1814.

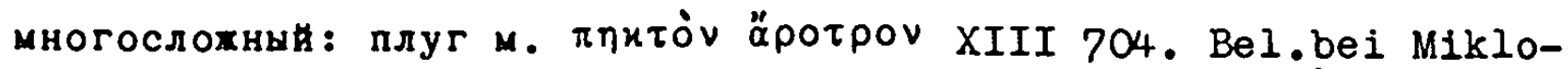

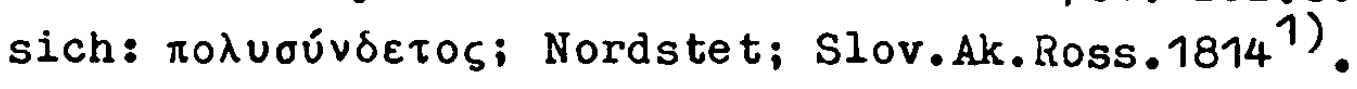
многоснехнын (Olymp) \&үá-vvıфоS I 419. Bel.bei Miklosich:

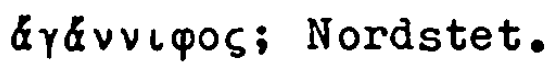

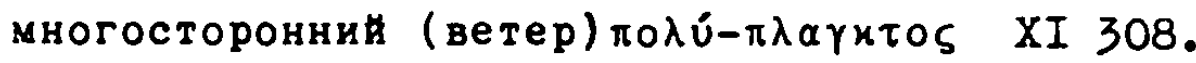

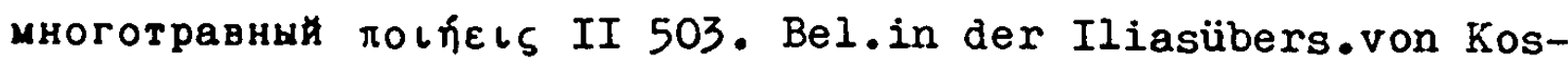
trov, vgl.Jegunov S.96.

1.Heym M,R gibt das Wort in der Bedeutung "vielsilbig". 


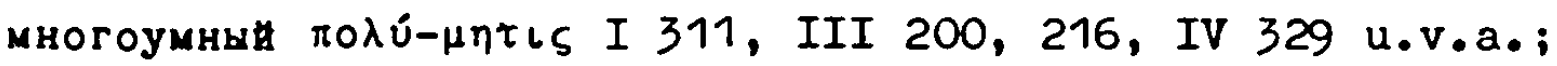

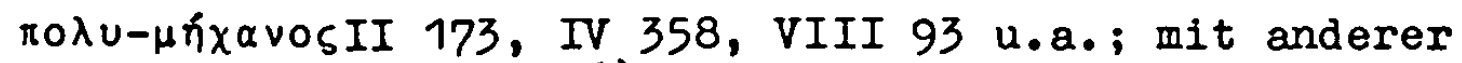
intspr.: o โos XIX $310^{1)}$.

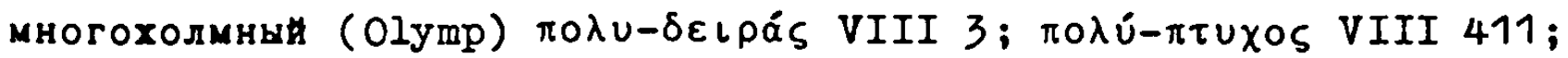

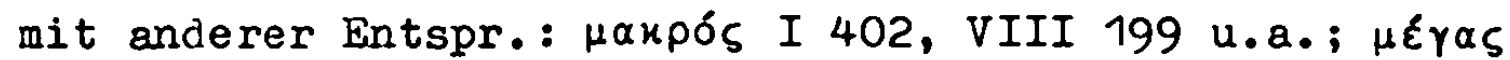
I 530. Bel.in der Homerübers.von Popov ist многохольмнын, vgl.Jegunov S.197.

многоценнын: М.выкуп, многоценная мзда \&

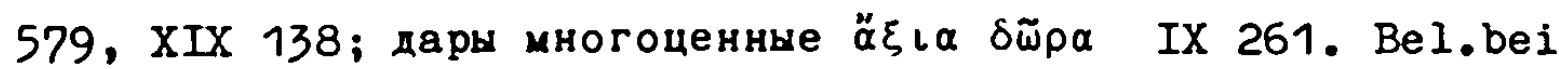

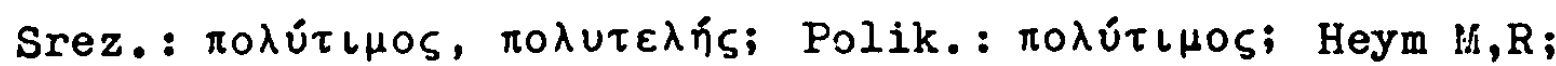
Slov. Ak.Ross.1814.

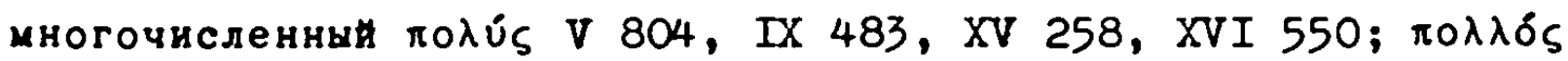

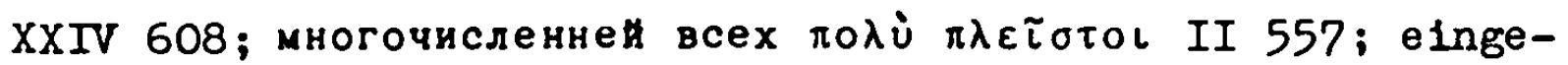

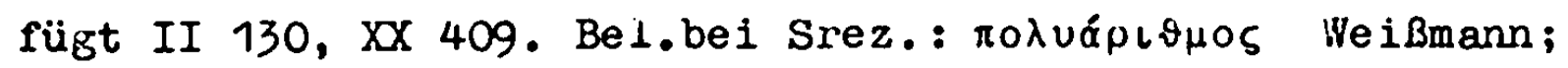

Nordstet; Heym $M, R$; Slov.Ak.Ross.1814. молневержец: frei übers.: бессилен и пламенны гром молневерж-

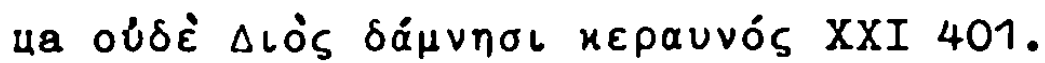

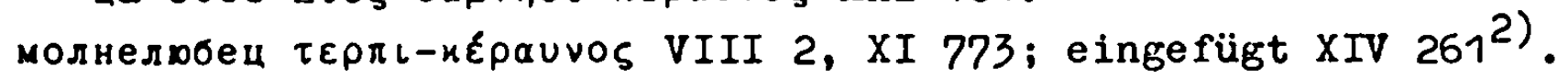

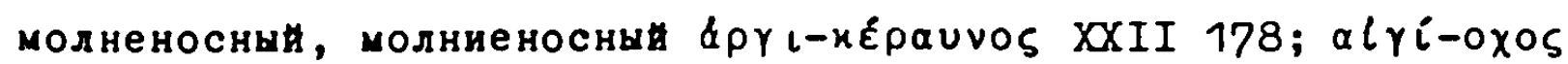

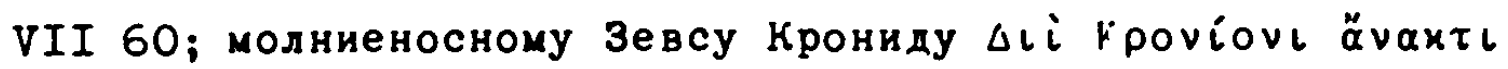
II 102; молненосного Зевса $\Delta \iota i$ латрі XVI 227. Молниеносны ist belegt bei Miklosich; in der Iliasübers.von Jekimov und Kostrov ${ }^{3)}$; bei Heym M,R; Slov.Ak.Ross.1814.

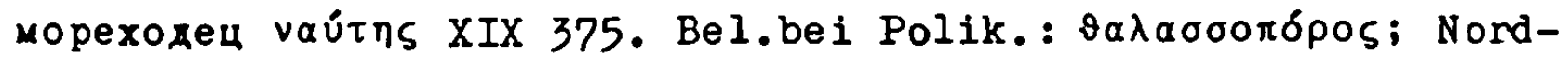
stet; Slov.Ak.Ross.1814.

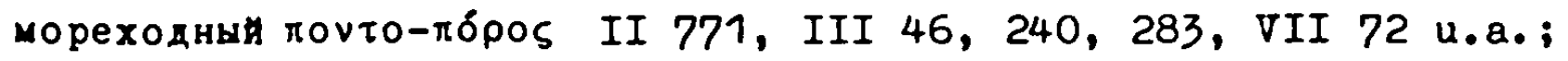

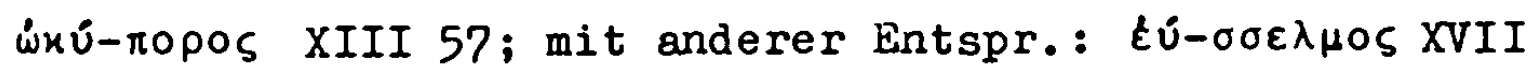

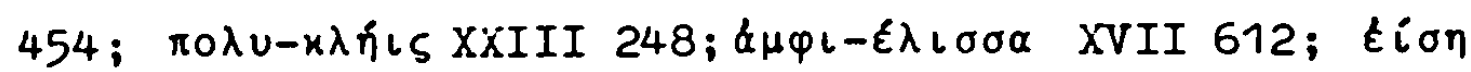

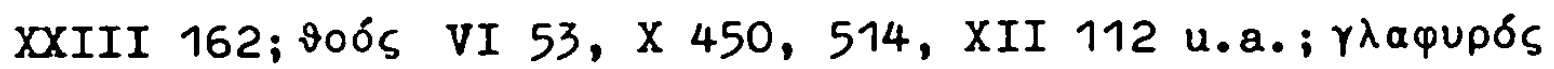

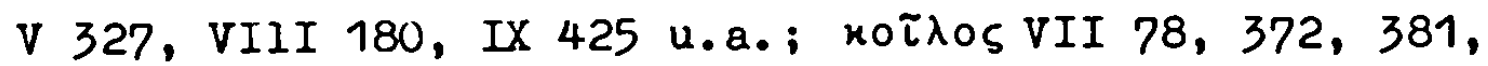

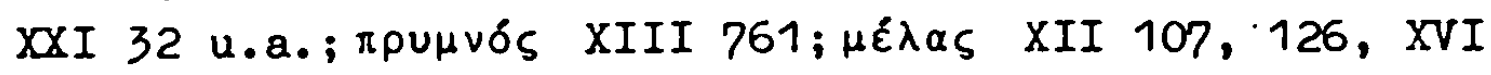

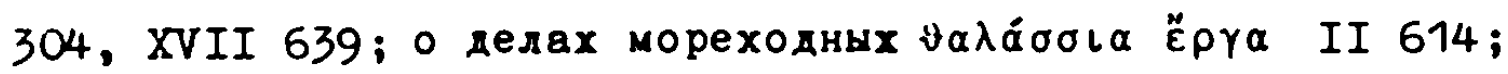

1. Miklosich verz. многоумие = prudentia und многоумьтель $=\pi 0 \lambda u ́ \pi \varepsilon l \rho \circ 5$, multa expertus. In der Volksdichtung findet sich многоразумнын, vgl.Hilferding S.544, Sobolevskij I Nr.3.

2. In seiner Homerübers.durch Alexandriner verwendet GnediC молнелюбивын, das auch bei Popov belegt ist, vgl.Jegunov S.153, 196. - Lomonosov übers. VIII 2 Зевес-громодеркитнль, vgl.Jegunov $\mathrm{S} .34$.

$3 . V g l . J e g u n o v$ S.59, 95. 
eingefügt I 476, VII 334, X 381 u.a. Bel.bei Trediakovskij ${ }^{1)}$; Nordstet; Slov.Ak.Ross.1814.

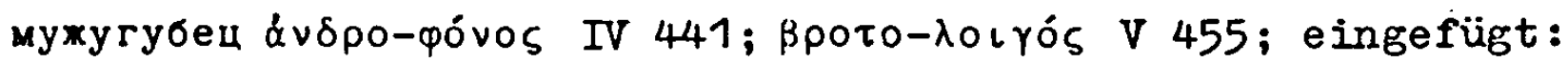

сыны мужегубца Арея Uїas "Apпоs IX 82.

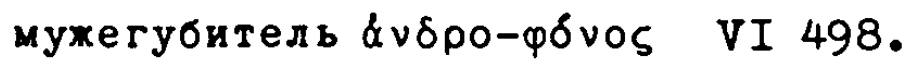

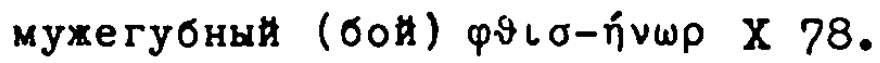
мухеобразнын (амазонка) \& $\nu \tau \iota-\alpha ́ v \varepsilon \iota p \alpha$ VI 1862). мужеубйственны $\alpha$ lvós с подвигов мухеубийственной брани

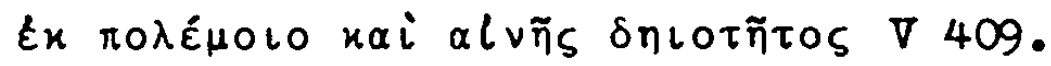

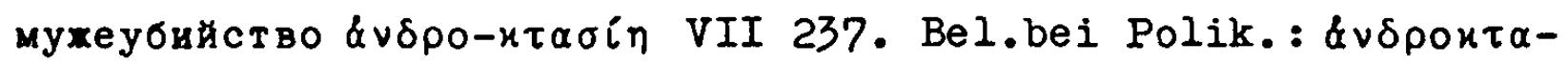

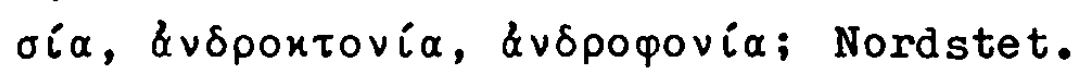

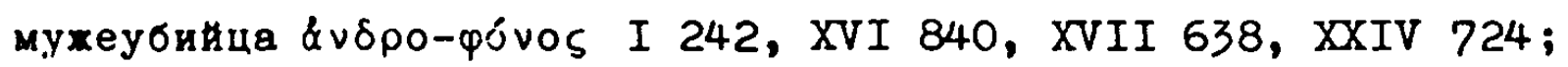
im Griech. anderer syntaktischer Aufbau: так обуздав ис-

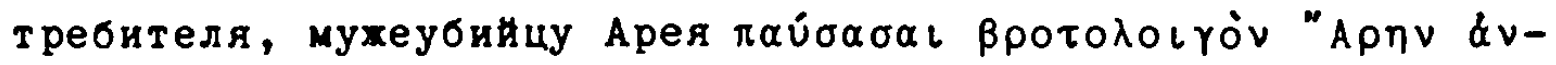

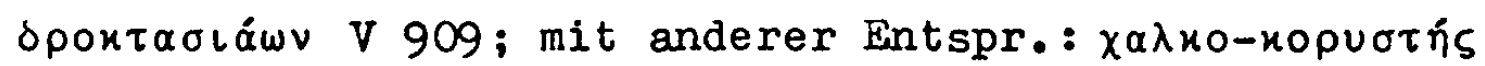

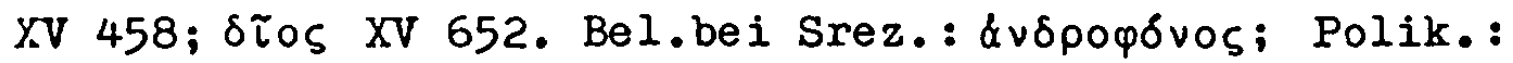

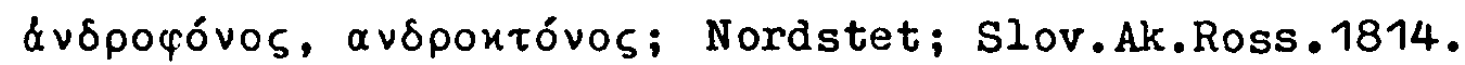

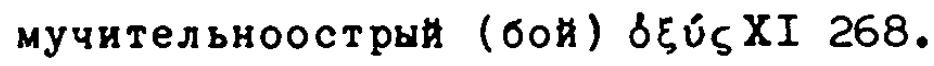

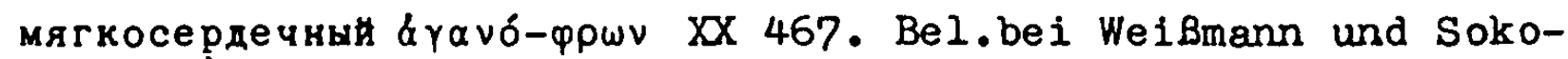
$10 v^{3)}$.

небеснодушисты (кудри) \&́ßро́оடоs XIV 177. неблагородны s.u. благороднын.

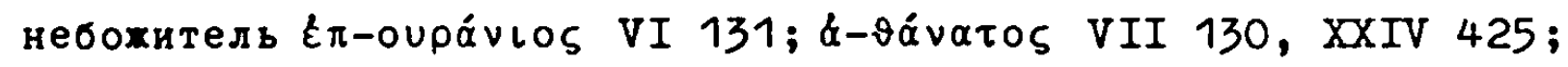

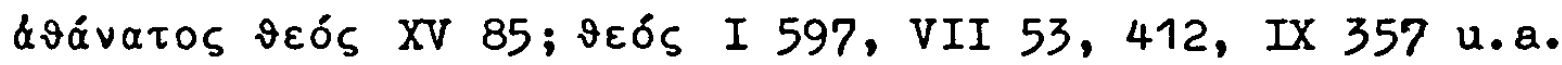

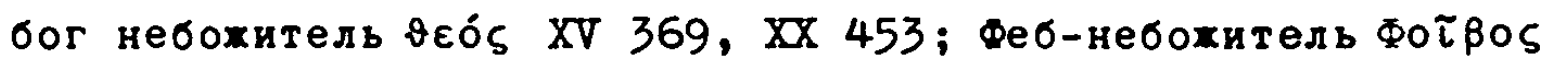
'A $\lambda \omega \nu$ XVI 804; небохительр bеzw. небохителям равнын \&

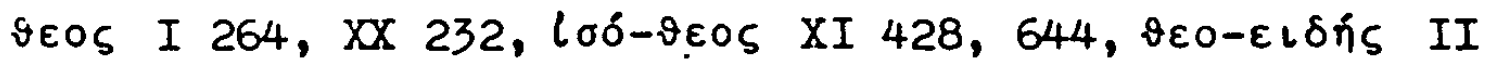

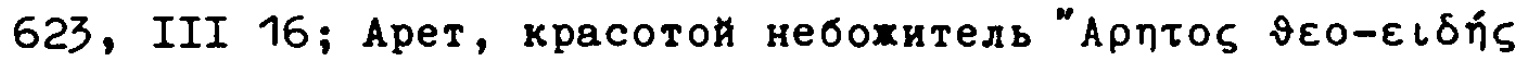
XVII 494; eingefügt I 607, XXI 514. Bel.bei Aleksejev, Церковнын словарь 1773; Heym M,R; Slov.Ak.Ross.1814.

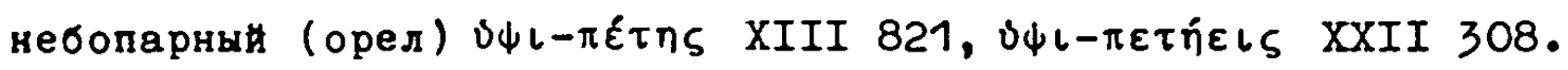

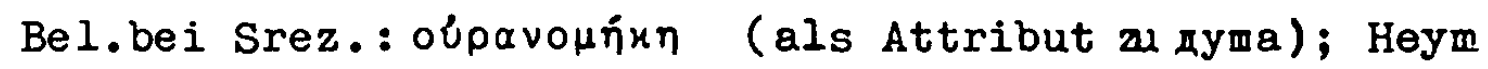

M,R; Slov.Ak.Ross.1814. немилосердын s.u. милосердын.

1.Vgl.Tschižewskij, ZfslPh Bd.17, S.144 ff; Hiittl-Worth S.120.

2.Slov.Ak.Ross.1957 führt für das Wort die Iliasübers. von Gnodit, ferner SLov.Ak.1847 als Beleg an.

3.Slov.Ak.Ross.1814 gibt мягкосердый. 


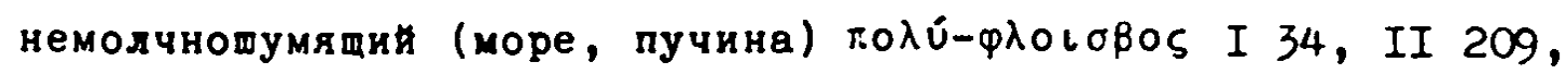
XIII 797.

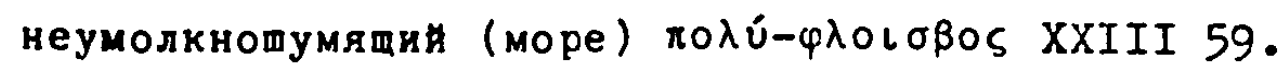
новобрачнын үйнаS XI 226; в новобрачном чертоге $\mu \cup \chi \tilde{\varphi} \vartheta \alpha \lambda \dot{\alpha}-$

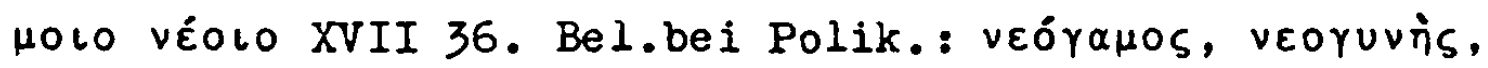
veóbuYos; Ross.Cell.; Heym M; Slov.Ak.Ross.1814; in der Volksdichtung, K.Danilov 97,397 .

новопришль $\vee \varepsilon-\eta \lambda \cup \varsigma ~ X 343$.

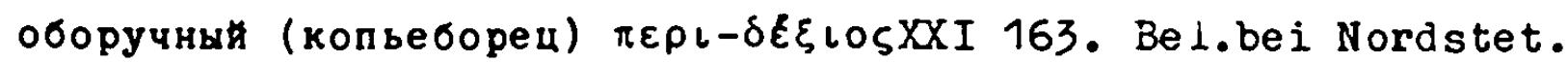

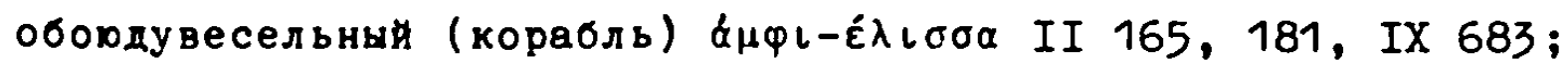

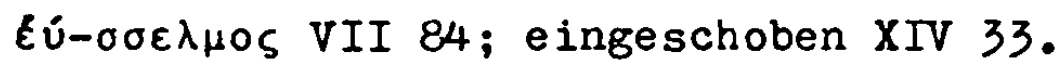

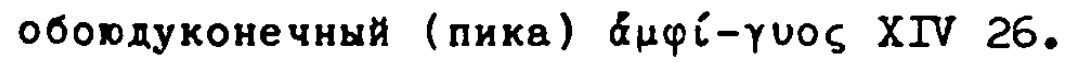

обтегубительнын (брань) бноі́ оS XVIII 242.

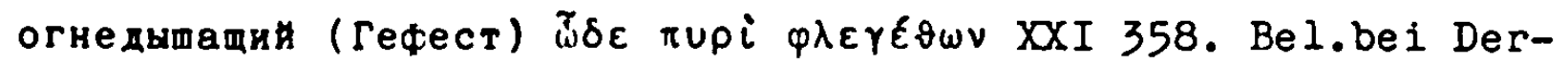

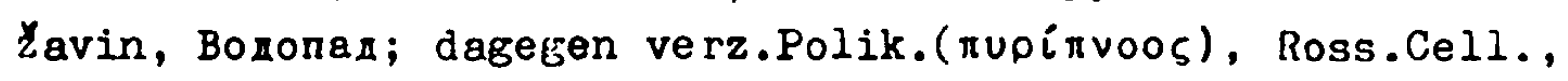

Nordstet, Heym M,R, Slov.Ak.Ross.1822, Sokolov siimtliche

огнедыпушй.

огромно-высокия: otne genaue kntspr.: от вертины горы огромно-

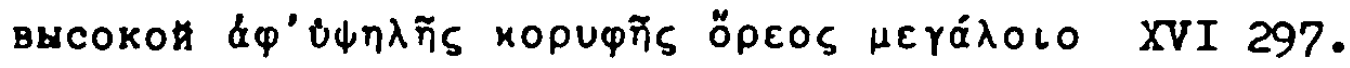

огромнокопеинын

одноборед тро́ноS VII 116 ${ }^{1)}$.

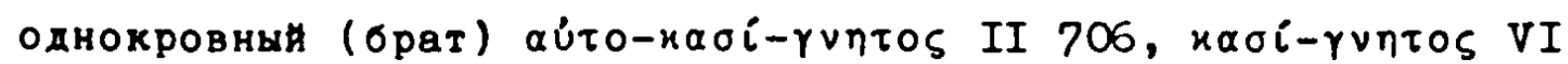

421. Bel.bei Nordstet; Slov.Ak.Ross.1822; im Volkslied,

Sobolevskij VI Nr.88 ${ }^{2}$ ).

однолетнй (крава) ท̆vıь VI 93, 274. Bel.bei Nordstet; Slov.Ak.

Ross. 1822 .

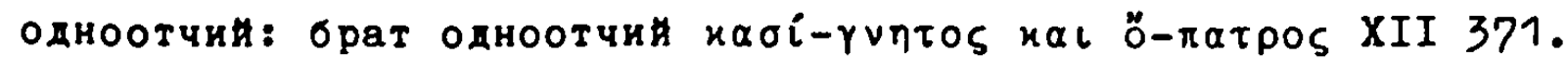
орухеносед блáwv XXIII 360. Bel.bei Nordstet; Heym M,R; Slov.

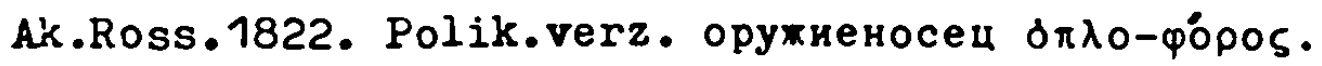

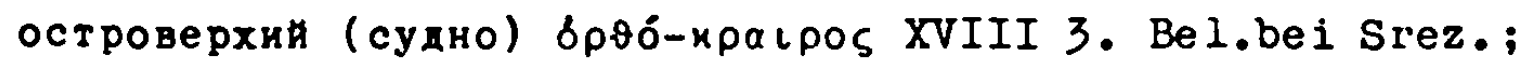

Slov.Ak.Ross.1822.

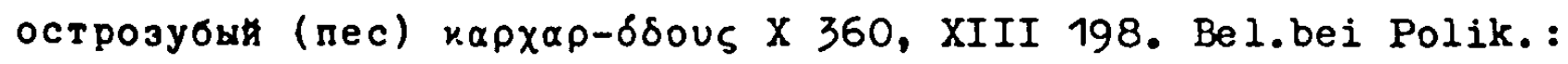

bรúbous; Ross.Cell.; Nordstet.

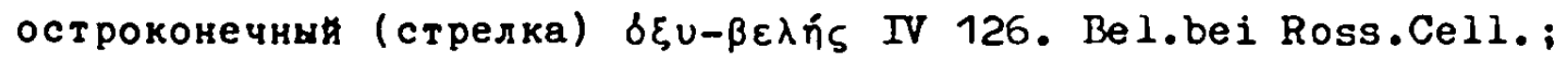

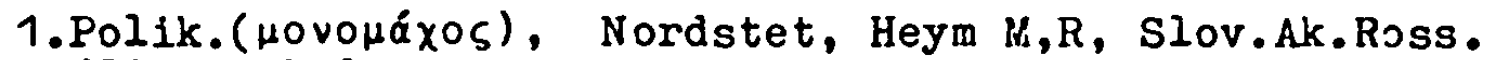
1809, Sokolov verz. единоборец.

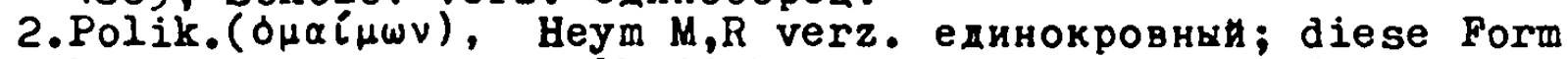
kommt auch in der Volksdichtung vor: Sobolevskij I Nr. 182, Hilferding $\mathrm{S} .1154$. 
Heym M, iR; Slov.Ak.Ross.1822.

осьмиспичный (колесо) бита́-xレпнољ 723.

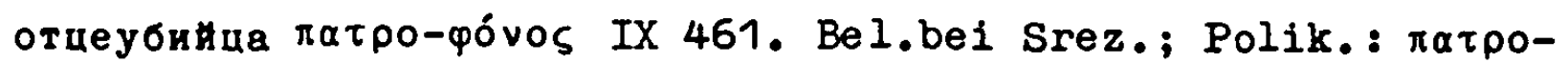

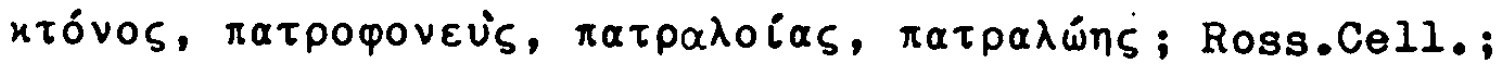

Heym M,R; Slov.Ak.Ross.1822.

очевиднын: sinngemäß übers. очевидно $h_{\text {то }}$ IV 13; и нак, оче-

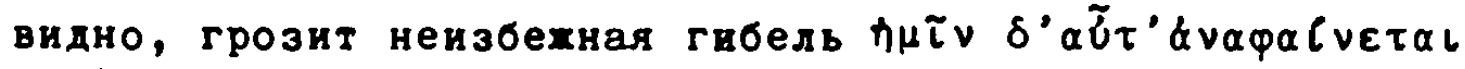

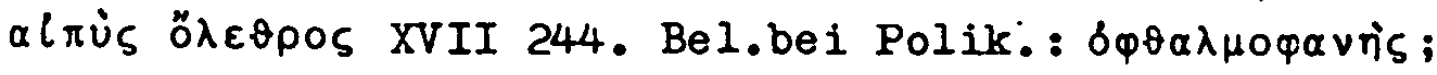

Ross.Cell.; Heym M,R; Slov.Ak.Ross.1822.

палиценосец иориขítᄁs VII 138.

палиценосныи корUVп்

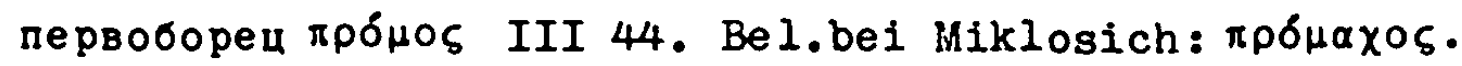

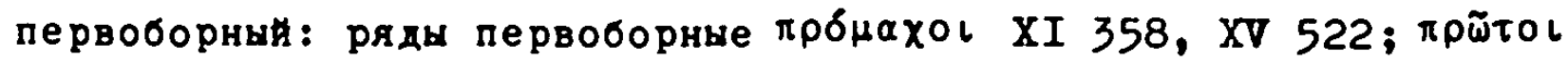

XIV 363, XX 338.

первороднни (агнец, овен) пршто-үоуоб IV 102, 120, XXIII 864.

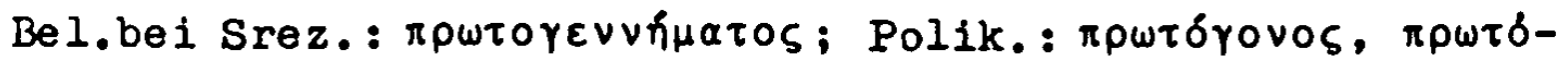

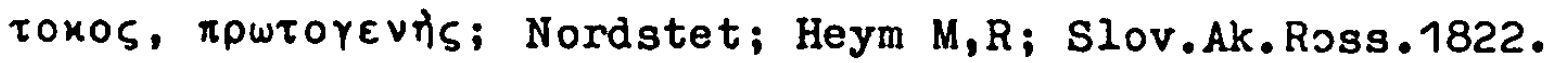

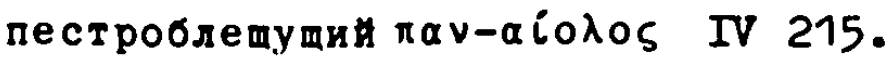

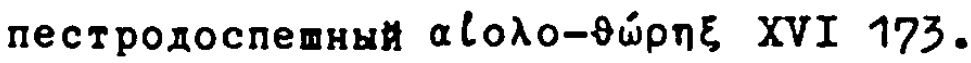

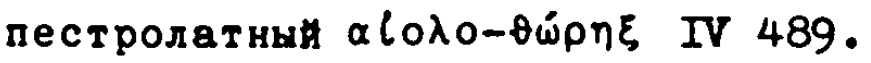

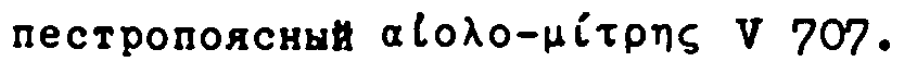

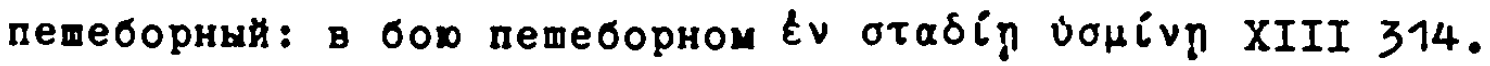

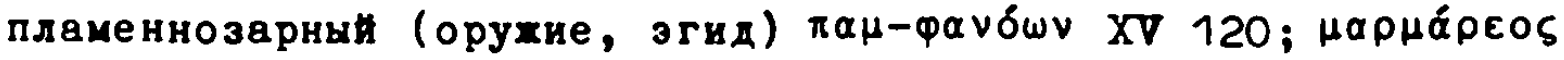

XVII 594.

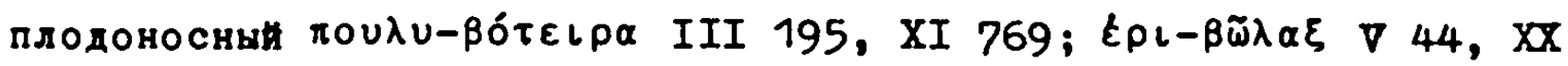

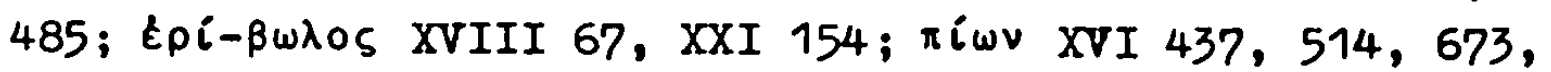

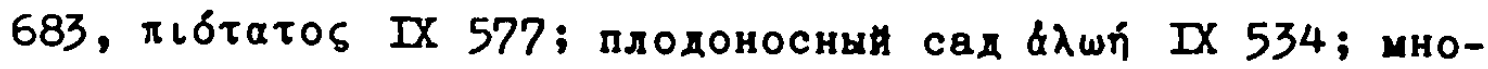

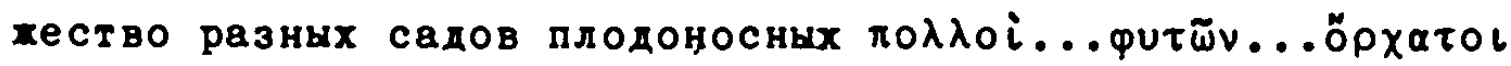
XIV 123; ohne Entspr.eingefügt XVI 455, XXIV 545. Bel.bei

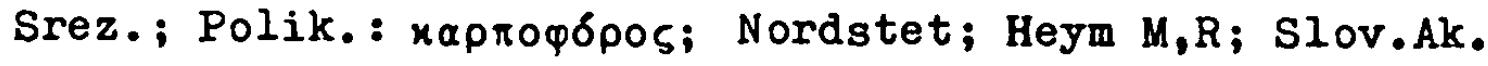
Ross.1822.

плодороднын (овен) Е̌v-орхоऽ XXIII 147. Bel.bei Nordstet; Heym $\mathrm{M}, \mathrm{R}$; Slov.AK.Ross.1822.

плотояднын: ohne genaue Entspr.: п самих распростер их в ко-

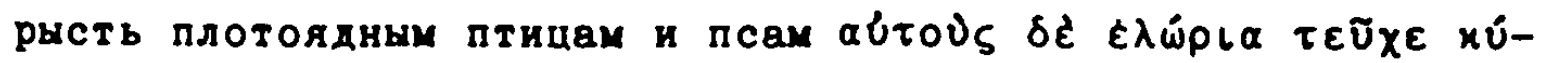

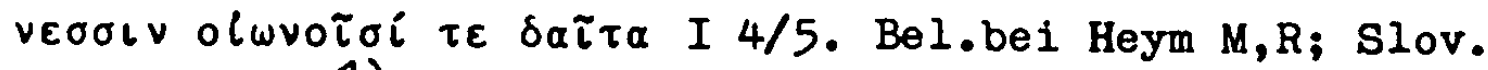
Ak.Ross.1822 ${ }^{1)}$.

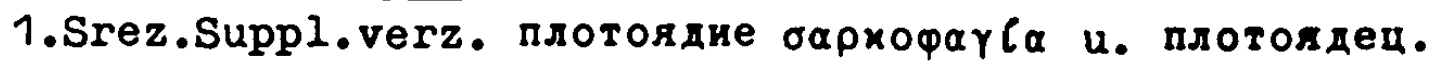


позднорохденны $64 i-\gamma о$ доS III 353. полногруды $\beta \alpha \vartheta \dot{-n о \lambda \pi о 5 ~ X V I I I ~ 122, ~} 399$. полнорослн (ветвь) $\varepsilon \rho \iota-\theta \eta \lambda n ́ s \times 467$.

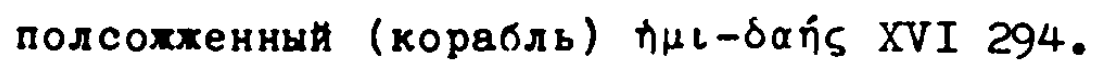

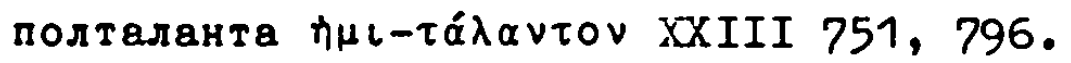

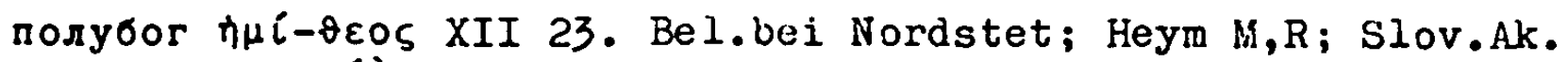
Ross.1822 ${ }^{1)}$. полуконченны

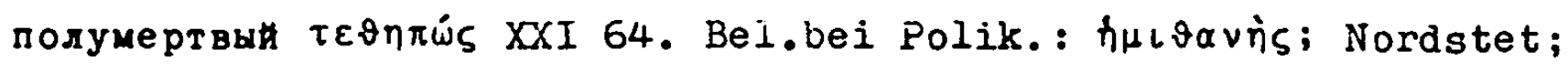

Heym $M, R$. праздноброднын (пес) dpүós I 50.

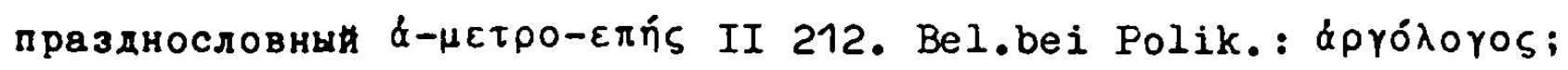

Nordstet; Heym li,k; Slov.Ak.Ross.1822.

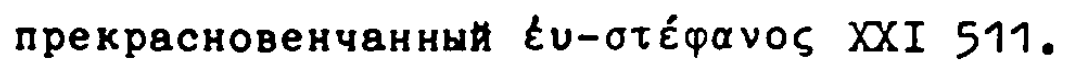

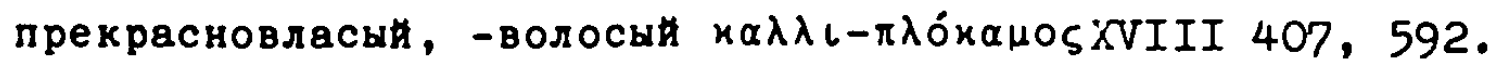
прекрасноланиты $x \alpha \lambda \lambda \iota-\pi \alpha ́ \rho \eta ⿻ 5$ I 346. прекрасносоставленнын $\varepsilon U-\varepsilon \rho \gamma \tilde{s}$ XIII 399.

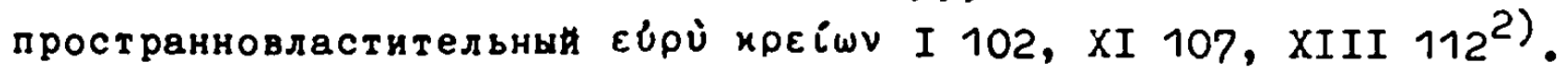
пространногремящи є

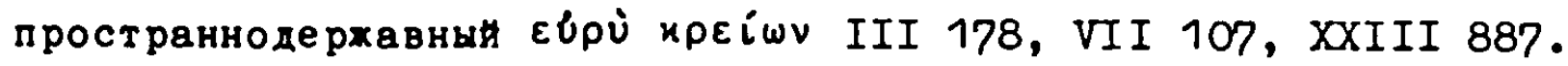

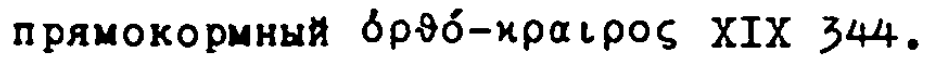

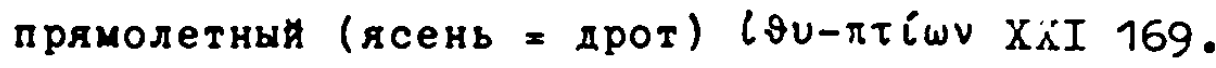

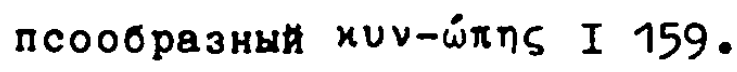

птицегаданье: и славного в птицегаданьи Эннома ка $і$ "Fvvоноv

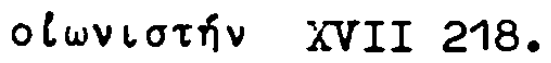

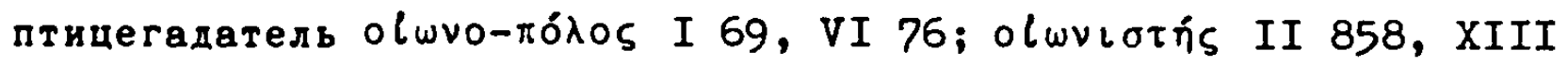
70. путеводец тонло́s XXIV 439, 4613).

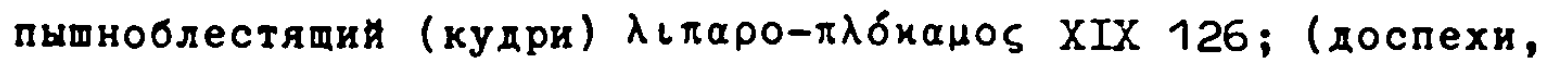

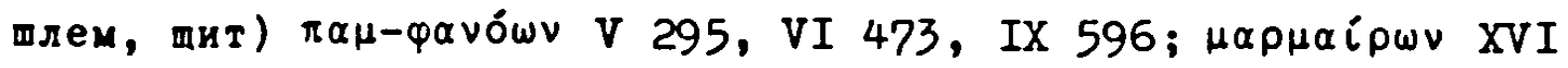
664; frei übers.: щит...медныи, кованы, пышноблестящия

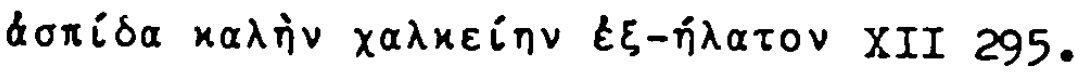

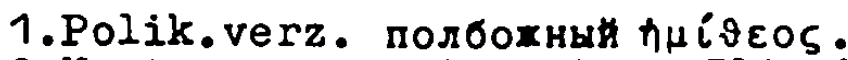

2.Kostrov prägt in seiner Iliasübers. пространновластвуя Атрид, Jekimov поют ранновладеющи Енносигеи, vgl.Jegunov S.95, 59.

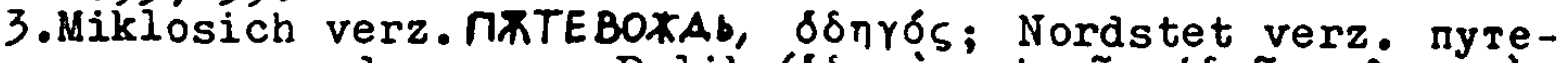

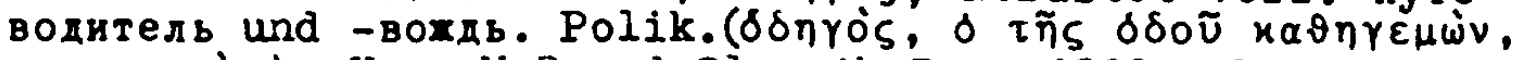

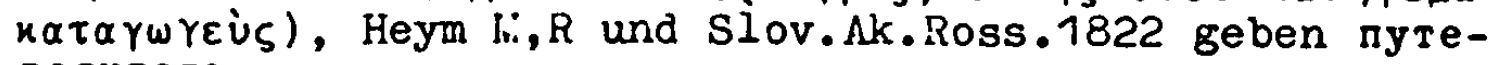
водитель. 


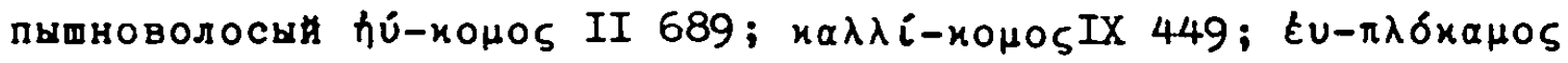
XXII 442, 449. Bel.bei Del'vig.

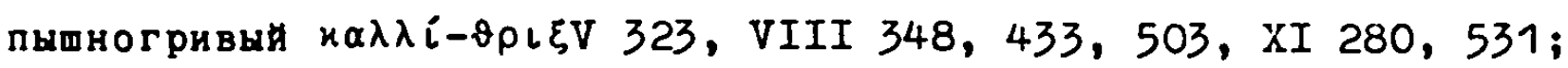

$\varepsilon \dot{u}-\vartheta \rho \iota \xi$ XXIII 301, 351; einge fügt XIX 244.

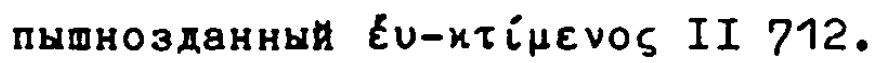

пышноодехны $\varepsilon \dot{U}-\pi \varepsilon \pi \lambda$ оS VI $372,378$.

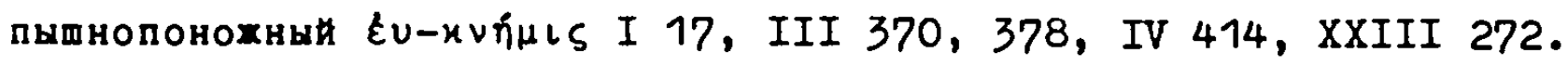
пьшноризы $\varepsilon \dot{-}-\zeta \omega$ Оо VI 467.

пьшносиярщи (медь) ขш̃роф XIV 383.

пьшноструистыи: ohne Entspr.: Мехду брегов Симоиса и пишно-

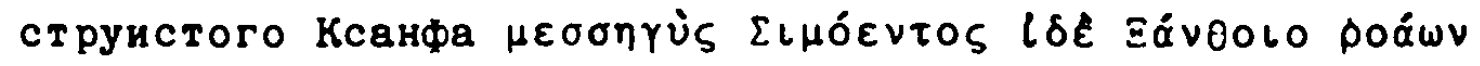

VI 4.

пышноструннын $\ell \dot{-}-\rho$ роо VII 329.

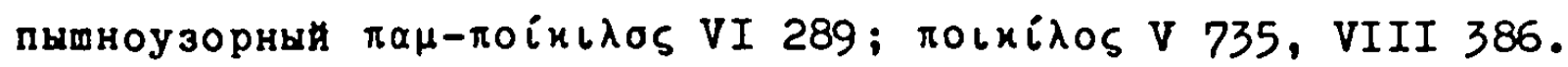
пятизубед $\pi \varepsilon \mu \pi-\dot{\omega} \beta о \lambda$ оV I 463.

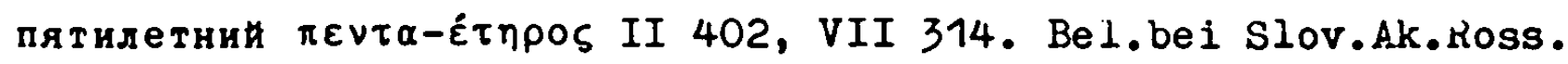
1822; Heym S; Polik. ( $\pi \varepsilon v \tau \alpha \varepsilon ์ \tau \eta S, \pi \varepsilon v \tau \eta \varepsilon ์ \tau \varepsilon \rho \circ \varsigma)$. Nordstet verz.das Adjektiv mit harter Endung.

равновесның (брань)loos XII 436. Bel.bei Nordstet; Heym $U, R$; Slov.Ak.Ross.1822.

равнодушнин: im Griech.verbal: не бвл ко мне равнодушен об

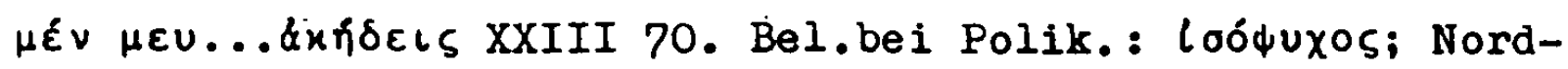
stet; Heym M,R; Slov.Ak.Ross.1322.

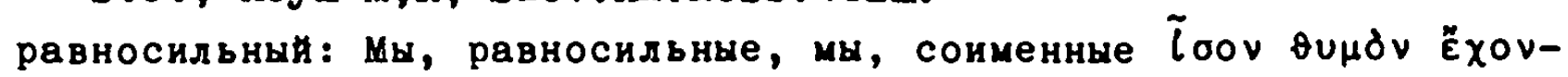

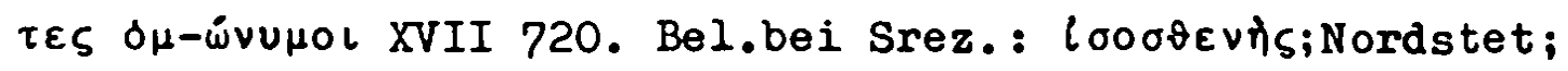
Heym M; Slov.Ak.Ross.1822.

разновиднын: im Griech.verbal:извил хоровод разновидның хоро̀v

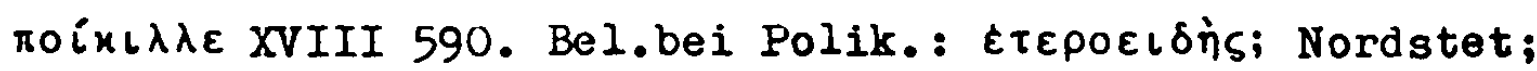
Heym M; Slov.Ak.Ross.1822 (unter разнороднын aufgeführt). разноземнын: ohne genaue Entspr.: Но различның язык разнозем-

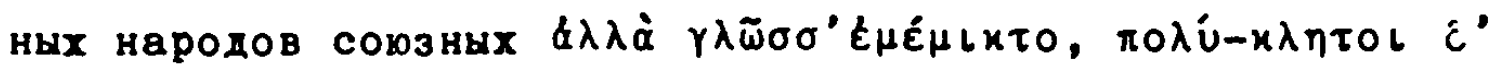
$\tilde{\varepsilon} \sigma \alpha \nu$ ã $\nu \delta \rho \varepsilon S$ TV 438.

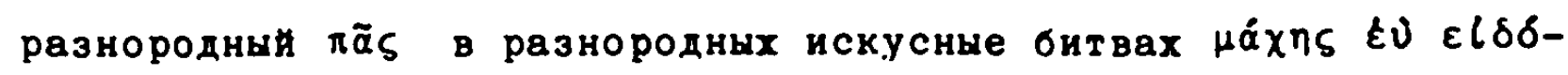

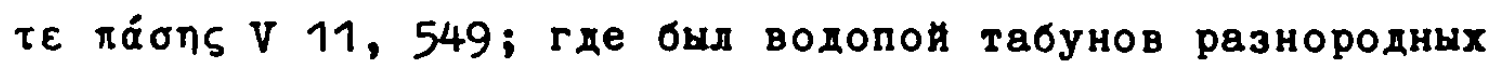

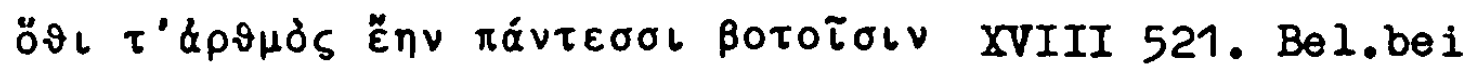
Ross.Cell.; Nordstet; Heym M,R; Slov.Ak.Ross.1822. разноцветнын $\pi \alpha v-\alpha i \circ \lambda \circ 5$ X 77. Bel.bei Nordstet; Heym M,R; Slov.Ak.Ross.1822; in der Volksdichtung, K.Danilov 74, So- 
bolevskij IV Nr.13, 14 u.a.

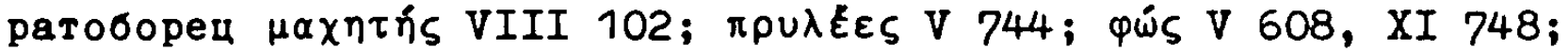

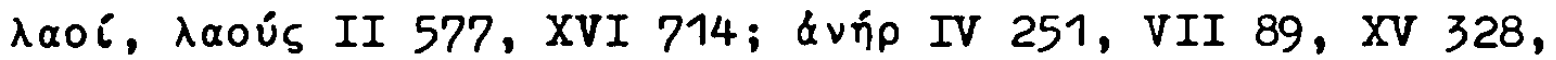

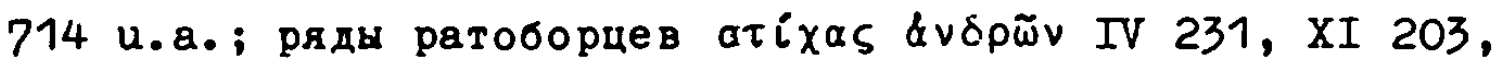

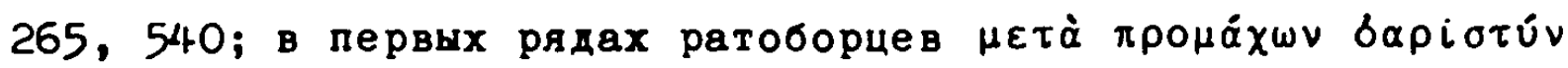

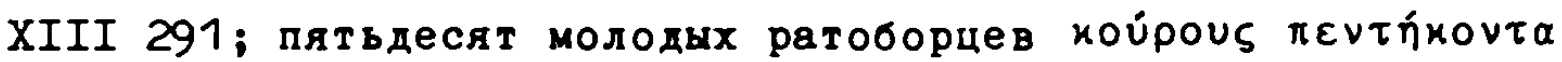
IV 392; ohne Entspr. eingefügt II 627, III 124, IV 81 u.a.

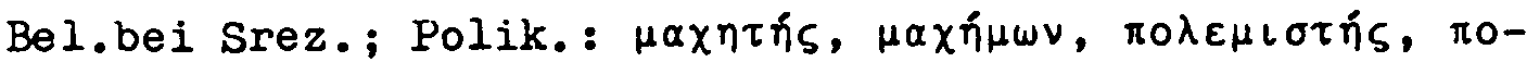

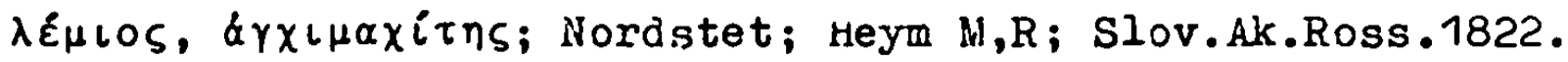
ратоборнын: meist frei übers.: по рядам ратоборным он ходит

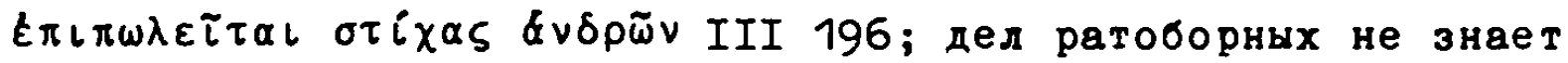

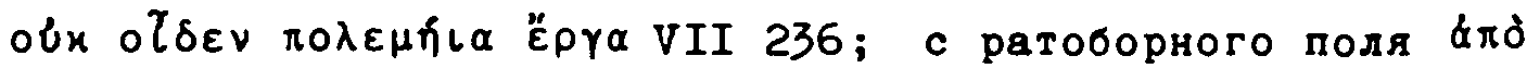

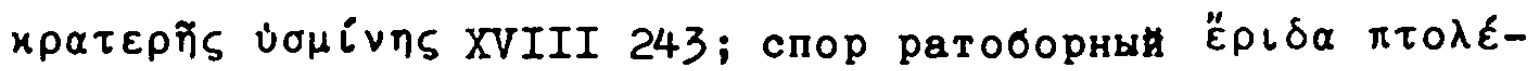

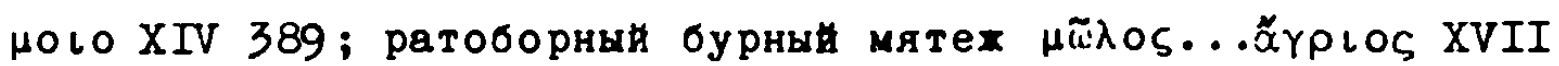
397. Bel.bei Heym M,R; Slov.Ak.Ross.1822.

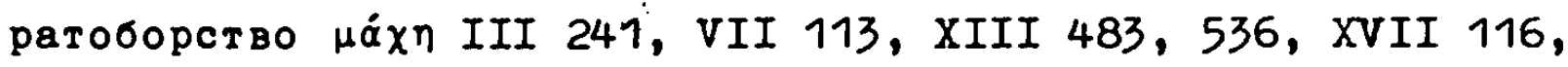

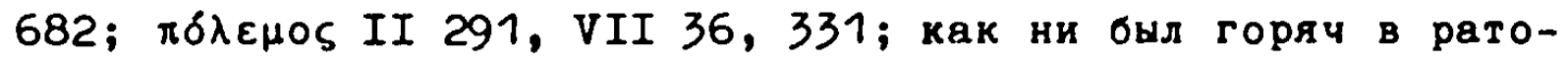

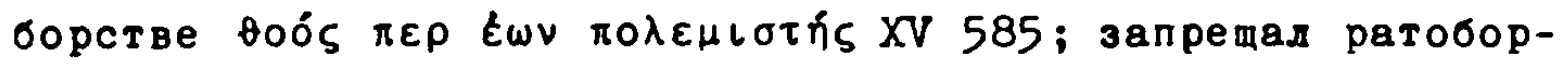

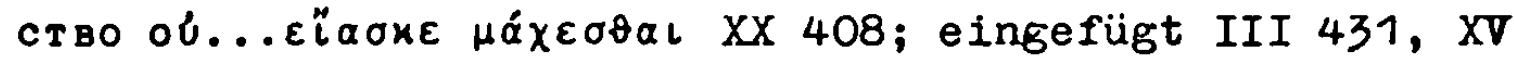
475; в ратоборстве искуснын eingeschoben nach Петеид Ме-

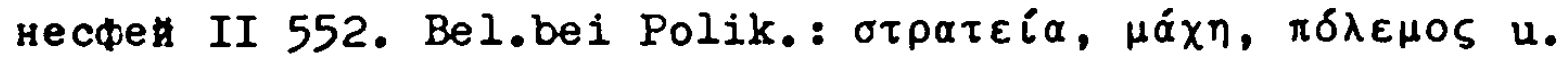
a.; Nordstet; Heym M,R; Slov.Ak.Ross. 1822.

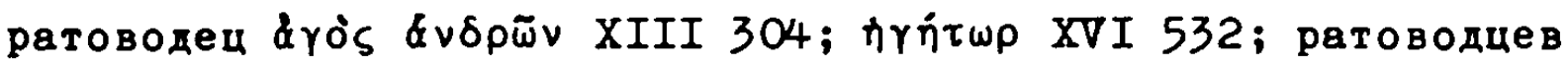

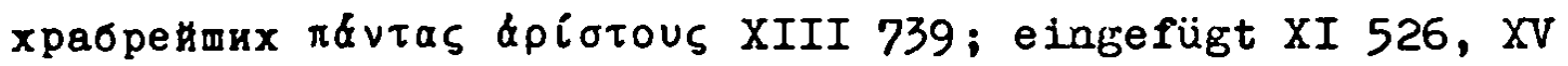
706, XVI 179, 311.

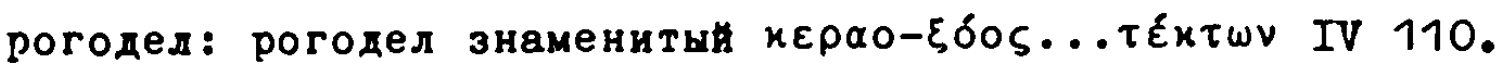
родоначальник: Родоначальник мон славны - Аксин тирокотеку-

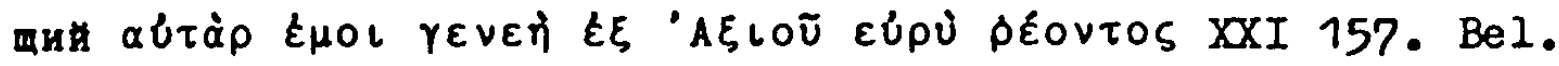
bei Srez.; Nordstet; Heym M,R; Slov.Ak.Ross.1822. родоначальница: Верно, Родоначальница ти кудреглавых народов

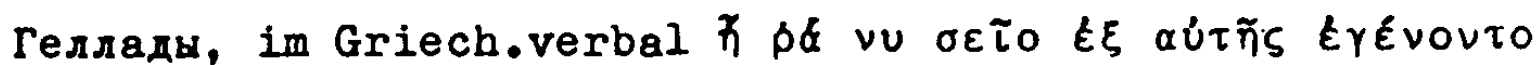

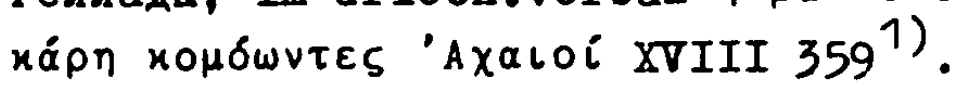

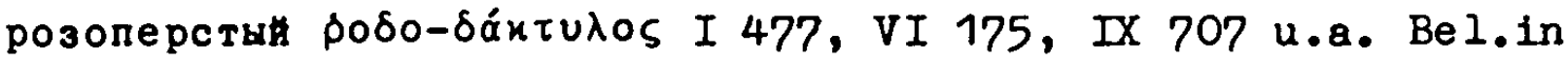
der Iliasübers.von KondratoviC, vgl.Jegunov $\mathrm{S.47}$.

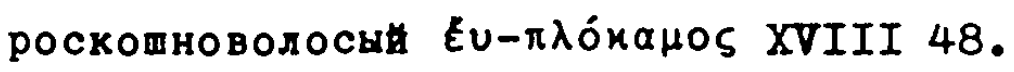

1.Slov.Ak.Nauk 1961 führt als Quellen G.Uspenskij, M.Gor'kij und USakov, Tolk.Slov.1939 an, also lauter Belege, die viel später liegen als Gnedið. 


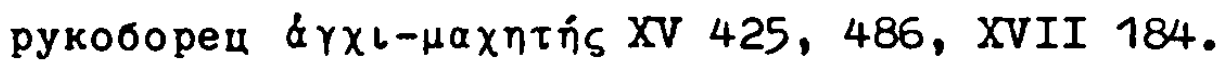

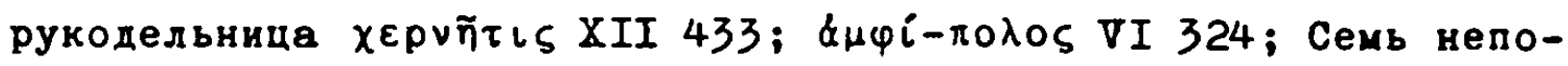

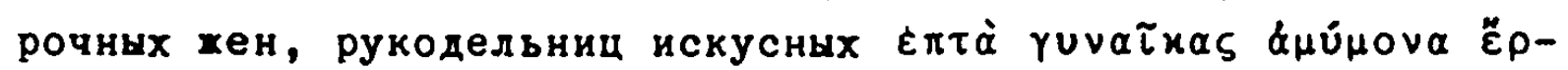
үa lovĩs IX 128, 270; Мздон побежденному он рукодельницу

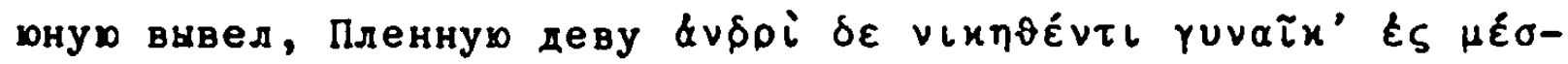

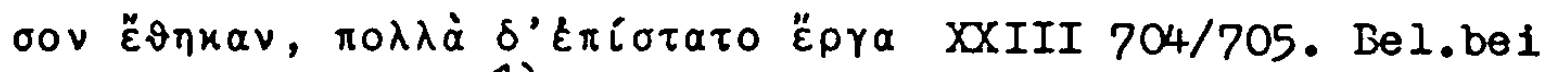
Nordstet; Heym $M, R^{1}$ ).

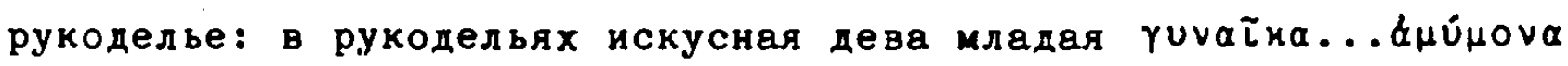

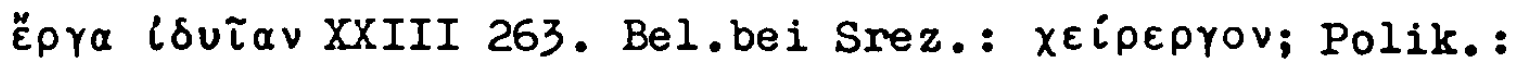

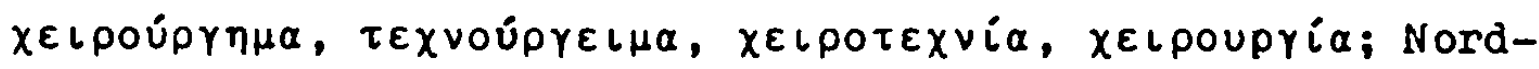
stet; Heym M,R (-делие); Slov.Ak.Ross.1822; in der Volksdichtung, Sobolevskij I Nr.337, II Nr.182.

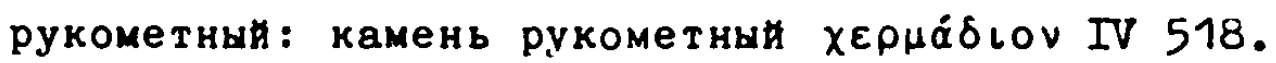
рукомоиник $\lambda \varepsilon \beta \eta \varsigma$ XXIII 613. Bel.bei Srez.; Polik.: vi $\mu \mu \alpha$, $\pi \lambda u v o ̀ s, \chi \varepsilon\llcorner\rho o ́ v \iota \pi \tau \rho \circ v$; Nordstet; Heym M,R; Slov.Ak.Ross. 1822; in der Volksdicutung, hilferding 531. рукомонныи: сосуд рукомоинни $\lambda \varepsilon \beta \eta 5$ XXIII 884.

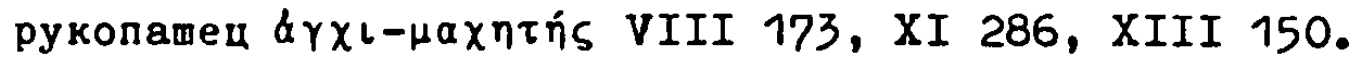

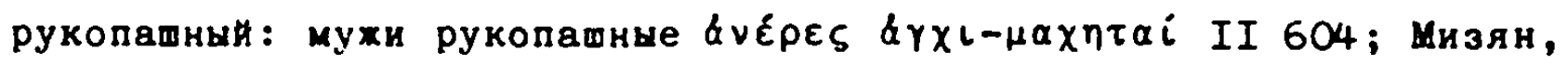

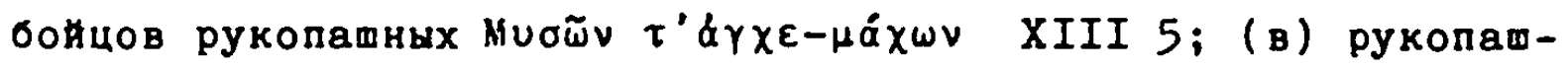

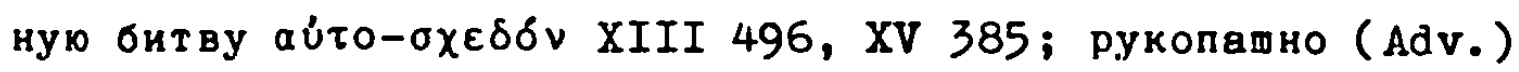

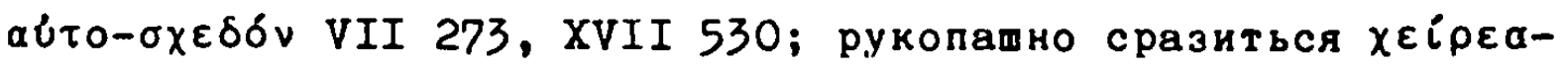

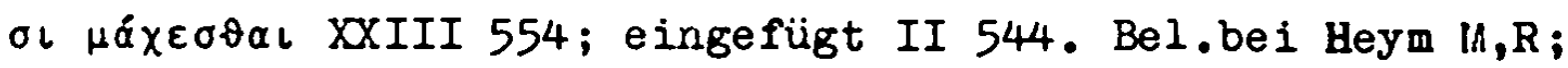
Slov.Ak.Ross.1822; in der Volksdichtung, K.Danilov 361, Hilferding 1084, 1173, Sobolevskij VI Nr.406.

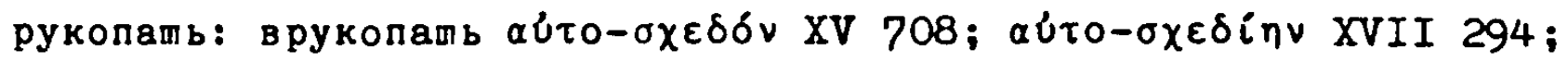

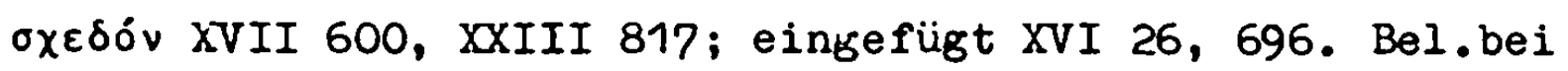
Srez., Hiklosich; Heym H,R; Slov.Ak.Ross.1822.

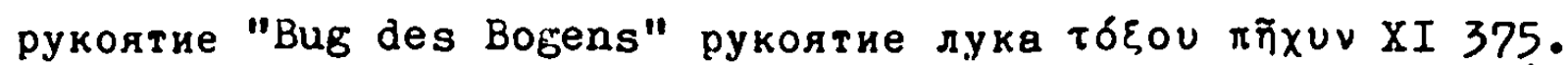

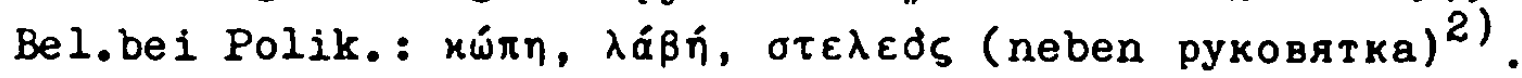

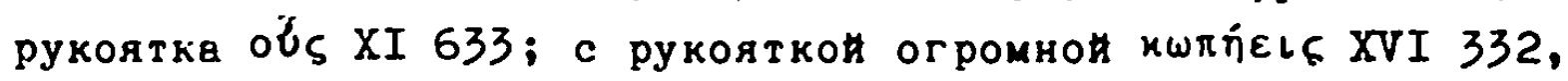

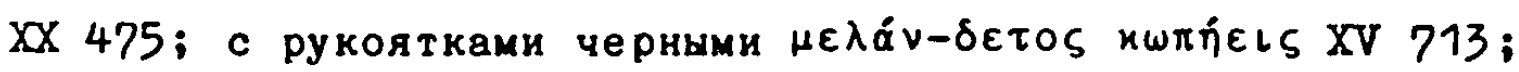

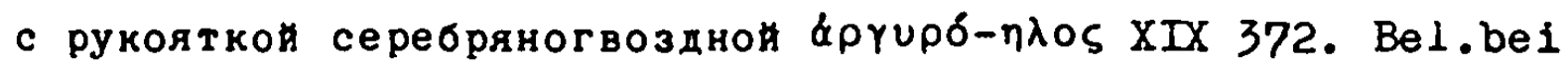
Weißmann; Ross.Cell.; Nordstet; Heym M,R; Slov.Ak.Ross. 1822.

1.Srez.und Polik.verz.nur maskul. рукодельник.

2.Dagegen verz.Miklosich, Heym M, R, Slov.Ak.Ross.1822, Sokolov das "Wort mit der Bedeutung "Garbe". 
рукоять "Griff": и до самойему рукояти Меч погрузился во

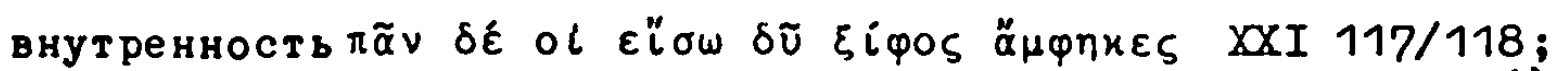
ohne Entspr. XI 29. Bel.bei Sokolov in der Bed. "pучка"1).

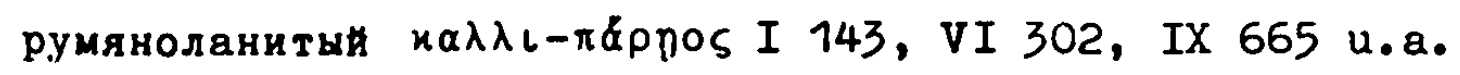
руноносны (овца, стадо) єlро-то́кољ V 137; sinngemäß eingefügt XI 222.

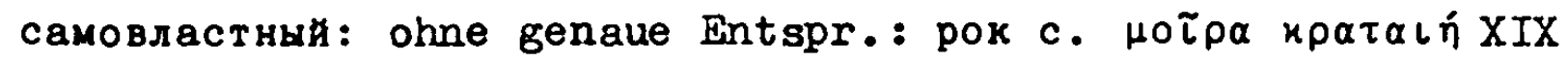
410; деву...самовластно исторгнул царь Агамемнон тオレ...

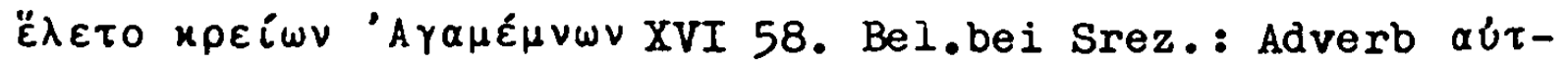

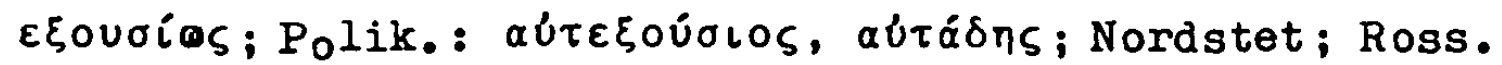
Cell.; Heym M,R; Slov.Ak.Ross.1822.

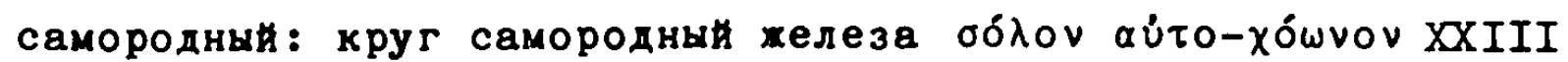

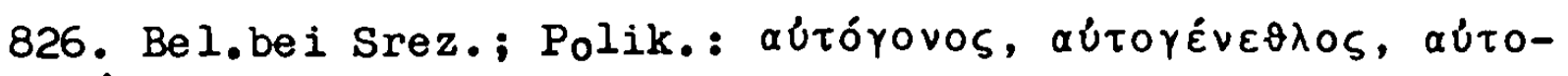
revìs; Ross.Cell.; Nordstet; Heym M,R; Slov.Ak.Ross.1822; in aer Volksdichtung, Sobolevskij II Nr.142. самохвал \& $\varepsilon\llcorner\lambda \eta \tau$ VI VII 96. Bel.bei Nordstet; Heym M,S; Slov. Ak.Ross. 1822 .

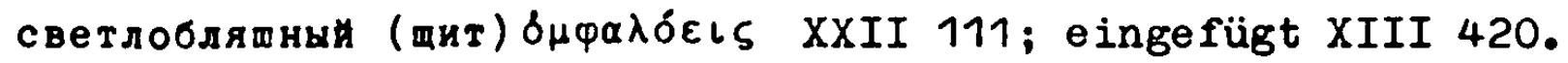
светловласыи: meist auf Menelaos bezogen: $\zeta \alpha$ จо́ 183, XVII 578 u.a.; mit ganz anderer Entspr.: Borv arałós XVII 246, 656, 665; eingeschoben XVII 626. Bel.bei Deržavin, Разнве вина.

светловодны हैU-ррєи́s XXIV 692. светлокудрын: meist auf Menelaos bezogen: ६avoós II 642, III 434, IV 210 u.a.; ohne Entspr.eingefügt XXIII 566. светломастнын (кобылица) ६аvөо́s XI 679. светдоокић $\gamma \lambda \alpha u x-\tilde{\omega} \pi\llcorner\varsigma$ I 206, II 172, 279 u.v.a.; mit anderer

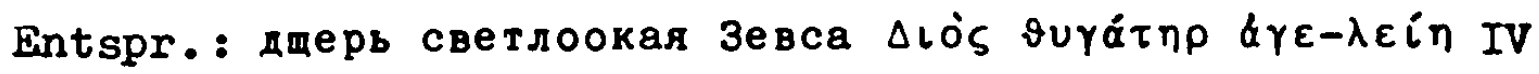
128; ohne genaue Entspr.sinngemäß eingeschoben: светлоокая

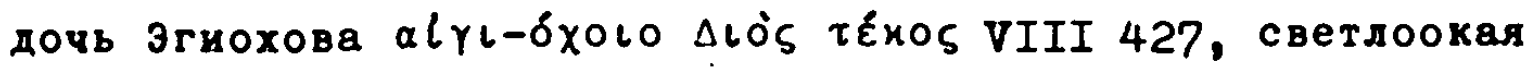

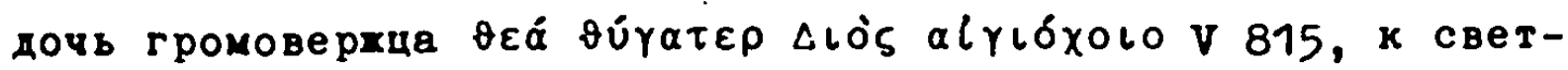
доокон Афине 'Aөпvaínv IV 69.

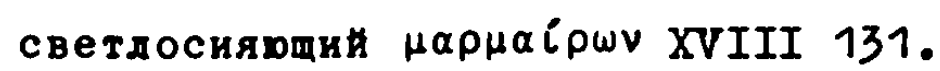

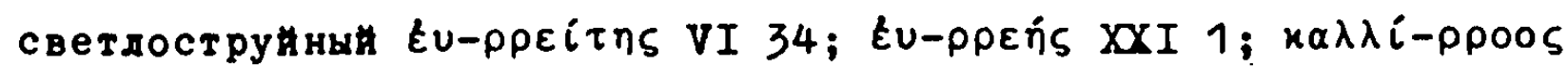

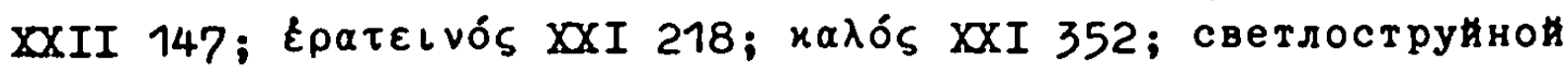

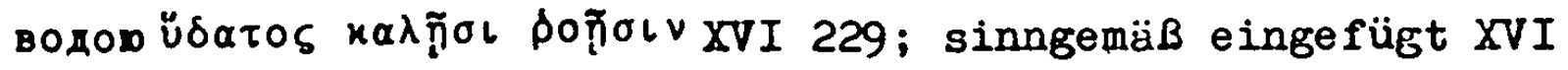

1.Srez., Polik., Nordstet, Heym M,R, Slov.Ak.Ross.1822 geben die Bedeutung "Garbe". 
669, 679. Bel.bei Trediakovskij ${ }^{1)}$. свветозарныи (очи, солнце, щит, шелом, треног und ähnliche).

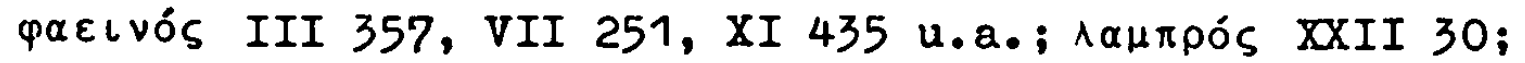

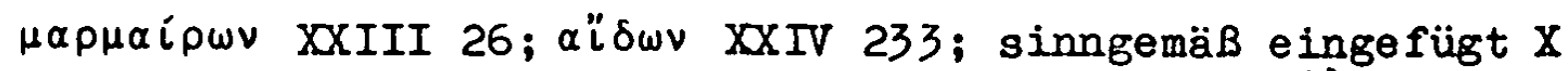
547, XXIII 799. Bel.bei Srez.; Sime on PoIockij; ${ }^{2)}$ Nordstet; Heym M,R; Slov.Ak.Ross.1822. свветоносей 'Fwo-фópos XXXIII 226. Bel.bei Srez. und Polik.:

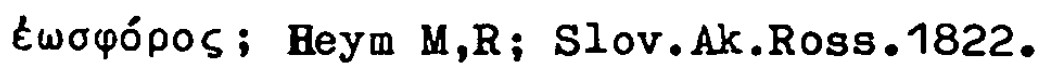

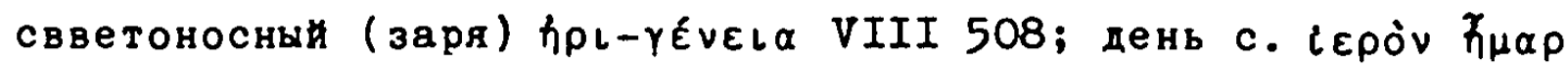
VIII 66, XI 84. Bel.bei Srez.: poopópos; Nordstet; Heym M, R; Slov.Ak.Ross.1822. сввинопас бU-үорßós XXI 282. Bel.bei Ross.Cell.; Heym M,R; Slov.Ak.Ross.1822. Сввирепогордящићся: Сьн Панфоя, свирепогордящићся, звучно вос-

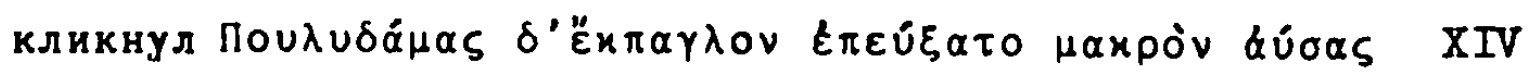
453.

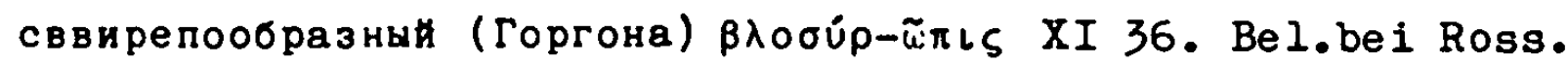

Cell.; Nordstet; Heym M,R; Slov.Ak.Ross.1822. сеедовласын ohne Entspr.eingefügt als Attribut zu Nestor II 77.

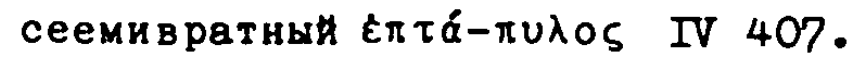

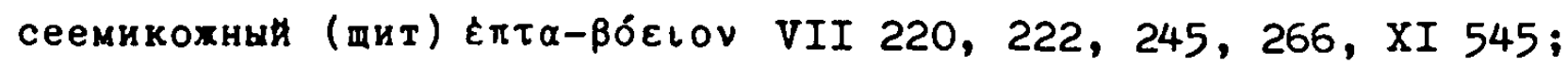
mit anderer Entspr.: $\mu \varepsilon ́ \gamma \alpha \varsigma$ XI 572, XXIII 820.

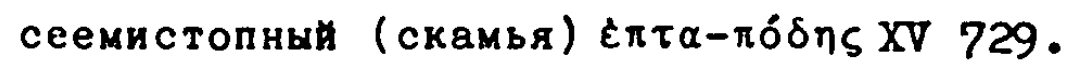

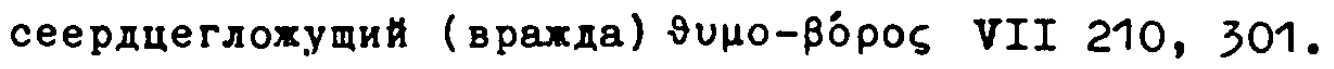
сееребристопучинны s.u. сребристопучинный. сееребряногвозднын s.u. среброгвозднын. сееребрянолистнын: тополь с. \&хершіs XIII 389.

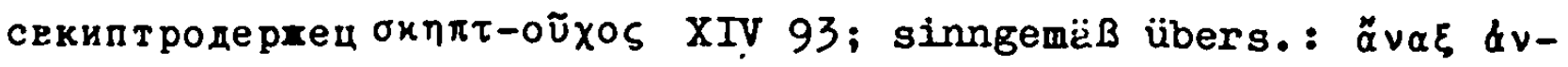

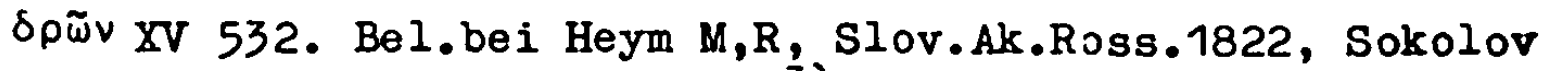
in der Lautung скипетродерхец 3 ).

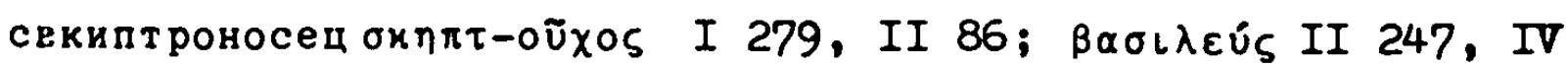

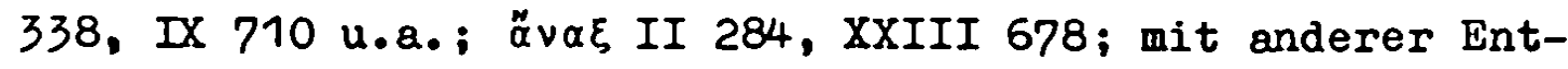
spr.: $\delta$ Ios II 221; ohne Entspr.eingefügt II 197, XXIII 289.

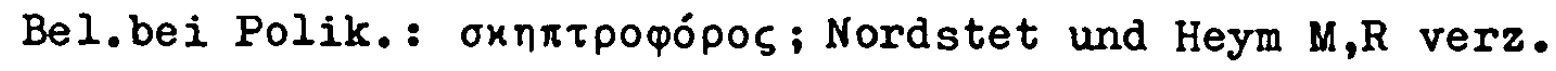
скипетроносец.

1.Vgl.Hüttl-Worth S.18, 185.

2.Vgl. TschiZewskij Zfsiph Bd.17, S.144 ff.

3. Bei Trediakovskij findet sich скиптродеркащин,vgl.HüttlWorth S.18. 


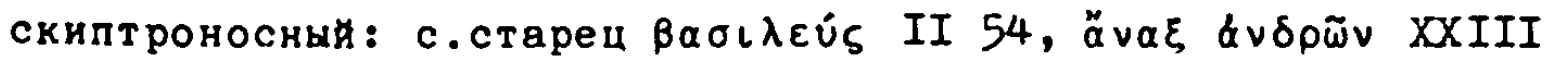
895.

скудоумны $\alpha$-фршv II 220. Bel.bei Heym R; Slov.Ak.Ross.1822. Srez. verz. скудноумный.

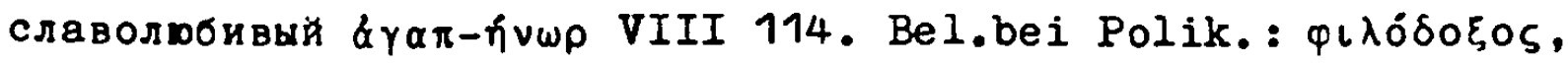

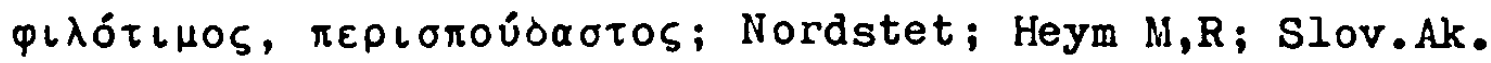
Ross. 1822.

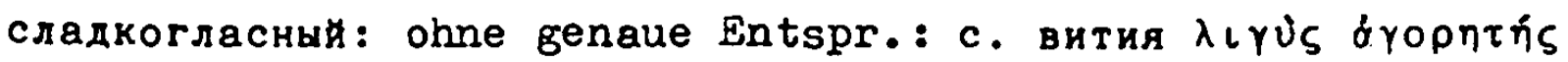
IV 293. Bel.bei Polik.: riuxúqwvos; Nordstet; Heym M,R; Slov.Ak.Ross.1822.

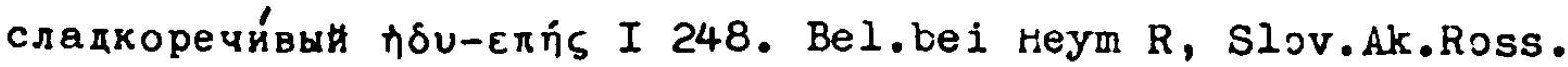
1822, Sokolov. Nordstet und Heym ii verz. mit anderem Akzent слалкоре́чивый.

сладострастніи: наслілдяется ею Царь сладострастный тй $\pi \alpha \rho-$

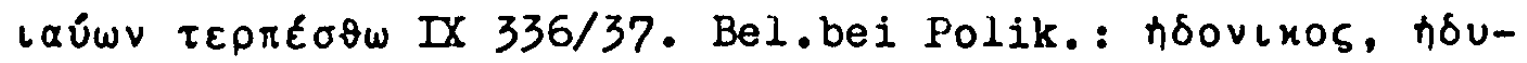
$\pi \alpha \theta$ ris; Nordstet; Heym R; Slov.Ak.Ross.1822.

смертоносний $\dot{\omega x u ́-\mu о р о \varsigma ~ X V ~ 440 ; ~ \theta U \mu о-\beta о ́ \rho о \varsigma ~ X V I ~ 476 ; ~ \beta р о \tau о-\lambda о \iota-~}$

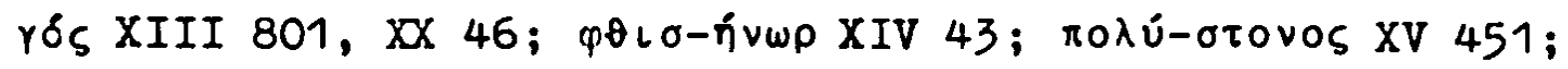

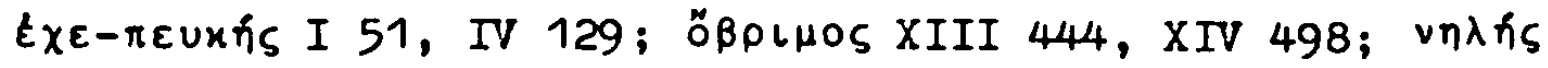

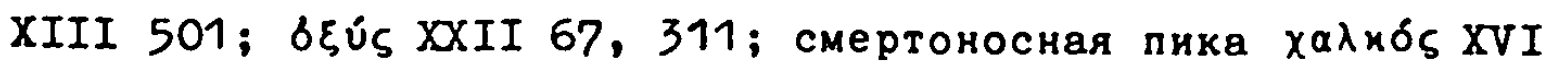
309; ohne Entspr.eingefügt XXII 327; zusammen mit Bez.Hort

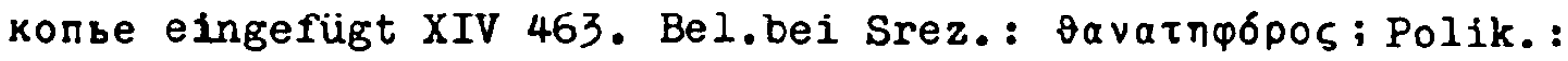

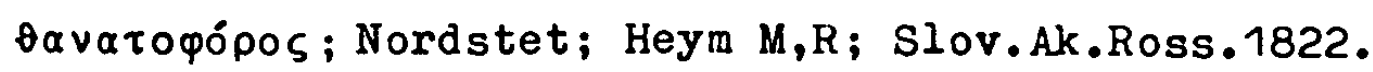

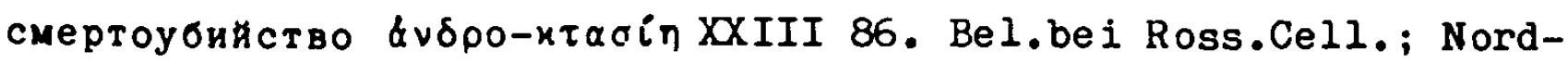
stet (neben смертноубинство); Hеуm M,R; Slov.Ak.Ross.1822. сновидение ӧvар X 496. Bel.bei Heym $M, R$; in der Volksdichtung,

K.Danilov verz. das Dimin. сновиденьице, S.284. сребристоблестяши: закрывшись покровом сребристоблестящи

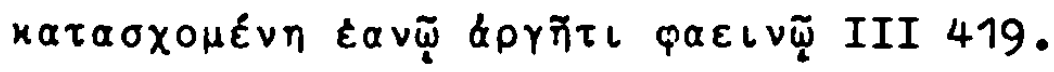

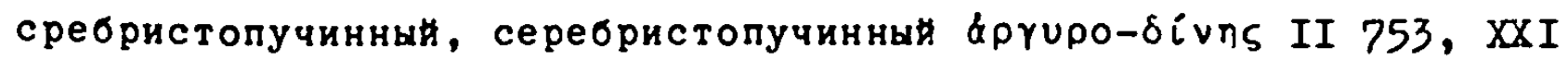

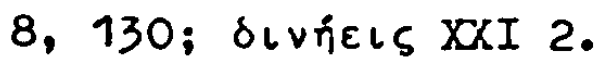

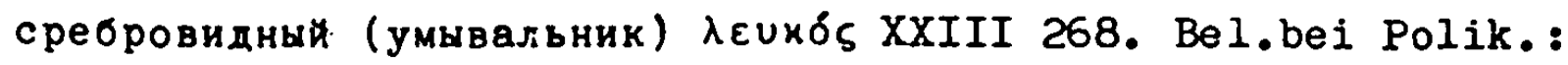
¿pүupoeloths; Heym $\mathrm{M}, \mathrm{R}$; Slov.Ak.Ross. 1822. среброгвоздның, серебряногвозднын (меч, нок, трон) брүирб$\eta \lambda \circ 5$ II 45, III 334, VII 303, XVIII 389 u.a.; mit anderer

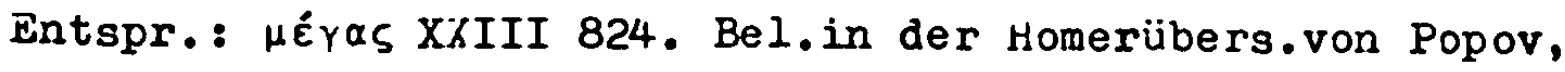
vgl.Jegunov S.198. среброковны (ларец) \&рүи́рєоऽ XVIII 413. 


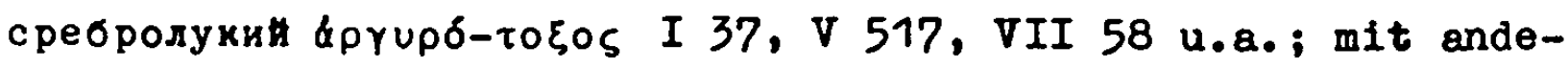

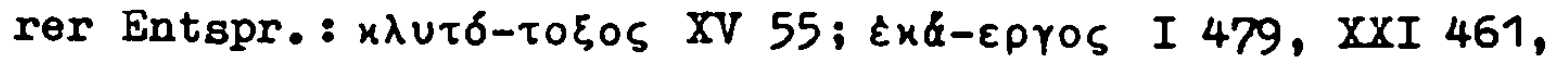
478; $\varepsilon x \eta-\beta \delta \lambda$ ОS XVI 514; 'А $\delta \delta \lambda \omega \omega V$ I 380; Аполлон c. oder Феб с. ФогвоS 'A $\delta \lambda \lambda \omega V$ I 43, 457, XX 376,XXIV 32; дально-

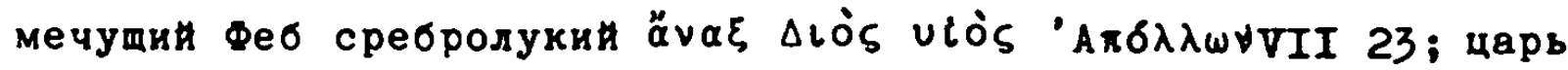

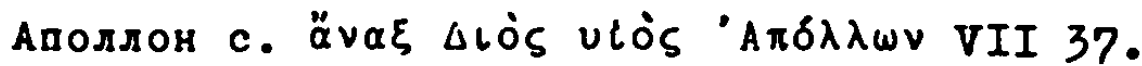

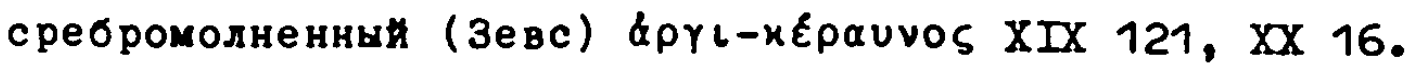

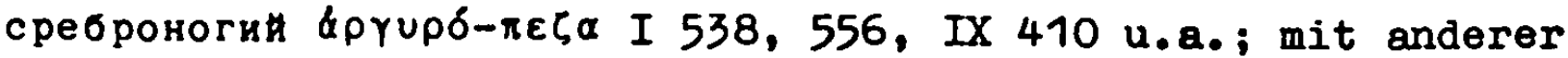

Entspr.: hú-xоноS XVI 860; eingeschoben XIX 20, XXIV 562.

Bel.in den Homerübersetzungen von Kondratovic und Kostrov, vgl.Jegunov $5.47,95^{1)}$. сребропламеннын (перун) \&рүи́s VIII 133.

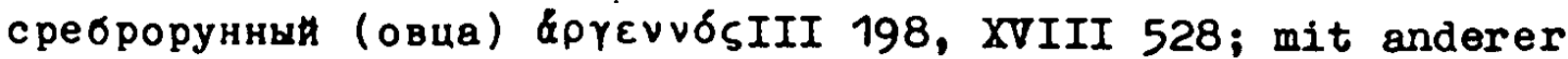
Entspr.: iфı०S IX 406; ohne Entspr.eingefügt XXII 501;

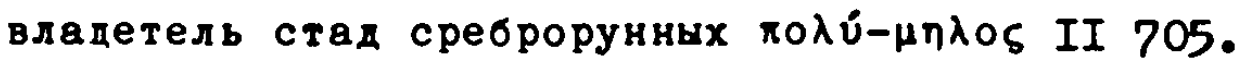

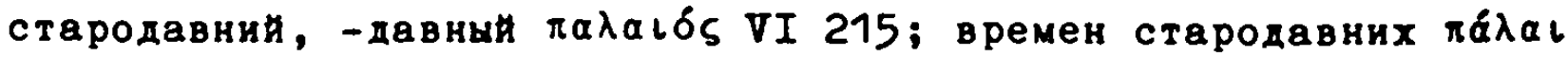
IX 527. Bei Polik. (dpxaĩos, \&pxaıórovos), Heym M,S, Slov. Ak.Ross.1822, Hilferding 683, 1132, 1266, Golovack1f III Teil 2, 25, Sobolevskij VII Nr.323, 324 ist стародавньн verzeichnet, Sobolerskij gibt auch die weiche Endung, VII $\mathrm{Nr} .322,329$.

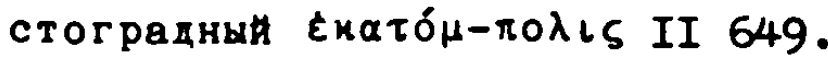
стократнын: ohne genaue Entspr.: стократно сихьнейин $\mu \& \lambda \alpha$

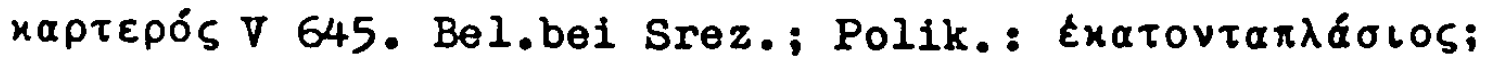

Ross.Cell.; Nordstet; Heym M,R; Slov.Ak.Ross.1822.

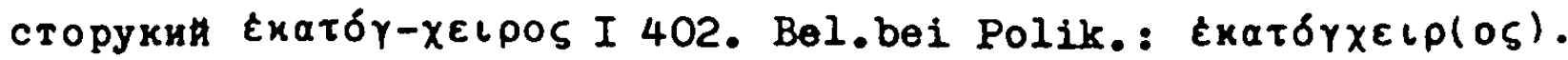

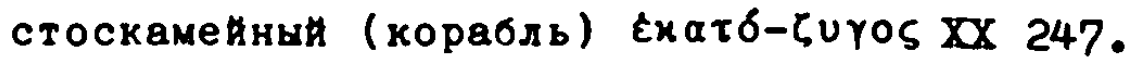

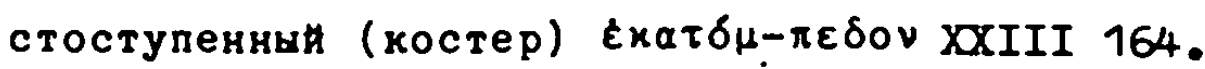

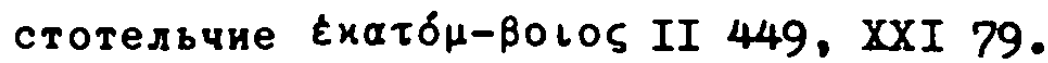

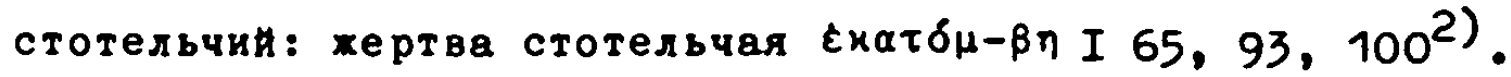

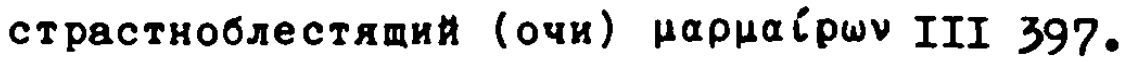
стрелобоиныи: ohne genaue kntspr.: искусный в бор стрелобон-

1.Bei Jekimov findet sich сребряноногая Фетида, vgl.Jegunov S.59.

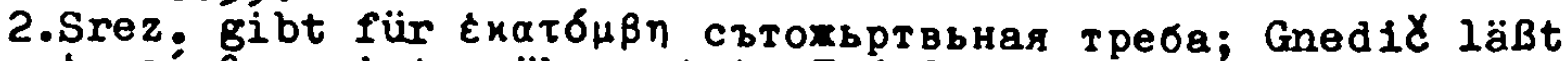

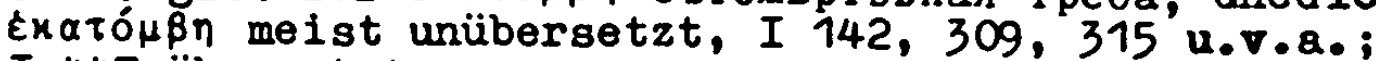
I 447 übersetzt er rекатомбная хертва. In der Ii iasübers. von Kostrov findet sich стотельнн дap, in der Odysseeübers. von Krylov стотельчная хертва, vgl.Jegunov S.96, 301. 


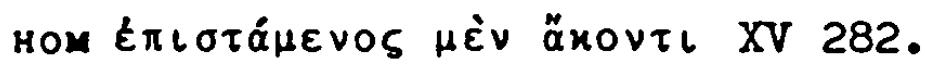
стреловерхец $\varepsilon x \alpha \dot{\alpha}-\varepsilon \rho \gamma о \varsigma$ I 474, IX 564, XVII 585; sinngemäB

übers.: 'A geschoben I 49, VIII 322, XV 239, XVI 706.

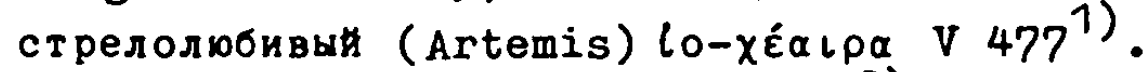

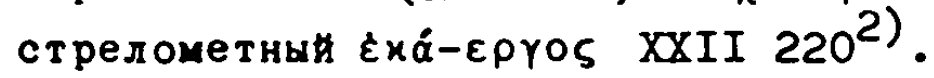
стрелоноснн: sinngemäß übers.: стрелоносного Феба фоїои

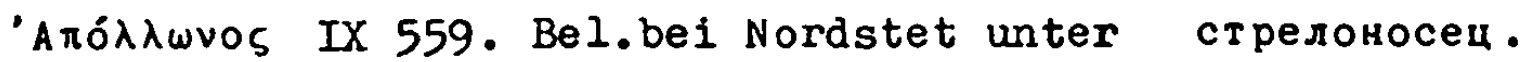

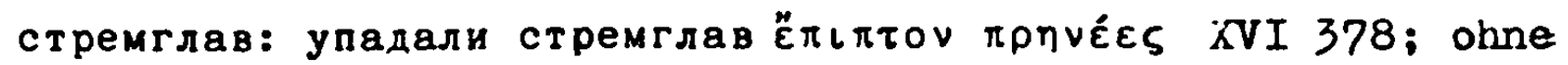

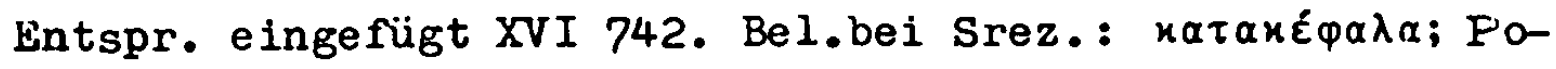

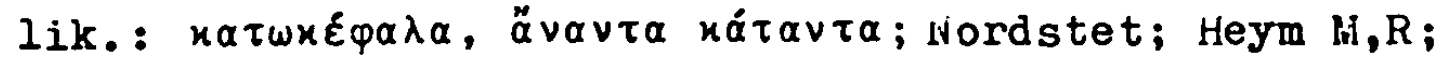

Slov.Ak.Ross.1822. твердоброннын эшрпити́s XV 739.

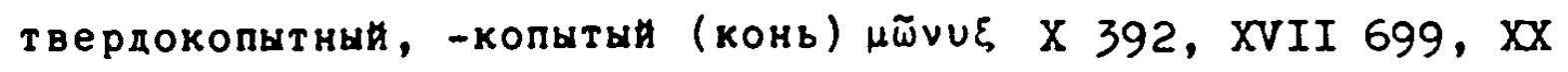
498, XXIII 550.

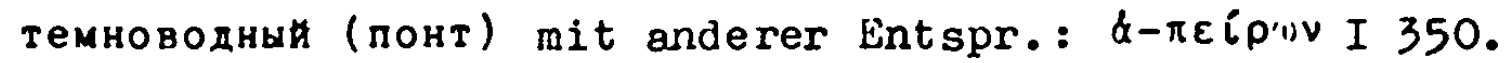
темносиния (ров) ииа́veоs XVIII 564. Bel.bei Srez.; Nordstet;

Slov.Ak.Ross.1822.

темночелын (вол) ohne Entspr.eingefürt XX 403.

тиховенны: ohne genaue intspr.eingefügt: зыблот еe, прохлак-

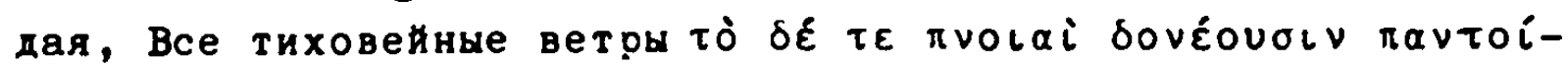

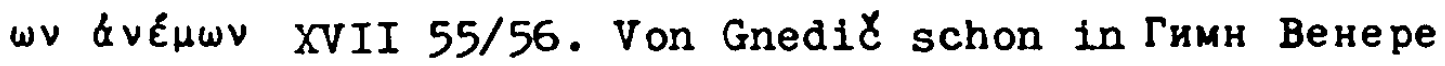

(1807?), einem der Homerischen Hymnen, gebraucht. Bel.ferner bei Batjuskov in Мои пенаты.

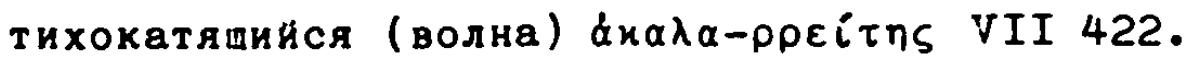

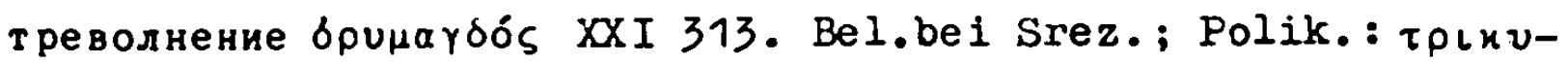

$\mu i \alpha$; Nordstet; Heym M,R; Slov.Ak.Ross.1822.

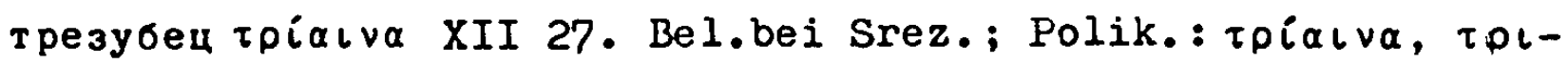
ocoviia Nordstet; Heym H,R; Slov.Ak.Ross.1822.

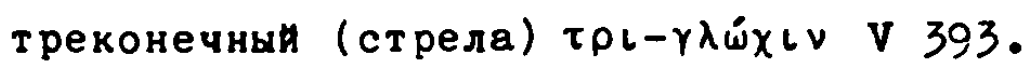

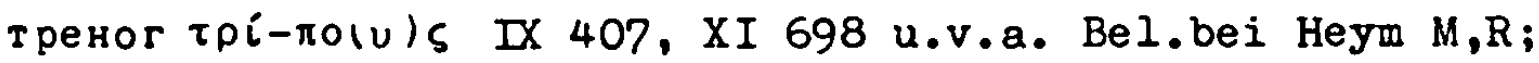

Slov.Ak.Ross.1822.

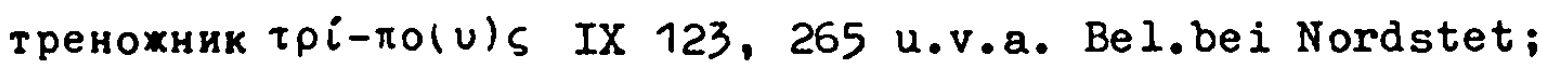

Heym H,R; Slov.Ak.Ross.1822.

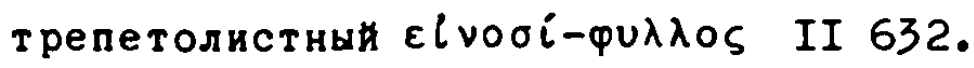

1.Srez. verz. стрелолюбец.

2.Jekimov prägt стрелометница, Kostrov стрелометатель, vgl.Jegunov $\mathrm{S.59}, 96$. 


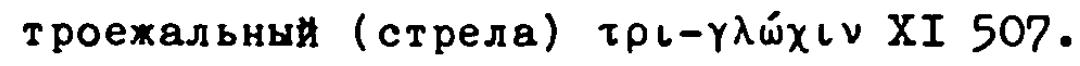

троекратның $\tau$ рis XXII 165, XXIV 686. Bel.bei Nordstet; Heym

$M, R$.

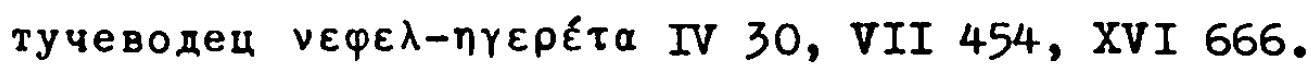

тучегонитель

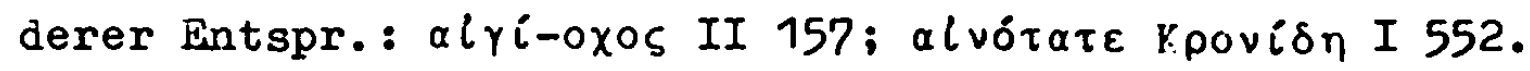

Bel.bei Krylov in Бoray и Поэт.

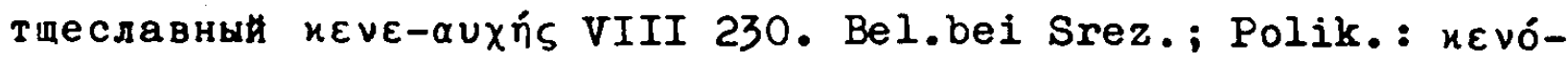

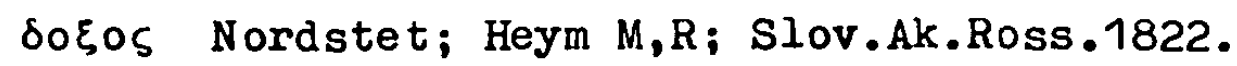

тьмочисленныи (овцы) ниріац IV 434. Bel.bei Srez.Suppl. Heym

$M, R$ und Slov.Ak.Ross.1822 verz. тмочисленный.

тяжконоги (вол) $\varepsilon(\lambda i-\pi о$ Хर XVI 488; ohne Entspr.eingefügt XI

548.

усердносоветныи: ohne genaue Entspr.: Будешь ли ты мне по-

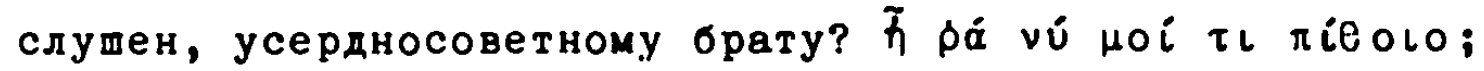

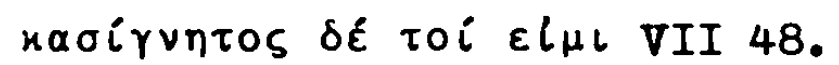

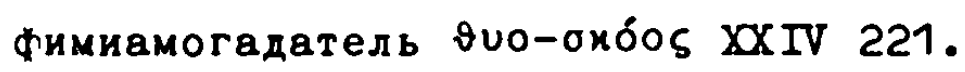

хит роизмышленный (ручка) $\alpha\llcorner\delta \alpha ́ \lambda \varepsilon о 5$ XVIII 379.

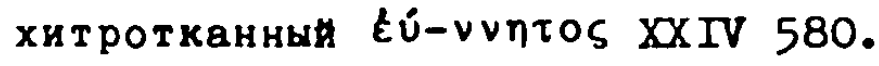

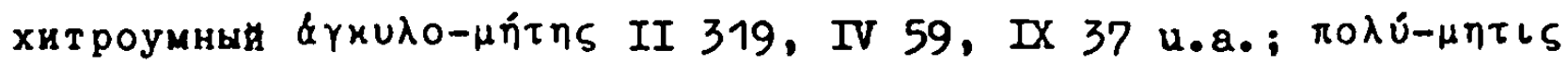

$\mathrm{X} 488$.

хитрошвенның (ремень) поли́-хєотоб III 371.

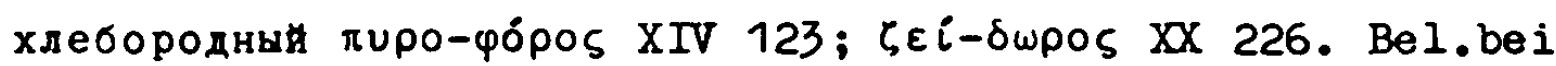

Nordstet; Heym M,R; Slov.Ak.Ross.1822; in der Volksdich-

tung: Sobolevskij I Nr.230, III Nr.113 u.a.

хоровод хоро́s III 393, 394, XVIII 590; знаменитые...в хоро-

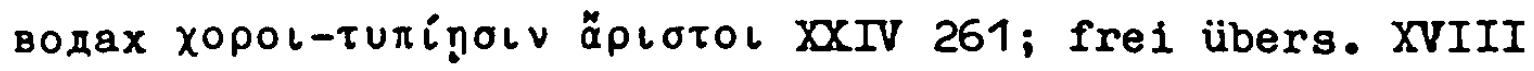

572. Bel.bei Heym M,R; Slov.Ak.Ross.1822; in der Volks-

dichtung: Hilferding 402, 403, Sobolevskij I Nr.171, $\mathrm{Nr}$. 475, II Nr.145 ${ }^{1)}$.

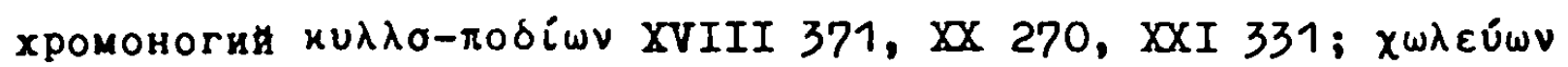

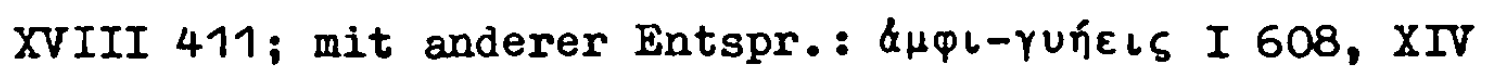

239, XVIII 393; ohne Entspr.eingefügt XX 12. Bel.bei Nordstet; Heym M,R; Slov.Ak.Ross. 1822.

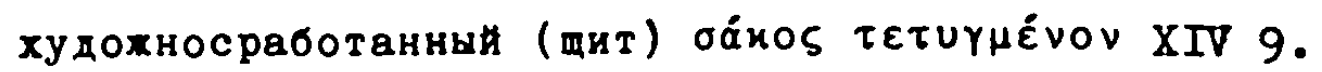

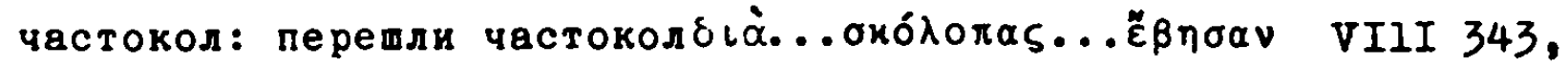

1.Daneben findet sich die Lautung коровод II Nr.130. 


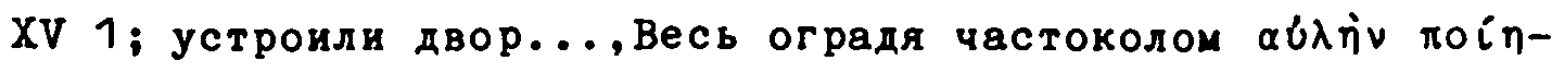

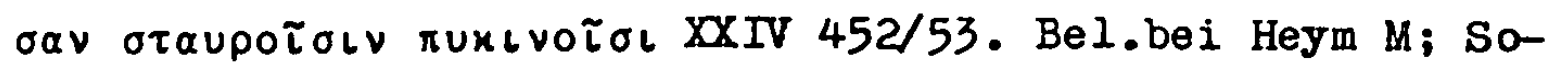
kolov; in der Volksdichtung, Golovackij II 51 (in der Lautung чистокол).

чернобокин (корабль) не́лаS IX 654.

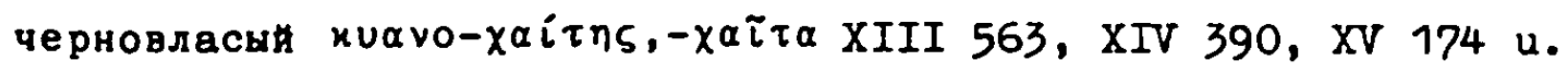

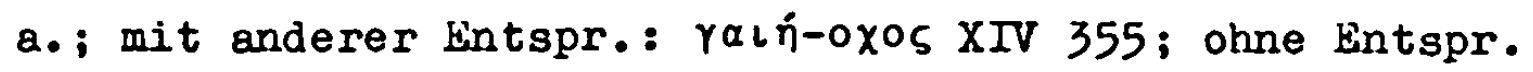
eingefügt XX 149. Bel.bei Nordstet; Heym M,S.

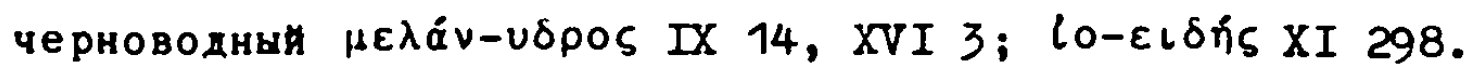

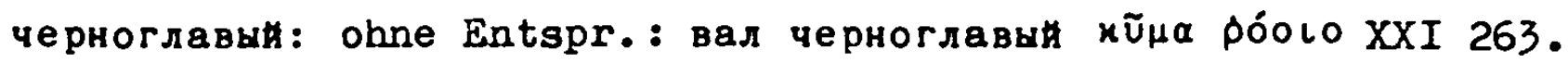
черноголовын: $3 а$ ним он ударил Валом черноголовым шрто $\delta^{\prime} \varepsilon \pi^{\prime}$

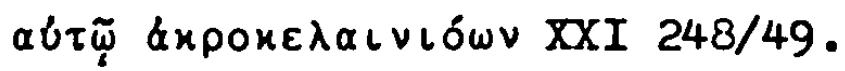

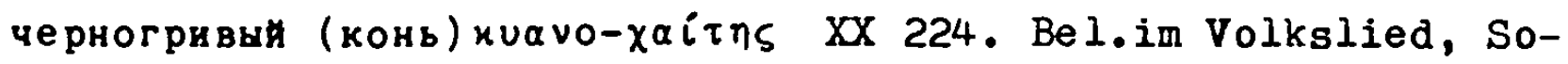
bolevskij VII Nr.481, Golovackij I 111. черноносын (корвбль) киа ио́-лрџро丂 XV 693, XXIII 852, 878.

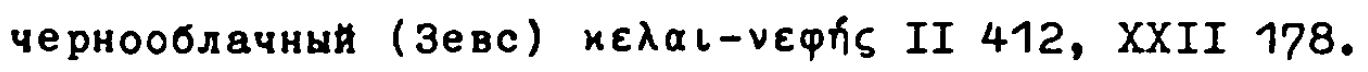

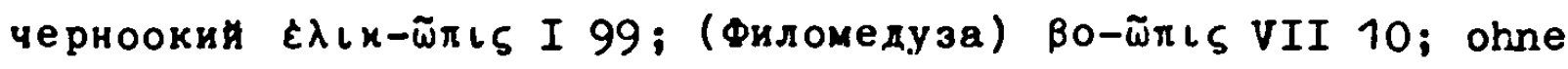

Entspr.eingefügt I 112, XI 82. Bel.im Volkslied, Golovackij I 338, III Teil 1, 440. черноперы (орел) не́лаS XXI 252. Bel.im Volkslied, Sobolev-

skij V Nr.693.

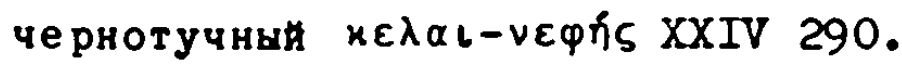

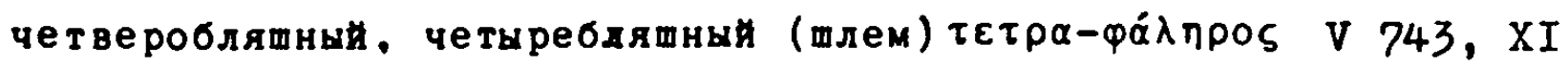

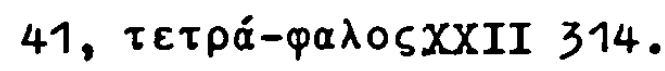

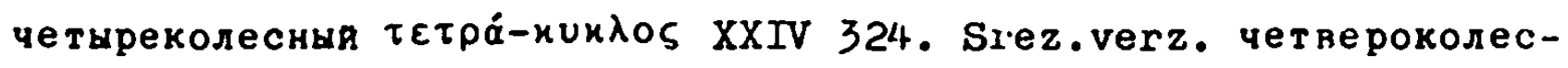
н世म.

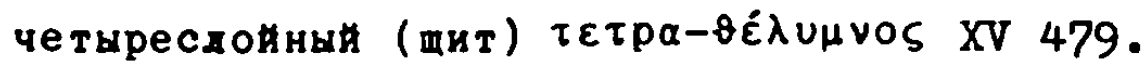

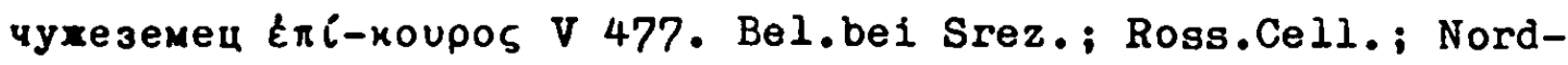
stet (unter чyхестранец als Variante); Heym M,R; Slov.Ak. Ross.1822. чухеземкв ӓ $\lambda \lambda \eta$ VI 456. Bel.bei Sokolov unter чухеземец.

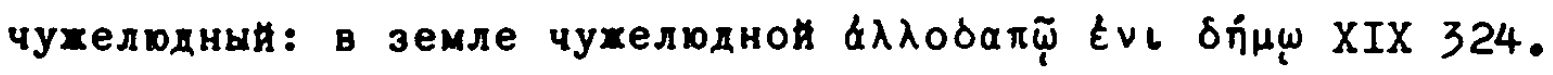
шестигодово $\varepsilon \xi-\varepsilon \tau \eta$ XXIII 265. шестилетнин $\varepsilon \xi-\varepsilon \tau \eta$ XXIII 654. Bel.bei Nordstet, Heym H; bei

Polik. ( $\varepsilon \xi \alpha \varepsilon \tau \dot{r} s)$ und Heym $R$ mit harter Endung.

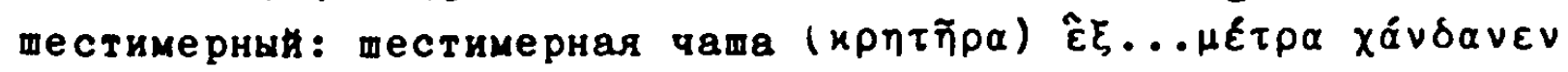
XXIII 741.

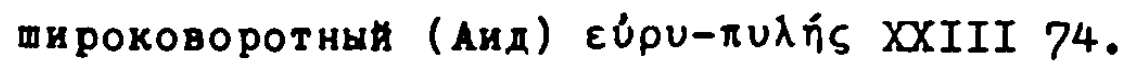




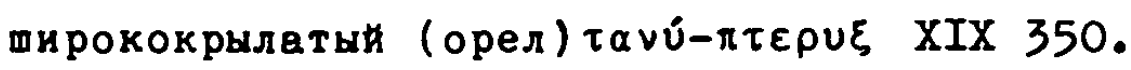

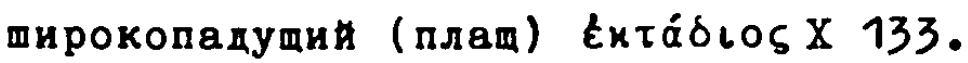

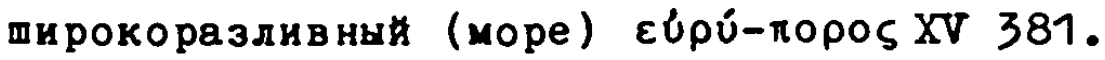

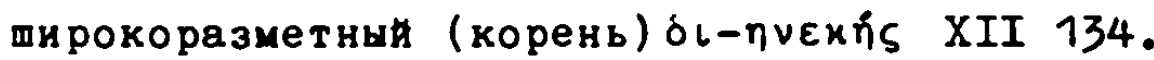

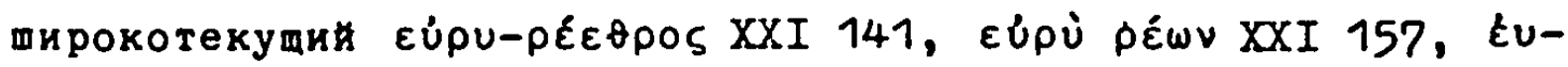
ppeñs VI 508.

широкоустроеннн (Knossos) єúрús XVIII 591.

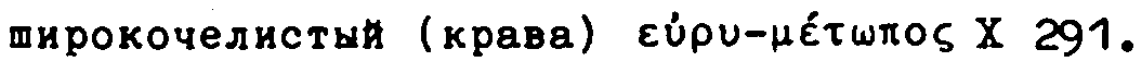
шлемоблещущи (Гектор) иориө-аіодоร II 816, III 83, V 680 u.

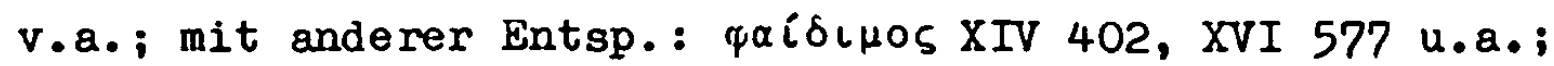
ohne Entspr.eingefügt VIII 341, XI 347.

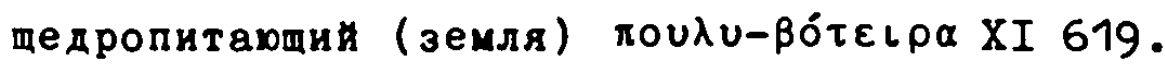

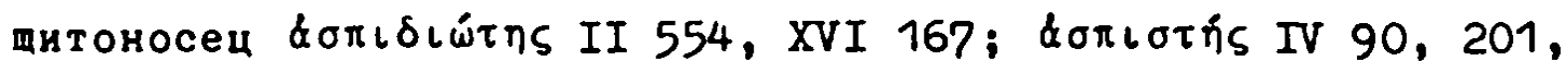

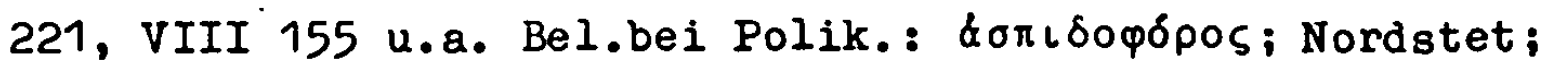

Heym $\mathrm{M}, \mathrm{R}$.

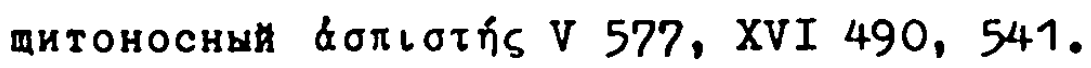

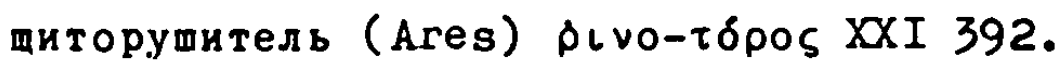

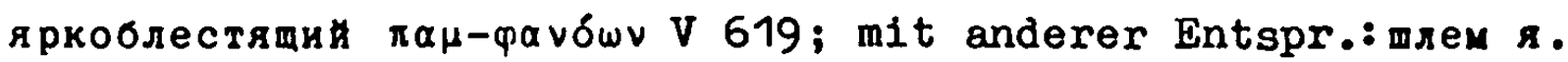

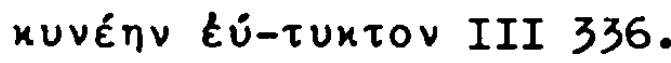

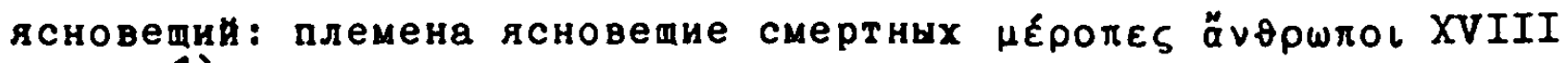
$288^{1)}$.

ясноглаголивн не́роф II $285^{1)}$. Bel.bei Nordstet; Slov.Ak.

Ross.1822. Das Wort ist also kein Neologismus von Gnedil, wie Kukulevič a.a.0.S.51 f. behauptet.

яснооки: ohne Entspr.eingefügt: с ясноокон Афиной бйv 'A vฺ III 439.

ясноречивн церо XVIII 4901). Nordstet führt unter ясноглаголивы als Variante ясноречивын an.

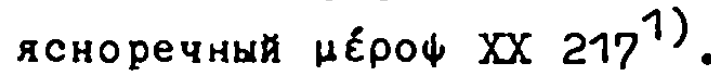

1.Gnedid fußt hier also auf einer älteren Etymologie "artikuliert sprechend", von $\mu \varepsilon \rho i \zeta \varepsilon \iota v$ und ö $\psi$. 


\section{B. Auswertung des Materials \\ I. Gnedił variiert gern.}

1. Er übersetzt ein und dasselbe griechische "Iort auf verschiedene Weise: ${ }^{1)}$

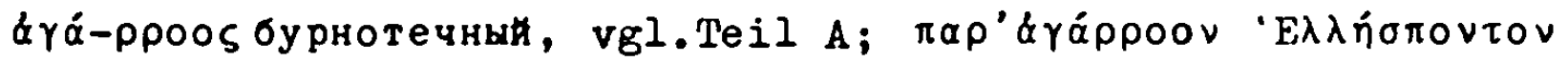

до стремительных волн Геллеспонта XII 30.

$\alpha$ lүi-охоS громоверхец, громоверхущй, громоносный, молненос-

ныи, тучегонитель, всесильның, vgl.Teil A; эгиды носитель

II 348/49, эгида носитель XV 175; метатель молнии V 693;

молнин метатель $\nabla 714$; грома метатель XI 66; вздыматель

облаков XXI 420; великин VI 420; Кронид II 787, III 426;

unübersetzt: X 553, XII 209; das griechische Wort ist

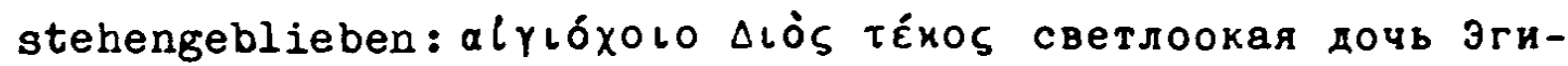

охова VIII 427; $\Delta l o ̀ s$ \&. отца Эгиохова VIII 384.

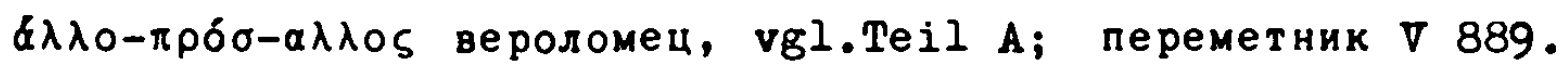

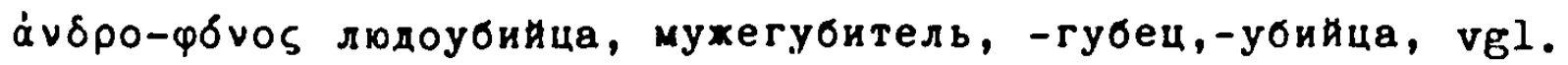

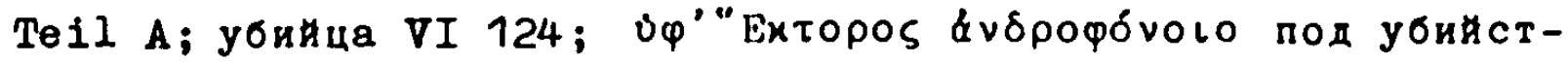

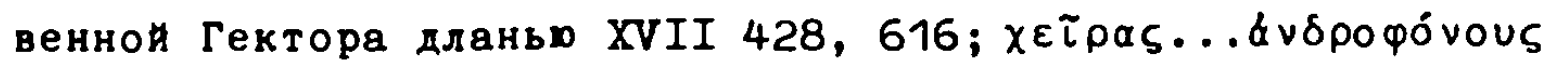

грозные руки XVIII 317, XXIII 18.

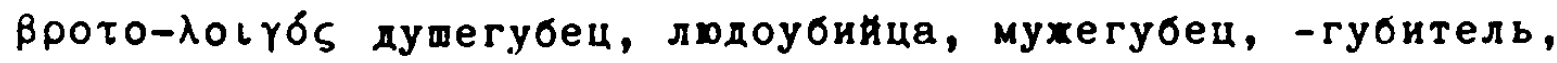

смертоносныи, vgl.Teil A; смертных губитель $\nabla 518,846$,

XXI 421; человеков губитель XI 295, XIII 298; истребитель

народов V 31, истребитель V 9092).

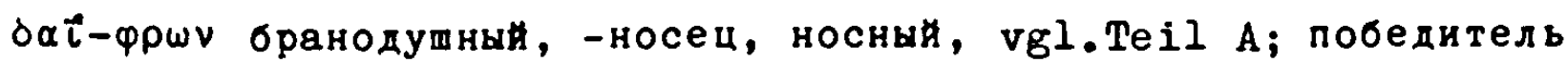

II 875, воинственны IV 93, V 277 и.а.; о отвахнын IV 252;

мух бесстрашның IV 370; могучия V 181, XI 456; великии в

бранях V 813, великии XVIII 30; непорочнын VI 162; пре-

мудрын VI 196; герон X 402, XI 839 и.а.; геронский XIV

459; храбрын XI 791, XV 239, XXIII 405; храбрыи,любезнын

XVIII 18; врехдебның мух XI 138; сильнын XX 267; возница

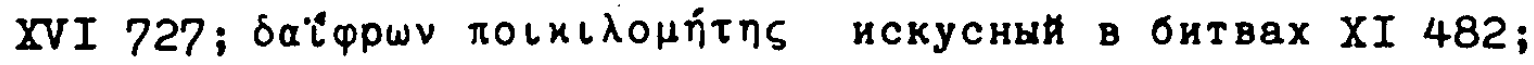

1.Die Ausdrücke werden der Einfachheit halber normalerweise im Nominativ zitiert.

2.Gnedic verwendete das Simplex hier vermutlich, weil, schon

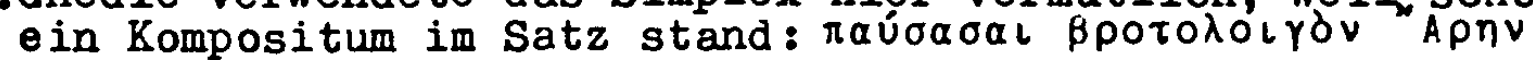

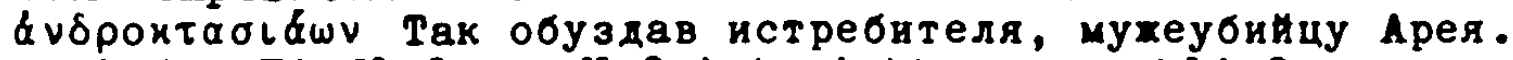
Auch der EinfluB von VOB ist nicht auszuschlieBen; er übersetzt "den Verderber, den männermordenden Ares". 
bei der tbers.unberücksichtigt II 23,60, XI 123 u.a. 1).

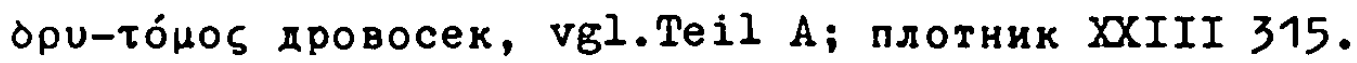

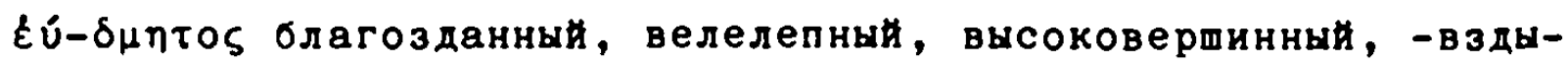

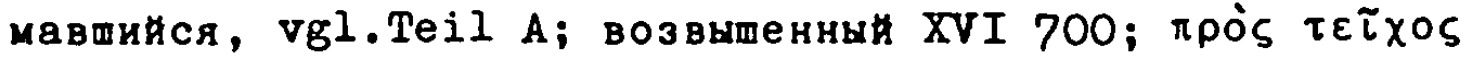

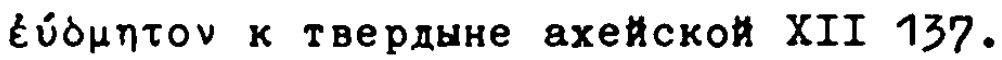

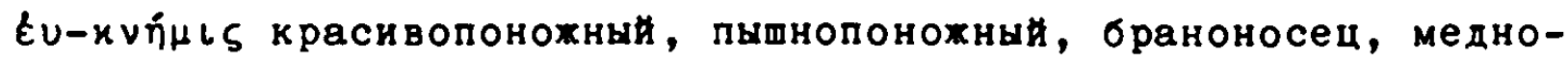
бронның, -доспешныи, -латныи, орухный, -понохныи, vgl. Teil A; блестящин медьо V 668; храбрые мужи III 304; нЕт'

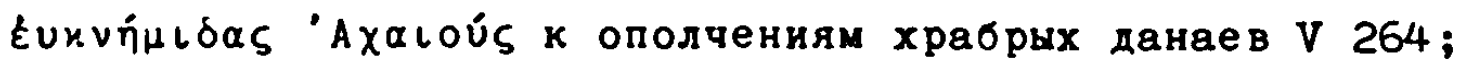

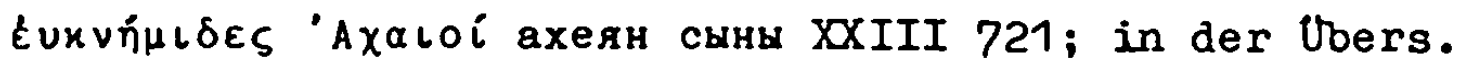
wegrelassen III 156, VII 172, XIX 74. є́-рреп́ быстрольющйся, светловодныи, -струиныи, широкотекущй, vgl.Teil A; прекрасно текущин XIV 433.

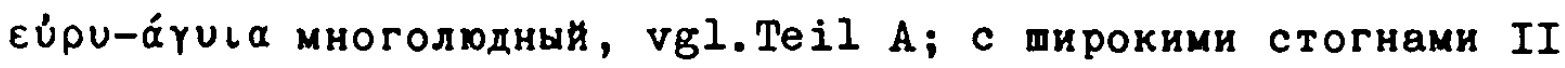

141, IX 28; обширная стогнами II 329.

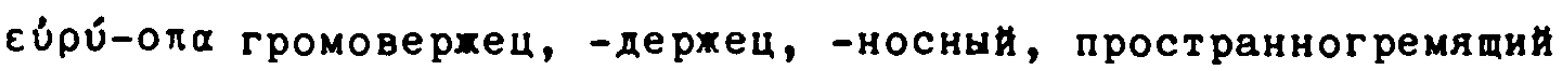

vgl.Teil A; молния метатель I 498, перунов метатель IX 686; беспредельно гремящин XIV 203; промыслитель XVII 545; промыслитель превыспреннын XIII $732 / 31$.

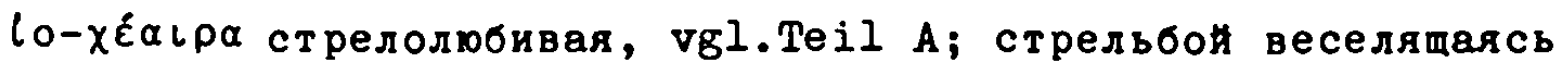
(Феба) V 53, IX 538; гордая лукой XX 39; гордая меткостьо стрел XX 71; Артемида XXI 480²).

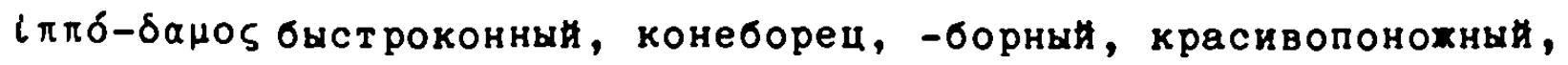
vgl.Teil A; смиритель коне II 23, 60, V 415, 849, VI 299 u.а.; укротитель конен III 237, IV 370, VII 38, 361 u.a.;

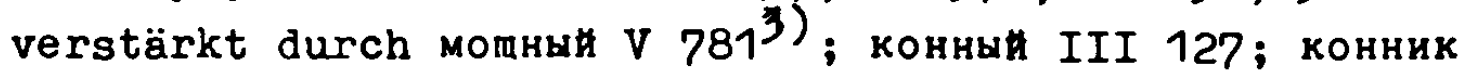
славньй II 230, конник храбрын III 131, 343, IV 80, 355,

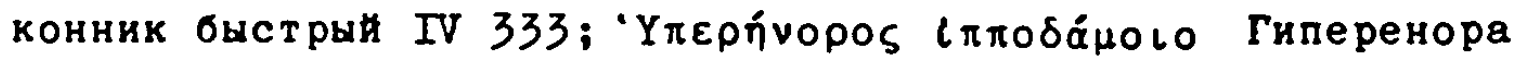
конника, гордого силои XVII 24; колесничник X 431; "Екторо丂 $2 \pi \pi$. Приамова сына XXII 211; überhauptnicht übersetzt XVII 230, XIX 318, XX 180.

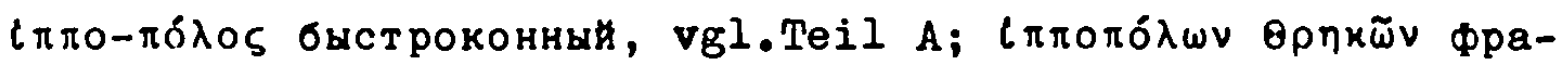
киян, наездников конных XIII 4.

1.Voß übersetzt 2 mal "verständig", 2 mal "erhaben", 2 mal "waltend", 2 mal "mutig", 1 mal "heldenmütig", am häufigsten "feurig"; einige Male läBt er $\delta \alpha^{i} \iota^{\varphi} \rho \omega \nu$ ' unübersetzt.

2.VOB übersetzt immer "froh des Geschosses".

3.Vgl.bei VOB "der gewaltige Rossebezähmer". 


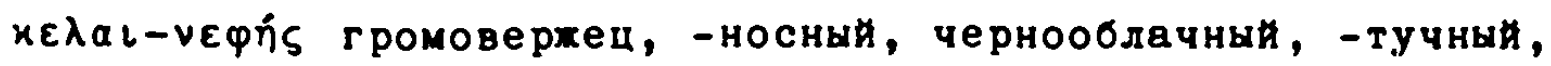
vgl. Teil A; сгуститель облак(ов) I 397, VI 267; гонитель

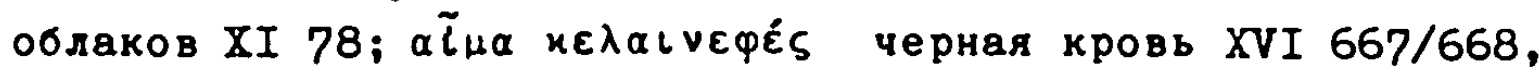
XXI 167; багряная кровь IV 140; кровавая рана V 798; кровь XIV 437 .

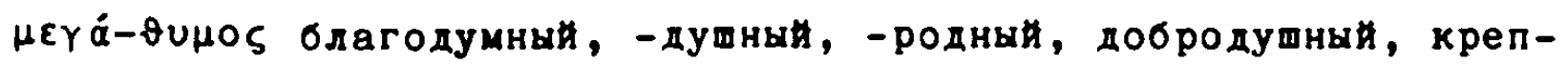
кодушны, vgl.Teil A; возвышеннын духом II 631; высокин духом V 547, XII 379, XVI 594, 818, XXIII 633; нетрепетныи духом II 541; гордын духом XI 731; гордых сердиами IX 549; горды величеством XVI 488; гордын XVIII 335 ; добры в битве V 27; бесстрашны II 706, V 335; храбрын V 534, XIII 456, XIV 454; почтенны XVI 571, XVII 653, XXIII 541; бохественны XX 498; надменны XI 743/44; знамениты XXI 153; великия XVII 214; дерзновеннын V 2351); воеватель могучин V 251); волдь XV 331; друг V 102; герон II 518; sehr

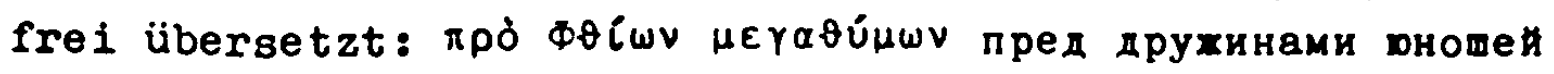
фтинских XIII. 699; unübersetzt I 135, V 577, VIII 155 и.а.

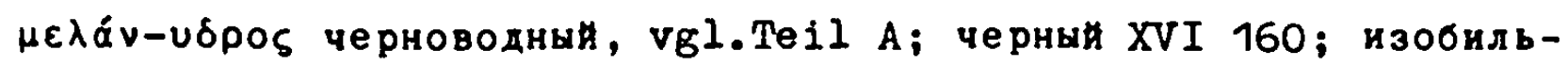
ны влаго XXI 257.

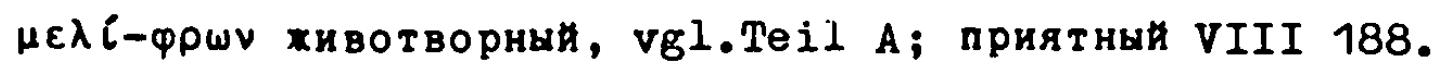

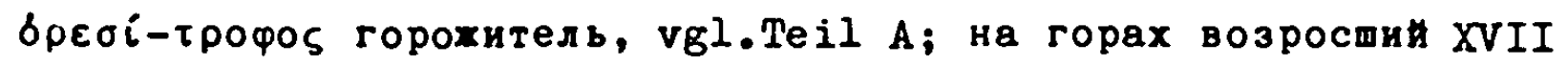
61.

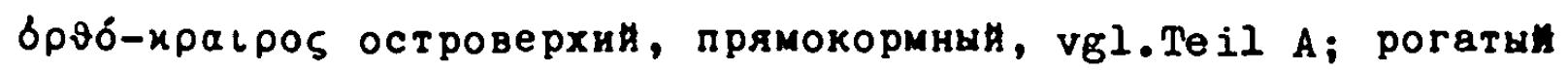

VIII 231; воздымахщи роги XVIII 573.

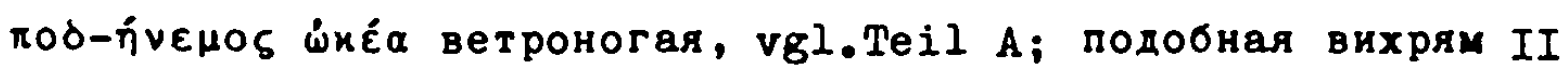
786, XVIII 166; подобная ветрам XVIII 183, 196; равная вихрям XI 195.

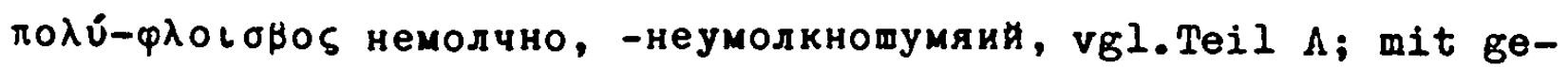
trennt geschriebenen Kompositionsgliedern: немолчно шумящи

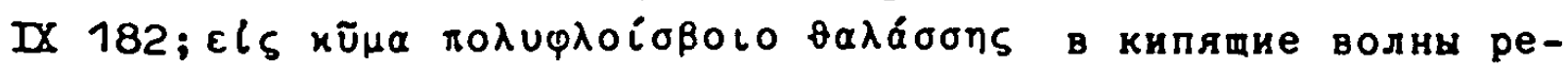
вушего моря VI 347.

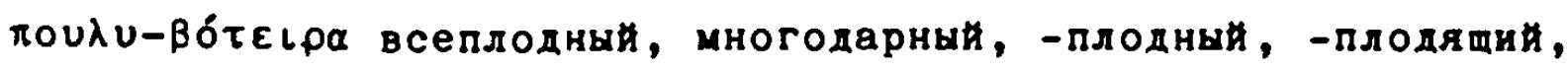
плодоноснын, шедропитающй, vgl.Teil A; злачный III 265 , XXI 426; даровны VI 213, тучны VIII 277; кровавын XII

1.Hit tibertragung der Eigenschaft des Vaters auf den Sohn:

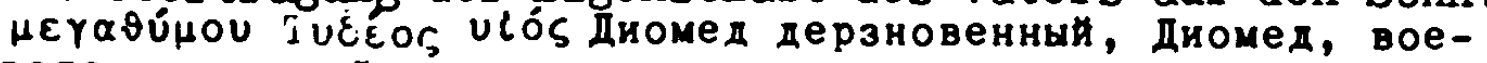
ватель могучй. 
194 ; bei der Ubersetzung weggelassen XXIII 368.

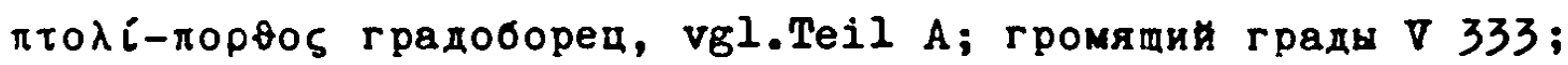

рушитель градов X 363; рушитель тверден XV 77; рушитель стен XXI 550; громитель тверден XX 152. $\tau \alpha \cup \dot{-\pi \tau \varepsilon \rho \cup \xi ~ ш и р о к о к р ы л а т ы н, ~ v g l . T e l l ~ A ; ~ ш и р я ю щ и ̆ ~ в ~ в о з д у х е ~}$ XII 237.

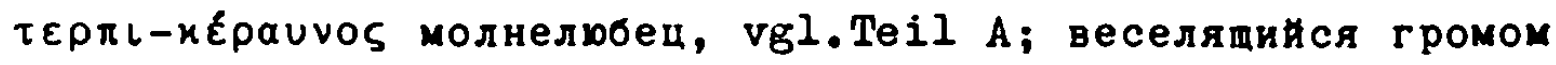
XII 252; метатель грома II 478 , XVI 232; метвтель молния I 419 .

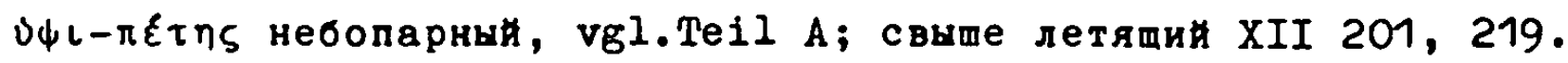

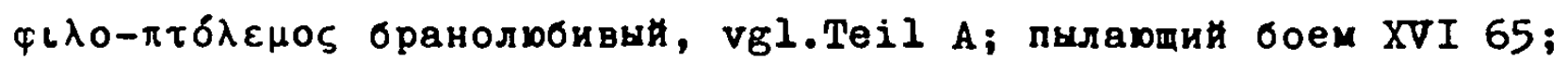

воннственны XX 351, XXIII 5; храбрыи XVI 90, XXI 86;

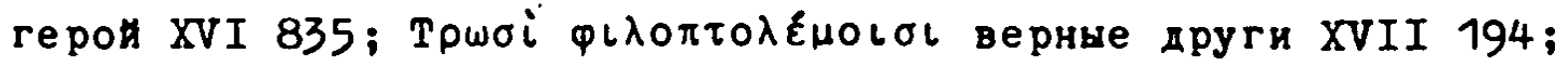

'Apүeíolol ф. мехду сонма данаев XIX 269.

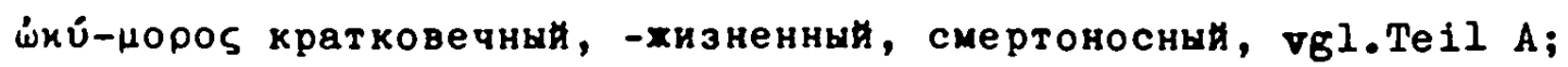

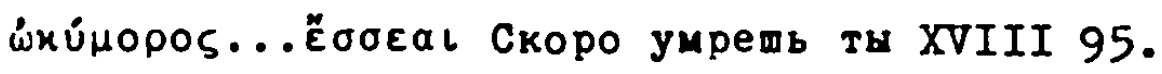
$\dot{\omega} x \cup-\pi \hat{\varepsilon} \tau{ }^{\prime}$ бурнолетахщи, vgl. Teil A; mit getrennten Gliedern бурно летами VIII 42.

Man könnte noch viele Beispiele für die Variationsfreudigkeit von Gnedič anführen. Die vorstehenden Beispiele stellen nur eine kleine Auswahl dar. 
2. Gnedið Vorliebe zum Variieren geht so weit, daß er ein griechisches Nominalkompositum nicht nur durch verschiedene NK oder sinnverwand te Simplicia bezw. $/$ lendungen übersetzt, sondern öfters ein NK oder Simplex durch ein Wort, das einen ganz anderen Sinn hat, ersetzt, wenn ihm dieses als Epitheton passend erscheint. VOß hillt sich dagegen viel getreuer an das Original.

Folgende Beispiele seien anfe führt:

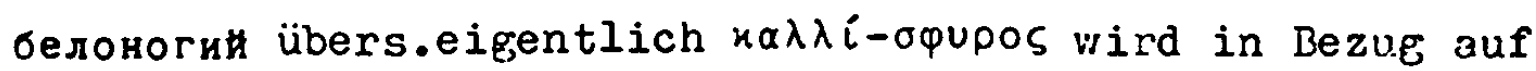
Theano dann auch für $x \alpha \lambda \lambda\llcorner-\pi \alpha$ p nos ver vendet (bei Voß "rosig");

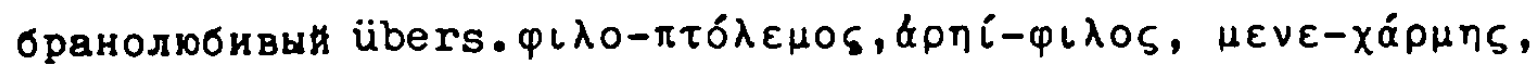
wird aber auch verviendet für $\mu \varepsilon \rho \circ \psi$ (VOß übers."vielfachredend");

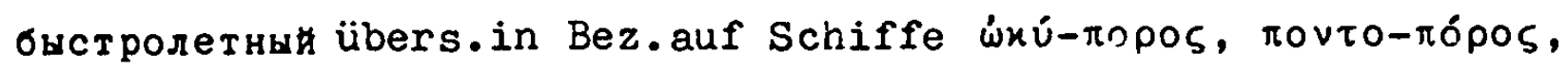
wird sinngemäß verwendet für $\dot{\omega} x u ́ s$, foós aber auch für $\gamma \lambda \alpha \varphi v-$

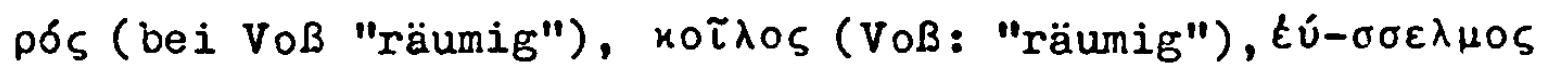

(VOB: "schöngebordet");

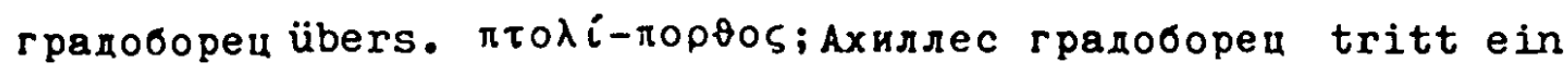

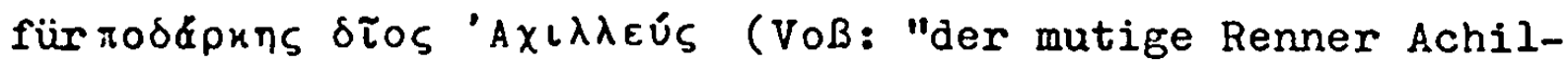

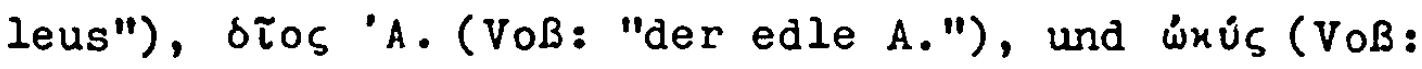
"schnell");

долгогривын übers. $\varkappa \alpha \lambda \lambda i-\vartheta \rho \iota \xi, \ell \dot{u}-\vartheta \rho \iota \xi ;$ tritt in Bez.auf Pferde auch ein für úxús (Voß: "hurtig");

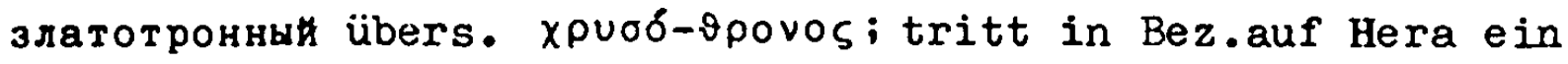
für $\lambda \varepsilon \cup и-\dot{\omega} \lambda \varepsilon \vee$ ○S (V०ß: "lilienarmig");

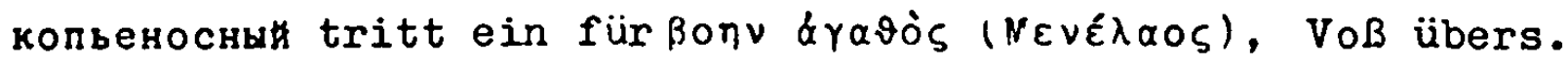
"der Rufer im Streit";

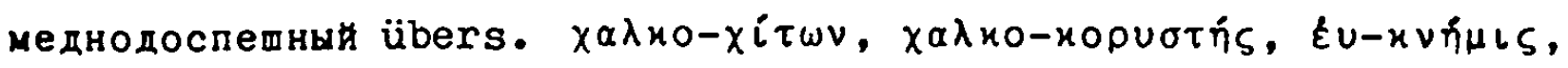

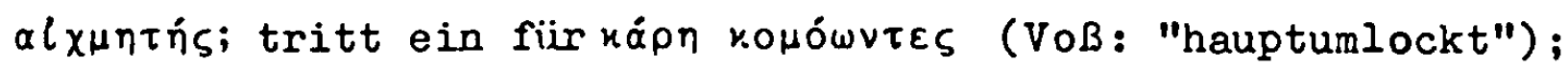
многопочтеннын ersetzt auf Thetis bezogentú-xоноs (VOB: "lockig");

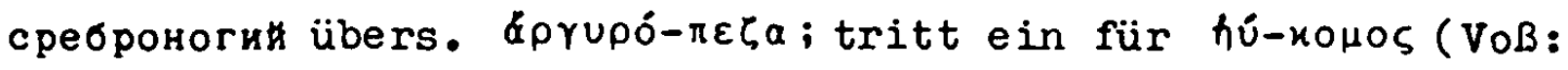
"lockig");

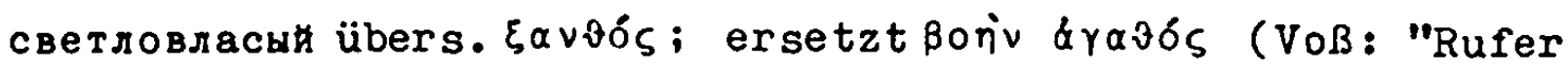
im Streit");

светлоокин übers. $\gamma \lambda \alpha \cup и-\tilde{\omega} \pi \iota s$; ersetzt $\measuredangle \gamma \varepsilon-\lambda \varepsilon i n$ (Vоß: "siegprangend"); 


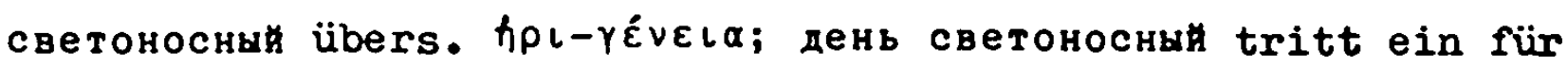

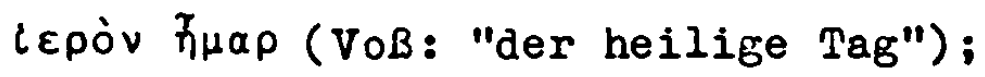

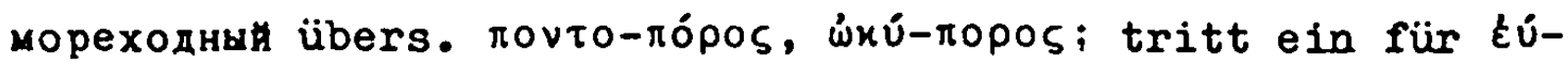

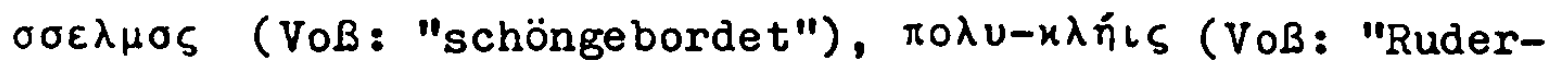
schiffe"), $\alpha \mu \varphi \iota-\varepsilon \lambda_{\iota} \sigma \sigma \alpha$ (VOß: "Kuderschiffe"), દíon (VOß:

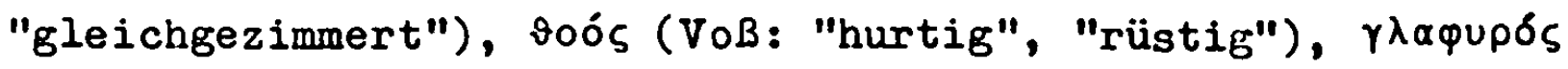
(

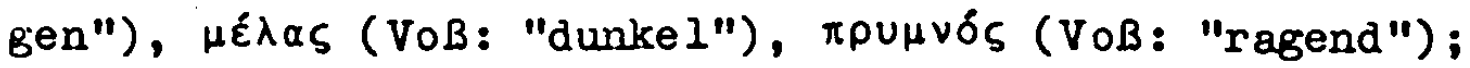

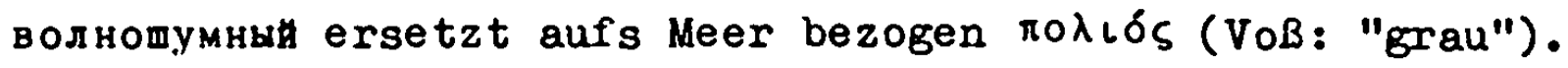
Besonders aufällig tritt die Neigung Gnedič, frei zu übersetzen oder sogar ein Wort ganz anderen Sinnes einzusetzen

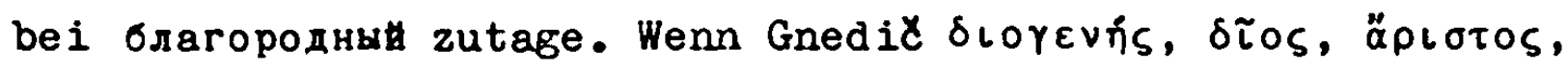

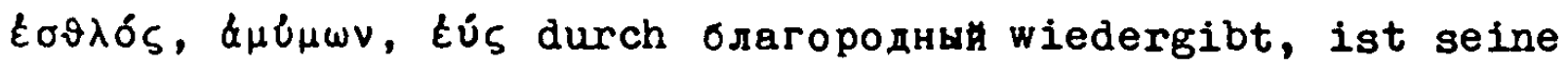
Ubersetzung sinngemäß, und auch Voß verwendet "edel". Bei den meisten in Teil A unter благородны aufgeführten Wörtern ist

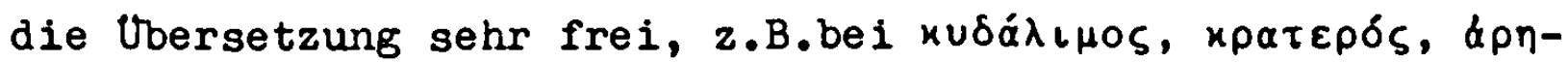

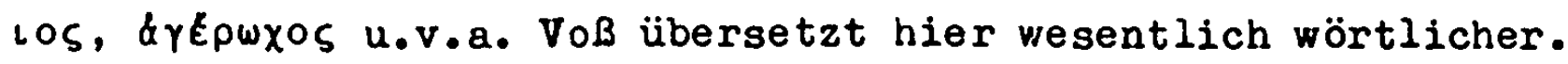
Nicht um tbersetzung, sondern um Ersatz handelt es sich bei

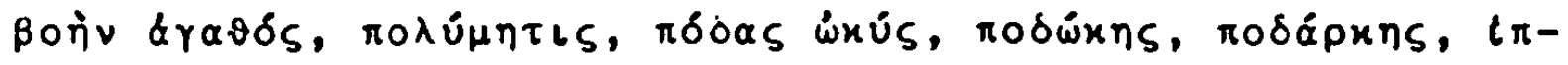

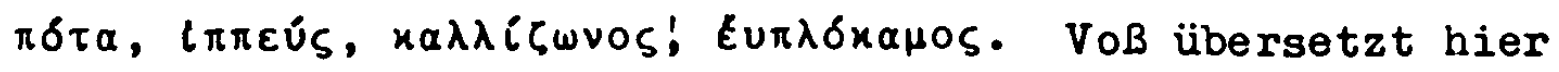
fast ausnahmslos wörtlich oder sinngemäß. Man gewinnt den Eindruck, als hätte sich Gnedil des Wortes благородны sо gern bedient, um bei berühmten Helden, vor allem bei Achilleus, aber auch bei Diomedes, Patroklus u.a. die edle Geburt

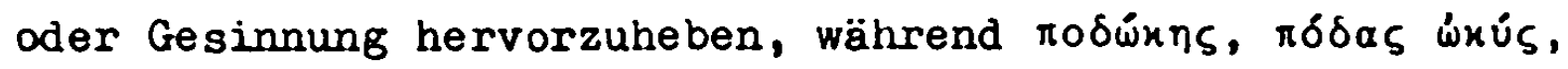
i $\pi \pi \varepsilon u ́ s$ usw. über die sittliche Haltung eines Helden nichts aussagen. 1)

Auch bei den Troerinnen scheint es Gnedic manchmal wichtiger gewesen $z u$ sein, daß sie von edler Geburt oder Gesinnung waren, als daß sie schöngegürtet oder wohlgelockt waren. Wenn umgekehrt GnediX in Bezug auf Achilleus $\delta$ ios oft durch быстроноги ersetzt, läßt sich das leicht dadurch erklären, daß die SchnellfüBigkeit das andere charakteristische Merkmal des Achilleus war; in der Ilias kommt oft die Wendung

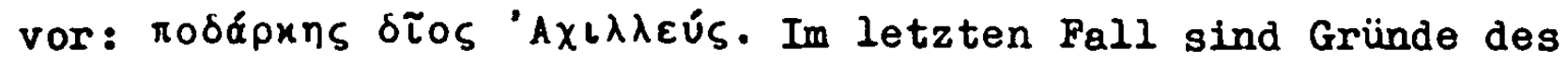
Versmaßes nicht maßgebend, da бдагородни und быстроногин

1.Vgl.Medvedeva a.a.0.S.34. 
gleiche Silbenzahl, gleichen Akzent und sogar fleichen Vokal in der Tonsilbe haben.

Sonst beeinflußte Gnedič sicher zuweilen Rücksicht auf das Versmaß bei der : Vahl des Ausdrucks, wie er übrigens selbst schreibt. Manchmal variiert er bei Homer stereotyp wiederkehrende Vlendungen auch, um den Leser nicht zu sehr zu ermüden. Wenn Gnedič NK miteinander vertauscht und überhaupt für heutige Begriffe relativ frei verfährt, kann ihm daraus kaum ein Vorwurf gemacht werden, denn man forderte damals vom Ubersetzer noch nicht die pedantische Genauigkeit, die heute bei der Ubertragung eines Textes der Antike für unerläßlich gilt. Gnedið selbst äußert sich zu seiner tbersetzungstechnik in seinem Briefwechsel mit Olenin ${ }^{1)}$ fol EendermaBen: "...по мнению моему тот переводчик мохет быть осухден за неточность, который к сумме слов подлинника прибавляет свои. Я, обнявши сумму слов гомеровских, ни одного прибавлять к ним не намерен, а для стиха заменяю иногда одно слово другим, у Гомера же находящимся. Таким образом, звуконо-

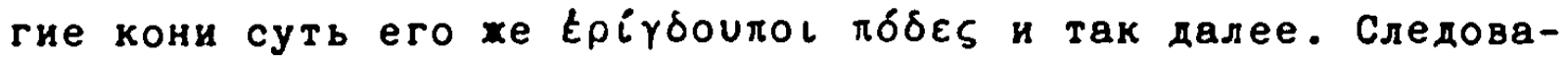
тельно, кто в переводе моем, взявии отдельно какой-нибудь эпитет или слово и не находя его соответственным, по-видимому, подлиннику в том стихе, из какого взято, будет осухдать меня в неточности - мохет ошибиться..."

Zur Ubersetzungstechnik von GnediC vgl. I.I.Tolstoj, GnediC kak perevodcik Iliady....Moskau-Leningrad 1935, S.103 ff, Kukulevic a.a.0.S.13 ff, Jegunov S.2'/1 ff.

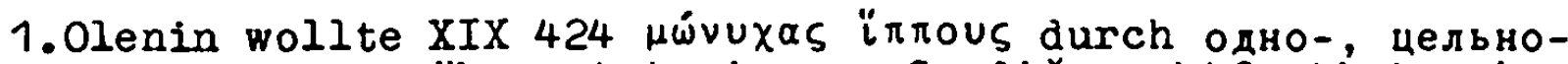
копытне кони übersetzt wissen. Gnedid rechtfertigt seine tbersetzung durch звуконогие кони, vgl. Kukulevič a. a.0.S.33, Jegunov S.193 ff. 
II. Wenn man die Nominalkomposita, die Gnedil in seiner Iliasübersetzung gebraucht, näher betrachtet, so lassen sich verschiedene Gruppen feststellen:

1. Gnedič verwendet ein NK, das schon vor ihm im Russischen oder Kirchenslavischen nachweisbar ist, und zwar

a) zur Ubersetzung eines NK bei Homer.

a) Dabei deckt sich das homerische Hort nur selten mit dem griechiscien Wort, das in den Wörterbüchern von Sreznevskij, Polikarpov oder Miklosich als Grundlage alter Lehnübersetzungen oder als Entsprechung alter russischer oder kirchenslavischer NK aufgeführt ist. Eine solche tbereinstimmung ist z.B.der Fall, wenn боговидны sowohl bei Homer als auch bei Polikarpov karpov

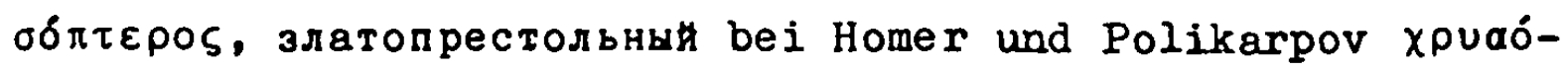

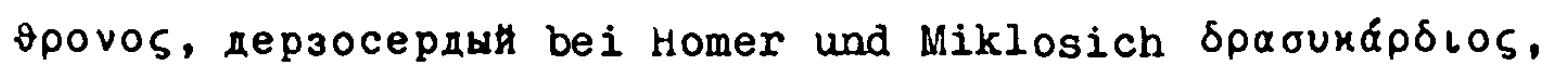

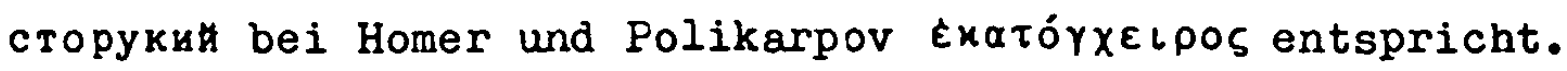

- $\beta$ ) In den meisten Fällen entspricht das homerische Wort nicht den Ausdrücken, die sich in den Wörterbüchern von Sreznevskij usw. finden, z.B.übersetzt Gnedič mit блаrодуш-

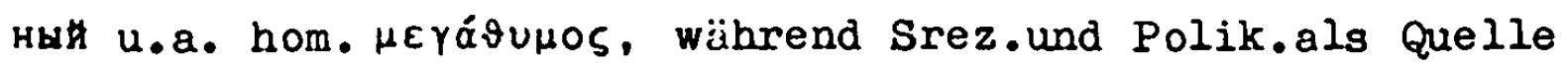

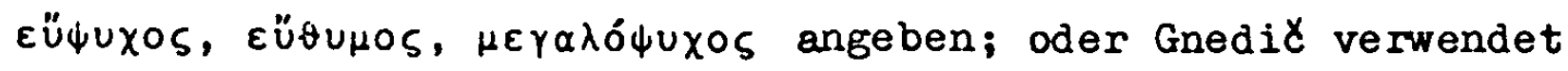
всеплоднын zur ibersetzung von

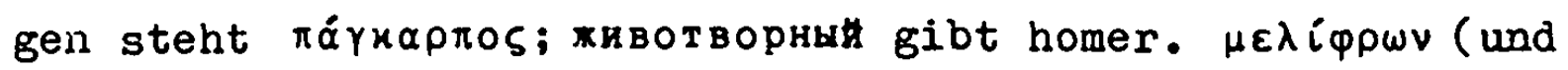

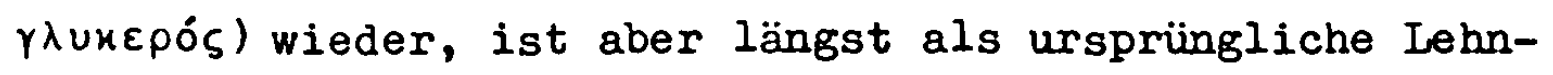

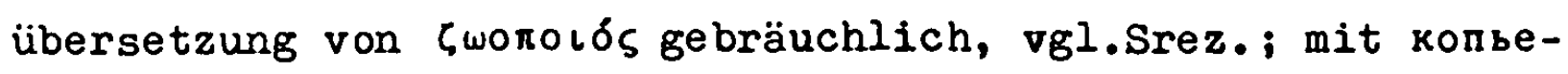

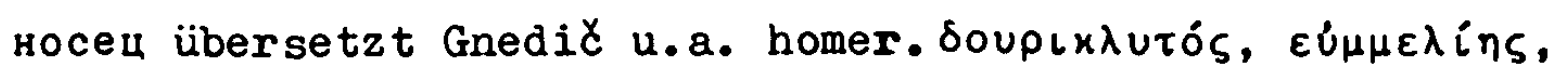

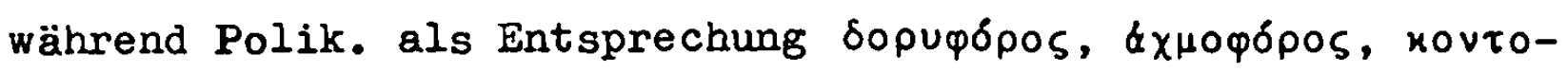

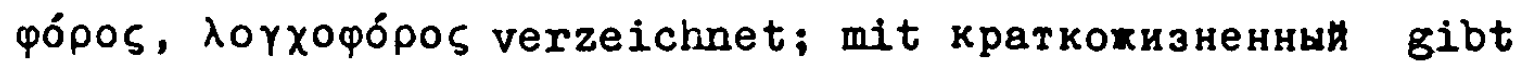

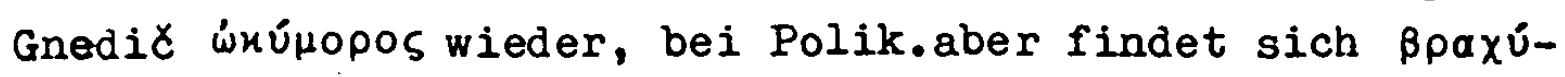

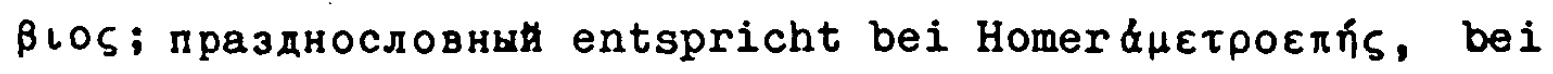

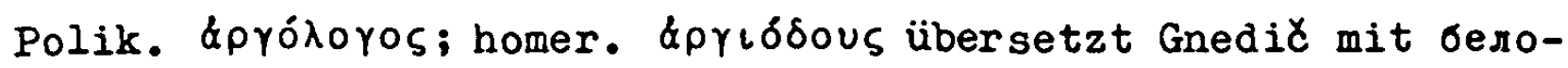
зубын, das Wort ist erst bei Nordstet und später bei Heym belegt; $\dot{\omega} x u ́ \pi \tau \varepsilon \rho \circ$ gibt GnediC mit быстрокрылы wieder, der Ausdruck ist im russ.Volkslied gebräuchlich, vgl.Sobolevskij; 
ebenso ist черногривы, womit Gnedič xuavoxaitns übersetzt, in der Volksdichtung beliebt, vgl.Sobolevskij und Golovackij.

b) Gnedic verwendet ein NK, das schon vor inm nachweisbar ist, zur thersetzung eines homer. Simplex, eines verbalen Ausdrucks, einer mehrgliedrigen Wendung. Nicht selten fügt er das Wort ohne Vorbild im griech. Text sinngemäB in seiner Ubersetzung ein.

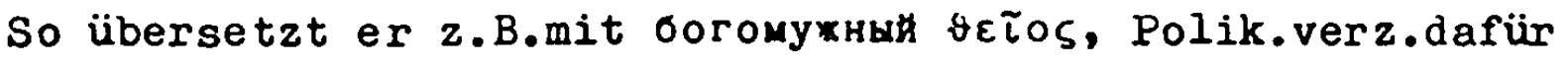

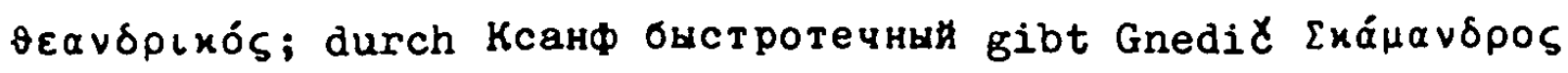

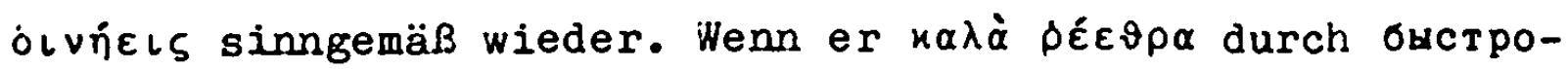
течные воды ӥbersetzt, verschiebt sich das Bild: das Substantiv воды und das Adjektiv бистротечные besagen zusammen dem

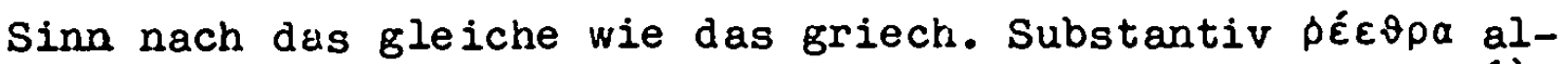

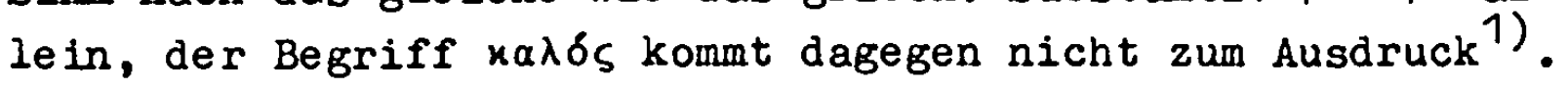

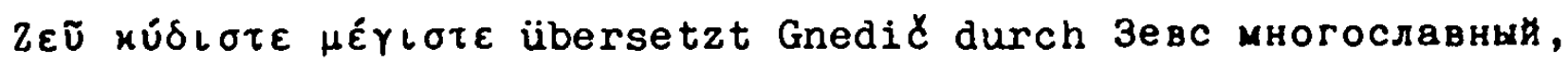
великин; hier wird die Funktion des Superlativs durch die Zusammensetzung mit Mного ausfedrückt. Ähnlich übermimmt das Kompositionsglied веле- die Funktion des Superlativs, wenn

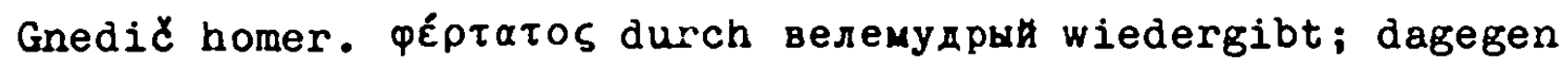
findet sich bei Sreznevskij als kintsprechung $\mu \varepsilon \gamma \alpha \lambda \delta \varphi \rho \omega v$. An anderer Stelle wird велемудрын als typisches Charakteristikum des Odysseus ohne intsprechung im griech. Original eingefügt. Ohne Änderung des Sinnes übersetzt lüngst ge-

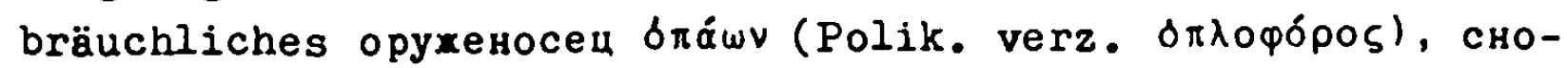

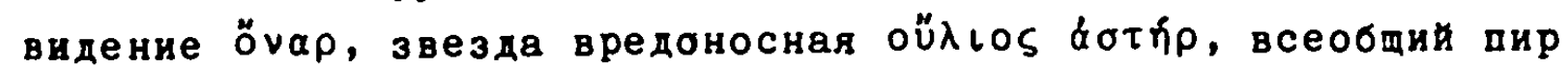

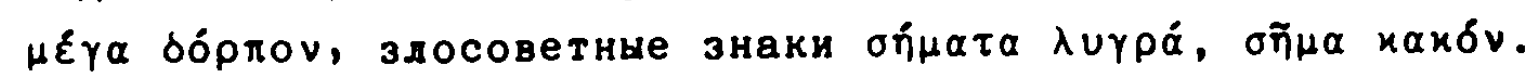
Frei, aber aus dem Zusammenhang erklärlich ist die tbers.von \&иท́р durch древодел: древа пронзает она (секира) под рукой

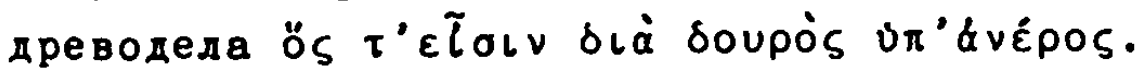

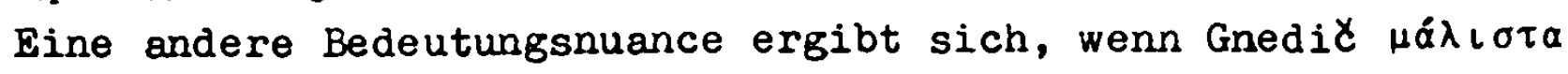

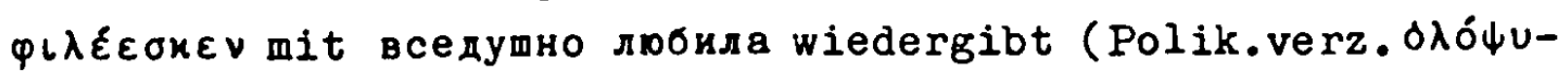

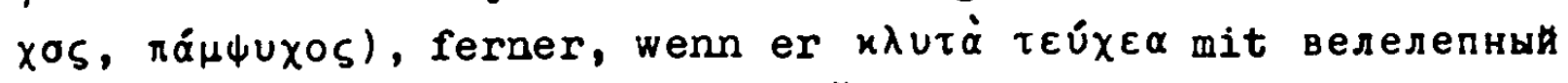

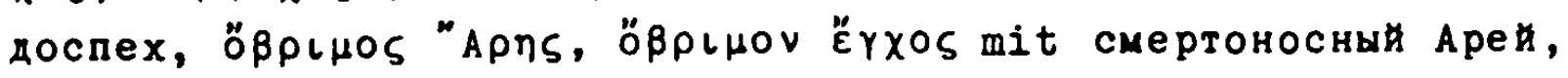

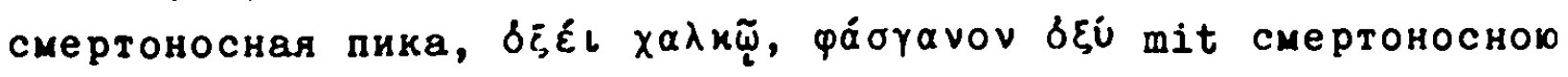
медью, нохом смертоносным übersetzt. GnediC legt also öfters,

1.VOB übersetzt "die schönen Gewässer". 
von seiner eigenen dichterischen Fhantasie verleitet, den Wörtern einen subjektiven Sinn bei, den sie im Original nicht haben, vgl. Tolstoj a.a.0.S.105.

Im Homertext steht ein syntaktisch anders aufgebauter Ausdruck. Als kleine Auswahl seien nur folgende Stellen angeführt:

(но) пушой доброхотная (вестница Зевса тебе я) übers. $\left(6 \lambda \lambda^{\prime}\right)$

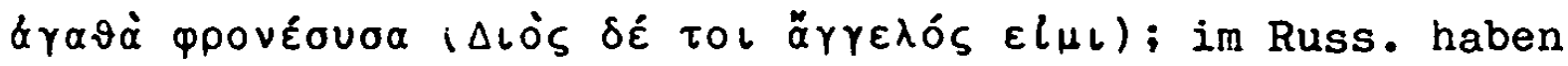
wir ein adjekt. Wh mit abh:̈njigem Instrumental der Beziehung, im Griech. ein Partizip Pr. mit abhängigem Akk. des inneren

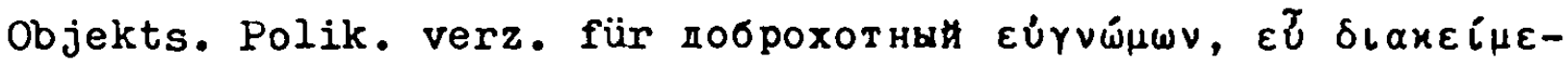

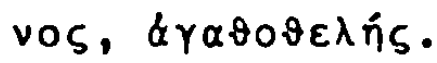

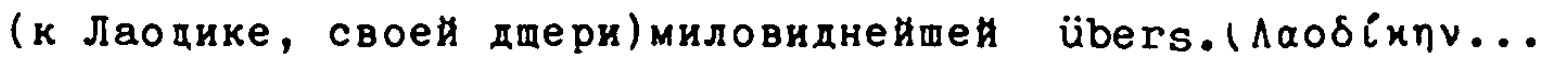

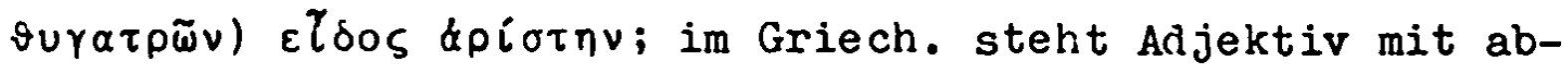
hüngigem Akk.der Beziehung.

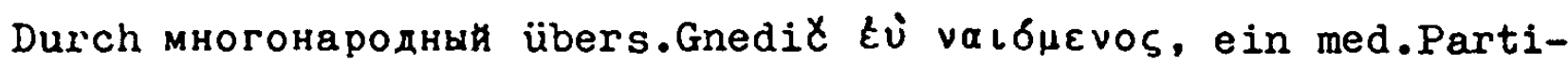
zip, das durch ein Adverb näher bestimmt ist;

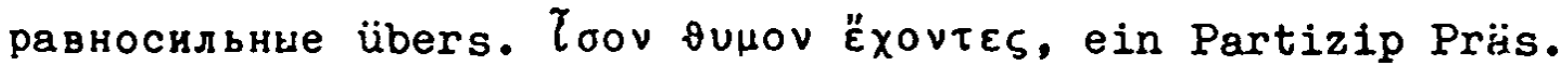
mit abhïngigem zweigliedrigem Akk.Objekt.

Das von einem Adjektiv abgeleitete Substantiv малодушие

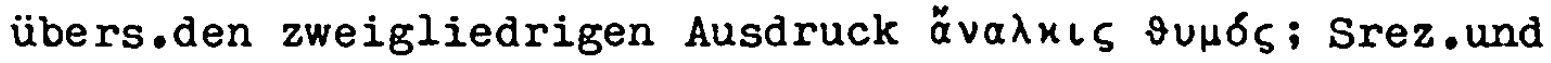
Polik. geben als Entsprechung für малодушие $6 \lambda \iota$ яофuхí bezw. $\mu \iota к \rho \circ \psi \cup \chi i \alpha$.

Там же Ге๘ест знамениты извил хоровод разновидный übers.દv

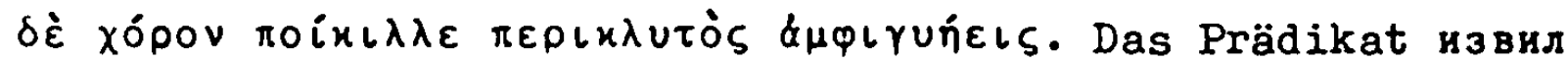
und das Adjektiv разновидның geben dem Sinn nach dasselbe

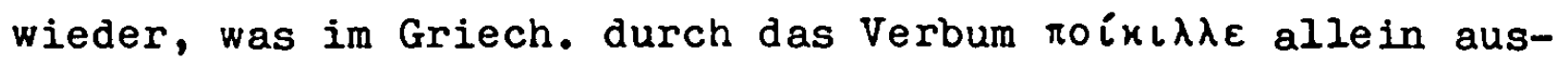
gedrückt wird.

(Словно когда водовод...) ров водотечный проводит ӥbers.

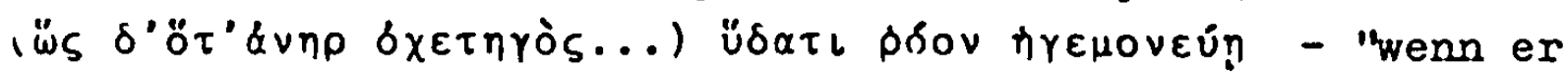
dem Wasser einen Graben zieht".

Ohne Entsprechung im Original sind eingefügt u.a.

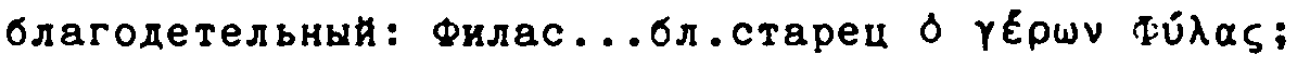

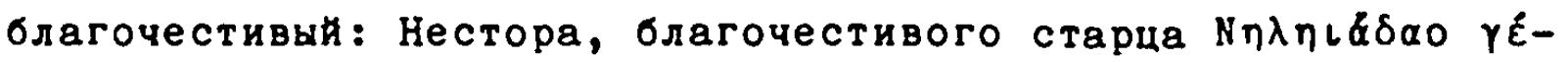
povтos;

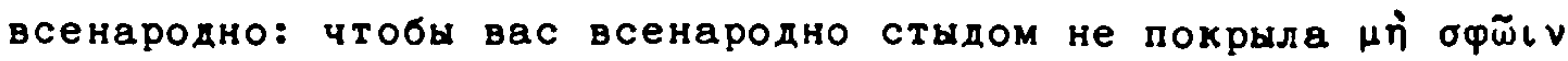

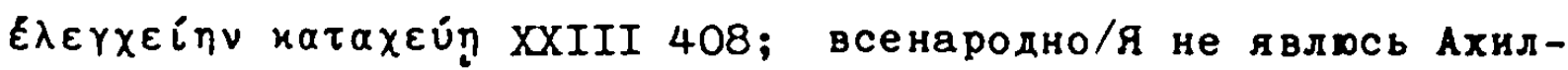

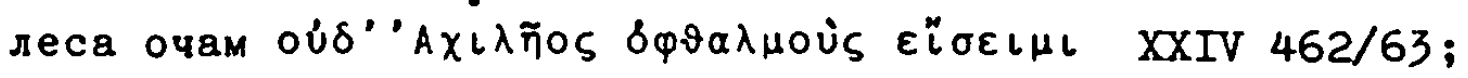




$$
-72-
$$

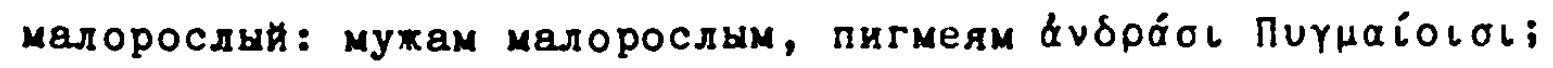
плотояднни: и самих распростер их в корысть плотоядным/ Пти-

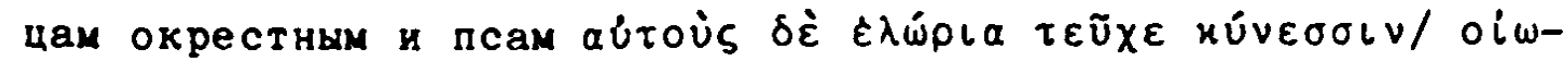
voน̃ $\tau \varepsilon \quad \delta \alpha \tilde{\tau} \tau$;

светозарнын: Солнца лучам светозарным они совершенно подоб-

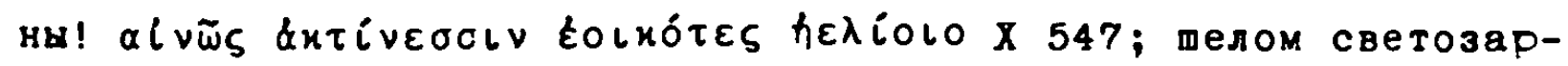

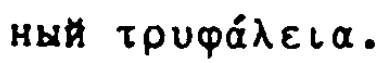

драгоценнын ist öfters eingefügt, z.В. Сына Менетия мы собе-

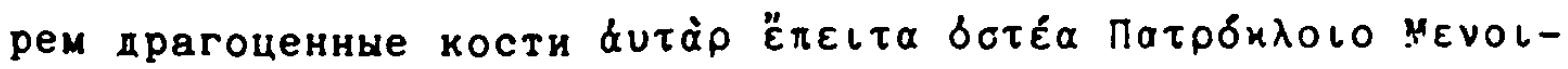

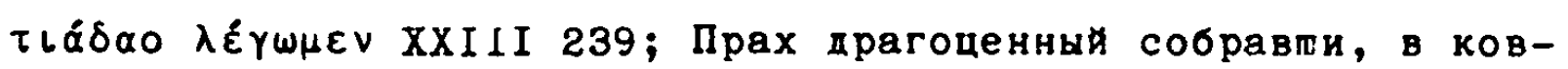

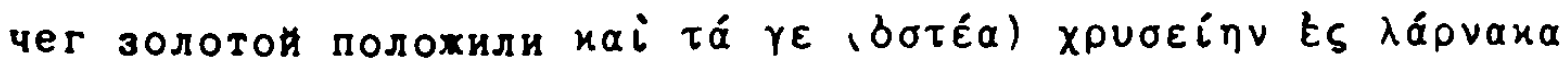

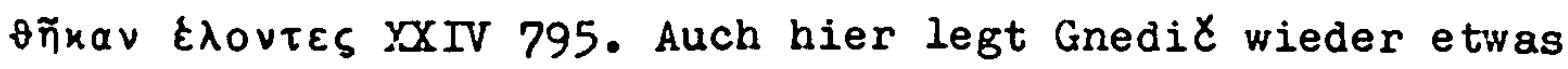
von seinen eigenen Empfindungen in seine Ubersetzung. Entsprechend der Tendenz Gnedid zum Variieren geben manche NK sowohl ein homerisches Kompositum als auch ein Simplex

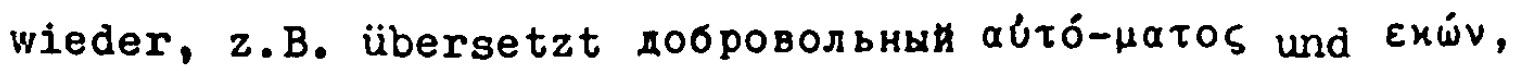

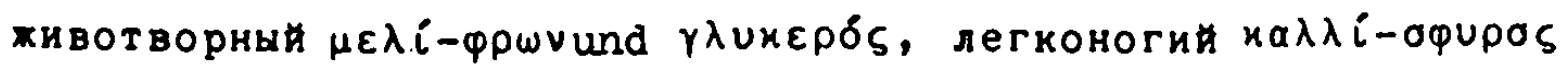
und íxús.

Für мореходның, смертоноснын U.v.a. vgl.Teil A. 
2. Gnedic schafft Neubildungen, und zwar

a) Lehnübersetzungen nach dem Vorbild homerischer NK. Dabei lassen sich verschiedene Stufen der Genauigkeit unterscheiden.

a) Beide Glieder des Kompositums sind wörtlich übersetzt,

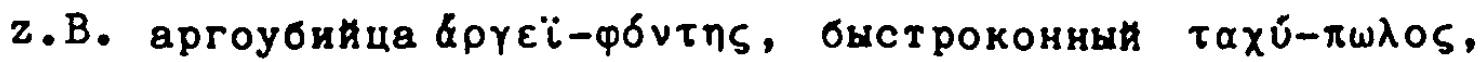

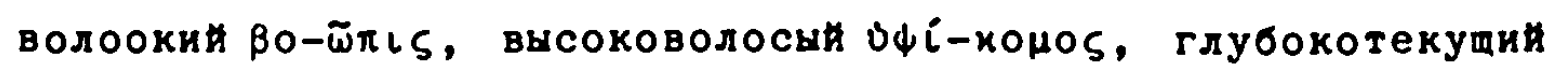
$\beta \alpha \vartheta \dot{v-\rho \rho о о ́ \varsigma, ~ д о л г о в н и ̆ н ы ~}$

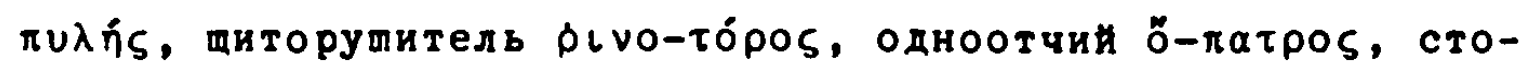

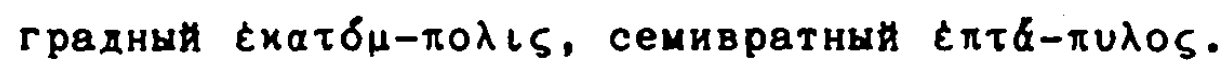

B)Ein Glied des Kompositums ist wörtlich, das andere frei übersetzt.

Das 1.Glied ist wörtlich übersetzt z.B. in вечнохивучин,

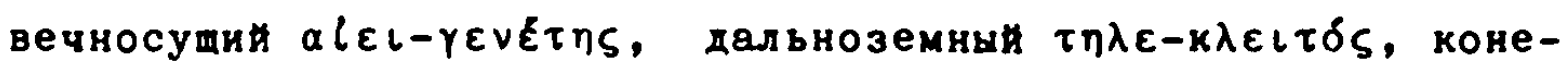

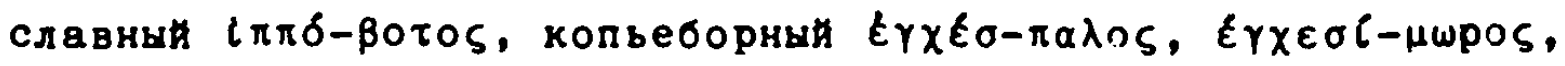

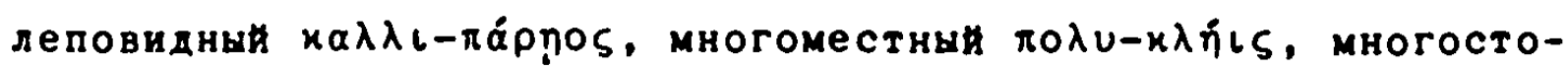

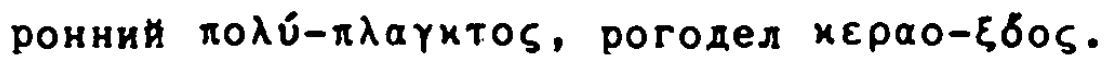

Das 2.Glied ist wörtlich übersetzt z.B. in бистроскакучин

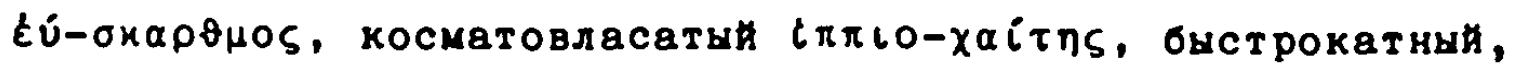
легкоквтнн $\varepsilon \dot{-\tau \rho о \chi о S, ~ д л и н н о о д е х н ы ~} \varepsilon \lambda и \varepsilon \sigma i-\pi \varepsilon \pi \lambda \circ \varsigma$, немолчно-

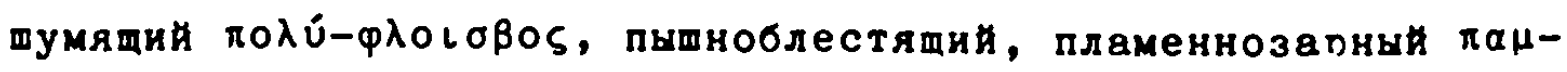
фavówv.

r)Gelegentlich sind beide Glieder frei, aber sinngemäß über-

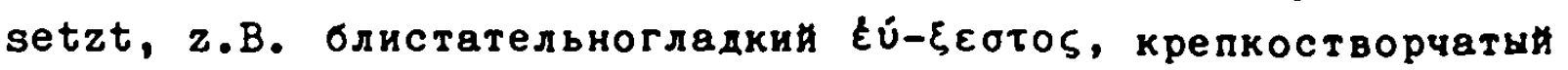

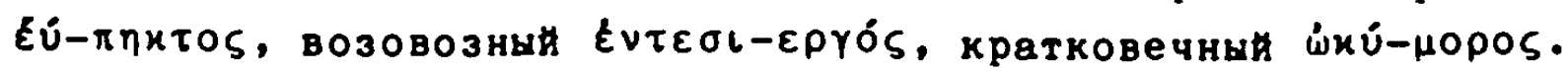

6) Als Iehnübersetzungen sind ferner die Fïlle aufzufassen, wo im griech. Original zwar kein NK steht, wohl aber ein zweigliedriger Ausdruck, der sinngemäß einer Zusammensetzung nahekommt, so daB eine tbersetzung durch ein NK naheliegt.

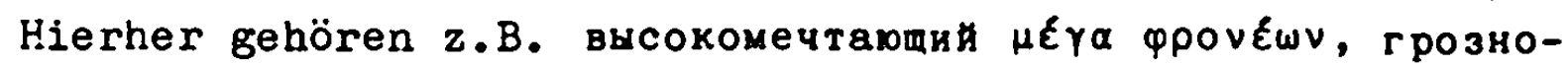

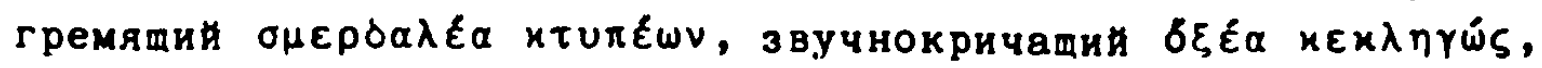

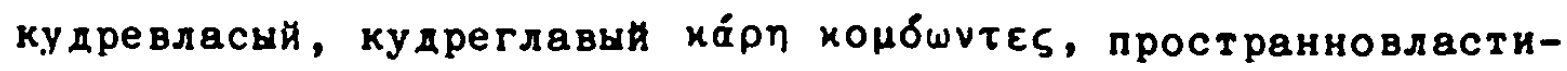

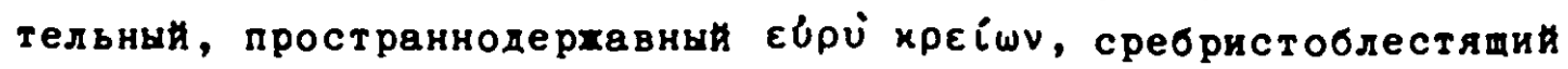
\&prìs paeıvós. 
Für folgende NK konnte d.Verf.keine älteren Belege finden, die meisten von ihnen sind also wohl von Gnedið geprägte Lehnübersetzungen: 1 )

aproубинца

багрянозлатистын

безумноречивын

белокликин

белорунны

беспояснодоспетнын

благодумный

благозданнын

блистательногладкин

блистательнооки

боговещин

браздоде ржец

б ранодушнын

б рано дитащи

бранольбивый

бурнолетаюи

быст рокатнын

быст роконны

быст рольршинся

быст роокин

быстроскакучи

ветроногин

вечноживущи

вечносушин

Возовознын

волоокин

всевещи

всеобъемныи всеувлекающй

высокове ршинный

высоковолосый

высоковоротнын

высококрутящинся

высокопрестольнын

высокотвердыннын

высокоходя шин

высокоцаря тин

высокочу бастын

Глубодоннын

Глубокопучиннын

глубокотекушин

гордовынни

горожитель

громовержущий

громодертец

густогривын

густокамыш ный

давнородши ися

дальновержец

дальноземец

дальноземныи

дальнометки

дальномечущин

двадцат идвухмерныи

двое дон нин

двулезвенныи

1.Natürlich kommen nur die Fälle in Betracht, die in Teil A als griech. Entsprechungen ein NK zeigen und an erster Stelle aufgefüht sind. Браздодерxец ist also z. B. ther-

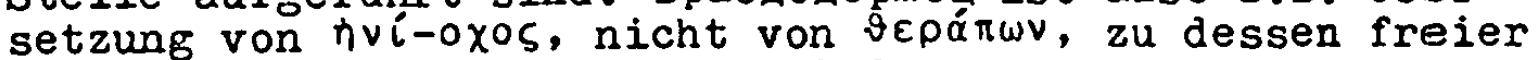
Wiedergabe es aber vermendet wird.

Die NK, bei denen trotz Fenlens ölterer Belege die Urheberschaft von Gnedid fraglich erscheint, wurden mit Fragezeichen versehen. 
двуост рьй

двускладнын

двусторонны ?

двуя ремның

дебелокопытның

девятигодово

девятилоктево

дерзословны

длинноОдехны

длиннотенны

длиннохитонны

доб роснастны

добычельбивы

долговыниы

долгохалый

долголезвенны

древлерохденный

древорубнын

ду шесне дный

дыроокия

звонкогласы , -голосы

з вуконоги

земледерхатель

златобразды

здатолукин

златомечный

златострелы

златотроннын

конеборец

конеборнын

коневласы

конеславный

коннодоспешнын

копьеборец

копьеборны

косматовласатын

красивоколеснын

красивоотесанны красивоплетенын

красивопонохнын

красноносн

красноопоясанны

кратковечнын

крепкобатеннын

крепковратны

крепкомедны

кंрепкоснастны

крепкостворчаты

крепкостенны

крепкочелы

криволуки

круговратнын

кругозарнын

крутовынй

легкокатны

легкометны

леповидны ?

лепогривын

лепокормнын

лепокудрын ?

лепотронны

лесисто-холмистын

лхелюбец

лиленнораменны

луконосец

лодоубинца

медноб ронны

медноголосын

медно-, медянодоспешнын

меднохалын, -хальнын

меднозданны

медноконечни

медноланитнын

меднолатнын

медноногин

медноо рухный 


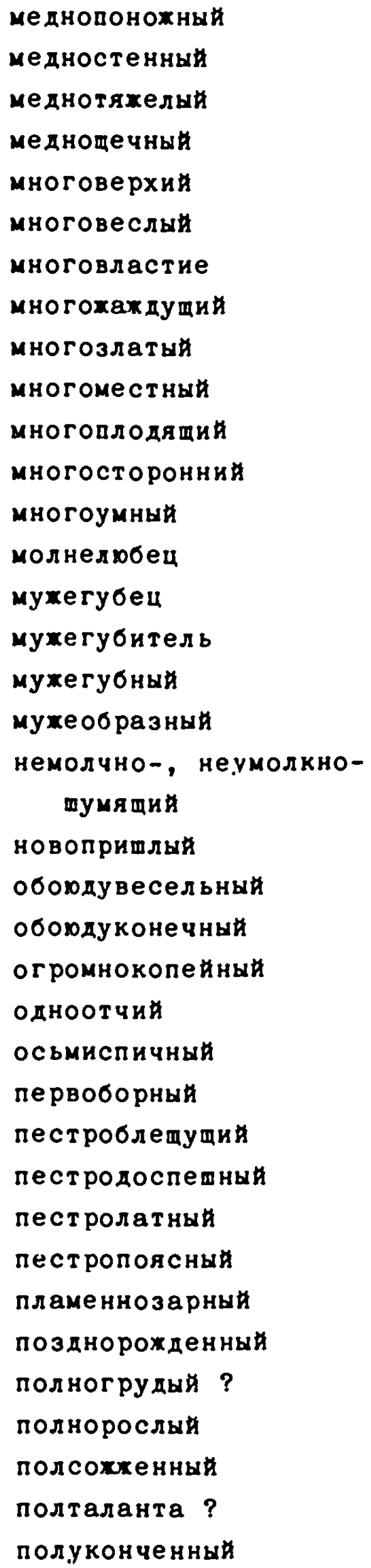

прекрасновенчанныи

прекрасновласый, -волосы

прекрасноланитын

прекрасносоставленнын

п рост ранног ремящи

прямокормный

прямолетны

псообразнын

птицегадатель

пышноблестящи

пьшноволосый

пышногривын

пышноз даннын

пышноОдехның

пышнопонохны

пышноризыи

กแтносияющи

пытност рудны

пышноузорныи

пятизубец

разноземный

рогодел

роскошноволосыи

рукоборец

pyкопаmец

румяноланиты

руноносный

светловодный

светлоокий

семивратныи

семикохныи

семистопнын

сердиеглохущи

сребристо-, серебристопучинныи

сребро-, серебряногвоздныи

среб ролуки

среб ромолненны 
стоградны

стоскамейны

стоступенны

стотельчие, -тельчия

стреловерхец

ст релолюби вы

ст релометнын

твердокопытный

тихокатяшияся

т реконечны

т репетолистнын

т роехал ьны

тучеводец

тучегонитель

тяжконоги

Фимиамогадатель

хит ротканны

хит роумный

хит ротвенныи

черноводны

черноголовн ? черноносы

чернооблачны

чернотучны

четверо-, четыребляшнын

четыреколесны

четыреслоһны

чухелюдны

шестигодово ?

ши роковорот нын

ширококрылаты

широкоразливны

пирокоразметныя

широкотекушин

широкочелистын

шлемоблещушия

щедропит ающи

шиторушитель

яркоблестяши

ясновещи й

ясноречны

b) Gnedid schafft Neubildungen, aber nicht als Lehnübersetzungen, denn bei Homer steht an der entsprechenden Stelle kein IVK, sondern

a) ein Simplex, z.B. übersetzt багрянозлатисты фогу

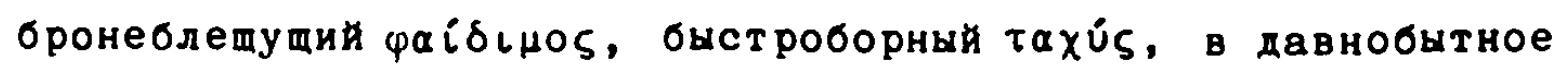

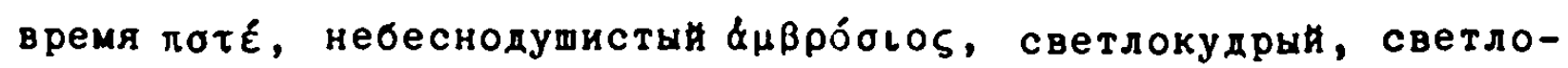

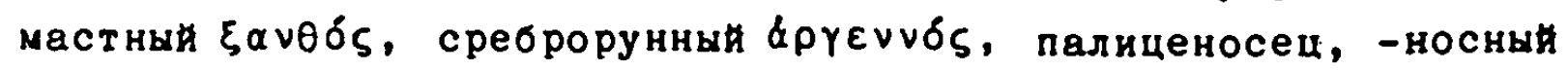

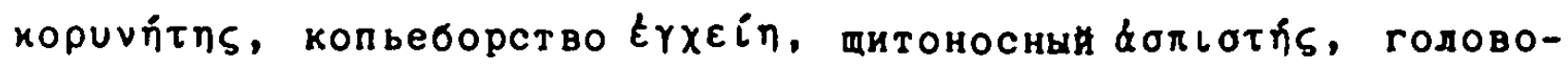

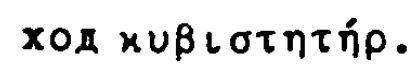

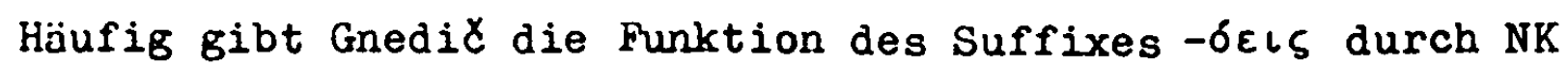

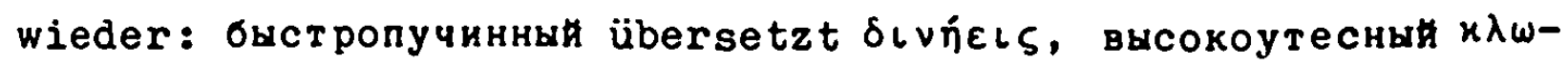

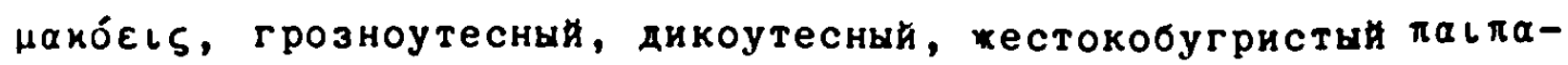
$\lambda$

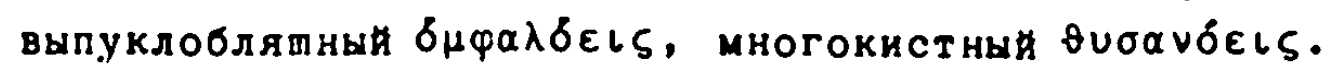


Zu dieser Gruppe gehören:

багрянозлатисты

бронеблещущи

быстроборный

быст роскачущи

волношумны

волокохный

выпуклобляшный

выпуклосветлы

высоковздымавпйся

глубобраздны

головоход

густопорости

густорунны

давнобытный

дуговерхин

Звонкорокочущй

златоблещущия

копье борство

крепкобронны

крепко (co) зданны

криворогия ?

кру тоносын:

легкодвикимы

малосмысленны

мухеубйст венны мучительноост рый

небеснодушисты

палиценосец, -носный

петеборны

п раз дноб ро дны

путеводец

ратоводец

светловласый

светлокудрын

светломастный

светлосияющи

скипт роносный

с реб роковныи

сребропламенныи

среброрунны

страстноблестяпи

твердобронны

хит роизмыпленны

ху дожносработанный

чернобоки

чухелюдны

широкопапу пий

пирокоуст роеннын

щитоносный

B) Ofters gestaltet GnediC eine Vendung, die bei Homer einen anderen syntaktischen Aufbau aufweist, zum NK um oder gibt einem Bild eine andere Fürbung, z.B.übersetzt быстронесуши-

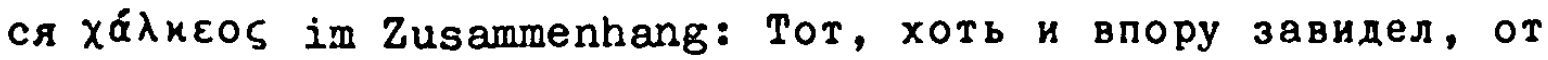

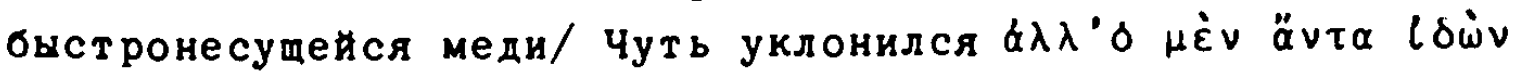

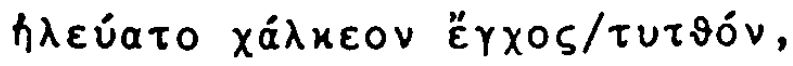

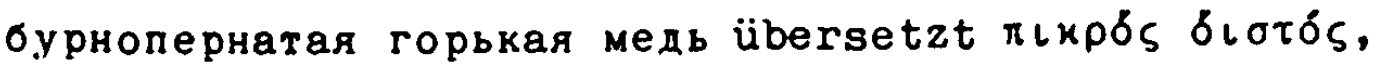
Голосом грознопретительным (Феб стреловержец воскликнул)

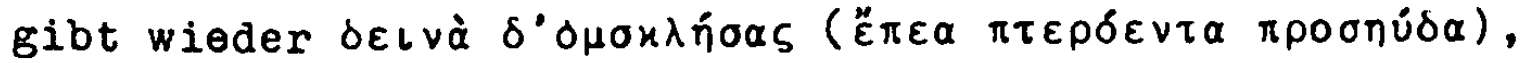

1.Sehr freie Ubersetzung von roגıós. 
но копьеметец отличный меж гелленов всех и данаев ӥbersetzt

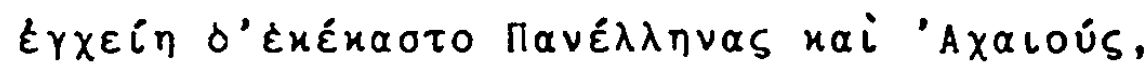
молнезержец steht für $2 \varepsilon \tilde{S}$,

птииегданье übersetzt kein neutrales Verbalsubstantiv, sondern der russ. Wendung и славного в птицегаданьи Эннома entspricht kai "Evvopov olwvlctív. Hierner gehören ferner:

огромновысокий

пышноструистын

родоначальница

\author{
свирепогордящйся \\ стрелобойны \\ шестимернын
}

Y)Nicht selten fügt Gnedið ein von ihm geprägtes NK sinngemäß ein, ohne daß ein entsprechendes Wort im Original steht. Diese Einschübe haben offenbar das Ziel, eine bestimmte Eigenschaft einer Person oder eines Tieres oder ein charakteristisches Merkmal eines Gegenstandes hervorzuheben, vgl. Teil B II 1 b.

So ist eingeschoben:

быстрорытущи веi пес

дерзкоотважный bei менетиев сын

ллиннокудрый bеi Аполлон

конеборственны беi трояне

копьеноснын bei Полипет (Polypoites)

медноблешущий bei шина als tbersetzung von $\varepsilon \pi i$ боштроv

многобляшистый, -бляшный bei тит, шлем

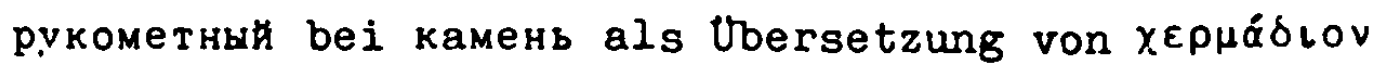

седовласын bei Нестор

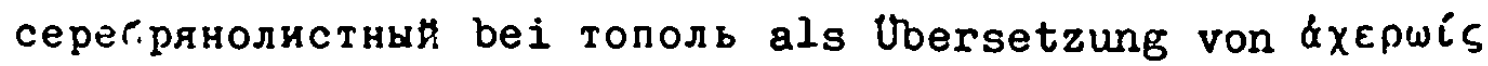
темночелын bei вол

усердносоветнын беi брат

черноглавын bei вал

ясноокин bei Ađина.

c) Die Neuerung von Gnedil beruht manchmal nur darauf, daß er ein schon vor inm gebrüuchliches NK mit einem anderen Suffix verwendet oder eine der beiden Komponenten durch eine etymologische Dublette oder ein Synonym ersetzt. Die Belege für das Vorbild finden sich in Teil A unter dem ent- 
sprechenden Vort angeführt. So bildet er:

браноносец $\mathrm{zu}$ браноносны

лжелюбец $\mathrm{zu}$ лжелюбивын

рукопашец zu рукопашны

земдедержатель zu земледержец

громодержец zи громолержатель, -держитель

путеводец zu путеводитель, -вождь

родоначальница $2 u$ родоначальник

бранолюбивы zu бранолюбец

стрелолюбивы zu стрелолюбец

копьеносны 2 копьеносец

скиптроносни zи скиптроносец

первоборныи zu nервобореи, analog dem Nebeneinander vor

светоносец und светоноснын

стрелометны zи стрелометатель, -метница

громовержущи $z и$ громовержец

р.укомонны zu рукомонник

златострелы zu златострельныи

ясноречны $\mathrm{zu}$ ясноречивы

высоковершинный $\mathrm{zu}$ высоковерхия

стотельчи zu стотельны

волнотумны 2 волнотумящи

быстролетящи $\mathrm{zu}$ быстролетный

легкодвихимы $\mathrm{zU}$ легкодвижның

боговещи zu боговещанный, -ветатель

всевещй $2 u$ всеведыи, -ведучий

древлерохденны zи древлерождение

мужеубинственны $2 и$ мужеубинство

многоумный zu многоумие, -уметель und многоразумный

пространновластительны zu пространновластвуяй, -владекщи

высокоцарями von высокоцарить zu -царствовать

дерзословны zи дерзословить

одноборец zи единоборец

गзоедонны 2 двудонны

четыреколесны 2 четвероколесны

шестигодово $2 u$ шестилетния

преворубны zи дроворубный, analog dem Nebeneinander von

дровосек und древосек. 
j. Fragliche Urheberschaft bei einigen Komposita

Es ist damit zu rechnen, daß das eine oder andere der in $B$ II $2 a, b$ angeführten Wörter, für die d.Verf. keine älteren Belege nachweisen konnte, doch schon vor Gnedic existierte. Durch spatere Untersuchungen aufgrund Jetzt nicht zugänglichen Materials mögen einige NK aus der Liste der Neuschöpfungen Gnedic zu streichen sein.

Es ist auch fraglich, ob Gnedid in allen in B II 2c aufgeführten Fällen tatsïchlich vom früher belegten Vorbild boeinfluBt war. Man muß vielmehr damit rechnen, daB er manche dieser NK selbstïndig geprägt hat.

Weiterhin ist nicht mit sicherheit festzustellen, ob Gnedic bei der Wahl bezw. Bildung von коневласын und молнелюбец durch die von Popov gebrauchten NK коневласвты und молнелюбивы beeinfluBt war oder umgekehrt. Da Gnedic und Popor Zeitgenossen waren und gleichzeitig Homer übersetzten, können sie die NK auch unabhïngig voneinander gebildet haben. Zweifelhaft ist ferner, ob Gnedic медноблешушин und многовесльн nach den von Kondratovid geschaffenen медноблистательны und многовесельнын gebildet hat. Da die Iliasübersetzung des letzteren nur handschriftlich vorlag, ist nicht nachzuweisen, ob Gnedic sie gekannt hat. Aus dem gleichen Grund ist es möglich, daß er poзоперстын und высокогремянин unabhängig von Kondratovil geprïgt hat.

Einibe $N K$ finden sich in der gleichen Form auch bei Zeitgenossen von Gnedic: Popov verwendet gleichfalls cpeбporвозднын und медноброннын, Martynov in seiner Iliasübersetzung (1823-25) меднолвнитнын und глиннотенныи. 1) Es ist müвig, darüber zu streiten, wer diese NK zuerst geprägt hat. Als

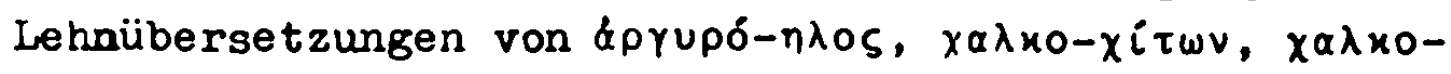

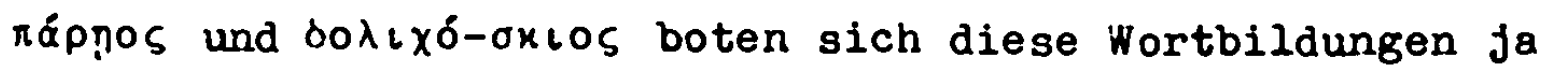
geradezu an. Zudem hat Gnedic die Ubersetzung von Martynov vermutlich nicht gekannt. 2) Ferner findet sich тучегонитель bеi Krylov in Богач и Позт (zwiscien 1821 und 1823), тиховенни

1.Vgl.Jegunov $\mathrm{S.325.}$

2.Vgl.Jegunov $\mathrm{S} .330$. 
bei Batjuskov in Мои пенаты (1811-12), пышноволосыи bei Del'vig in Конед золотого века (1828). Vienn diese ijerke auch ziemlich genau datierbar sind, so ist damit noch nicht jesagt, wie lang die $N K$ schon in der Phantasie der Dichter bestanden haben, bevor sie zu Papier gebracht wurden. I'an kann also nicht mit Sicherheit feststelien, wem das Urheberrecht an den Ausdrücken gebührt. 
4. EinfluB von $\mathrm{V} O B$

In der llahl bezw. Bildung einiger NK dürfte Gnedid von VoB beeinfluBt sein, dessen Homerübersetzung er, wie er im Vorwort $z u$ seiner eigenen tbertragung der Ilias schreibt, kannte und schiitzte.

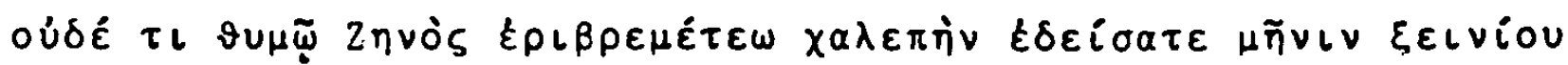
übersetzt VOB: und (wie ihr) nicrt geachtet Zeus' schwertreffenden Zorn, des Donnerers, welcher das Gastrecht beiiiget, Gnedil: Ни грозного гнева Вы не страшились гремящего Зевса; но гостеприимства Он покровитель.

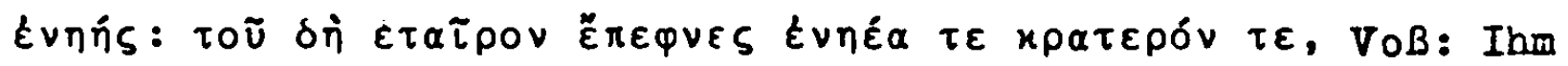
den Genossen erschlugst du, so sanftgesinnt und so tapfer, Gnedil: Ты умертвил у него кроткодушного храброго друга.

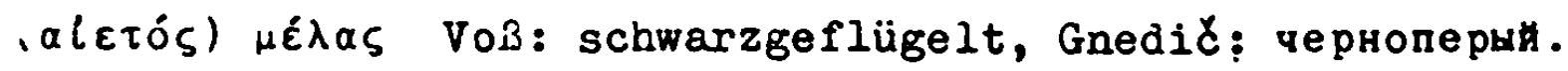

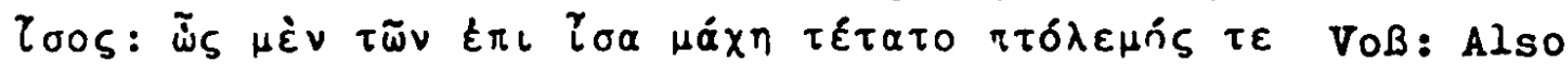
stand gleichschwebend die Schlacht der kämpfenden Völker, Gnedil: Так равновесно стояла и брань и срахение воинств. \&рүعчvós VOB: weißwollig, Gnedic: белоруннын.

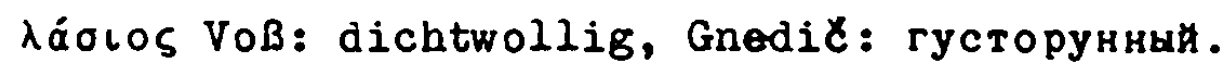

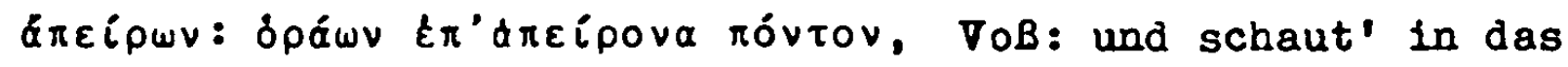
finstre Gewässer, Gnedid: взирая на понт темноводний.

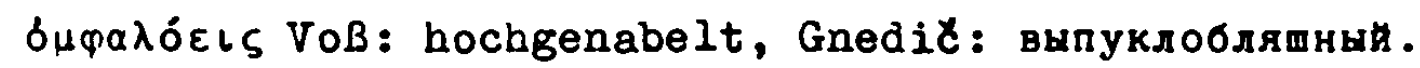

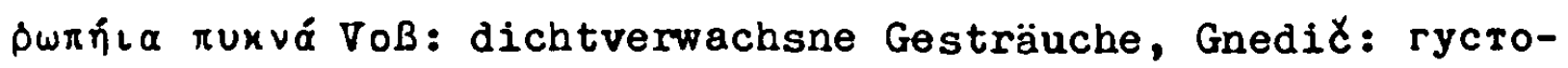
поросший кустарник.

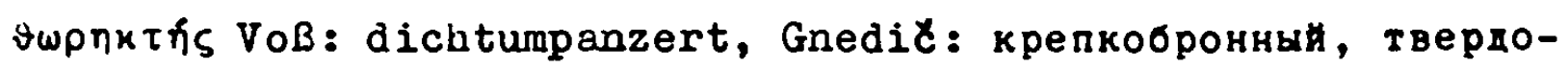
броннаи.

$\lambda \varepsilon \cup x \dot{\lambda} \varepsilon$ vos VOB: lilienarmig, GnediC: лилейнораменның.

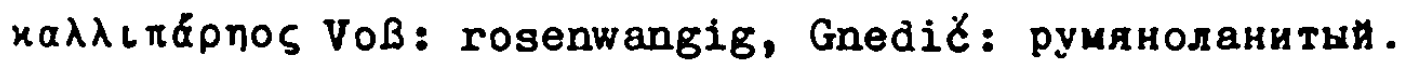

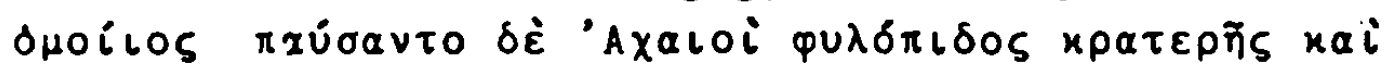

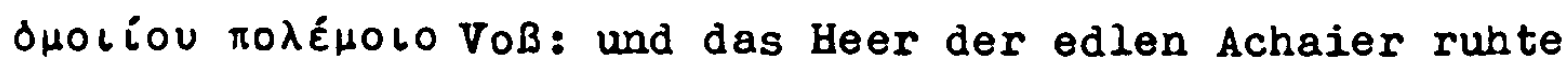
vom schrecklichen Kampf und allverderbendem Kriege, Gnedil: и рать благородных данаев Вся от тревоги и общегубительнои брани почила.

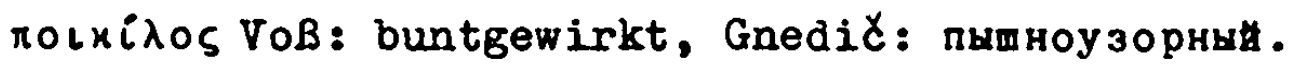

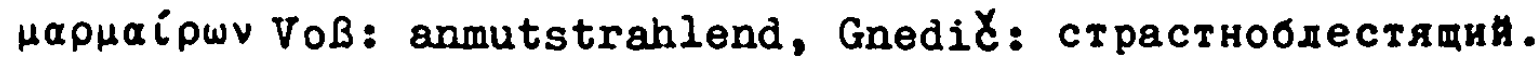

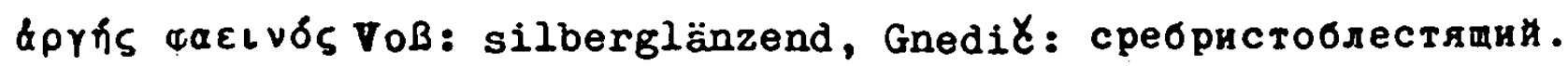




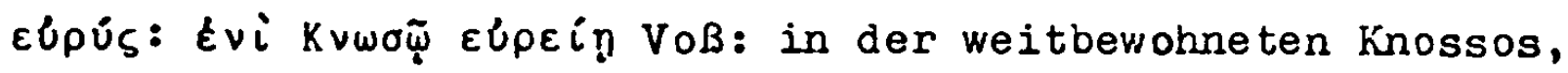
Gnedil: в щирокоустроенном Кноссе. $\chi \varepsilon \rho \mu \alpha ́ \delta\llcorner$ Voß: ein Feldstein, fausterfüllend, Gnedid: камень рукометныम.

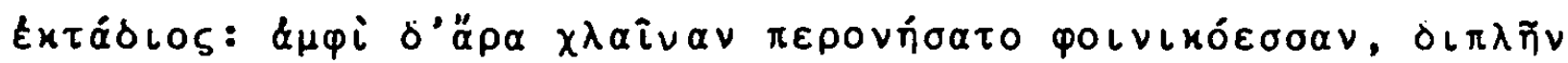

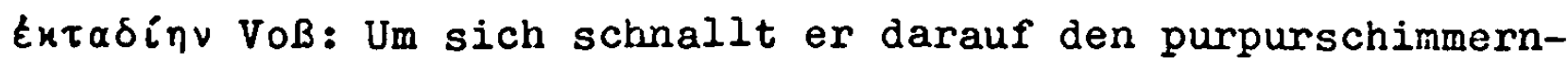
den Niantel, doppelt und weit gefaltet, Gnedic: После - кругом застегнул он двойно свой, широкопадуций, Пурпурный плащ. $\pi \varepsilon \lambda_{\varepsilon x \cup S}$ Voß: zweischneidige Axt, doppelte Axt, GnediC: ronop двуострыи, секира двуострая.

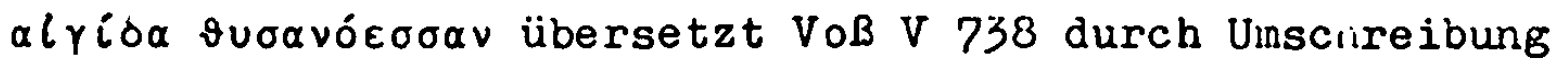
"die Ägis prangend mit Quästen", Grsedič: эгид бахромою косматыम, dagegen übersetzt VOß XXI 400 "quastumbordet", Gnedic: многокистннम.

XVI 703 schiebt Voß bei ratroklus sinngemüß "kühn", Gnedic дерзкоотвакнын ein, vgl. B II 2 b $\gamma$.

Besonders auffällig ist die Ubereinstimmung in der Ubers.von фoגxós, das "krummbeinig, säbelbeinig" bedeutet, durch

"schielend" bei Voß, косогласыи bei Gnedic.

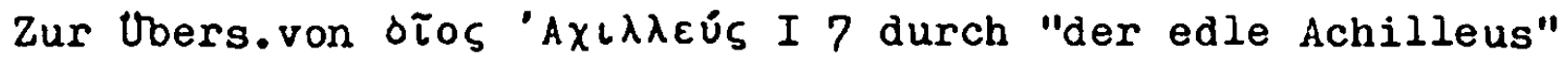
bei Vоß, герой Ахиллес благородны bei Gnedi丈 vgl. Kukulevi a.a.0.S.9 f. 
III. Art der Komposition

Substantiva

Außer einigen abgeleiteten Neutra (копьекорство, многовластие, птицегаданье, стотельчие) bildet Gnedid an Substantiven fast nur nomina agentis, die bis auf родоначальница sämtlich isaskulina sind, und zwar mit regierendem SchlußGlied. Äußerst selten prägt er Substantiva, deren zweites Glied nicht durch ein Suffix erweitert ist: рогодел, головохоп. Am häufigsten bedient er sich der Suffixe -ец und -тель z.B. in браздодерхеи, бегоборец, конеборец, луконосец. земледерхатель, горожитель, птицегадатель, фимиамогадатель, питорушитель. Sehr selten verwendet er das Suffix - йа: aproубинца, людоубинца. In дальноземец dagegen bezeichnet das Suffix -ец die Herkunft, in пятизубеи einen Gegenstand mit einer charakteristischen Eigenschaft. Von den Imperativkomposita mit regierendem Vorderglied vom Tyр дерилюд, скалозуб macht Gnedil keinen Gebrauch.

\section{Ad jektiva}

Die weitaus umfangreichste hompositionsgruppe bilden die Adjektiva, und hier sind wiederum besonders produktiv die für

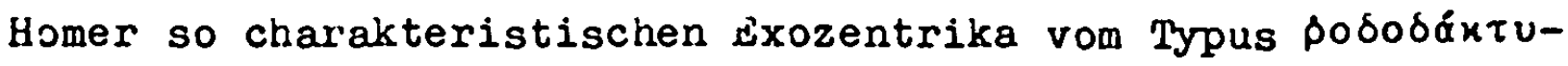

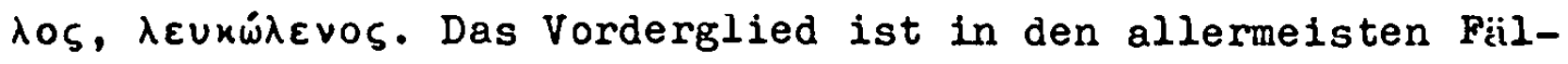
len ein Adjektiv, z.B.in белоклыкин, высоковолосын, внсоковершинның, гордовынны, крутовынны, дебелокопытныи, длиннотенны, долголезвенны, лепотронны, высокочубасты, широкочелисты;

selten ein Substantiv, z.В.іn бранодушныи, ветроногия, волоокий, волокохныи, пуговерхић;

manchmal ein Zahlwort, z.B.in двулезвеннын, двуяремнын, обордувесельныи, семивратныи, стоскамеиныи.

Nicht so zahlreich vertreten wie die Exozentrika, aber doch umfangreich ist die Gruppe der Adjektiva mit verbalem Charajter, z.В. бранолюбивын, добычелюбивын, дальнометкии, древорубны, душеснедның, рукометныи, палиценосны, копьеносны, руноносныи, празднобродныЯ. 
Ganz selten verwendet GnediC Adjektiva, die von Substantiven abgeleitet sind, die ihrerseits sc..on Ableitungen darstellen: копьеборственны, мухеубииственный.

Eine untergeordnete Rolle spielen ferner die sogen.DvandvaKomposita, wie z.B. багрянозлатистын, блистательногладкии, пламеннозарныи, дерзкоотважның, выпуклосветлии, мучительноострый, лесисто-холмисты .

\section{Partizipia}

Sehr zahlreich vertreten sind die Partizipia, darunter am zahlreichsten die Part.Präs.Aktiv, z.В. быст рольоиися, бурнолетаюии, златоблещущй, щлемоблещушии, звонкорокочу щий, щедропитающй, свирепогордящийя, злачноцветуший, грозногремящии U.v. $a$.

Hiiufig kommen auch Partizipia Prüt.Passiv vor, z.В. древлерожденный, красияоотесанный, красноопоясаниыи, прекрасновенчанныи, хитротканный, крепкозданный, худохносработанный. Ganz selten sind dagegen die Partizipia Prät.Aktiv und Prïs. Passiv: вьсоковздымавщиися, давнородтийя, новопришлий, полно оослин.

Alle von Gnedič geprägten partizipialen Komposita haben adjektivischen Charakter.

Bei näherer Betrachtung ergibt sich, daß der Dichter bei der Prägung dieser Komposita nicht von einem Infinitiv "высококрутиться, " урнолетать, *длемоплестеть, *красивоотесать, * красноопоясать, *щедропитать, "крепкоздать usw. ausgegangen ist, sondern die Partizipien unmittelbar gebildet hat. In den seltensten Fällen sind diese NK Lehnübersetzungen von Partizipien griechischer zusammengesetzter Verben, wie z.B. пымноблестяпии, яркоблестящи панфаро́шv übersetzen. In einigen wenigen Fällen steht bei homer ein durch einen Akkusativ des inneren Objekts näher bestimmtes Partizip, z.B. ent-

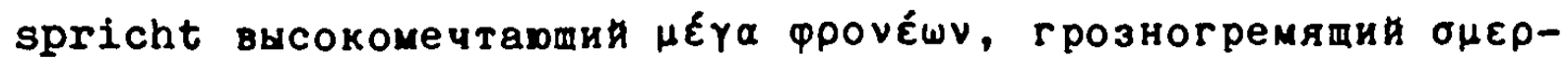

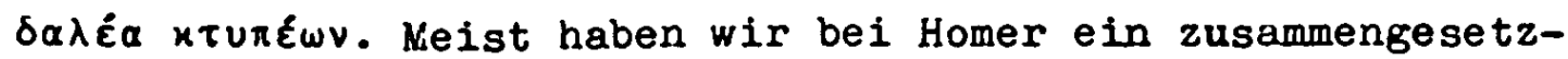
tes, einige Hale ein einfaches Adjektiv, z.B. übersetzt нe-

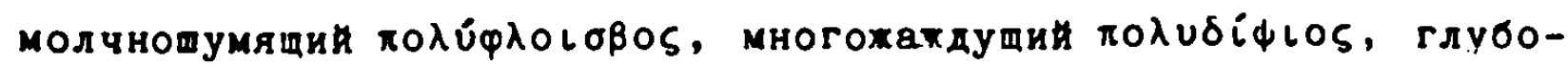

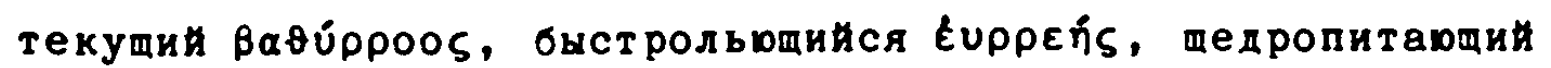

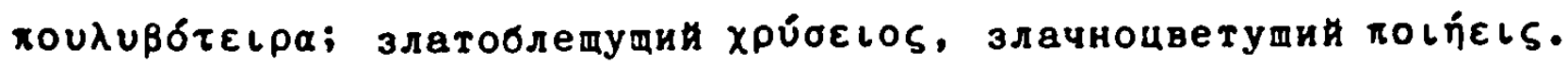


Vienn einem russischen $N K$ im griechischen Original ein Partizip entspricht, haben wir entweder keine Zusammensetzung:

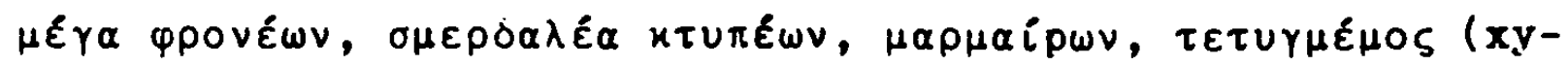
ложносработанның), oder die Zusammensetzung ist nur im Par-

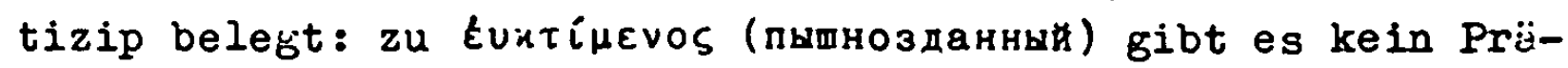

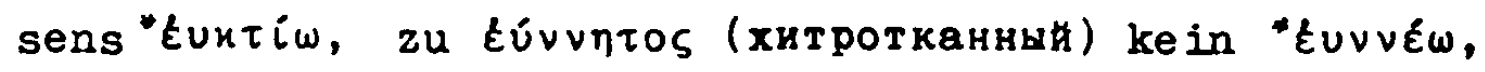

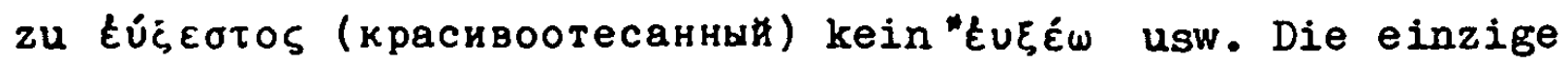
Ausnahme bildet $\pi \alpha \mu \varphi \alpha v o ́ \omega \nu, z u$ dem andere Verbformen existieren.

\section{Asyndeta}

Auf die Asyndeta wird in vorstehender Arbeit nicht näher eingegangen. Die verschiedenen Ausgaben der Iliäsübersetzung von Gnedid weichen stark voneinander ab. In der Ausgebe von 1956, die I.N. inedvedeva für die Библиотека поэта redigiert hat, kommt eine Unzahl von Asyndeta vor, z.B. Зевс-громовержец, Пизандр-воевода, Аполлон-небожитель, Гектор-мукеубиица, Атрид-царь, Гера-богияя, Ида-гора, аргивяне-герои .

In der Academia-Ausgabe von 1935 sind diese Verbindungen bis auf wenige Ausnahmen (z.В.сыны-близнецы, друг-возница, сподвикник-возница, дева-младенец, браздодеркец-клеветр) getrennt geschrieben. Das gesicherte Material ist so geriag, daß man nicht darauf aufbauen kann. Es ist nicht genau auszumachen, ob determinativ bestimmtes Зевс-громовержец bеzw. Зевс громовержец usw. als enge asyndetische oder als losere appositionelle Verbindungen aufzufassen sind. Soviel steht allerdings fest: es fehlen die in der Volksdichtung so gelüufigen Dvandva-Asyndeta vom Typ далекощироко, die iterativen Asyndeta vom Typ душенька-дупа und die im Mirchen beliebten possessiven Verbindungen vom Typ тур-золотые рога. Sie hätten in der feierlichen Sprache der Iliasübersetzung von Gnedid als Fremakörper gewirkt. 
Der vorherrschende Eindruck, den man von der Sprache der Ilias Gnedil gewinnt, ist der einer gewissen Feierlichkeit. Gemäß seiner Auffassung, daß die Sprache der Ilias schon für die Griechen der klassischen Epoche archaisch war, war Gnedið bestrebt, seiner Ubersetzung einen altertümlichen Charakter $z u$ verleihen. Im Vorwort zu seiner Iliasübersetzung bezeichnet er простота и сила..., торжественная вахность, величавая простота, важное спокойтвие als wesentliche Züge der Ilias. Dementsprechend ist seine Ubersetzung mit altrussischen und vor allem kirchenslavischen Wörtern durchsetzt, z.В. телом, доспех, выя, рамо, ланита, десница, шуйua, дшерь, глаголать, он рек u.v.a. Selbst der Dativus absolutus kommt vor. Doch fehlen auch Ausdrücke aus der Volkssprache und Dialektausdrücke nicht, sogar Ukrainismen finden sich. 1) Alle diese verschiedenen Elemente entsprechen den verschiedenen Schichten des Originals. Sie verschmelzen ineinander und verden zu einer Einheit. Gnedid wollte den Leser aus seinem gewohnten sprachlicren ililieu herausheben, ihm zeigen, daß er mit Homer etwas genz Ungewöhnliches, Erhabenes vor sich hat, er wollte den Leser zu Homer emporheben, nicht Homer dem Leser anpassen. 2) ir selbst schreibt im Vorwort zu seiner Iliasübersetzuing: "Чтобы сохранить своиства сии поэзии древнеи, столь вооэше противоположные тому, чего мы от наших позтов требуем, переводчику Гомера долхно отречься от раболепства перед вкусом гостинш, перед сеЙ прихотливоИ утонченностьо и изнеженностьо обществ, которых одобрения мы робко ищем, но коих требования и взыскательность связнвают, обессиливарт язык." 3 )

ias die NK betrifft, so verwendete er einerseits solche, die, aus dem Kirchenslavischen stammend oder zum mindesten von ihm beeinfluBt, schon vor ihm gebrüuchlich waren, z.В. благо-

1.Vgl.I.I.Tolstoj a.a.0.S.101 ff, kukulevic a.a.0.S.37 rf, 55 ff, Jegunov S.266 ff, Medvedeva a.a.0.S.29 ff. 2.VGI.Jegunov S.71.

3.Zit.nach H.I.GnediC, Stichotvorenija, Biblioteka poeta, leningrad 1356. 
душныи, благотворнын, велелепный, велемудрый, густобрадыи, душевредны , черновласы, ясноглагливы U.v.a. Andererseits bildete er aus kirchenslav. Bestandteilen neue Komposita: благодумныи, глубобразды, браздодержед, бранодушның, стоградның, румяноланитын, гордовыннын, златобразды, златотронның, многозлатын, кудревласын, кудреглавын, лиленнораменнын, шлемоблещущй u.v.a.

Es fehlen aber auch nicht solche NK, die in der Volksdichtung beliebt sind: златокрылын, белокаменны, быстрокрылын, злосчастныи, круторогй, рукопашның . хлебородныи, черногривы u.a. Alle diese in der Volkspoesie so geläufigen Adjektiva sind aber mehr oder weniger vom Birchenslavischen und letzten Endes vom Griechischen beeinfluBt, wenn man es innen auch nicht auf den ersten Blick ansieht. 


\section{Schlußwort}

Zusammenfassend läßt sich folgendes sagen:

Selbstverstündlich hatte Gnedil für die Bildung seiner Nominalkomposita viele Vorbilder, unter deren Einwirkung er bevrußt oder unbewußt stand, angefangen von den griechisci beeinfluBten kirchenslavischen und altrussiscien Komposita literariscicer oder volkstümlicher Prägung über die Barockdichtung bis zu Deržavin, der unter dem Einfluß der deutschen Dichtung stand ${ }^{1)}$, und zu VOB. Mit Sicherkeit bat GnediX neben der Iliasübersetzung von Kostrov die von Jekimov (1776) gekannt und aus beiden mancres ipitneton übernommen, z.B. бурноногии, броненосныи, многотравныи, среброногии. Er hätte sich die Arbeit wesentlich leichter mac:en und bedeutend mear iJK übernekmen können, z.B.aus Jekimov бarpяноперстнй, волногремящй, краснотекущй, лученосныи, пагубоносның, конопитательныи, скороногии, хитроковарнын, кповоненасытнии, кровопивственныи, градосотрясатель и.а. ${ }^{2}$ )

Von Kostrov hätte er entlehnen können: леполанитныи, белораменныи, людоплодньи, многолиственни, многогубныи, волносекущй (корабль), груборечивьи, сугубодонныи, облаконосец, лепоокин, голубоокин, лепообразнын, пагубоносни и.а. 3 ) Sehr zweifelhaft ist es, ob er die nomerübersetzungen von Kondratovic und diartynov kannte. ${ }^{4}$ ) Sie scheiden also wohl als Vorbilder aus. Namentlich von ersterem hätte er eine i.lenge Epitbeta übernehmen können. 5)

Auch in anderen quellen finden sich Komposita, die gut in seine Ubersetzung gepaßt hätten, z.B., um nur einis̆ :/enige zu nennen, bei Deržavin: румянощекии, сладкозвучның, in den Пандекты Никона Черногорна: облакогонитель, in der Кормчая книга Ефремовская (Тр.л.): облакопрогоньникъ, vgi.Srez., in

1.Vgl.Kukulevit a.a.0.S.10, 21, Jegunov S.167.

2.Vgl.Jegunov $\mathrm{S} .59$.

3. Derselbe 5.95 f.

4.Derselbe $5.49,330$.

5.Z.В.багряноризнын, шафрановиднын, сероглазыи, облакособиратедьныи, медноосновательны , собакоглазы , красивогривый, шлемодвихный, племодвихник, марсоподобный, боговоскормленны, боговоспитанныи, плотнокопытный, vgl.Jegu nov S.47. 
Slov.Ak.Ross.1822: птицеволхвователь.

Gnedið zog es aber in vielen Fällen vor, seine eigenen NK zu prägen, sei es, daß Gründe des Versmaßes, des Wohllauts oder des persönlichen Geschmacks maßgebend waren, oder daß ihn die Freude am dichteriscren Schaffen dazu veranlaßte. Nicht beeinfluBt wurde Gnedit in der Bildung seiner INK von den tbersetzungen von lime Dacier, Bitaubé u.a., da die homerische synthetische Art der Komposition der Struktur des Französischen fremd ist. Auch die tbersetzung von Pope, die Gnedic nur durch Vermittlung einer französischen tbertragung kannte, mußte auf die Komposition Gnedic ohne Virkung bleiben. Unbekannt war ihm die Homerübersetzung von George Chapman. die reich an NK ist. 1)

Wenn auch von der Liste der vor Gnedil nicht belegten wK ( $B$ II 2a,b) durch weitere Untersuchungen einige zu streichen sein werden, so bleibt doch eine stattliche Reibe von iveologismen übrig, die Gnedit sicher selbst gebildet hat. Wichtig ist die Tatsache, daß er nicht nur eine Menge NK als Lehnübersetzungen geschaffen, sondern sogar eine beachtliche Zahl von Komposita ohne genaues Vorbild bei Homer geprägt kat. lian darf wohl sogar annehmen, daß Gnedic kraft seiner dichterischen Sprachgewalt manches $\mathrm{NK}$, das vor ihm nachweisbar ist, auch ohne Vorbild selbständig genau so gebildet hïtte. Mopexодныи z.B.ist schon vor Gnedic üblich. Er hiitte

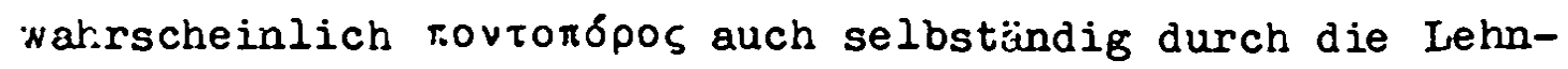
übersetzung мореходны wiedergegeben. Das gleiche dürfte

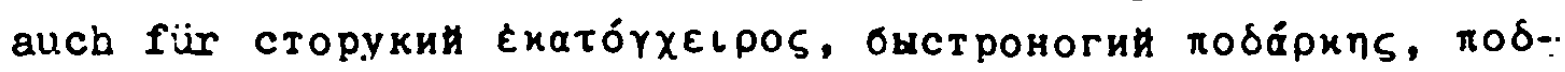

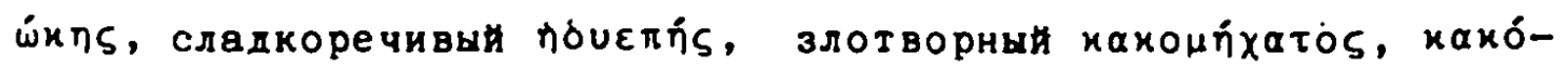

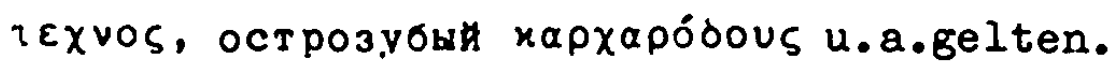

Gleichgültig, ob Gnedil ein NK mehr oder weniger geprägt bat, auf jeden Fall hat er sowohl mit seinen iN als auch mit seiner ganzen Iliasübersetzung eine gevaltige sprachschöpfe-

1. Bei ihm finden sich: man-slaughtering, sweet-spoken, divers-langueged ( $1 \varepsilon \rho \mathcal{L})$, cloud-gatherer, the bleckcloud-gathering Jove, rosy-fingered, silver-footed, wite-armed, ivory-wristed, both-foot-nalting । \& $\mu \varphi$ ruńl(s), the swift-foot, god-like son of Thetis, Thou subject-eating king u.v.a. 
rische Leistung vollbracht. Allerdings brachten manche seiner Zeitgenossen seinem Schaffen wenig Verständnis entgegen, sie lehnten seinen feierlichen Stil, vor allem die kirchenslavischen Elemente und die NK ab. So verwarfen nicht nur die Karamzinisten, sondern sogar Šiłkov die spitheta. 1) Positiv dagegen äußerten sich vor allem Puskin, der selbst bei der Bildung seiner Epitheta von GnediC beeinfluBt ist, ${ }^{2}$ und Belinskij.3) Aber Gnedic wollte und konnte auf diese stilmittel nicht verzichten, er wollte Homer den Lesern nicht durch allerlei Zugeständnisse an den Zeitgeschmack nëherbringen, sondern den Leser bewuBt zu Homer emporheben. Hie kein zweiter hat er die Ilias mit dichterischer Kraft ins Russische übersetzt. Zu einer dichterischen Ubersetzung gehören aber unbedingt die Nominalkomposita, ohne diese Epitheta wäre Homer nicht das, was er ist. Trotz gewisser Freiheiten ist es Gnedit gelungen, in die Geheimnisse des Stils Homers einzudringen, den Geist der Ilias ins Russische zu übertragen.

1.Vgl.Jegunov S.96.

2.Vgl.Kukulevid a.a.0.S.11, Jegunov S.134.

3. Vgl.Jegunov S.294. 


\section{Nachwort}

Die Anregung zu diesem Thema verdanke ich tierm Professor Dr.Wilhelm Lettenbauer. Für seine Anteilnahme an der Arbeit und wertvolle tinweise spreche ich inm meinen aufichtigen Dank aus.

Ferner danke ich herzlich meinem Studienkollegen, Herrn Dr. Helmut Schaller, der mir bei der Beschaffung wichtiger quellen sowie bei der Anfertigung des Typoskripts behilflich war.

Hein besonderer Dank gilt Herrn Professor Dr.Alois Schmaus und dem Verlag Otto Sagner für die Veröffentlichung der Arbeit innerhalb der "Slavistischen Beiträge".

Bayreuth, im Dezember 1968 